\title{
PAULO LOPES
}

Estudo do desenvolvimento da escuta melódica de adultos integrados a coros vocacionais

\section{UNIVERSIDADE DE SÃO PAULO}

Escola de Comunicação e Artes

São Paulo

2010 
PAULO LOPES

\section{Estudo do desenvolvimento da escuta melódica de adultos integrados a coros vocacionais}

Dissertação apresentada a Escola de Comunicação e Artes da Universidade de São Paulo para obtenção do título Mestre em Artes

Área de Concentração:

Técnicas Composicionais e Interpretativas

Orientador: Prof. Dr. Marco Antonio da Silva Ramos

São Paulo 


\section{Autorizo a reprodução e divulgação total ou parcial deste trabalho, por qualquer meio convencional ou eletrônico, para fins de estudo e pesquisa, desde que citada a fonte.}

Catalogação na Publicação

Escola de Comunicações e Artes da Universidade de São Paulo

Lopes, Paulo

Estudo do desenvolvimento da escuta melódica de adultos integrados a coros vocacionais / Paulo Lopes. - - São Paulo : P. Lopes, 2010.

136 p. + anexos

Dissertação (Mestrado) - Departamento de Música/Escola de Comunicações e Artes/USP.

Orientador: Prof. Dr. Marco Antonio da Silva Ramos

Bibliografia

1. Escuta melódica 2. Regência coral 3. Canto coral 4. Percepção musical 5. Técnica de ensaio

6. Afinação coral 7. Educação musical 8. Didática da afinação coral I. Ramos, Marco Antonio da Silva. II. Título.

CDD 21.ed. -780 
Nome: LOPES, Paulo

Título: Estudo do desenvolvimento da escuta melódica de adultos integrados a coros vocacionais

Dissertação apresentada à Escola de

Comunicação e Artes da

Universidade de São Paulo para

obtenção do título Mestre em Artes

Aprovado em:

Banca Examinadora

Prof. Dr. Instituição:

Julgamento: Assinatura:

Prof. Dr. Instituição:

Julgamento: Assinatura:

Prof. Dr. Instituição:

Julgamento: Assinatura: 


\section{DEDICATÓRIA}

Dedico este trabalho a Elias Lopes (in memorian) 


\section{AGRADECIMENTOS}

Ao Prof. Dr. Marco Antonio da Silva Ramos orientador, amigo e inspirador de meu trabalho na área do Canto Coral, responsável por esse grande organismo musical que é o Comunicantus: Laboratório Coral que é modelo para os coros em todo o país, e pelos seus trabalhos que foram de importância fundamental para a concretização da presente dissertação.

À Prof. ${ }^{a}$ Ms. Susana Cecília Igayara minha orientadora na graduação e que por diversas vezes assumiu esse papel indiretamente durante a realização deste trabalho, e me ensinou muito sobre música.

Aos meus Pais: Francisco Lopes e Maria Amélia Lopes por terem me educado com amor e honestidade que guiando meus passos até aqui.

Sula Andressa Engelmann minha companheira que trouxe tanta alegria aos momentos mais difíceis que passei ao longo da realização deste trabalho.

A Prof. Ms. Andréia Anhezini minha amiga e colega de trabalho na UEM por ter me compreendido e ajudado durante período do meu mestrado.

Ao Prof. Dr. Edelton Gloeden que está sempre em meu caminho contribuindo generosamente para minha evolução profissional.

Ao Prof. Ms. Paulo Rubens Morais Costa pelo seu magnífico trabalho de mestrado que serve como referencia para meu trabalho na área de canto Coral.

A Prof. ${ }^{a}$ Dra. Jane Borges que desde meu período de graduação faz observações pertinentes a respeito de meu trabalho.

Ao Prof. Dr. Pedro Paulo Salles por ter ampliado meus horizontes na área Educação Musical de maneira tão rica.

Ao Prof. John Kennedy Pereira de Castro companheiro das disciplinas e das idas e vindas do nosso caminho para o mestrado.

À Brigite Teichrieb de Castro pela valiosa contribuição para a formatação deste trabalho.

À Marcio Ocon meu grande amigo desde os tempos de graduação, que contribuiu com as longas conversas e reflexões que fizemos a respeito do trabalho com o Coral Oficina Comunicantus, no participou efetivamente somando aos resultados deste trabalho.

Aos meus colegas: Anselmo Mancini, Caiti Hauck, Filipe dos Santos, Isaac Terceros, Mariana Pilotto, Renato Spinosa e Rodrigo Báez que contribuíram enormemente para a realização deste trabalho com suas avaliações e atuações tão preciosas junto ao Coral Oficina Comunicantus. 
Aos demais integrantes do Comunicantus: Laboratório Coral que também contribuíram com os resultados desta dissertação.

Juan Pablo Garcia Lopes pela amizade e compreensão em tantos momentos difíceis nos quais precisei de um ouvido amigo e de tantos outros mais fáceis e que você foi meu irmão de coração.

Aos meus mais recentes amigos os professores e pianistas Adriano Gado, Ticiano Biancolino e Yuri Pingo, co-participantes de tantas discussões e questionamentos sobre música e ensino que contribuíram enormemente para minhas reflexões.

A todos os coralistas que cantaram no Coral Oficina Comunicantus, que foram fonte da inspiração e do trabalho desenvolvido em minha dissertação.

A todos os coralistas integrados aos grupos Coral Infanto-Juvenil do DMU-CAP e Oficina Coral da UEM, com os quais aprendi muito na maneira como trabalhar com canto coral e educação.

Aos Souza: Eusébio, Maria de Fátima, Vivian e Wesley que tanto me apoiaram e acolheram durante o período em desenvolvi este trabalho.

À Escola de Comunicação e Artes, pela oportunidade de realização do curso de mestrado.

À Universidade Estadual de Maringá onde leciono, que possibilitou tantas vezes que eu viajasse para fazer meu mestrado.

A todos aqueles que de alguma forma contribuíram com este trabalho e não mencionei meu muito obrigado. 


\section{RESUMO}

\section{LOPES, Paulo. Estudo do desenvolvimento da escuta melódica de adultos integrados a}

coros vocacionais. 2010. 136 + anexos f. Dissertação (Mestrado) - Escola de Comunicação e Artes, Universidade de São Paulo, São Paulo, 2010.

O objetivo principal deste trabalho é estudar os processos de desenvolvimento da escuta melódica de adultos, sem formação musical, integrados a coros vocacionais, com o intuito de poder melhorar a performance vocal do grupo. Tendo como objeto o processo de formação do Coral Oficina Comunicantus, grupo integrado ao Comunicantus: Laboratório Coral do Departamento de Música da Escola de Comunicações e Artes da Universidade de São Paulo. Nosso método de coleta de dados foi baseado nas observações dos ensaios e nas análises das avaliações (relatórios) feitas pelos monitores integrados ao Comunicantus: Laboratório Coral, através dos quais procuramos vislumbrar as necessidades de aprendizagem dos coralistas do coro supracitado. Por se tratar de uma pesquisa ora de observação ora interativa, atuamos combinando tais ações e orientando o desenvolvimento das habilidades inerentes à escuta melódica em aspectos pré-definidos. Durante o processo investigativo, utilizamos como método referencial de análise, dos conteúdos musicais, os trabalhos do Prof. Dr. Marco Antonio da Silva Ramos e do Prof. Paulo Rubens Morais Costa e, por outro lado, a produção bibliográfica de educadores como César Coll e Teresa Mauri, que atuaram na reforma escolar espanhola, de forma a subsidiar nossas escolhas pedagógicas e didáticas para atuar junto aos coralistas. Como resultado desse processo, pudemos desenvolver algumas atividades que contribuíram para a resolução de certas necessidades de aprendizagem momentâneas deste grupo e também suscitaram a criação de outras que foram utilizadas oportunamente, após o término do prazo definido de observação e interação a que este trabalho se refere.

Palavras-chave: escuta melódica, regência coral, canto coral, percepção musical, técnica de ensaio, afinação coral, canto coral e educação musical, didática da afinação coral. 


\begin{abstract}
LOPES, Paulo. Study about the processes of development of melodic hearing by adult choral amateur singers. 2010. 136 + anexos f. Dissertação (Mestrado) - Escola de Comunicação e Artes, Universidade de São Paulo, São Paulo, 2010.
\end{abstract}

This dissertation aims mainly at studying the processes of development of melodic hearing by adults who do not have any musical formation and yet join vocational choirs in order to improve the vocal performance of the group. Its object is the process of formation of the Educational Lab-Choir Comunicantus, which belongs to the Comunicantus Choral Office of the Department of Music of the School of Communication and Arts of the University of São Paulo. The method of data collection was based on rehearsal observations and on the analysis of evaluations (reports) made by student trainees integrated in the Comunicantus Choir Office, through which we trie to identify the gaps in learning of the choir singers. As the research is partly made up of observations and partly interactive, action was taken so as to combine these actions and give advice on the development of skills innate to melodic hearing in predefined aspects. Along the process of investigation, the Referencial de Análises of the musical contents by Professor D. Marco Antonio da Silva Ramos and Professor Paulo Rubens Morais Costa were used as a method. On the other hand, the works by educators as César Coll and Teresa Mauri, who worked in the Spanish school reform, were used to provide pedagogical and didactic choices for us to act with the choral singers. As a result of this process, some activities were developed that contributed to offer solution to some specific learning needs of this group and also made possible the creation of others that were used, whenever suitable, after the period of observation and interaction.

Key-words: melodic hearing, choral conducting, choral singing, ear training, rehearsal techniques, choral tuning and musical education, didactic of choral tuning. 


\section{SUMÁRIO}

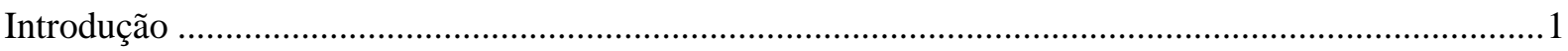

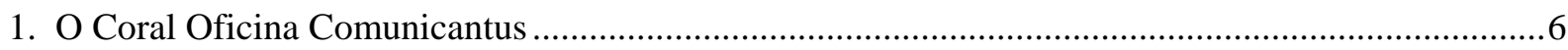

1.1. Perfil das pessoas que procuram os coros vocacionais...........................................................6

1.2. Nossa postura como regente/educador frente ao Coral Oficina Comunicantus ...........................8

2. Dificuldades apresentadas pelo coro e conseqüentes conteúdos a serem trabalhados ......................13

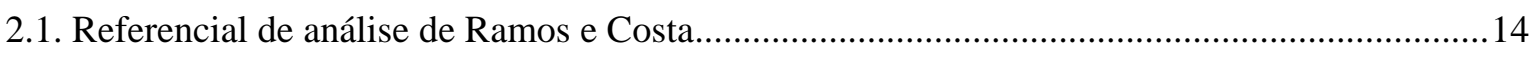

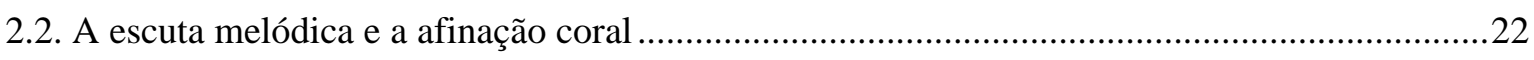

2.3. Escolha do repertório e tipologia dos conteúdos de ensino-aprendizagem que serão

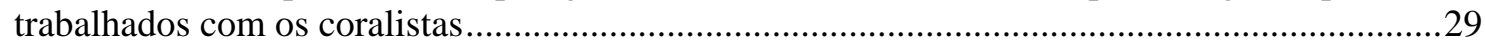

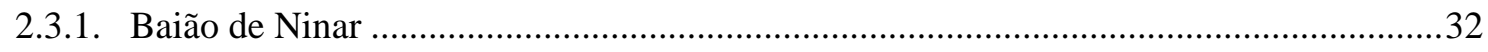

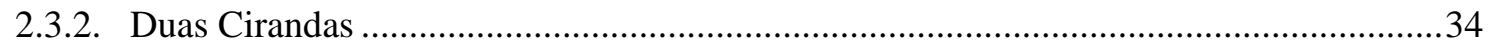

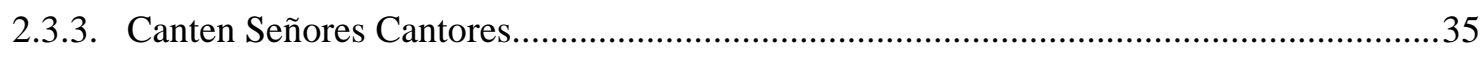

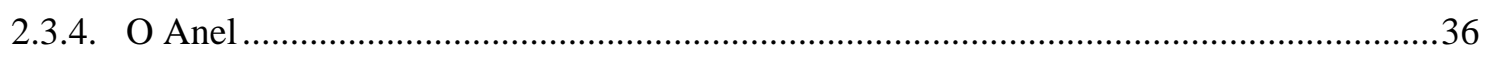

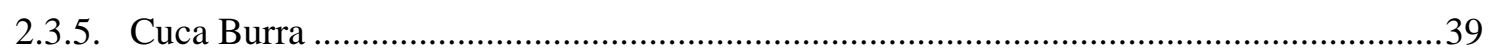

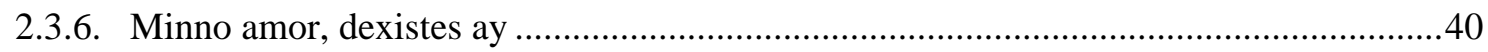

2.3.7. Tres Morillas m’enamoram.............................................................................................

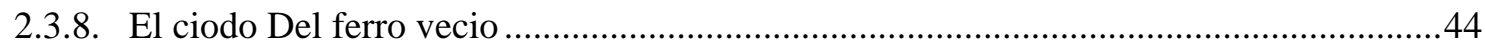

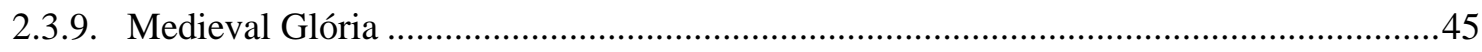

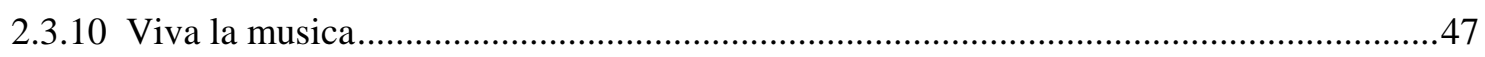

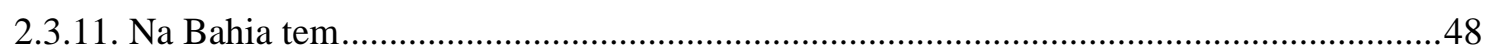

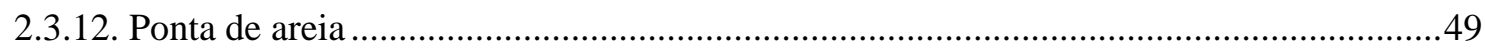

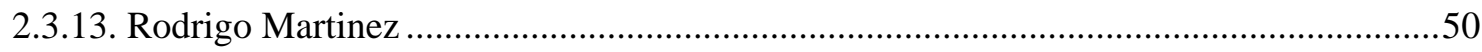

3. Relatórios de Avaliação de Ensaio do Coral Oficina Comunicantus ..................................................53

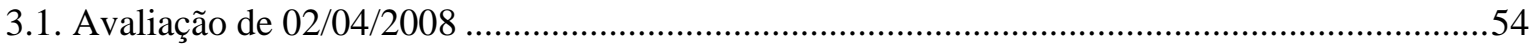

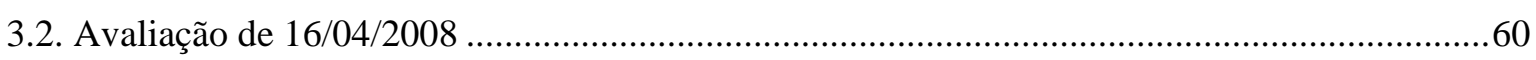

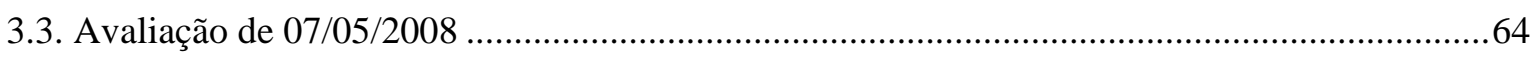

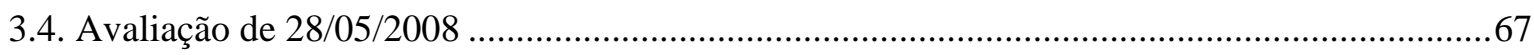

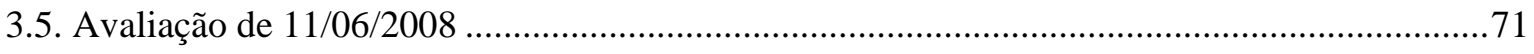

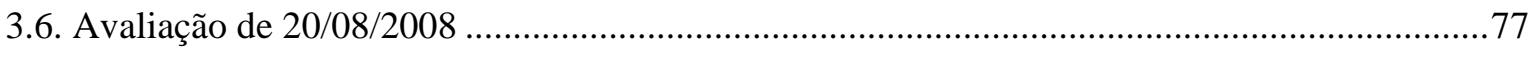

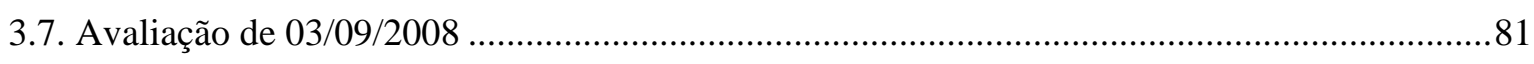

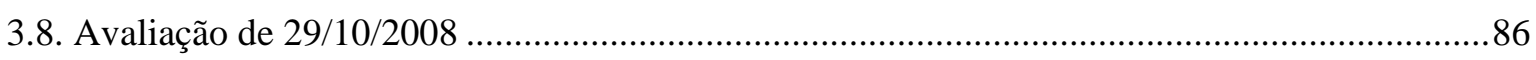

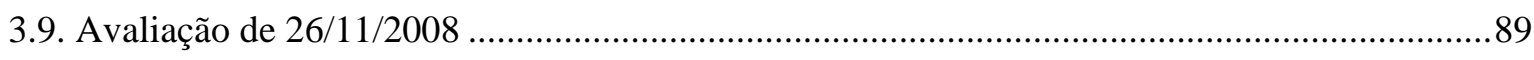

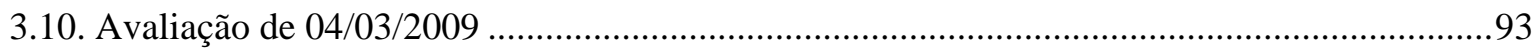


3.11. Avaliação de 25/03/2009 ......................................................................................................98

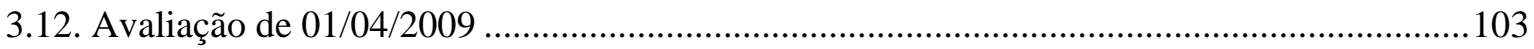

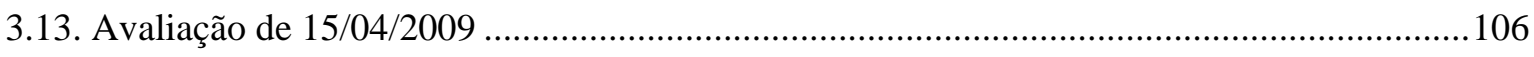

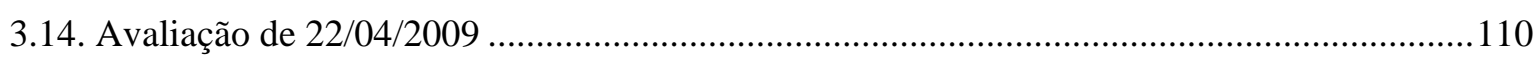

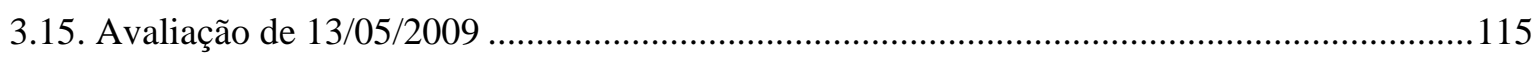

4. Desenvolvimento de atividades pedagógicas com o objetivo de construir a escuta melódica.........119

4.1. Apresentações de atividades pedagógicas ..............................................................................119

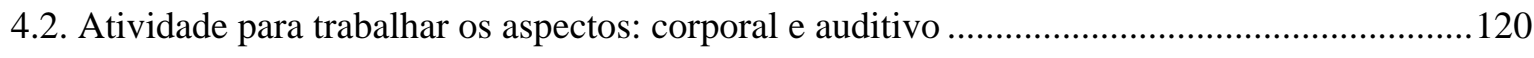

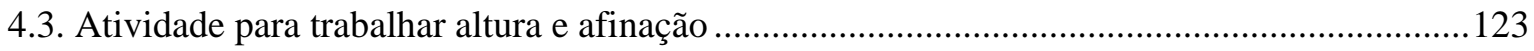

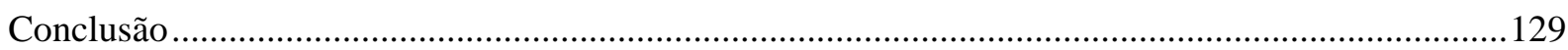

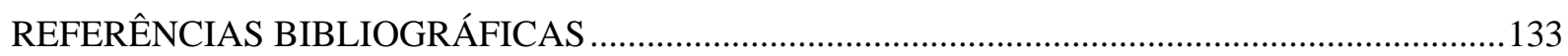

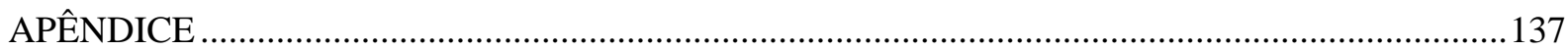

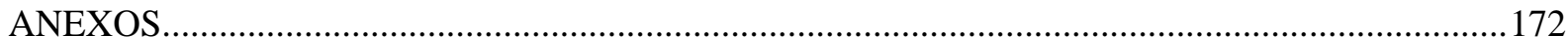




\section{INTRODUÇÃO}

\section{Problemática do desenvolvimento da escuta melódica de adultos sem formação musical elementar}

A idéia de realizar uma pesquisa sobre o Canto Coral e os diversos aspectos relacionados a seu desenvolvimento e execução vem amadurecendo desde que comecei a trabalhar como monitor Comunicantus:Laboratório Coral. Durante este tempo (de abril de 2003 até dezembro de 2006), pude observar os diversos trabalhos realizados e os resultados obtidos, demonstrados de forma concreta pelo desenvolvimento dos coralistas e sua constante evolução a cada ensaio e apresentação. Na condição de monitor e de aluno regente, acompanhei os procedimentos de abordagem em percepção auditiva, percepção rítmica, escuta melódico/harmônica que ocorriam dentro de um processo amplo, interdisciplinar e integrado, que unia educação musical, técnica vocal e performance coral. Tal processo resultava nas apresentações públicas que eram um fator preponderante, tanto para a motivação dos integrantes dos coros quanto para a evolução nos aspectos musicais.

A ligação direta entre musicalização e performance foi se explicitando no âmbito do Comunicantus: Laboratório Coral de forma inequívoca e foram se firmando em meu aprendizado e reflexão sobre Educação Musical enquanto aluno da graduação no curso de Licenciatura no Departamento de Música da ECA-USP, motivando a temática de meu Trabalho de Conclusão de Curso e o traçado desta dissertação.

O objetivo principal deste trabalho é estudar os processos do desenvolvimento da escuta melódica de adultos sem formação musical que estão integrados a coros vocacionais ou amadores, com o intuito de poder melhorar a performance vocal do grupo. Para desenvolver nossa investigação, observarmos o processo de formação do Coral Oficina Comunicantus, grupo integrado ao Comunicantus: Laboratório Coral do Departamento de Música da Escola de Comunicações e Artes da Universidade de São Paulo. Veremos descrição mais detalhada sobre o grupo estudado no item do primeiro capítulo: Perfil das pessoas que procuram que o Coral Oficina Comunicantus.

Como mencionado anteriormente, em meu trabalho de Conclusão de Curso fiz uma pesquisa que me direcionou para o aspecto da problemática da performance em Canto Coral. Durante sua realização, sob orientação da Prof. ${ }^{a}$ Susana Cecília Igayara abordei diversos 
aspectos da realização musical com adultos integrados ao Coral Escola Comunicantus ${ }^{1}$, e tal experiência me estimulou a estudar mais detalhadamente os aspectos que envolvem a aprendizagem de adultos, para utilização em questões do ambiente coral.

A partir das constatações que fizemos em nosso primeiro trabalho e das leituras de materiais musicais, educacionais, pedagógicos, didáticos e de técnica de regência coral, escolhemos enveredar nossa investigação pelo campo da escuta melódica dos coralistas sem formação musical elementar, para tentar entender melhor sobre as abordagens necessárias para conseguir bons resultados musicais com esta modalidade de coro.

Desenvolver a escuta melódica deste tipo de coro específico é uma questão que envolve múltiplas habilidades por parte do regente, do educador, ou do regente educador, termo que irei empregar neste trabalho por perceber que existem relações históricas entre estas duas funções dentro de diversos trabalhos na área do canto coral.

Cito como referência de tais trabalhos o do Prof. Dr. Marco Antonio da Silva Ramos, professor de Regência Coral na Universidade de São Paulo, a frente do Coral do Museu Lasar Segall, na cidade de São Paulo, um dos projetos mais bem sucedidos e com material pedagógico mais completo e efetivo dos quais tive acesso.

Toda a metodologia do seu trabalho, bem como o modelo, o pensamento pedagógico, os procedimentos didáticos e a maneira de funcionamento deste projeto junto ao Coral do Museu Lasar Segall estão registrados em sua dissertação de mestrado intitulada o Canto Coral: do repertório temático à construção do programa, de 1988. Com bases pedagógicas semelhantes às utilizadas no período em que atuou frente a coro citado imediatamente acima, continuou seu trabalho e criou o Comunicantus: Laboratório Coral na ECA-USP, que hoje engloba em seu corpo cincos coros que atingem coralistas de perfis variados, são eles: Coral da ECA-USP (alunos de graduação em música da USP e de outras habilitações da própria universidade), Coral Escola Comunicantus (alunos e ex-alunos da USP sem uma formação musical elementar e com idade entre 18 e 50 anos), Coral Oficina Comunicantus (alunos de graduação de diversas áreas da USP e funcionários sem formação musical elementar e com idade entre 17 e 30 anos), Coral da Terceira Idade da USP (núcleo da Terceira idade da USP idealizado por Ecléa Bosi) e Studio Coral Vozes Femininas (coro feminino de alta performance composto por alunas de graduação e pós-graduação em música).

Não é nosso objetivo criar um método de trabalho voltado para auxiliar regentes desta modalidade de coros, mas apenas relatar nossa experiência com um grupo que tem

\footnotetext{
${ }^{1}$ Um dos cinco integrados ao Comunicantus: Laboratório Coral.
} 
características tão comuns a muitos outros grupos corais em todo o país, e registrar as questões que envolvem os aspectos para a construção da escuta melódica deste grupo e das atividades desenvolvidas para ajudar a solucionar suas necessidades de aprendizagem. Para tal utilizaremos como metodologia um molde híbrido de pesquisa-ação e Estudo de Acompanhamento, no sentido dado a eles por Maria Amélia Santoro Franco (pesquisa-ação) e Kleide Ferreira do Amaral (Estudo de Acompanhamento). Esta combinação é devido ao fato que em determinados momentos estaremos pesquisando e interagindo com os coralistas com procedimentos flexíveis; ajustando-os progressivamente aos acontecimentos; estabelecendo uma comunicação sistemática com os integrantes do coro e a equipe de monitores; fazendo reflexões e auto-avaliações a respeito de todo processo investigativo, mas também, em outros estaremos apenas analisando paralelamente os métodos de trabalho dos alunos regentes, seus procedimentos didáticos, suas escolhas técnicas para resolução de questões musicais e seus resultados junto ao coro.

Ao longo de minha formação musical, estudei várias metodologias de ensino, algumas das quais foram de grande importância para a construção do meu pensamento enquanto regente/educador. Dentre minhas experiências cito como mais importantes para o

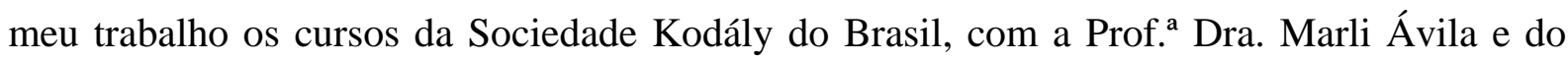
curso da Academia Internacional de Verano de Dirección Coral y Pedagogia Musica, em Las Palmas de Gran Canária (Espanha), com os professores Lilla Gábor (Hungria), Sandra Mathias(EUA), Janice Cusano(EUA) e Fernando Malvar-Ruiz (EUA/Espanha). Através de tais experiências conheci detalhadamente o trabalho de Zoltan Kodály, que não menciono diretamente, mas que aparece mais como uma inspiração geral do trabalho, criando um substrato sempre presente, mas nem sempre direto, citável e palpável na aplicabilidade de seus métodos e postulados à aprendizagem musical de adultos e orientação do desenvolvimento da percepção auditiva dos coralistas. Da mesma forma foram vistos trabalhos de Edgard Willems que tratam de aspectos psicológicos do ensino musical, utilizando a memória como elo ligação entre os aspectos necessários à aprendizagem e ao desenvolvimento da percepção auditiva.

A memória é, antes de tudo, um elemento de continuidade, sustenta a consciência da personalidade e é indispensável para o progresso. Na música é índice do Dom musical e desempenha um papel decisivo na polifonia e na harmonia. A audição interior, absoluta e relativa, é um fenômeno da memória. As distintas memórias podem colaborar, e a experiência comprova, que o lembrar, que depende do interesse, da atenção da concentração e vontade, é muito fiel quando apela à 
associação das idéias (EDGAR WILLEMS, 1978 apud SUZIGAN; SUZIGAN, 1986, p. 3)

Murray Schafer compareceu obrigatoriamente referenciando a forma de estruturar o pensamento para a elaboração de atividades e jogos, no que se refere à escuta melódica e a criatividade musical. Fizemos uma reflexão sobre os trabalhos de Duane S. Crowther (Teaching Choral Concepts), Robert L. Garretson (Conducting Choral Music) para a orientação do trabalho de regência enquanto recurso didático e a também para a solução dos problemas que surgem ao nos confrontarmos com as noções e conceitos a serem trabalhados. Como não há prática e reflexão sobre música que não passem pela Teoria Musical buscaremos um referencial atualizado e consistente nos trabalhos de Ralph Turek (The Elements of Music: Concepts and Applications), e também de Claude Abromont e Eugene de Motalambert (Teoria de Música: Um Guia).

No campo da compreensão dos processos de aprendizado musical na contemporaneidade, observando os aspectos sociais e cotidianos utilizarei os trabalhos de educadores como César Coll e Tereza Mauri, que atuaram na reforma curricular de ensino na Espanha, trazendo, na medida do necessário e do possível, tais reflexões para o campo do canto coral no cotidiano, como elemento de compreensão da escuta auditiva nos dias atuais e seus efeitos no processo de ensino aprendizagem voltado para a performance musical.

Mas como chave de nossas averiguações dos aspectos e conteúdos musicais que serão analisados, utilizarei os trabalhos de mestrado do Prof. Dr. Marco Antonio da Silva Ramos e do Prof. Paulo Rubens Morais Costa, abordados mais detalhadamente no item 2.1 do capitulo 2, intitulado: Referencial de análise de Ramos e Costa.

Este trabalho está estruturado em quatro capítulos que abordam de maneira sistematizada nossa investigação da seguinte forma:

No capítulo 1. O Coral Oficina Comunicantus fazemos: a descrição completa do perfil dos coralistas do Coral Oficina Comunicantus para a pontuação das características que formaram nosso objeto inicial de pesquisa. Abordamos também questões sobre como seria a nossa conduta frente a este grupo, pontuando a nossa e metodologia atitudinal diante deste perfil de grupo.

No capítulo 2. Dificuldades apresentadas pelo Coro e conseqüentes Conteúdos a serem trabalhados, faremos uma abordagem da tipologia dos conteúdos que abordamos durante a investigação diante das necessidades de aprendizagem demonstradas pelo coralistas com perfil do grupo objeto desse trabalho. No subitem Referencial de Análise de Ramos e 
Costa, abordaremos as questões pertinentes a utilização dos trabalhos Ramos e Costa como principal ferramenta de observação e detecção dos conteúdos e aspectos necessários ao desenvolvimento da escuta melódica dos coralistas de coro. Em A escuta melódica e a afinação coral, discutimos as relações que envolvem o desenvolvimento destes dois aspectos em nosso trabalho, e em Escolha do repertório e a tipologia dos conteúdos de ensino aprendizagem que serão trabalhados com os coralistas, fazemos uma reflexão sobre a escolha das peças do repertório ensaiado com coro durante o todo o processo investigativo, mediante os parâmetros do referencial de análise escolhido para este trabalho, pontuando os elementos iniciais a serem desenvolvidos com os integrantes do coro.

No capítulo 3. Relatórios de Avaliação do Ensaio do Coral Oficina, colocamos quinze avaliações feitas pelos monitores e alunos regentes do Comunicantus: Laboratório Coral, através dos quais descrevemos todo o processo de desenvolvimento das questões inerentes a escuta melódica dos coralistas do Coro Oficina Comunicantus, abordando os aspectos trabalhados através do crivo do referencial de Ramos e Costa. Analisamos ainda os procedimentos que adotamos nos ensaios e as soluções para as necessidades de aprendizagem que surgiram ao longo da investigação.

No capítulo 4. Desenvolvimento de atividades pedagógicas com objetivo de construir a escuta melódica, fazemos nos dois primeiros itens um relato de atividades trabalhadas com o coro que abordaram aspectos pertinentes ao desenvolvimento da escuta melódica de seus integrantes, com reflexões a partir do referencial de Costa e Ramos acerca dos conteúdos escolhidos para tal. Como apêndice Outras atividades desenvolvidas, listamos atividades elaboradas a partir das necessidades de aprendizagem do Coro Oficina Comunicantus, que tratam de assuntos relacionados ao desenvolvimento da escuta melódica de seus coralistas, com a pontuação dos conteúdos por elas abordados a partir do referencial escolhido para este trabalho. 


\section{O Coral Oficina Comunicantus}

O Coral Oficina Comunicantus foi idealizado a partir do Coral Escola Comunicantus, grupo que tem como objetivo principal trabalhar repertório coral com coralistas vocacionais de formação educacional e musical diversa com uma característica em comum: serem amantes da música coral.

\subsection{Perfil das pessoas que procuram o coro}

Este trabalho foi desenvolvido no ambiente do Coral Oficina Comunicantus, que é um dos coros integrados ao Laboratório Coral Comunicantus da ECA-USP, já citado neste trabalho. Trata-se de um coro que tem como uma de suas funções disponibilizar aos estudantes de diversas habilitações do Departamento de Música da ECA-USP (CMU) uma oportunidade de colocar em prática os conteúdos aprendidos em sala de aula dentro do ambiente coral, possibilitado pela criação de um grupo com perfil e características semelhantes aos quais irão trabalhar futuramente, e desta forma, aprender a enfrentar a realidade do trabalho com corais constituídos por pessoas adultas sem formação musical, os chamados coros vocacionais ou amadores, que em nosso país são ampla maioria. Segundo Ramos em sua dissertação de mestrado, os coros vocacionais podem ser formados com os seguintes perfis:

São coros escolares, institucionais, religiosos, de empresas, profissionais (estes muito raros em nossa realidade sócio-econômica, independentes, infantis, juvenis, adultos, de terceira idade, masculinos, femininos, mistos, sindicais, políticopartidários, comunitários, cada um com seu repertório, mas sempre um coro. ( RAMOS, 1988, pg. 2)

O Coral Oficina é formado basicamente por estudantes de graduação e funcionários da USP, que tem perfil de idade variando entre 17 e 30 anos sem formação musical específica, abrangendo desde pessoas sem nenhum conhecimento musical até outros que tocam instrumentos como violão e piano dentre outros, e que inclusive, já cantaram ou 
cantam em outros coros. Neste contexto as diferenças de formação de âmbito cultural, social e musical entre os integrantes influenciam diretamente a qualidade sonora do coro. É neste aspecto que iremos direcionar esta pesquisa, vamos procurar detectar os problemas que incidirem no aspecto melódico e os pertinentes a sua compreensão por parte dos integrantes do Coral Oficina Comunicantus e, a partir daí analisar cada questão, para então elaborar ferramentas para ajudar a desenvolver a escuta melódica e a qualidade da emissão vocal do coro, de forma que evolua em performance musical. O trabalho de pesquisa foi realizado entre o período de abril de 2008 a maio de 2009, tendo seu desenvolvimento documentado em avaliações desde seu início, que retratam todos os procedimentos de planejamento e atuação nos ensaios. Devido à grande quantidade de material produzido ao longo deste processo, optamos por utilizar apenas algumas dessas avaliações, com o intuito de permitir uma visão mais ampliada de todas as necessidades de aprendizagem apresentadas pelos coralistas e da escolha das abordagens de âmbito sistemático, didático e pedagógico/musical empregadas durante nossa investigação, que foram elaboradas com a intenção de ajudar a saná-las.

No capítulo Relatórios de Avaliação do Ensaio do Coral Oficina onde faço as análises dos procedimentos adotados durante os ensaios. Para o leitor ter maior nitidez, utilizarei tamanho de fonte e espaçamento diferenciados em relação ao padrão adotado para o restante do texto $^{2}$, deixando evidenciado onde estão os relatórios e, onde estão minhas análises.

Para melhor apreciação das atividades e dos exercícios contidos nesse trabalho, utilizarei figuras com exemplos musicais, e como esse também é um procedimento presente nos relatórios, para maior clareza elas não serão relacionadas em uma lista, mas dispostas ao longo do texto dinamizando a leitura.

Retomando o assunto relacionado ao perfil desses coralistas, outro ponto que é importante salientar é o fato de este grupo estar em um estado bastante particular, digo isso, pois foi pela primeira vez em minha experiência como aluno de graduação, que tive a oportunidade de integrar uma equipe que trabalharia na formação de um coro em seu processo embrionário, onde realizamos considerações que vão desde o perfil de formação musical dos coralistas até o sociológico, para que assim a escolha dos elementos de atuação pertinentes ao trabalho coral como: estratégias de ensaio, atividades pedagógicas e as soluções musicais adotadas fossem orientadas pelas necessidades de aprendizagem apresentadas pelos

\footnotetext{
${ }^{2}$ Recuo de 4,5 para margem esquerda e 3,5 para direita e fonte tamanho 11.
} 
integrantes do coro. Diante deste fato, tivemos a oportunidade de observar todos os aspectos relacionados à sua criação, onde o Professor Dr. Marco Antonio da Silva Ramos e a Professora Ms. Susana Cecília Igayara trouxeram para discussão junto ao grupo de alunos e bolsistas em estágio no Comunicantus: Laboratório Coral, todas as questões pertinentes à criação de um grupo coral, desde as mais básicas como por exemplo: a definição de perfil dos coralistas, a escolha do local de ensaio, a determinação da carga horária adequada para cada ensaio, status na grade curricular, estruturação do planejamento dos ensaios, escolha dos monitores que se interessaram por engajar-se neste projeto, distribuição de responsabilidades entre eles até mesmo as questões mais específicas como a escolha do repertório a ser adotado, a estratégia de preparação vocal e o desenvolvimento musical dos coralistas.

Desta forma, o perfil dos integrantes do Coral Oficina Comunicantus possibilitou que nosso trabalho abordasse pontos e aspectos musicais que provavelmente um coro mais experiente talvez não permitisse por causa de seu nível de desenvolvimento e amadurecimento musicais, elementos somente observáveis em grupos com características semelhantes ao aqui mencionado.

\subsection{Nossa postura como Regente/educador frente ao Coral Oficina Comunicantus}

Este trabalho está voltado para uma reflexão em torno de um tipo de coro que predomina na realidade do país: o coro vocacional ou amador. À frente desse tipo de grupo, hoje é bastante comum que seus regentes assumam um papel diferenciado frente a eles, que necessitam que este profissional não somente reja, mas que também atue como um educador musical.

Este tipo de atuação, embora tenha marcado presença historicamente no Brasil desde os tempos coloniais com os jesuítas, passou por muitas transformações, sendo possível encontrar menções específicas durante o Século XIX, mas principalmente durante todo o século XX. Há grande número de trabalhos, especialmente nas áreas de História e de Pedagogia, que analisam, discutem e relatam o período mais evidente desta relação entre educação preparatória para a música e canto coral, nos apontando a direção a ser tomada com relação à metodologia e os pontos a serem abordados, como por exemplo, no projeto de Villa-Lobos 
para o Canto Orfeônico, que assim apontava como principais conteúdos de aprendizagem a serem ensinados:

\begin{abstract}
Em primeiro lugar, reúne todos os elementos essenciais à verdadeira formação musical: - a iniciação segura do ritmo, a educação auditiva, a sensação perfeita dos acordes. E, mais tarde, o tirocínio da leitura, a compreensão e a familiaridade com as idéias melódicas e com os textos expressos pelos autores diversos e, por último, as sensações de ordem propriamente estética: - faculdade de emoção ante a beleza melódica ou ante a capacidade dinamogênica do ritmo. (VILLA-LOBOS, 1946, 910 p.)
\end{abstract}

Diversos trabalhos se desenvolveram ao longo do século passado apoiados nas diretrizes de Villa-Lobos, mas de certa forma sempre voltados para o trabalho crianças e adolescentes em idade escolar. Nosso olhar investigativo se baseará sobre um conjunto de referências bastante documentadas e com uma continuidade de pensamento que vem desde o fim dos anos 70, no caso o Coral do Museu Lasar Segall, que entre 1977 e 1997 criou para si um perfil de coro chamado na época de coro comunitário, que era voltado para pessoas sem uma formação musical elementar, e que desenvolveu um trabalho de equipe formado por quatro profissionais e um grupo de quatro estudantes de música, que trabalhavam no sentido de desenvolver o grupo de coralistas para obterem um melhor resultado nos aspectos musical e de performance vocal, a partir de um investimento no desenvolvimento da educação musical de cada coralista. Ali foi cunhado o termo e a idéia de um Coral Escola que foi posteriormente implantada, ampliada, implementada e trazida para as necessidades e formas de atuação do meio acadêmico universitário, dentro do Comunicantus: Laboratório Coral da ECA-USP.

Ramos (1988) em sua dissertação de mestrado diz: "Um coro real tem limitações e possibilidades reais”. E hoje cabe ao regente lidar com essas limitações de uma forma com que o resultado musical apareça efetiva e qualitativamente. Segundo Costa, também em sua dissertação de mestrado, que define como parte da atuação do regente coral os seguintes aspectos:

Se o regente coral puder se aproximar instrumentalmente deste coro real, e assim identificar suas características, suas qualidades e suas limitações, terá mais recursos para realizar as suas possibilidades (COSTA, 2005, pg. 1) 
A pesquisa de Costa foi desenvolvida com o objetivo de criar instrumentos e ferramentas que pudessem ajudar no desenvolvimento musical de coralistas integrados a coros vocacionais ou amadores, com uma abordagem sistêmica apoiada principalmente na criação de soluções e atividades de caráter rítmico. Nosso trabalho vai por outra direção, ele busca a resolução das necessidades de aprendizagem no campo da escuta melódica e dos conteúdos interligados a esta questão como altura, timbre, variação de intensidade do som dentre outros já citados. Esta reflexão de Costa acerca das dificuldades apresentadas por coralistas vocacionais vem sendo desenvolvida, como já citamos anteriormente, desde o final dos anos 70 no trabalho realizado junto ao Coral do Museu Lasar Segall, que era dirigido pelos mesmos professores citados, o Prof. ${ }^{\circ}$ Dr. Marco Antonio da Silva Ramos e Prof. ${ }^{\text {a }}$ M. Susana Cecília Igayara, auxiliados por uma equipe de monitores estudantes de música, da qual Costa também fazia parte. Quando ele fala sobre este trabalho acaba mostrando que já apontava para uma direção didática e pedagogicamente orientada:

O trabalho que realizávamos neste coro já trazia em sua essência uma perspectiva fortemente educacional, e orientava-se pra promover a ampliação dos conhecimentos musicais dos coralistas, e para desenvolver suas potencialidades (COSTA, 2005, pg. 1).

Na descrição e análise deste trabalho podemos verificar o pensamento amparado por um olhar diferenciado do regente frente a seus coralistas. Na visão de Ramos (2003, p.1) "Reger um coro requer muitas habilidades", as quais indica em sua Tese de Livre-Docência apresentada na Escola de Comunicação e Artes da Universidade de São Paulo, intitulada $O$ Ensino da Regência Coral, que habilidades seriam essas as necessárias a um regente, principalmente em um contexto como os dos coros vocacionais ou amadores, onde assume um papel de regente/educador. Segundo Ramos, para o trabalho de Regência Coral é imprescindível:

O exercício da regência pressupõe conhecimento na área de técnica vocal, ouvido apurado para as questões de afinação, timbre, precisão rítmica, desenvoltura com questões analíticas e musicológicas, domínio do repertório e das questões interpretativas de natureza estilística, muita cultura geral, literária e artística. Além disto, na maioria dos casos, é necessário ter uma apurada técnica de resolução de problemas, seja através de atividades educativas, seja sendo capaz de muita clareza para a identificação e criação estratégias para a obtenção de resultados. (RAMOS, 2003, pg.1) 
Desta maneira, neste universo de questões que o regente deve dominar para efetuar seu trabalho, vou me ater às questões das atividades educativas e da resolução dos problemas no campo da escuta melódica, mas sempre me orientando por tais pontos mostrados por Silva Ramos. O foco desta pesquisa é abordar questões relativas ao desenvolvimento da escuta melódica do coralista adulto integrado a coros vocacionais ou amadores, sugerindo procedimentos pedagógicos elaborados a partir de nossas observações de suas necessidades de aprendizagem, com o objetivo de melhorar a performance individual e coral, tornando-o melhor coralista e melhor público. Em relação ao olhar do regente/educador frente a coros vocacionais, Costa explica que:

\begin{abstract}
Sabemos que a qualidade musical passa sempre e necessariamente pela Educação Musical de seus coralistas [...] a reflexão sobre a importância da Educação Musical nesta dupla perspectiva: de "Educação para o Coro", visando a transformação qualitativa do Canto Coral; e de "Educação pelo Coro", entendendo o coro como espaço de oportunidade para o desenvolvimento das capacidades de seus integrantes (COSTA, 2005, anexo 3)
\end{abstract}

Amparados por este pensamento posicionamos nossa atuação como pesquisador e regente de coro, no contexto de desenvolvimento musical do Coral Oficina Comunicantus, tendo como uma das diretrizes de trabalho a seguinte questão: detectar a origem ou origens, os “por quês” das necessidades de aprendizagem e projetar maneiras para ajudar seus coralistas a solucioná-las, de forma interagente e reflexiva.

Dentre os aspectos que deverei também agregar a nossa conduta de atuação, outro que consideramos importante para o desenvolvimento deste trabalho é a maneira pela qual poderemos interferir para que os coralistas possam aprender. Segundo o educador construtivista Javier Onrubia:

[...] a ajuda ajustada pressupõe desafios abordáveis para os alunos; abordáveis não tanto no sentido em que possam resolvê-los ou solucioná-los sozinhos, mas de que possam enfrentá-los graças a combinação de suas próprias possibilidades e os apoios e instrumentos recebidos do professor (ONRUBIA, 2004, pg. 125 e 126).

Embasando-me nas idéias da construção do conhecimento, ou seja, que o conhecimento e os conceitos de ensino/aprendizagem são construídos a partir dos 
conhecimentos prévios que as pessoas têm sobre o conteúdo abordado, desta forma, o regente deve ter a habilidade de analisar as necessidades de aprendizagem e características apresentadas pelas pessoas, em seguida escolher o melhor conteúdo a ser abordado, adequar ao tipo de coralista com que você está trabalhando, que no caso específico dessa pesquisa são adultos integrados a coros vocacionais ou amadores, e desenvolver ferramentas para relacionar o conteúdo que será trabalhado ao que já sabem sobre ele, para assim construir com o grupo o novo aspecto a ser aprendido. Através deste olhar, que é o do regente/educador, não poderei ser uma figura passiva frente ao grupo, mas sim deverei ser atuante e interagente com os dirigidos, agindo de maneira a ajudar o grupo a construir a solução de suas necessidades de aprendizagem e não apenas resolvê-las para eles, para que desta forma o conteúdo seja completamente absorvido.

A habilidade de identificar as necessidades de aprendizagem dos coralistas, associada à capacidade de resolvê-las, são qualidades que um regente precisa incorporar ao seu cotidiano, e que terá amplo valor no âmbito da aprendizagem musical, nos contextos coletivos e sociais e ainda no próprio ambiente do Canto Coral, e este foi o posicionamento que adotamos para a concepção deste trabalho. Uma vez que estamos com o papel de regente/educador estabelecido dentro do ambiente desse trabalho, passemos agora para as principais questões e dificuldades apresentadas pelos coralistas do Coral Oficina Comunicantus, com os quais trabalhamos durante três semestres para a realização desta pesquisa. 


\section{Necessidades de aprendizagem demonstradas pelo Coro e conseqüentes Conteúdos a serem trabalhados}

Um coro que está enquadrado dentro do perfil que citamos no item 1.1 Perfil das pessoas que procuram coros vocacionais, tende a apresentar diversas necessidades que devem ser sanadas a sua evolução musical. A construção da escuta melódica é uma delas, e seu desenvolvimento é fator de extrema importância para a obtenção de um melhor resultado na performance musical. Esta questão vem sendo objeto de diversas discussões dentro das aulas em que discutimos sobre as avaliações e os planejamentos dos ensaios realizados com os coros do Comunicantus: Laboratório Coral e, o desejo de observar melhor este assunto foi crescendo ao longo de minha formação como regente dentro do meu curso de graduação.

Quando surgiu a idéia de criação de um novo coral dentro do Comunicantus sentimos havia surgido o momento adequado para a realização de tal empreitada. Com esta oportunidade em mãos, e em função de nosso trabalho de conclusão de curso da Graduação ter versado sobre o próprio Comunicantus: Laboratório Coral decidimos então apresentar um projeto para ingresso no Programa de Mestrado em Música da ECA-USP, tendo para tanto, sido fortemente inspirado pela dissertação de mestrado de Paulo Rubens Morais Costa, que trabalhou com a diagnose dos problemas em canto coral dentro do Laboratório Coral, com sugestões de atividades agregadas que visavam trazer soluções centradas principalmente nos aspectos rítmicos.

Foi a partir destas influências que surgiu nossa intenção de desenvolver estudos que nos permitissem tratar das necessidades de aprendizagem que o Coral Oficina viesse a apresentar em seu processo de formação, com base tanto na discussão dos relatórios de ensaio (procedimento padrão em todos os ensaios de todos os grupos do Comunicantus: Laboratório Coral, sempre como parte de um método documentador do trabalho) e nossas próprias observações (alinhado a mesma idéia), focalizando neste caso a construção da habilidade da escuta melódica deste grupo de coralistas. 
A partir da definição do perfil $^{3}$ de coralistas que comporiam o Coral Oficina Comunicantus, nos predispusemos em um primeiro momento a observar e anotar quais seriam as necessidades de aprendizagem mais aparentes, e a partir destas observações começarmos a desenvolver atividades para ajudar a supri-las. Para tanto se fez necessária a adoção de um referencial como ferramenta para pontuar quais os conteúdos musicais deveriam ser abordados e em que níveis precisariam ser trabalhados. Acreditamos que sua escolha não poderia ser feita de modo aleatório e sim deveria ser norteada por outros trabalhos que tivessem utilizado mecanismos de avaliação de dados sobre as necessidades de aprendizagem dos coralistas, e com sua eficácia já comprovada, desta maneira então adotamos o referencial do Prof. Dr. Marco Antonio da Silva Ramos, organizado em sua dissertação de Mestrado e amplamente utilizado nos trabalhos do Coral do Museu Lasar Segall e ainda nos outros grupos corais do Comunicantus: Laboratório Coral, juntamente com os trabalhos dos Professores Paulo Rubens Morais Costa e Susana Cecília Igayara, que desenvolveram e continuam desenvolvendo ampla pesquisa dentro da área do Canto Coral.

\subsection{Referencial de Análise de Ramos e Costa.}

Devido ao fato do objeto principal de nosso trabalho ser o desenvolvimento da escuta melódica do coralista integrado a coros vocacionais, decidimos então, falar mais detalhadamente sobre o parâmetro musical "Melodia” e as questões e características que o cercam, para assim delimitar melhor o nosso pensamento sobre o assunto e a direção a ser seguida. Optamos por utilizar a referência de Arnold Schöenberg, que em seu livro "Fundamentos da Composição Musical” aborda conteúdos que devem formar a estrutura e construção de melodias, e divide tal ponto em duas categorias: Melodia Vocal e Melodia Instrumental. Por motivos relacionados à linha de desenvolvimento deste trabalho vamos utilizar apenas a primeira delas, vejamos:

\footnotetext{
${ }^{3}$ Tratado no item 1.1.
} 
É difícil que uma melodia possa apresentar elementos não-melódicos, pois o que é melodioso está intimamente relacionado àquilo que pode ser cantado. A natureza e o caráter do instrumento musical mais antigo - a voz - determina aquilo que pode ser entoado. O cantabile ${ }^{4}$ da música instrumental se desenvolveu como uma adaptação livre do modelo vocal. A melodiosidade, em um sentido mais corrente, implica a utilização de notas relativamente longas, a suave concatenação dos registros, o movimento ondulatório que progride mais por graus que por saltos; implica, igualmente, evitar intervalos aumentados e diminutos, aderir à tonalidade e às suas regiões mais vizinhas, empregar os intervalos naturais de uma tonalidade, proceder a modulação gradualmente e, enfim, tomar cuidado na utilização da dissonância.Outras restrições adicionais derivam dos limites da tessitura vocal e das dificuldades de entoação... (SCHÖENBERG, 2008, p 125 e 126)

Schöenberg nos mostra muito mais do que a estrutura que uma melodia pode ter, ele evidencia diversos pontos passíveis de serem trabalhados na direção do desenvolvimento da escuta melódica do coralista pertencente ao perfil do qual estamos tratando.

O trabalho de Shöenberg fundamentou conceitos musicais com um pensamento fortemente estruturador inspirando diversos trabalhos musicais, dentre eles, a dissertação de Mestrado intitulada Referencial de Análise de Obras Corais (1989) elaborada pelo Prof. Dr. Marco Antonio da Silva Ramos, reformulado no Referencial de Análise de Obras Corais da Tese de Livre Docência em 2003 e atualizado recentemente ${ }^{5}$, onde aborda diversos elementos de caráter estrutural das obras corais, que foi desenvolvida com o objetivo de servir como ferramenta de apoio ao trabalho do regente para o estudo e a preparação de repertório direcionado ao melhor desenvolvimento do seu coro. Sua organização parte das relações que os conteúdos musicais têm com o parâmetro musical "som”, dividindo-os nos seguintes itens: “Aspectos relativos às durações”, “Aspectos freqüenciais”, “Aspectos relativos às intensidades”, “Aspectos relativos ao timbre”, “Aspectos relativos ao silêncio”, “Aspectos estruturais, formais e composicionais” e “Aspectos técnicos (para performance)”.

Este trabalho de Ramos, seguindo o mesmo caminho, também inspirou e fundamentou diversos outros, dentre os quais cito Canto Coral: parâmetros para análise e ferramentas para a avaliação, de 2005, dissertação de Mestrado de Paulo Rubens Morais Costa, que trabalhou muitos anos ao lado de Silva Ramos e também da Professora Mestre Susana Cecília Igayara, atuando intensamente junto aos coros do Comunicantus: Laboratório Coral. Em sua experiência durante este período escreveu um trabalho onde documentou diversas experiências de desenvolvimento dos coralistas, e assim criando ferramentas a partir

\footnotetext{
${ }^{4}$ Destaque em itálico do autor.

${ }^{5}$ Tive acesso pessoalmente a novas atualizações feitas pelo autor.
} 
destes conhecimentos buscando a melhoria da qualidade musical e da performance do grupo. Costa (2005, p. 87) define o objetivo de seu trabalho assim: “... o objetivo da presente dissertação é propor ferramentas de diagnose que auxiliem o regente a olhar para o interior do seu coro e enxergar com a maior nitidez possível o seu perfil, as suas características”. Por esta definição, do próprio autor, notamos o intento de diagnosticar previamente as necessidades de aprendizagem a serem atendidas para, a partir da constatação das mesmas, orientar-se para a escolha do conteúdo ou da metodologia mais adequada à solução da questão.

Observamos então que estes trabalhos foram concebidos com o intuito de constituir ferramentas que possam ser utilizadas como referenciais para ajudar o regente na busca por melhores resultados em sua atuação frente o coro, possibilitando a escolha de soluções para as necessidades de aprendizagem de seu grupo. Ramos e Costa empregam os aspectos musicais a partir de um critério de organização desenvolvido durante ampla pesquisa com coros vocacionais, de modo que o regente tenha sua disposição um poderoso material de auxílio para uma observação mais detalhada sobre diversos aspectos musicais.

Durante meu tempo como aluno integrado ao Comunicantus: Laboratório Coral conheci o teor do trabalho de Ramos além de tê-lo experimentado na prática, também tive a oportunidade de presenciar o desenvolvimento do trabalho de Costa, participando ativamente de diversas atividades trabalhadas com os coros vinculados ao Comunicantus, principalmente o Coral Escola, onde eu era, na época aluno (graduando) regente, e pude verificar o desenvolvimento consistente dos grupos a partir da utilização destes referenciais de apoio pedagógico, de forma que estas foram influências fundamentais em minha formação como regente e educador musical, que geraram e ainda geram reflexões fecundas sobre a maneira como devo atuar em meus coros.

Aquela experiência estimulou-me a desenvolver posteriormente meu Trabalho de Conclusão de Curso orientado pela Prof. a Susana Cecília Igayara, intitulado "Canto Coral: Um caminho para a Educação Musical na experiência do Projeto Comunicantus” (2006), onde utilizei os conceitos incorporados ao longo de minha formação, dentro das aulas e ensaios que fazem parte da disciplina Práticas Multidisciplinares em Canto Coral com estágio supervisionado, já amparado por conhecimentos obtidos através da dissertação de Ramos, embora de uma forma mais prática e menos sistematizada, mas com os conceitos bem definidos, conforme está registrado em meu primeiro trabalho.

Durante este processo de finalização de curso de graduação e de elaboração do meu trabalho, o anseio de continuar pesquisando sobre processos de aprimoramento de técnicas de 
abordagem de ensaio, o que me levou a estender a reflexão sobre os trabalhos de Ramos e Costa em nível de pós-graduação, para assim utilizar tais ferramentas no âmbito do desenvolvimento da escuta melódica do coralista vinculado a coros vocacionais, com o intuito de contribuir trazendo um conjunto de questões que dizem respeito à aplicabilidade de seus referenciais no assunto escolhido, principalmente nas questões que implicam a entoação das alturas e da afinação cada vez mais precisa e/ou exata.

Optamos por utilizar o trabalho de Ramos como base referencial de análise para definição de uma série de conteúdos a serem desenvolvidos com o grupo Oficina Coral Comunicantus, apoiado pelo trabalho de Costa como metodologia na diagnose das dificuldades de aprendizagem apresentadas, de forma que vamos combinar aspectos das duas obras para identificar as questões musicais e sugerir possíveis soluções para o grupo. Uma vez que nos dispusemos a lidar com tal material, pareceu importante trazer para a discussão diagnóstica e de proposição de exercícios práticos, certos pontos que são apresentados no item referente exatamente aos Aspectos Freqüênciais (no modelo que tive acesso em 2008 atualizado pelo autor). Para nos auxiliar, dentro do trabalho de Costa utilizarei além de outros pontos o Roteiro para a Observação de Ensaio e de Performance, e para complementar as ferramentas desta investigação, vou utilizar os trabalhos da Professora Susana Cecília Igayara na área de repertório coral, pois a pesquisadora desenvolve um trabalho de adequação do repertório ao nível de desenvolvimento do coralista, de forma que seja possível o coro realizálo eficientemente, mas, que sempre traga desafios para serem superados, de forma que o grupo seja impelido a um desenvolvimento progressivo à medida que as músicas são aprendidas.

As necessidades de aprendizagem que o Coral Oficina apresentou durante o seu processo de formação e desenvolvimento iniciais assinalaram (logicamente por esta condição), diversos aspectos e conteúdos musicais que precisaram ser trabalhados, sendo muitos deles ligados a questões do desenvolvimento da escuta melódica. Na leitura do trabalho de Costa, em sua dissertação de Mestrado, que como já dissemos anteriormente, é parte dos trabalhos desenvolvidos dentro do Comunicantus: Laboratório Coral, encontramos exemplos de aplicabilidade de seu sistema no parâmetro do tempo, mais especificamente nas questões rítmicas. Pelo fato de ter acompanhado de perto tal trabalho, sentimos necessidade de nos aprofundar em busca de ações no campo da escuta melódica em grupos deste perfil, desenvolvendo um conjunto de atividades pedagógicas que possibilitassem a promoção de tal 
escuta de modo mais apurado em cada coralista, com a intenção de afetar positivamente os resultados obtidos na abordagem das questões relativas ao parâmetro musical: Freqüencia ${ }^{6}$.

Então, a partir dos trabalhos de Costa, Igayara e Ramos, constituímos um conjunto de quesitos, formando um novo referencial, para orientar nossos estudos e nossa reflexão, voltado para pontos inerentes à escuta melódica, para ser utilizado junto ao Coral Oficina Comunicantus. Este nosso novo referencial também foi usado para a criação de atividades práticas, conforme o pensamento acima descrito, ajudando na abordagem das necessidades de aprendizagem dos coralistas, alinhando-me ao pensamento de ensino pedagógico musical realizado com os grupos integrados ao Comunicantus: Laboratório Coral.

Assim sendo, dentre os vários conteúdos abordados, selecionamos os seguintes aspectos freqüenciais, constitutivos de nosso referencial de observação, que será utilizado na realização deste trabalho:

\section{REFERENCIAL DE OBSERVAÇÃO DE ASPECTOS FREQUENCIAIS}

- Afinação ${ }^{7}$ das alturas $^{8}$;

- Cantar intervalos melódicos ascendentes e descendentes;

- Percepção e capacidade de emissão dos cromatismos;

- Memorização melódica;

- Correção e qualidade na realização dos fraseados da música;

- Manutenção da afinação ao longo da peça;

- Fraseado;

- Qualidade de afinação dentro dos naipes - afinação das melodias;

- Qualidade de afinação entre os naipes - afinação das simultaneidades;

\footnotetext{
${ }^{6}$ Freqüência: O número de vibrações por segundo de um som (SADIE, 1994, p. 344)

${ }^{7}$ Observada como a habilidade de cantar as alturas com precisão.

${ }^{8}$ A altura é determinada por aquilo que o ouvido capta como sendo a freqüência da onda mais fundamental de um som (SADIE, 1994, p. 25).
} 
- Consciência física da emissão sonora (memória da tessitura);

- Postura corporal geral do coro;

- Consciência auditiva do próprio som;

- Consciência de sua nota na harmonia;

- Consciência e compreensão melódica;

- Percepção das outras vozes

- Promover a prática do canto coral a 2,3 e 4 vozes e a habilidade para tanto.

Obs.: Durante o trabalho de observação surgiram outros aspectos indiretamente relacionados à escuta melódica, utilizados para abordagens em determinados contextos. Embora alguns desses tenham sido relacionados junto com aos pontos citados em determinados ensaios, não os consideramos como parâmetros a serem incluídos em nosso referencial.

Vamos utilizar estes pontos selecionados dentro dos trabalhos de Ramos e Costa como referencial utilizando-os como parâmetro para fazer a diagnose das necessidades de aprendizagem no campo da escuta melódica que interferem na qualidade da performance do coral citado, documentando os procedimentos pedagógicos utilizados durante o período de formação deste grupo em que o trabalho realizado, e a partir do material obtido durante as observações dos ensaios, desenvolver atividades para a solução destas questões melódicas junto a seus coralistas. Como é rotina dentro do trabalho no Comunicantus: Laboratório Coral, todos os ensaios estão registrados através de planejamentos e avaliações feitos pelos monitores do projeto, assim, pedi autorização ${ }^{9}$ a eles e ao coordenador para utilizar o conteúdo destes documentos como fonte de consulta dos processos de ensino/aprendizagem que foram discutidos e avaliados sistematicamente, com intuito de analisar os procedimentos realizados e refletir sobre os caminhos que foram seguidos pelo coro a partir dos resultados obtidos.

Conforme iremos tratar ao longo deste trabalho, os pontos onde foram evidenciadas as principais necessidades de aprendizagem do grupo coral citado, em relação ao desenvolvimento de sua escuta melódica foram:

\footnotetext{
${ }^{9}$ As autorizações encontram-se depositadas no Comunicantus: Laboratório Coral do CMU-ECA/USP.
} 
- Os aspectos freqüenciais como: afinação das alturas, ressonância, variações de intensidade, timbre;

- Os aspectos sensoriais: percepção auditiva, memória musical, consciência de frase musical, consciência dos eventos sonoros;

- Os aspectos físicos (corporais): respiração, articulação para o canto, consciência física, apoio e consciência vocal;

- Os aspectos técnicos como: textura, ritmo, polifonia, harmonia e a estruturação das vozes.

Embora utilizemos parâmetros freqüênciais para a realização deste trabalho, não podemos deixar de considerar outros aspectos como, por exemplo: o sensorial e o físico, pois poderia nos levar a cometer equívocos na análise dos dados. Em música os parâmetros estão interligados e sua realização depende destas interligações, por esse motivo vamos tratar desses pontos em momentos em que estiverem vinculados. Vários conhecimentos e habilidades estão atrelados compondo o que é chamado na área de Educação de Conteúdo de Aprendizagem, e é indispensável observar a coexistência destes fatores para ter fundamentos para poder levar o coro ao entendimento e a execução de um ou mais parâmetros musicais. Segundo Zabala $(1988$,

(...) tudo quanto se tem que aprender para alcançar determinados objetivos que não apenas abrangem capacidades cognitivas, como também incluem as demais capacidades. (...) Portanto, também serão conteúdos de aprendizagem todos aqueles que possibilitem o desenvolvimento das capacidades motoras, afetivas, de relação interpessoal e de inserção social.

Zabala em sua citação é tão preciso que até parece que ele estava se referindo a área de Canto Coral, pois descreve exatamente alguns dos principais conteúdos a serem desenvolvidos com coralistas. Podemos concluir a partir da consideração deste conceito que a abordagem de outros parâmetros que não apenas os relativos à freqüência podem levar a 
construção do mesmo pelos integrantes do coro, pois os diversos aspectos musicais são naturalmente complementares, e sua abordagem seccionada pode não alcançar o resultado pretendido, enquanto que o atrelamento dos aspectos musicais e seu emprego conjunto poderão facilitar e acelerar o processo de ensino/aprendizagem por utilizarmos suas relações de complementaridade.

No caminho da verificação das necessidades de aprendizagem apresentadas pelos coralistas, vamos utilizar os procedimentos e as escolhas presentes em alguns planejamentos e avaliações escritos durante o período de realização dos ensaios observados, isto para obter maior clareza no ponto de vista da análise dos processos didáticos utilizados ao longo do período de realização deste trabalho, que se amparou na utilização dos conceitos de ensino/aprendizagem. Norteados por este princípio, o termo “procedimentos”, como aqui utilizaremos, está tomado na acepção descrita no trabalho intitulado Diagnose em Canto Coral: parâmetros para análise e ferramentas para a avaliação, de Moraes Costa, que durante sua experiência junto a diversos corais (principalmente o Coro do Museu Lasar Segall e o Coral Escola Comunicantus) definiu tal termo da seguinte maneira:

Os procedimentos são formas determinadas e concretas de agir, não arbitrárias, ordenadas de maneira sistemática, orientadas para a consecução de uma meta. Os procedimentos são sempre os resultados de uma ação ou de um conjunto de ações. (COSTA, 2002, anexo 15).

Esta definição de Moraes Costa reflete em grande parte a metodologia utilizada para o desenvolvimento dos corais dirigidos pelo Comunicantus: Laboratório Coral, e nos apontou o caminho a ser trilhado nesta investigação, as escolhas dos conteúdos musicais assim como a definição das estratégias didáticas para a realização dos ensaios, e sempre observando os resultados destas ações para indicar a melhor opção de ensino/aprendizagem necessária para a seqüência do trabalho. 


\subsection{A Escuta Melódica e a Afinação Coral}

Este item trata de duas questões muito importantes para o trabalho coral. A primeira delas é pouco observada pelos músicos. A escuta da melodia. Para eles este aspecto é considerado o mais simples e até mesmo o mais evidente dentro do contexto de uma música, que possui diversos outros elementos sonoros como os acordes, as cadências, o ritmo, etc., que são mais complexos de serem identificados por uma pessoa que não tenha o ouvido treinado. Mas, para o perfil de coralista que estamos tratamos, cabe a nós fazer uma pergunta: Como eles ouvem a música? Esta pergunta dentro de nossa investigação é muito importante, pois dentro deste trabalho considerar o que o coralista amador traz de informação é indispensável para podermos abordar a questão do desenvolvimento da escuta melódica, sobretudo pelo fato do Coral Oficina Comunicantus estar em sua fase de formação, sendo essencial saber quais são as bases musicais que os seus integrantes possuem.

O músico, pesquisador e educador musical Murray Schafer (1986, p. 67) diz o seguinte sobre a importância de um trabalho que está em seu início:

Senti que minha primeira tarefa neste curso seria a de abrir os ouvidos: procurei sempre levar os alunos a notar sons que na verdade nunca haviam percebido, ouvir avidamente os sons do seu ambiente e ainda os que eles próprios injetavam nesse mesmo ambiente.

As pessoas estão expostas a todas as espécies de sons durante sua vida, e muitas vezes não percebem que eles estão acontecendo, ou seja, que os estão ouvindo. Por exemplo, enquanto estou escrevendo em meu computador ouço diversos sons como o de suas teclas, o toque telefone, o portão bater, carros passando, o vento nas árvores, vozes de pessoas conversando e uma série de outros sons que geralmente passam despercebidos pelas pessoas. Acredito ser preciso chamar a atenção das pessoas para estes sons, para nomear esta tarefa Schafer usa a expressão "abrir os ouvidos”, mas para este trabalho consideramos ser mais adequada a definição de Silva Ramos que afirma que aos coralistas “é necessário ligar os ouvidos” (Informação Verbal) ${ }^{10}$. As pessoas em seu dia a dia convivem com todo o tipo de

\footnotetext{
${ }^{10}$ RAMOS, Marco A. da S. Comentário de aula na disciplina Práticas multidisciplinares em canto coral com estágio supervisionado da USP, São Paulo, set, 2004.
} 
sons, mas sua própria rotina diária e a sua preocupação com os problemas do cotidiano desviam sua atenção para outros eventos deixando seus ouvidos “desligados” aumentando assim sua concentração em suas atividades e diminuindo a percepção auditiva. No processo para desenvolver a escuta melódica é preciso conseguir que os integrantes do seu coro "liguem” seus ouvidos, de forma que para eles o som saia da esfera do quase imperceptível, porém vagamente compreensível (e, portanto, inexatamente factível), e que eles comecem a notar a quantidade de variantes sonoras a sua volta, em seu ambiente, desta forma chamando sua atenção para um aspecto que passava quase despercebido, a existência do som no cotidiano, ou melhor, as variantes destes sons, convidando-os para atentar para os acontecimentos sonoro-musicais que ocorrem em seus ensaios. Costa (2005, p. 8), em sua dissertação de mestrado afirma que: “Quanto maior é a quantidade e a qualidade de estímulos apresentados pelo ambiente, maiores são as probabilidades de um indivíduo desenvolver suas capacidades”. Mas muitas vezes a simples exposição a estes estímulos não é suficiente para garantir que as pessoas os percebam, muitas vezes é necessário dirigi-los para uma percepção consciente dos sons a sua volta.

Desta maneira, o regente pode orientar seus coralistas para que comecem a notar esta riqueza sonora que os cerca em seu cotidiano, e assim chamar a atenção deles para a escuta consciente que se dá de forma deliberada, conduzindo-os assim a uma escuta mais participativa voltada para o ensaio. Este recurso pode ajudar o regente no processo de desenvolvimento da percepção auditiva de seu coro. Mas sabemos que não basta levá-los a perceber este tipo de sons no dia a dia para ter sucesso na realização musical, porém através deste procedimento, o regente pode começar a mostrar o som como um material possível de ser manipulado, percebido e até modificado por eles, transformando o elemento sonoro em uma experiência vivenciada na prática, como nos afirma Schafer (1986, p. 68) nos relata num de seus trabalhos que: “Como músico prático, considero que uma pessoa só consiga aprender a respeito do som produzindo som; a respeito da música, fazendo música”.

Em nosso trabalho cotidiano pudemos constatar a utilidade da frase de Schafer. A partir da realização de atividades musicais onde os coralistas tiveram contato direto com o fazer musical, o resultado da escuta sonora e de identificação de melodias se tornou muito mais evidente para os integrantes do Coral Oficina Comunicantus. Eles iniciaram o processo para ligar seus ouvidos, começando a notar os sons que os cercam e assim vivenciando o momento em que seu ouvido passa a ser usado conscientemente, e a Música, que para eles era 
um acontecimento tão distante, passou a estar ao seu alcance, pois estavam começando a ter consciência da existência do som como elemento passível de ser manipulado e dominado. Desta maneira, podemos concluir que aproximar as pessoas do objeto sonoro propicia a sua compreensão e execução. Nesta direção Costa (2005, p. 8) afirma que:

(...) a aprendizagem equivale a elaborar representações pessoais sobre os objetos da realidade que se quer aprender. Esta atribuição de significados pessoais a aspectos particulares da realidade é fruto da ação do indivíduo sobre este aspecto, seja esta ação de caráter mais intelectual, motor ou afetivo.

Assim, podemos verificar o quanto é necessário para o desenvolvimento do coralista integrado a coros vocacionais, interagir com o objeto de sua necessidade de aprendizagem, para, a partir deste contato “auditivo consciente” (percepção de sua existência) e vocal (manipulação e controle) do som ele comece a desenvolver suas potencialidades musicais de uma maneira mais efetiva. Segundo Cesar Coll e Isabel Solé (in Coll et al, 2004, p. 20): "Quando ocorre este processo, dizemos que estamos aprendendo significativamente, construindo um significado próprio e pessoal para um objeto de conhecimento que existe objetivamente”.

Utilizando estas diretrizes de Schöenberg com relação à estrutura de uma melodia ${ }^{11}$, podemos criar frases musicais que podem ajudar o coralista a desenvolver sua escuta melódica. Quando começamos a cantar seqüências melódicas simples (a partir de duas notas diferentes já podemos criar melodias para trabalhar com os coralistas) para o coro repetir em seguida, já estamos trabalhando a escuta melódica, pois a repetição de um som sempre depende da escuta correta do mesmo, e a emissão deste mesmo som mostra se a escuta está correta ou não, ou ainda pode apontar para outra questão que impede a entonação correta da atividade proposta, o que levaria a outra forma de abordagem (trataremos destas questões em outro momento). A partir desta observação percebemos que é necessário estabelecer com os integrantes do seu coro vocacional uma referência inicial de afinação, onde, através da qual possamos iniciar o desenvolvimento da escuta melódica do grupo. Desde seu início, o trabalho deve estar voltado para "ligar" os ouvidos dos coralistas, pois este é o aspecto que fará toda a diferença no resultado final de seu trabalho. Vejamos o exemplo a seguir:

\footnotetext{
${ }^{11}$ Página 16.
} 


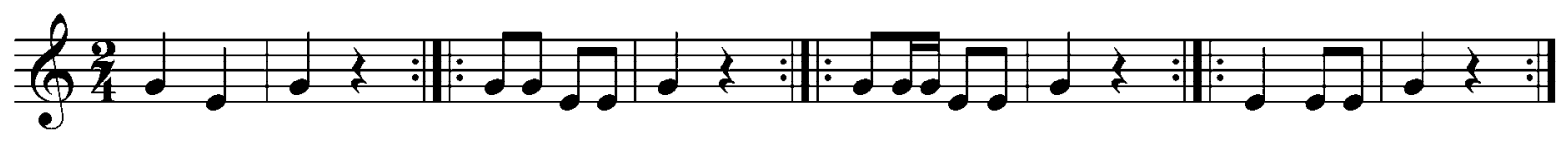

A execução deste exercício é bastante fácil. Consiste em cantar os intervalos melódicos com o nome de suas notas, pedindo ao coro para repetir a mesma frase melódica apresentada, tomando cuidado para cantar sempre um modelo ${ }^{12}$ por vez. Através deste procedimento tão simples, pode ser obtido um resultado inicial muito eficiente a cerca do trabalho de desenvolvimento da escuta melódica, além de facilitar a identificação de necessidades de aprendizagem gerais ou específicas que seus coralistas possam ter. Mas façamos uma pergunta neste momento: Será que a partir desta atividade entorno de um intervalo de terça menor os coralistas já terão começado a "ligar seus ouvidos”? Não podemos afirmar que esta atividade já resolveria completamente a demanda, mas sugerimos um caminho possível para a seqüência da atividade, podemos perguntar aos coralistas se já ouviram estes sons (intervalo melódico proposto) anteriormente em seu cotidiano, buscando aproximar estes sons do meio em que convivem. Se não conseguirem, podem ser dados exemplos de alguma máquina ou mecanismo que reproduza os sons deste intervalo e deixe-os perceber que eles já o conheciam inconscientemente, mas não percebiam sua existência, por exemplo, o som produzido por um elevador quando para em um andar, note que a partir do momento que os integrantes de um coro principiarem a identificação dos elementos sonoros (melódicos) constantes nas músicas e nos vocalises que estão aprendendo, relacionando e constatando que estes sons já estavam presentes em diversos momentos de seu dia a dia, eles podem, a partir daí, iniciar um processo em que os sons não serão mais ouvidos de forma despercebida, pois eles conscientemente poderão direcionar sua audição para ouvir os sons a sua volta de uma maneira inteligente, procurando entende-los e até compará-los entre si (como o som do elevador já citado comparado a alguns tipos de campainha), ou seja, "ligar seus ouvidos”, e conseqüentemente, este fato pode induzir ao desenvolvimento de sua escuta melódica, pois voluntariamente estarão mais atentos e sensíveis aos elementos musicais trabalhados nos ensaios, tornando-se coralistas mais concentrados e eficientes auditivamente.

A segunda questão é a afinação coral. Este parâmetro, do ponto de vista estéticomusical é um dos mais importantes no ambiente do canto coral, pois a afinação coral mostra

\footnotetext{
${ }^{12}$ Neste caso, a proposta apresenta modelos com dois compassos e apenas um intervalo melódico (terça menor), mas nada impede de fazê-lo com modelos mais extensos que utilizem outros intervalos.
} 
muito da condição musical e auditiva do coro. Mas como trabalhar a qualidade da afinação de um coro? A partir de quais bases podemos iniciar o desenvolvimento deste trabalho? Qual seria o referencial de afinação que o regente deve adotar para perseguir durante os ensaios? Qual o referencial de afinação que os coralistas têm? Nós não estamos falando de padrões da Física que envolvem freqüência entre outros parâmetros (embora sejam importantes), mas de aspectos mais diretamente relacionados à percepção auditiva. Será que é possível afinar uma música a duas vozes com um coro sem que os naipes consigam cantar corretamente suas linhas? A afinação coral depende do desenvolvimento da escuta melódica, a partir da audição e entoação correta de linhas melódicas os coralistas poderão perceber se estão cantando corretamente ou não, e assim começar o processo de afinação coral. Costa em seu trabalho, quando aborda este assunto afirma que “(...) além de estar relacionada com o domínio do aparato vocal a afinação também depende diretamente da percepção auditiva do aspecto frequencial (...)” (COSTA, 2005, p. 84). Segundo Duane Crowther (1981 apud COSTA, 2005, p. 83), afinação é o termo que indica o grau de fidelidade da voz em relação a uma freqüência estabelecida. Partindo destas premissas (no que diz respeito ao propósito deste trabalho) podemos considerar que afinação é a capacidade de cantar, ou seja, entoar as alturas com precisão.

Lembrando Schafer, já citado neste trabalho, é preciso produzir, participar das atividades musicais para poder dominar os aspectos sonoros. Desta maneira, a afinação só poderá ser atingida pelos coralistas se for intensamente buscada dentro dos ensaios. Quanto mais o som for trabalhado e manipulado pelos coralistas, maior será seu desenvolvimento na procura pela afinação coral, de modo que se as atividades tiverem como objetivo o desenvolvimento de parâmetros de freqüência como os intervalos utilizados no exercício mostrado no exemplo anterior da figura anterior, relacionando-os com seus conhecimentos de eventos sonoros, poderão nortear seu caminho no estabelecimento de uma referência sonora para servir de base para o trabalho com os aspectos musicais.

Sobreira em seu livro "Desafinação Vocal”, fala sobre os diversos fatores que envolvem a afinação, relatando sobre suas modalidades, origens e contextos. A partir deste olhar, ela define afinação da seguinte forma:

Para compreender, portanto, o significado de uma boa afinação, deve-se verificar o contexto no qual esta é avaliada. Afinar é estar de acordo com um determinado sistema, seja ele qual for. A capacidade de afinação de uma pessoa, seja vocal ou instrumentalmente, é diretamente proporcional à sua integração ao sistema em questão e a sua habilidade em reproduzir sonoramente as relações intervalares 
propostas em tal sistema; uma pessoa afinada é capaz de se adaptar, com facilidade, às inflexões exigidas pelas diversas situações musicais sendo capaz de afinar sozinha ou em grupo. (2003, p. 29)

Sendo assim, preparar o coralista dentro do universo do canto coral, de forma que ele consiga se familiarizar e dominar todos os aspectos relativos a este contexto sonoro em que está inserido pode ajudá-lo a alcançar a afinação coral.

Retomando então a pergunta que aborda a possibilidade de executar uma peça musical a duas vozes, sabemos que para os coralistas se trata de uma situação a qual não estão familiarizados, pois para eles é como se estivessem cantando duas canções distintas simultaneamente, prática a qual geralmente não existe em seus cotidianos, mas que é característica do fazer coral, além de que muitos deles nunca haviam percebido ou soubessem que isto fosse possível de ser realizado. Uma das possíveis explicações para este fato é que de um modo geral, as pessoas quando cantam em grupo como em igrejas, escolas ou em outros contextos sempre o fazem entoando a mesma melodia, a que é ensinada com o texto, mesmo quando ocorre acompanhamento instrumental onde se têm acordes compondo a harmonia da música durante a execução, a sua atenção fica profundamente voltada para a melodia do texto, fator que pode levá-los a não perceber a coexistência de outras melodias paralelas à principal, criando uma dificuldade maior quando necessitam aprender uma voz diferente e que deve ser cantada simultaneamente com a melodia já conhecida.

É bastante comum quando dividimos o coro em dois naipes, que um seja influenciado pela melodia do outro, causando instabilidade e desafinação, pois há uma tendência sócio-cultural de cantar sempre a linha que é considerada a da melodia. À medida que os coralistas vão desenvolvendo sua escuta melódica, eles adquirem segurança para cantar a linha musical que lhes foi delegada e acabam não sofrendo a influência da outra, ou mesmo de outras linhas simultâneas. Para ajudar os coralistas a desenvolverem tal habilidade (cantar uma melodia ouvindo outra simultaneamente) podemos usar a seguinte atividade:

Ensinar ao coro um quodlibet ${ }^{13}$ (iniciando com uma obra que possua apenas duas melodias), até que consigam cantar as linhas corretamente. Em seguida, peça para o grupo cantar as duas melodias, uma em seguida da outra, como se uma linha fosse a continuação da outra. Quando o coro estiver cantando de maneira desenvolta, separe o coro em dois grupos, A e B, em seguida peça para o grupo A cantar a primeira melodia para o B apenas ouvir, logo

${ }^{13}$ Composição, geralmente de tipo ligeiro ou bem humorado, em que trechos de melodias e textos conhecidos aparecem em combinações sucessivas ou simultâneas (SADIE, 1994, P. 759). 
após peça ao grupo B para cantar a segunda melodia enquanto o A fica ouvindo, dando a impressão inicial de que fosse uma música em que cada grupo canta um trecho diferente. Depois, troque as melodias entre os grupos e repita o procedimento, isto ocorrendo várias vezes até ficar orgânico e sem interrupções entre as melodias. Logo após, peça para o grupo A cantar a primeira melodia e quando chegar o momento de cantar a segunda melodia diga ao grupo B para começar a cantar(conjuntamente) a primeira melodia, de maneira que cada grupo cantará uma melodia diferente simultaneamente a outra, e quando o terminarem suas respectivas melodias iniciar seguidamente a outra de forma que seja um processo contínuo até a se sentirem à vontade com a atividade.

Esta modalidade de composição musical prepara o coro para a realização musical simultânea de músicas a duas vozes diferentes que se encaixam harmonicamente. Desta forma, o regente trabalha a escuta melódica do coro na condição de que cada grupo consiga cantar a sua melodia sem ser influenciado pela cantada pelo outro, pois ambos os grupos já conhecem as duas e este fato lhes dá segurança para executarem suas respectivas linhas melódicas sem serem influenciados ou desestabilizados.

Sugerimos assim que trabalhando o desenvolvimento da escuta melódica desta forma, poderemos começar a obter resultados no campo da afinação coral, pois usando o artifício de cantar melodias distintas concomitantemente exercita-se a habilidade de cantar e ouvir freqüências diferentes e simultâneas, podendo assim dar início à preparação do coro para executar repertório a duas ou mais vozes, e futuramente, até obras com maior complexidade, como as de caráter homofônico (a três e quatro vozes) e polifônico, o que exige uma escuta melódica ainda mais desenvolvida.

Dentre as necessidades de aprendizagem apresentadas pelos coralistas do Coral Oficina Comunicantus, decidimos então abordar estes dois pontos: a escuta melódica e a afinação do coral, considerando os aspectos a eles pertinentes a este momento que é o início de um trabalho de formação de um coro vocacional. As inter-relações que existem entre estes dois pontos são vasta fonte de material a ser tratado dentro do contexto do Canto Coral, por isso vamos nos deter a discutir as necessidades de aprendizagem demonstradas pelos coralistas no trabalho de formação desenvolvido com o Coral Oficina Comunicantus, assim como os recursos adotados para solucioná-las dentre outras alternativas passíveis de serem utilizadas. 
2.3. Escolha do repertório e tipologia dos conteúdos de ensino/aprendizagem trabalhados com os coralistas

Depois das questões tratadas no ponto anterior, a escolha do repertório que o regente irá trabalhar adquire uma importância muito grande no que se refere ao desenvolvimento musical e principalmente a escuta melódica dos coralistas. Os conteúdos musicais de cada peça irão determinar a condução do trabalho, pois os tipos e níveis de necessidades de aprendizagem (no caso desta pesquisa estamos trabalhando com os aspectos melódicos) demonstrados podem influenciar a escolha dos procedimentos didáticos que serão utilizados no processo de ensino/aprendizagem do grupo, e por sua vez, esta decisão implica na qualidade do desenvolvimento atingido pelo grupo. Igayara aborda esta questão em diversos momentos de seu trabalho, neste texto que faz parte do Relatório Técnico enviado em 2002 à Fundação Vitae, ex-patrocinadora do Comunicantus: Laboratório Coral, ela afirma:

(...) a escolha do repertório é um fator de crescimento de um grupo coral, ou então de estagnação e até de retrocesso, na medida em que as obras escolhidas podem ser capazes de canalizar as potencialidades musicais dos coralistas e do regente em direção a um resultado musical de bom nível ou, estando muito além ou aquém da capacidade e do interesse musical do grupo, a obra pode representar um desafio inatingível ou um resultado sem nenhum interesse. (IGAYARA, 2002, sem p.)

Vemos então que escolher o repertório antecipando as possíveis necessidades de aprendizagem que poderão surgir durante o processo de ensino das músicas para o coro pode determinar o resultado final do trabalho. Embora saibamos que sempre possam surgir necessidades que não estavam no planejamento, o que é perfeitamente admissível em qualquer área de atuação, planejar os ensaios preparando atividades pertinentes ao repertório que será trabalhado está diretamente relacionado ao nível de sucesso que se pode obter. A partir de uma análise previa dos conteúdos de aprendizagem selecionados e da avaliação das potencialidades dos integrantes do coro, o planejamento pode ser elaborado como um guia para orientação do regente enquanto trabalha com os coralistas. Este recurso pedagógico pode ajudá-lo a perceber mais claramente as necessidades apresentadas e o contexto em que deverão ser solucionadas, pois lhe confere segurança e organização para escolher os procedimentos adequados para serem empregados futuramente, além de ajudar a elaboração de um esboço de plano de trabalho. 
Neste sentido a escolha do repertório que é desenvolvido com os corais integrados do Comunicantus: Laboratório Coral é realizado da seguinte forma:

(...) a orientação dada aos alunos pressupõe que eles pesquisem e sejam responsáveis pelo repertório escolhido para ser ensaiado pelos coros e apresentado ao público, numa opção de orientação não impositiva. As obras que formam o repertório dos coros comunitários são sugeridas pelos próprios alunos em formação e, somente em último caso pelos professores. Depois do processo de seleção, a obra passa por uma leitura em classe (leitura aqui entendida como realização musical cantada a partir da partitura), pelo levantamento das questões técnicas que cada obra apresenta, pela análise das dificuldades, desafios e interesses pedagógicos e artísticos propostos pela obra e sua adequação às necessidades, capacidades de realização e interesse musical dos coralistas, dos alunos envolvidos no aprendizado (como regentes, pianistas, cantores) e do publico ouvinte a quem serão apresentadas as obras. (IGAYARA, 2006, p. 186 e187)

Podemos observar que são diversas as questões que influenciam a escolha de um repertório para um coro. Dentre elas vamos destacar as seguintes: dificuldades, desafios, adequação, necessidades, capacidades e interesse. Estas expressões são norteadoras deste trabalho, pois ele consiste em utilizar o repertório escolhido mediante a observação de tais aspectos, considerando o estágio de desenvolvimento musical em que os coralistas estiverem na ocasião, quais suas necessidades de aprendizagem, suas capacidades momentâneas, seus interesses musicais, quais as dificuldades oferecidas pelo repertório e os desafios oferecidos por ele possíveis de serem superados naquele momento, desta maneira observamos que a escolha é realizada através de uma dinâmica onde possam crescer musicalmente, havendo sempre desafios que façam que os coros continuem ampliando suas habilidades musicais e vocais. Diante desse contexto verificamos que nosso trabalho frente a tal perfil de coralista indica que o regente:

1. Em primeiro lugar, deve levar em conta (...) os esquemas de conhecimentos dos alunos relacionados ao conteúdo de aprendizagem tratado e tomar como ponto de partida os significados e os sentidos que os alunos disponham em relação a este conteúdo.

2. Mas, ao mesmo tempo, deve provocar desafios que o leve a questionar estes significados e sentidos e forcem sua modificação pelo aluno, e assegurar que essa modificação ocorra na direção desejada, isto é, aproximando a compreensão e a atuação do aluno das intenções educativas. (ONRUBIA, 2004, p. 125) 
De maneira que:

(...) o coralista possa ter suas potencialidades desenvolvidas, seus conhecimentos musicais e dos assuntos relacionados ao canto ampliados progressivamente, e uma familiaridade cada vez maior com a linguagem musical. Estes pressupostos permeiam todas as atividades, do vocalize ao ensaio conjunto, passando pelos ensaios de naipe, pelos cursos, palestras e discussões cotidianas. (RAMOS, 1988, p. 38)

Para o trabalho com o Coral Oficina Comunicantus, que se tratava de um grupo do qual não conhecíamos seus integrantes, mas sim o seu perfil ${ }^{14}$, a escolha da peça inicial foi orientada por todos esses aspectos, devido ao fato de ainda não termos dados sobre o tipo de formação musical que nossos futuros coralistas poderiam ter, ou mesmo alguma experiência com aprendizado musical, como aulas de instrumento, canto, etc. Nas nossas discussões em sala de aula sobre qual deveria ser a peça para começarmos o trabalho, buscamos no amplo arquivo de repertório do Comunicantus: Laboratório Coral, que possui obras que já foram utilizadas em diversos perfis de coros e diferentes situações de necessidade de aprendizagem, encontramos no repertório do Coral Escola Comunicantus (grupo que de certa forma inspirou a criação do coro em questão) tal música. Acreditamos que considerar o repertório já utilizado em outros momentos ou mesmo em outros grupos corais pode ser um recurso pedagógico muito eficaz, pois já se conhece diversas questões sobre sua utilização e os procedimentos pedagógicos que foram utilizados para o seu processo de ensino/aprendizagem, e desta forma, a chance de sermos bem sucedidos em nossos objetivos é maior. Então, a escolha de uma música que poderia funcionar num primeiro ensaio foi assim orientada e respaldada por nossos professores.

A primeira obra assim como todo o repertório ${ }^{15}$ escolhido para ser trabalhado ao longo do processo de formação do Coral Oficina Comunicantus (no período em que esta pesquisa foi desenvolvida) passou pelo processo de seleção descrito por Igayara antes de definirmos se seriam utilizadas nos ensaios com o coro.

Para melhor contextualização dos diversos momentos pelos quais passou o coro e compreensão das abordagens e procedimentos utilizados nos ensaios, vamos discorrer sobre o repertório escolhido dividindo o período de nosso trabalho em três semestres.

\footnotetext{
${ }^{14}$ Alunos de graduação de diversas áreas e funcionários da USP, mais detalhado no capítulo 1.3.

${ }^{15}$ As partituras estão em anexo.
} 
Repertório do primeiro semestre de 2008, na ordem em que foi ensaiado:

- Baião de Ninar - Edino Krieger (cânone)

- Duas Cirandas (quodlibet) Arr. Viviane Valladão

- Cantem señores cantores (duas vozes) Arr. Antonio Russo

- O Anel - H. Villa-Lobos (duas vozes)

- Cuca Burra - Marion Sinclair (cânone)

- Minno amor, dexiste ay (três vozes) Anônimo

- Tres Morillas m’enamoram (três vozes) Anônimo

\subsubsection{Baião de Ninar}

Esta peça foi escolhida em uma aula realizada anteriormente ao primeiro ensaio do Coro Oficina pela equipe do Comunicantus: Laboratório Coral, que é realizada semanalmente para tratar de assuntos relativos aos coros, aos alunos em estágio e às atuações pedagógicas utilizadas nos ensaios. Esta peça foi sugerida pelo Prof. Dr. Marco Antonio devido a alguns fatores favoráveis à sua aprendizagem por parte dos novos coralistas, que até aquele momento não se tinha idéia do número de pessoas, gênero, timbre vocal ou qualquer outra informação que pudesse orientar a escolha de uma música para o primeiro ensaio.

Várias são as características da peça que justificam sua utilização com um coro em seu primeiro ensaio, dentre as quais podemos citar as algumas como:

- O texto curto e em português é de fácil aprendizagem;

- Ela foi composta em modo mixolídio, comum na música do nordeste brasileiro com uma sonoridade até próxima das músicas populares que os futuros coralistas supostamente estão acostumados a ouvir;

- Sua tessitura é bastante confortável e adequada para grupos que estão iniciando, está localizada em uma região central para todos os naipes, não ultrapassando uma sétima menor (Dó3 até Sib3), facilitando assim a fixação 
das alturas e o provável pouco conhecimento de técnica vocal dos coralistas, tanto para a execução de notas mais graves ou mais agudas;

Outra questão relevante para sua escolha é o fato desta peça ser um cânone, pois este tipo de composição oportuniza o desenvolvimento da escuta melódica e a execução vocal. Para melhor clareza definiremos esta modalidade de composição musical da seguinte maneira:

Artifício contrapontístico através do qual uma melodia é imitada por uma ou mais vozes nota por nota, do começo ao fim. Princípio de construção: a melodia deve permitir, por suas características internas, ser imitada inteiramente por outras vozes que se superpõem em diferentes "entradas", formando um conjunto consonante. (IGAYARA, 2003, p.)

Assim que aprendem a cantar a música inteira e começam a executar o cânone com suas divisões, a estrutura imitativa da música os faz cantar a melodia enquanto ouvem outras partes da mesma simultaneamente, sua realização plena exige que a concentração dos coralistas aumente de maneira que consigam separar o que estão cantando sem serem influenciados pelo que estão ouvindo. Este é um desafio auditivo, vocal e intelectual que pode levá-los a desenvolver sua escuta melódica, pois trabalha a separação do conteúdo que estão cantando (vocal) daquele que estão ouvindo (auditivo) através da organização mental (intelectual), que divide os dois processos de forma que consigam compreendê-los separadamente e executá-los simultaneamente de maneira consciente, levando a percepção auditiva de outras melodias paralelas a qual estão cantando. Resumindo, um cânone apresenta em sua própria estrutura interna dois diferentes tipos de dificuldades/desafios: primeiro aprender a canção, depois cantá-la sobreposta; ouvir a melodia, ouvir o outro.

No plano de ensaio desta do Baião de Ninar foram escolhidos os seguintes conteúdos freqüenciais (ver pagina):

- Afinação das alturas;

- Cantar intervalos melódicos ascendentes e descendentes;

- Memorização melódica;

- Consciência física corporal da emissão sonora (memória corporal da tessitura); 
- Postura corporal geral do coro;

- Consciência auditiva do próprio som;

- Consciência e compreensão melódica;

- Percepção das outras vozes.

\subsubsection{Duas Cirandas (Folclore do Recife)}

A escolha desta peça, assim como anterior se deu na aula do Comunicantus: Laboratório Coral, de 03 de abril de 2008, um dia após o primeiro ensaio. Nesta aula, depois de ter sido avaliado o ensaio realizado no dia anterior, onde pudemos notar as particularidades físicas, vocais e musicais do grupo, por sugestão do Prof. Marco Antonio optamos em começar o trabalho da música Duas Cirandas, que são melodias folclóricas do Recife, com arranjo de Viviane Valladão em forma de Quodlibet. Devido às características musicais apresentadas pelo grupo, outra peça em português pareceu-nos mais viável de ser trabalhada, para assim podermos direcionar melhor nossa atenção nas questões relativas aos conteúdos musicais. Como um quodlibet esta peça contém apenas duas melodias distintas (embora um quodlibet possa ter diversas melodias), escritas na mesma tonalidade para serem executadas simultaneamente, cada uma por um grupo, de modo que cada grupo cante sua melodia ouvindo a outra simultaneamente. Esta música dá sequêencia ao trabalho iniciado com o cânone Baião de Ninar de Edino Kieger, exigindo ainda mais concentração para domínio vocal, auditivo e intelectual, pelo fato das melodias serem diferentes, inclusive porque o tipo de sobreposição confere uma outra estrutura polifônica à obra, aumentando o grau de dificuldade de sua execução. A tonalidade original do arranjo é Mi menor, mas pelo fato do coro ter apresentado uma tessitura vocal limitada devido a pouca experiência vocal, decidimos ensinar a peça em Ré menor (um tom abaixo) para facilitar a execução das notas mais agudas da peça, aproximando sua tessitura da outra peça ensinada anteriormente, ficando assim entre o Dó\#3 e o Sib3, desta maneira facilitando o trabalho de memorização das alturas trabalhadas nas duas peças melhorando a afinação do coro.

Para o ensaio desta peça foram inicialmente planejados para serem trabalhados os seguintes conteúdos freqüenciais: 
- Afinação das alturas;

- Cantar intervalos melódicos ascendentes e descendentes;

- Memorização melódica;

- Qualidade de afinação dentro dos naipes - afinação das melodias;

- Consciência física da emissão sonora (memória da tessitura);

- Postura corporal geral do coro;

- Consciência auditiva do próprio som;

- Percepção das outras vozes;

- Cantar duas canções diferentes ao mesmo tempo.

- Promover a prática do canto coral a 2 vozes e a habilidade para tanto.

\subsubsection{Canten Señores Cantores}

Na aula seguinte, realizada em 11 de abril do mesmo ano, o ensaio foi avaliado como muito positivo, e mesmo o coro estando em um momento inicial de desenvolvimento, já começava demonstrar bastante facilidade no aprendizado das peças e na realização elementos musicais trabalhados durante os ensaios. Mediante estes fatos, a equipe sugeriu acrescentar uma peça a duas vozes ao conjunto de músicas de nosso repertório até o momento. Sugeri a obra Canten Señores Cantores, vinda do folclore argentino, com arranjo do maestro e compositor Antonio Russo. Esta é uma música de curta duração e com elementos musicais bastante simples. O texto, embora seja em espanhol, é bastante curto e de fácil memorização, sendo que a maior parte está concentrada no trecho das vozes agudas e nas vozes graves é de apenas uma frase, fazendo assim com que pudéssemos direcionar melhor o enfoque para o trabalho musical. Outro aspecto interessante do texto é o fato dele ser distinto nas duas vozes durante quase toda a música sendo igual que apenas na última frase, o que nos levou a considerá-lo adequado para o estágio de desenvolvimento musical do coro naquele momento, e desta forma podendo facilitar a junção dos dois naipes na hora do ensaio geral, ajudando assim a desenvolver a consciência e a escuta melódicas.

Com relação à tessitura geral da peça, a primeira voz vai do Dó3 ao Mib4, fato que indica a nossa tentativa de ampliar o alcance vocal das mulheres (grupo escolhido para cantar a primeira voz). Já a segunda voz, executada pelos naipes masculinos, a tessitura vai do Sib2 
ao Sol3, conduzindo os homens para uma região vocal um tom abaixo da que cantavam nas duas primeiras obras. A forma em que a peça está disposta pode facilitar para cada naipe conseguir cantar sua voz prestando atenção à outra executada conjuntamente pelo outro naipe, de maneira que os coralistas não sejam influenciados pela escuta da voz do naipe vizinho, dando maior oportunidade ao desenvolvimento da escuta melódica e, conseqüentemente, a afinação das melodias simultâneas, tanto no aspecto horizontal quanto no vertical. Nesse sentido destacamos a textura da segunda voz que é composta por seqüências rítmicas bem delineadas, destacando-se assim em relação a primeira voz constituindo um elemento bastante importante para auxiliar na diferenciação entre as duas linhas pelos coralistas.

Para o ensaio desta peça foram inicialmente planejados para serem trabalhados os seguintes conteúdos freqüenciais:

- Afinação das alturas;

- Cantar intervalos melódicos ascendentes e descendentes;

- Memorização melódica;

- Manutenção da afinação ao longo da peça;

- Qualidade de afinação dentro dos naipes - afinação das melodias;

- Qualidade de afinação entre os naipes - afinação das simultaneidades;

- Consciência física da emissão sonora (memória da tessitura);

- Postura corporal geral do coro;

- Consciência auditiva do próprio som;

- Cantar duas melodias diferentes simultaneamente;

- Percepção das outras vozes;

- Promover a prática do canto coral a 2 vozes e a habilidade para tanto.

\subsubsection{O Anel (Duas vozes)}

A escolha desta peça para ser ensaiada com o Coral Oficina se deu por causa de diversos elementos musicais que ela oferece para serem trabalhados com os coralistas. 
Considerando o fato de que estávamos procurando uma peça a duas vozes para continuar o trabalho de desenvolvimento de escuta paralela dos coralistas, de forma que este fator não influenciasse a execução da melodia que estão cantando. A peça deveria estar escrita dentro de uma tessitura próxima a que o grupo conseguia cantar naquele momento de sua escolha, para assim utilizarmos elementos por eles conhecidos com o objetivo de alcançar maior qualidade de afinação das vozes e na percepção das melodias trabalhadas. E a música $O$ Anel, melodia popular brasileira, que remete a brincadeira conhecida como passa anel, com o seu arranjo escrito por Heitor Villa-Lobos oferece bem mais do que isso. Escrita na tonalidade de Mi bemol maior, sua tessitura geral esta situada da seguinte forma: na segunda voz atinge do Sib2 ao Sol3 e na primeira voz do Mib3 ao Dó4, região vocal onde o coro em questão não apresentava dificuldades de entonação por se tratar de regiões já exploradas nos outros ensaios. Esta peça foi elaborada pelo compositor em uma estrutura de pergunta e resposta, procedimento composicional que facilita que cada naipe escute a melodia do outro antes de cantar. Vejamos a seguir, o trecho extraído dessa música:

1
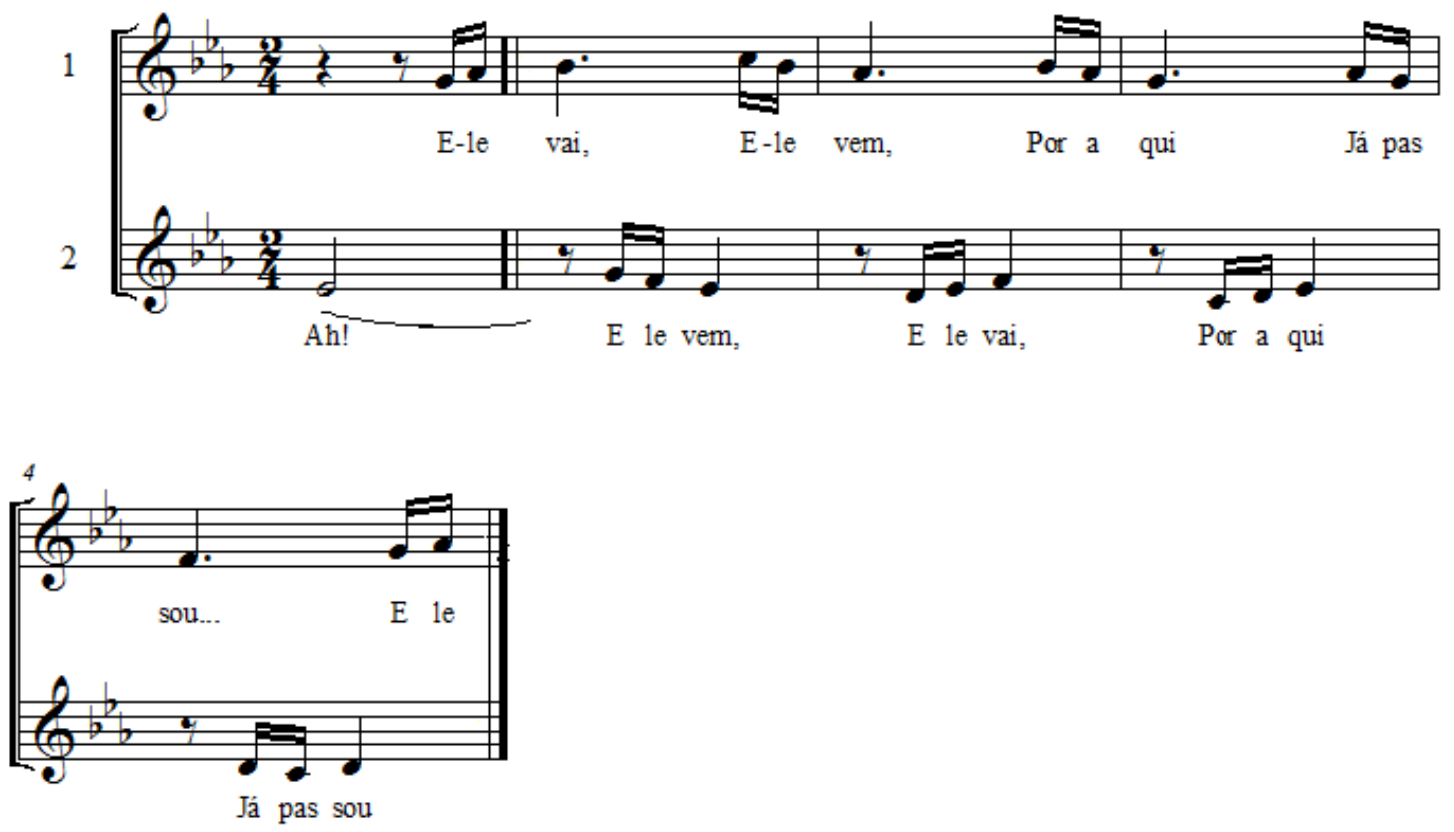

Podemos observar na figura acima, que a música inicia pela segunda voz com uma nota parada, e a primeira voz inicia na segunda metade do segundo tempo do mesmo compasso. Quando começa o segundo compasso ela logo executa uma nota parada para a segunda voz responder cantando outro motivo. Este procedimento ocorre até o compasso cinco onde cessam as notas paradas e o procedimento de pergunta e resposta fica mais 
imediato levando a uma idéia de maior velocidade, sendo retomado o procedimento de nota longa alternada entre as vozes no compasso nove (na casa I). Este procedimento de uma voz cantar nota longa enquanto a outra canta um motivo de maneira alternada entre elas pode levar os coralistas a desenvolver sua escuta melódica, sua afinação e sua precisão rítmica, pois facilita que cada grupo possa ouvir a melodia do outro sem receber influência da mesma. O fato de vários motivos melódicos nas duas vozes serem compostos com intervalos diatônicos descendentes foi outro elemento a ser trabalhado, pois os integrantes do coro já vinham apresentando necessidade de aprendizagem para cantar linhas descendentes. Também foi de interesse pedagógico ensinar conteúdos de teoria musical como as barras duplas, ritornelos, ligaduras, segno e casas I e II dentre diversos outros elementos contidos nesta peça.

Para o ensaio desta peça foram inicialmente planejados para serem trabalhados os seguintes conteúdos freqüenciais:

- Afinação das alturas;

- Cantar intervalos melódicos ascendentes e descendentes;

- Memorização melódica;

- Manutenção da afinação ao longo da peça;

- Qualidade de afinação dentro dos naipes - afinação das melodias;

- Qualidade de afinação entre os naipes - afinação das simultaneidades;

- Consciência física da emissão sonora (memória corporal da tessitura);

- Postura corporal geral do coro;

- Consciência auditiva do próprio som;

- Cantar duas melodias diferentes simultaneamente;

- Percepção das outras vozes;

- Desenvolver a escuta melódica consciente;

- Promover a prática do canto coral a 2 vozes e a habilidade para tanto. 


\subsubsection{Cuca Burra}

Agora o coro já estava cantando quatro músicas. Um cânone (Baião de Ninar), um quodlibet (Duas Cirandas) e duas peças a duas vozes (Cantem Señores Cantores e O Anel). Então a equipe pensou em começar a preparar o coro para aprender a cantar uma peça a três vozes. Decidimos então trabalhar o cânone Cuca Burra, melodia composta por Marion Sinclair na Austrália, pode ser cantada em até três grupos por causa de sua disposição estrutural, que em alguns momentos forma acordes maiores, resultando em uma harmonia a três vozes, iniciando assim a preparação auditiva, vocal e intelectual do coro para essa modalidade de repertório.

Trata-se de uma obra composta com apenas oito compassos, dentro da tonalidade de Dó maior iniciando na região da dominante, passando pela dominante relativa e terminando na tônica. Sua tessitura é de apenas uma oitava, indo do Dó3 ao Dó4, região a qual o coro já estava bastante acostumado a cantar, facilitando muito a afinação e a memorização das alturas. As seqüências intervalares são bem simples tendo como desafio apenas um salto de oitava ascendente, constituindo um novo elemento de aprendizagem melódica. O texto em italiano é bastante simples, facilitando assim sua memorização e possibilitando maior atenção aos elementos musicais.

Para o ensaio desta peça foram inicialmente planejados para serem trabalhados os seguintes conteúdos freqüenciais:

- Afinação das alturas;

- Cantar intervalos melódicos ascendentes e descendentes;

- Memorização melódica;

- Manutenção da afinação ao longo da peça;

- Qualidade de afinação dentro dos naipes - afinação das melodias;

- Qualidade de afinação entre os naipes - afinação das simultaneidades;

- Consciência física da emissão sonora (memória corporal da tessitura);

- Postura corporal geral do coro;

- Consciência auditiva do próprio som;

- Consciência de sua nota na harmonia;

- Consciência e compreensão melódica;

- Percepção das outras vozes. 


\subsubsection{Minno amor, dexiste ay}

Esta foi a primeira peça a três vozes diferentes trabalhada com o grupo do Coral Oficina Comunicantus. Utilizando o mesmo processo realizado sistematicamente pela equipe do Comunicantus: Laboratório Coral, escolhemos uma peça curta com pouco texto para priorizar o trabalho musical. Está música é um villancico pertencente ao Cancionero de Palacio. De compositor desconhecido, escrita na tonalidade de Dó maior e com texto em idioma galaico português. Seu ritmo é simples e sua estrutura de caráter quase homofônico com poucas variações rítmicas entre as vozes. Por se tratar de uma canção estrófica, facilitou a memorização das melodias por parte dos naipes, pois mudavam apenas o texto. Seus elementos estruturais facilitam a aprendizagem das alturas, principalmente por terminar todas as frases com os naipes cantando combinações de uníssonos e oitavas, trazendo sempre a questão da afinação e ressonância à memória dos cantores. Na primeira voz sua tessitura vai do Do3 ao Lá3, na segunda voz do Sol3 ao Dó4 e na terceira voz, a mais grave, do Sol1 ao Sol2, desta forma trabalhando sempre com extensões pequenas facilitando a entoação e a afinação das vozes. As frases melódicas muito curtas, sempre com quatro compassos, contribuíram muito para o coro aprender a peça rapidamente. Com um desenho melódico simples nas duas vozes superiores, utilizando-se em sua maioria de saltos diatônicos, somente na terceira voz os saltos são mais constantes, principalmente os de quinta justa, constituindo um ótimo desafio para a afinação dos graves do coro.

Para o ensaio desta peça foram inicialmente planejados para serem trabalhados os seguintes conteúdos freqüenciais:

- Afinação das alturas;

- Cantar intervalos melódicos ascendentes e descendentes;

- Percepção e capacidade de emissão dos cromatismos;

- Memorização melódica;

- Correção e qualidade na realização dos fraseados da música;

- Manutenção da afinação ao longo da peça;

- Qualidade de afinação dentro dos naipes - afinação das melodias;

- Qualidade de afinação entre os naipes - afinação das simultaneidades;

- Consciência física da emissão sonora (memória da tessitura); 
- Postura corporal geral do coro;

- Consciência auditiva do próprio som;

- Consciência de sua nota na harmonia;

- Consciência e compreensão melódica;

- Cantar três melodias diferentes simultaneamente;

- Percepção das outras vozes;

- Promover a prática do canto coral a 3 vozes e a habilidade para tanto.

\subsubsection{Tres Morillas m'enamoram}

A peça anterior foi a que o coro demorou mais tempo para assimilar musicalmente. O processo de escuta a três vozes obrigou aos monitores esperarem um pouco antes de iniciar a aprendizagem de uma nova peça. Após um mês de ensaio de trabalho com todas as obras ensaiadas até então, chegou o momento de colocarmos uma música nova pro grupo. Com um desafio diferente do que foi colocado até então. Chegara o momento de exigir mais da memória musical e melódica dos coralistas. Por este motivo, a equipe do Comunicantus: Laboratório Coral, depois da leitura de algumas peças decidiu incluir no repertório trabalhado do Coral Oficina Tres Morillas m'enamoram, outra música a três vozes de compositor desconhecido e também pertencente ao Cancioneiro de Palácios. Composta em idioma espanhol arcaico, as melodias de cada voz já tem um caráter mais diversificado, pois se trata de vozes com uma construção contrapontística mais elaborada, com utilização de movimentos contrários entre as vozes, obrigando assim cada voz a não depender da escuta da outra, sem apoios harmônicos, e em alguns momentos até com soluções composicionais polifônicas e ornamentos na segunda voz.

A tessitura na primeira voz vai do Lá2 ao Lá3, na segunda voz do Mi3 ao Mi4, e na terceira voz do Lá1 ao Lá2, ou seja, cada naipe tem a tessitura exata de uma oitava, ajudando na memorização das alturas e da região vocal. A maior dificuldade nesta peça é a manutenção da afinação de cada voz simultaneamente com as outras, pois, por causa de maneira que foi escrita, há uma sucessão de acordes maiores e menores que se alternam durante a peça, e manter estes acordes afinados através da execução melódica das vozes é um desafio bastante complexo, pois lida com a escuta melódica e a sensação harmônica simultaneamente. 
Para o ensaio desta peça foram inicialmente planejados para serem trabalhados os seguintes conteúdos freqüenciais:

- Afinação das alturas;

- Cantar intervalos melódicos ascendentes e descendentes;

- Percepção e capacidade de emissão dos cromatismos;

- Memorização melódica;

- Correção e qualidade na realização dos fraseados da música;

- Manutenção da afinação ao longo da peça;

- Qualidade de afinação dentro dos naipes - afinação das melodias;

- Qualidade de afinação entre os naipes - afinação das simultaneidades;

- Consciência física da emissão sonora (memória da tessitura);

- Postura corporal geral do coro;

- Consciência auditiva do próprio som;

- Consciência de sua nota na harmonia;

- Consciência e compreensão melódica;

- Cantar três melodias diferentes simultaneamente;

- Percepção das outras vozes.

Repertório do segundo Semestre de 2008, na ordem em que foi ensaiado:

Para melhor compreensão do trabalho realizado pela equipe de alunos orientados com o Coral Oficina é necessário fazer alguns esclarecimentos sobre o grupo de coralistas a ele integrados.

Com o final do semestre e o encerramento dos ensaios, aguardávamos ansiosos como seria o retorno das pessoas no segundo semestre, pois é comum no ambiente universitário haver mudança dos horários das disciplinas na passagem de um semestre para outro, desta maneira, pelo fato da maioria de nossos coralistas serem estudantes da USP, sabíamos da possibilidade de vários dos integrantes não poderem retornar, assim também como poderiam entrar novos coralistas com os quais seria necessário fazer um trabalho que 
os deixassem com um nível musical que possibilitasse o acompanhamento dos membros mais antigos do grupo. E foi o que de certa forma aconteceu, o número de pessoas que não retornaram foi bastante considerável, e os novos que procuram o coro foram em quantidade bastante reduzida, fato este que mudou bastante a seqüência do trabalho. Tivemos que retomar várias das peças já trabalhadas e demorou mais tempo do que o planejado para seguirmos com o trabalho a partir do ponto que havíamos chegado ao final do primeiro semestre, por este motivo e por outras necessidades de aprendizagem apresentadas pelo novo grupo, só integramos ao repertório trabalhado mais duas obras:

- El Ciodo del ferro Vecio

- Medieval Glória

Desta forma durante quase todo o semestre foi utilizada uma abordagem que visa igualar em desenvolvimento os novos participantes com os poucos já integrados, por isso, retomamos todo o repertório que foi utilizado nos ensaios realizados anteriormente. Fruto desta atitude perante a situação que se configurou, que é bastante natural no ambiente de formação coral e é definida por Ramos em sua Dissertação de Mestrado como Ciclo ou Giro. Vejamos:

No Brasil, a maioria dos corais tem um ciclo. Entendemos ciclo como um processo onde um certo número de cantores se forma como grupo, fixa-se junto a um determinado coral, desenvolve com o regente um certo trabalho até um ponto apicial e depois se rompe de forma brusca ou entra gradualmente em decadência. (RAMOS, 1988, p. 23 e 24)

Notamos aqui que o primeiro ciclo do Coral Oficina Comunicantus chegou a seu final juntamente com o encerramento do semestre, e para nos aproximar do resultado que havíamos atingido anteriormente se fez necessário abordar novamente aspectos já desenvolvidos com parte do coro, mas não ainda com os demais. Como acabamos por trabalhar todas as obras ensina no primeiro semestre, quando chegou o momento do coro participar de uma apresentação pública, escolhemos uma peça que já estivesse mais bem dominada, no caso a música foi Duas Cirandas, que durante todo o período em que foi trabalhada pelo aluno regente Renato seus elementos serviram como grande fonte de aspectos 
para o desenvolvimento das necessidades de aprendizagem dos coralistas. Apresentada juntamente com o Coral Escola Comunicantus no dia 07 de dezembro deste ano, no Grande Auditório do MASP em São Paulo, encerrando assim as atividades do segundo semestre.

\subsubsection{El Ciodo del ferro Vecio}

Esta peça foi escolhida para iniciar os trabalhos do Coral Oficina Comunicantus no segundo semestre de 2008. Devido ao fato de não sabermos quantos dos coralistas que haviam participado do Coral Oficina no primeiro semestre retornariam após o período de férias, decidimos em aula trabalhar esta peça, já trabalhada em outros grupos ${ }^{16}$ do Laboratório Coral, para retornar aos ensaios.

Música de compositor desconhecido vinda do folclore tradicional da região do Veneto na Itália com o texto no dialeto correspondente. É uma composição em forma de cânone e está na tonalidade de Fá maior, e é formada por duas melodias curtas com texto simples, facilitando sua memorização. A tessitura é de apenas uma oitava, indo do Dó3 ao Dó4, e possui diversos elementos musicais trabalhados nas peças aprendidas no semestre anterior, o que poderia ajudar a retomar os conteúdos trabalhados com os coralistas antigos, e começar a desenvolver com os novos os aspectos mesmos trabalhados.

Para o ensaio desta peça foram inicialmente planejados para serem trabalhados os seguintes conteúdos freqüenciais:

- Afinação das alturas;

- Cantar intervalos melódicos ascendentes e descendentes;

- Memorização melódica;

- Manutenção da afinação ao longo da peça;

- Qualidade de afinação dentro dos naipes - afinação das melodias;

- Consciência física da emissão sonora (memória da tessitura);

- Postura corporal geral do coro;

- Consciência auditiva do próprio som;

\footnotetext{
${ }^{16}$ Coral Escola Comunicantus.
} 
- Consciência e compreensão melódica;

- Percepção das outras vozes;

- Recuperar conteúdos e habilidades trabalhadas no semestre anterior.

\subsubsection{Medieval Glória}

Após a conclusão da reformulação dos participantes do Coral Oficina Comunicantus, causada pela mudança dos horários nos cursos de graduação no segundo semestre da USP, a equipe de alunos orientados trabalhou durante dois o repertório visto até então para que os novos coralistas juntamente com os antigos atingissem o desenvolvimento necessário para poder continuar o processo de desenvolvimento musical do grupo. Foram discutidos e utilizados diversos procedimentos pedagógicos e didáticos ${ }^{17}$ para que este objetivo fosse alcançado. Neste momento, por sugestão da aluna regente Caiti Hauck e com aprovação da Professora Susana Igayara, escolheu-se trabalhar a peça Medieval Glória, do compositor Vijay Singh. Está escrita com a estrutura do modo Dórico no tom de Mi bemol, onde o compositor escreve a segunda voz utilizando a estrutura original da peça, quase toda a duas vozes, alternando trechos homofônicos e polifônicos (procedimento composicional conhecido como pergunta e resposta), variando somente no compasso final quando o coro é dividido em quatro vozes. Tem diversos elementos de difícil execução com intervalos harmônicos de quinta justa em alguns trechos, momentos de solo de naipe, procedimento imitativo e acompanhamento de percussão com ritmo invertido ao cantado pelo coro.

Para o ensaio desta peça foram inicialmente planejados para serem trabalhados os seguintes conteúdos freqüenciais:

- Afinação das alturas;

- Fraseado;

- Cantar intervalos melódicos ascendentes e descendentes;

- Percepção e capacidade de emissão dos cromatismos;

- Memorização melódica;

\footnotetext{
${ }^{17}$ Este assunto será abordado no capítulo 3.
} 
- Correção e qualidade na realização dos fraseados da música;

- Manutenção da afinação ao longo da peça;

- Qualidade de afinação dentro dos naipes - afinação das melodias;

- Qualidade de afinação entre os naipes - afinação das simultaneidades;

- Consciência física da emissão sonora (memória da tessitura);

- Postura corporal geral do coro;

- Consciência auditiva do próprio som;

- Consciência de sua nota na harmonia;

- Consciência e compreensão melódica;

- Cantar duas melodias diferentes simultaneamente;

- Percepção das outras vozes;

- Promover a prática do canto coral a 2 e 4 vozes e a habilidade para tanto.

Repertório do primeiro Semestre de 2009, na ordem em que foi ensaiado:

Este período de retorno aos ensaios foi bastante importante, pois após um ano de trabalho, a mudança do local dos ensaios que inicialmente aconteciam na sala 300 do bloco $\mathrm{E}$ do Conjunto Residencial da USP e desde setembro de 2008 transferiu-se para o Departamento de Música da ECA-USP, a repercussão da apresentação do coro no MASP e o trabalho de divulgação da equipe do Comunicantus: Laboratório Coral atraiu um grande número de pessoas interessadas em integrar o Coral Oficina Comunicantus. Fato que deixou a todos da equipe muito animados, mas que levou a retomarmos o processo de desenvolvimento dos aspectos musicais. O repertório ensaiado neste período foi o seguinte:

- Viva la Musica - Michael Praetorius (cânone)

- Na Bahia tem - Folclore - Arr: Orlando leite

- Ponta de areia - M. Nascimento e F. Brant - Arr: M. Ramires e C. N. Pinto

- Rodrigo Martinez - Anônimo - Ed. Felipe Fonseca 


\subsubsection{Viva la Musica}

Esta obra foi escolhida para reiniciar o trabalho de forma que poderíamos avaliar qual era a condição musical dos coralistas. Imaginávamos que receberíamos novos coralistas e este tipo de peça ajuda a avalizar diversas habilidades dos coralistas como, por exemplo:

- Afinação das alturas;

- Cantar intervalos melódicos ascendentes e descendentes;

- Percepção e capacidade de emissão dos cromatismos;

- Memorização melódica;

- Correção e qualidade na realização dos fraseados da música;

- Manutenção da afinação ao longo da peça;

- Qualidade de afinação dentro dos naipes - afinação das melodias;

- Qualidade de afinação entre os naipes - afinação das simultaneidades;

- Consciência física da emissão sonora (memória da tessitura);

- Consciência auditiva do próprio som;

- Consciência e compreensão melódica;

- Percepção das outras vozes.

Escrita na tonalidade de Sol maior sendo que sua tessitura iniciando com o Dó3 até o Ré4. Sua estrutura a três vozes permite o trabalho de aspectos como melodia descendente, afinação de acordes, no caso Sol maior e Ré maior dentre outras combinações ao longo da música, possibilitando a análise de diversas necessidades de aprendizagem dos coralistas. Outra questão considerada foi o texto curto e em espanhol que poderia direcionar toda a atenção das pessoas nos aspectos musicais. 


\subsubsection{Na Bahia tem}

A partir dos resultados obtidos nos três primeiros ensaios do ano percebemos que já era chegado o momento de trabalharmos uma obra a quatro vozes. Esta peça foi escolhida inicialmente por já ter feito parte do repertório do Coral Escola Comunicantus e ter oferecido a este grupo, uma grande oportunidade de aprendizagem de diversos conteúdos musicais. Escrita na tonalidade de Ré maior ela possibilita ao regente trabalhar como o coro o desenvolvimento da escuta melódica de uma maneira marcante. Sua tessitura passa pelas seguintes notas: sopranos do Ré3 ao Ré4, contraltos do Lá2 ao Lá3, tenores do Fá2 ao Fá3 e baixos do Lá1 ao Fá\#2.

A peça inicia pelo naipe de contraltos que é respondida pelos baixos logo em seguida no segundo compasso, a partir do terceiro sopranos e tenores entram cantando juntos as mesmas notas (cada qual na sua oitava) confirmando o tema e completando a harmonia. A partir do compasso cinco, os naipes femininos têm o mesmo texto que cantam formando intervalos de terça até fazerem um uníssono no compasso oito, procedimento que se repete entre os compassos nove a doze. No mesmo trecho os baixos executam o procedimento de cantar sempre uma quinta descendente e uma quarta ascendente sustentando a harmonia, e os tenores realizam movimento cromático descendente. A partir do trecho "cantarolando" os naipes femininos voltam a cantar em intervalos de terça modificando apenas nos dois últimos compassos, os tenores por sua vez executam uma melodia que reponde a contraltos e sopranos e os baixos mantêm a sustentação canto as notas ré e lá com pouca variação rítmica contrastando com os outros naipes.

Ao observamos esta partitura ${ }^{18}$ podemos constatar quão rico é o material que oferece para ser desenvolvido com os coralistas. No ponto de vista do desenvolvimento dos aspetos freqüênciais e melódicos pontuamos os seguintes:

- Afinação das alturas;

- Fraseado;

- Cantar intervalos melódicos ascendentes e descendentes;

${ }^{18}$ Consta entre os anexos. 
- Percepção e capacidade de emissão dos cromatismos;

- Memorização melódica;

- Correção e qualidade na realização dos fraseados da música;

- Manutenção da afinação ao longo da peça;

- Qualidade de afinação dentro dos naipes - afinação das melodias;

- Qualidade de afinação entre os naipes - afinação das simultaneidades;

- Consciência física da emissão sonora (memória da tessitura);

- Consciência auditiva do próprio som;

- Consciência de sua nota na harmonia;

- Consciência e compreensão melódica;

- Percepção das outras vozes;

- Promover a prática do canto coral a 4 vozes e a habilidade para tanto.

\subsubsection{Ponta de areia}

Da mesma forma que a peça $\mathrm{Na}$ Bahia tem esta música também fez parte do repertório do Coral escola Comunicantus. Escrita na tonalidade de Sol maior os naipes cantam dentro da seguinte tessitura: sopranos do Mi3 ao Fá\#4, contraltos do Si2 ao Lá3, tenores do Mi2 ao Ré3 e baixos do Sol1 ao Sol2. A disposição das vozes possibilita aos coralistas que escutem as simultaneidades entre os naipes, nos primeiros compassos a peça inicia com os naipes masculinos realizando procedimento de pergunta e resposta, com baixo cantando sempre a mesma nota (Ré2) e o tenor cantando quarta e quinta justas acima. A partir do compasso cinco o contralto começa a cantar junto com o tenor formando intervalos de terça acima das notas entoadas por eles. No compasso nove, o naipe de sopranos começa a cantar a melodia sobre a harmonia realizada pelos outros naipes. Além do aperfeiçoamento dos conteúdos trabalhados na peça Na Bahia tem, esta música oferece um desafio diferente que é uma melodia que caminha entre os naipes, ela é mantida pelos sopranos até o compasso dezoito, no compasso seguinte passa para os baixos, no vinte e um é entoada pelos tenores, no vinte e cinco volta para sopranos, no trinta e dois passa para contraltos, volta para sopranos no trinta e sete, e assim, vão ocorrendo mudanças entre os naipes até o fim da peça. Este recurso 
de composição faz com que se desenvolva a escuta melódica dos coralistas, pois sua concentração deve ser mantida ao longo de toda a obra, qualquer distração pode comprometer a qualidade da performance do coro.

Pontuamos os seguintes aspectos freqüênciais e melódicos contidos nesta obra para serem desenvolvidos com o coro:

- Afinação das alturas;

- Fraseado;

- Cantar intervalos melódicos ascendentes e descendentes;

- Percepção e capacidade de emissão dos cromatismos;

- Memorização melódica;

- Correção e qualidade na realização dos fraseados da música;

- Manutenção da afinação ao longo da peça;

- Qualidade de afinação dentro dos naipes - afinação das melodias;

- Qualidade de afinação entre os naipes - afinação das simultaneidades;

- Consciência física da emissão sonora (memória da tessitura);

- Postura corporal geral do coro;

- Consciência auditiva do próprio som;

- Consciência de sua nota na harmonia;

- Consciência e compreensão melódica;

- Percepção das outras vozes;

- Promover a prática do canto coral a 4 vozes e a habilidade para tanto.

- Entradas subseqüentes.

\subsubsection{Rodrigo Martinez}

Esta peça foi escolhida em um contexto determinado, pois com o início do trabalho a quatro vozes, reapareceram diversas questões de aprendizagem que ainda não estavam completamente desenvolvidas, sentimos a necessidade de uma música através da qual pudéssemos retomar e expandir a abordagem dos seguintes pontos: 
- Afinação das alturas;

- Memorização melódica;

- Correção e qualidade na realização dos fraseados da música;

- Manutenção da afinação ao longo da peça;

- Consciência física da emissão sonora (memória da tessitura);

- Postura corporal geral do coro;

- Consciência auditiva do próprio som;

- Consciência e compreensão melódica;

- Habilidade de cantar melodia em uníssono;

- Habilidade de cantar acompanhados por instrumentos diversos.

Desta maneira o Prof. Marco Antonio juntamente com a Prof. a Susana sugeriram trabalhar a melodia desta canção advinda do Cancionero de Palacio para utilizarmos como apoio para as outras canções. Sua tessitura é bastante pequena sendo do Ré3 ao Lá3 para os naipes agudos e Ré2 ao Lá2 para os graves, com apenas uma quinta utilizando somente notas naturais, dando a idéia de uma tonalidade menor facilitando sua memorização. A montagem unindo o coro para cantar em uníssono a voz mais aguda e destinando o baixo para os instrumentos executarem. Esta música apresentou novas dificuldades rítmicas e melódicas para o grupo e, por causa disto, foi preciso trabalhar novamente a habilidade de todos cantarem a mesma melodia de maneira afinada, Ramos (2010, citação verbal) diz: “Às vezes é preciso dar um passo para trás para depois seguir em frente” (Informação Verbal) ${ }^{19}$. Por causa deste pensamento optamos por realizar tal abordagem apoiada por instrumentos musicais, para tal foram escolhidos o trombone (instrumento principal do aluno regente Filipe que fez o arranjo) e o violão (que fazia o papel do contínuo).

Todas as peças ensaiadas ao longo do tempo em que este trabalho foi realizado foram regidas por diferentes alunos ${ }^{20}$ integrados ao Comunicantus: Laboratório Coral. Para melhor clareza desse fato relaciono a seguir os nomes desses alunos e as respectivas peças que dirigiram nos ensaios:

\footnotetext{
${ }^{19}$ RAMOS, Marco A. da S. Comentário de aula na disciplina Práticas multidisciplinares em canto coral com estágio supervisionado da USP, São Paulo, ago, 2009.

${ }^{20}$ Conforme poderemos comprovar no capitulo 3 .
} 
$\checkmark$ Caiti Hauck: O Anel - H. Villa-Lobos (duas vozes)

Minno amor, dexiste ay (três vozes) Anônimo

Medieval Glória (Duas vozes) - Vijay Singh

Viva la Musica - Michael Praetorius (cânone)

Rodrigo Martinez - Anônimo - Ed. Felipe Fonseca

$\checkmark$ Márcio Ocon: Tres Morillas m’enamoram (três vozes) Anônimo

$\checkmark$ Isaac Terceros: El Ciodo del ferro Vecio (cânone)

$\checkmark$ Paulo Lopes: Baião de Ninar - Edino Krieger (cânone)

Cantem Señores Cantores (duas vozes) Arr. Antonio Russo

Cuca Burra - Marion Sinclair (cânone)

$\checkmark$ Renato Spinosa: Duas Cirandas (quodlibet) Arr. Viviane Valladão

Ponta de areia - M. Nascimento e F. Brant - Arr: M. Ramires e C. N. Pinto

$\checkmark$ Rodrigo Báez: Na Bahia tem - Folclore - Arr: Orlando leite 
3. Relatórios de Avaliação dos Ensaios do Coral Oficina e as Análises dos Procedimentos

O Comunicantus: Laboratório Coral tem como método de documentação do seu trabalho planejamentos e avaliações de ensaio redigidas por seus monitores a partir dos quais são feitas discussões a respeito do andamento do processo de desenvolvimento dos coros a ele integrados. Nossas análises foram realizadas através do conteúdo desses documentos assim como de nossas observações efetuadas em situações específicas do Coral Oficina Comunicantus, onde detectamos as necessidades de aprendizagem que estão diretamente relacionadas ao desenvolvimento de sua escuta melódica, necessidades essas que foram apresentadas pelos coralistas durante os ensaios ocorridos entre os meses de abril de 2008 e maio de 2009. A escolha dos ensaios relatados foi feita levando em conta o conteúdo que se pretende abordar nesta investigação, e assim como o nível de desenvolvimento em que o coro estava no determinado momento. Elas estão descritas a seguir com o intuito de documentar o pensamento pedagógico e as soluções obtidas a partir de um processo analítico construtivo que trabalhou interferindo com ações didáticas, avaliando seus resultados e, a partir deles, escolhendo qual a melhor forma ou formas de continuar o processo de ensino/aprendizagem do coro. As análises dessas avaliações dos ensaios também servirão para arrazoarmos o desenvolvimento dos coralistas durante o processo de aprendizagem do coro, assim como nortear nossas ponderações sobre os conteúdos aprendidos e os ainda a se aprender.

É muito mais difícil avaliar a compreensão de um conceito ou princípio do que medir a aprendizagem de conteúdos factuais. De modo geral, pode-se dizer que um conceito foi aprendido quando se sabe utilizá-lo nas mais diversas situações em que ele se aplica, ou seja, na interpretação, na compreensão ou na exposição dos fenômenos da realidade aos quais ele se refere. (COSTA, 2005, p. 20)

Considerando este pensamento, as observações do resultado da performance dos coralistas ao longo dos ensaios nos apontarão os procedimentos a serem adotados. Sendo assim, em muitos casos abordaremos aspectos não mencionados pelos monitores responsáveis pelas avaliações, pois além desta fonte também serão aludidos outros aspectos, pois estivemos presentes em todos os ensaios e analisei pontos distintos do avaliador, voltados geralmente para as preocupações deste trabalho e não necessariamente para os objetivos imediatos do ensaiador de cada peça musical de nosso repertório. Por isso, embora 
no corpo deste trabalho o tratamento das ações realizadas por esse pesquisador esteja quase sempre em terceira pessoa, ao citar exemplos ou experiências de minha vivência ou interferências pessoais que foram realizadas junto ao coro estarão então em primeira pessoa. Neste capítulo não discutirei prováveis soluções para as necessidades do coro, apenas as pontuarei, e as atividades pedagógicas desenvolvidas para este fim serão tratadas no capitulo 4- Desenvolvimento de atividades pedagógicas com objetivo de construir a escuta melódica.

$1^{\circ}$ Semestre de 2008

\subsection{Avaliação de 02/04/2008}

Esta avaliação se refere ao primeiro ensaio do Coral Oficina Comunicantus, e para obter uma melhor visibilidade dos dados coletados em nossa análise, vamos transcrever integralmente o texto desse relatório mantendo inclusive algumas perguntas que compõem a ficha de avaliação padrão para os monitores. O que ficou como responsável pela avaliação desse ensaio foi o aluno regente Renato Martins de Oliveira Spinosa ${ }^{21}$, que assim discorre sobre o ensaio:

- Os objetivos do ensaio foram atingidos?

Sim, já que os objetivos planejados para este ensaio eram poucos. Tinham-se como meta a recepção dos novos cantores, esclarecer o funcionamento do projeto e, se possível, um primeiro ensaio do cânone Baião ${ }^{22}$, para que se tivesse noção do nível de musicalidade do novo grupo.

- Houve alguma modificação nas atividades previstas para o ensaio? Por não ter tido um planejamento formal prévio, também não houve modificação.

\footnotetext{
${ }^{21} \mathrm{Na}$ convenção dos termos dos relatórios do Comunicantus, aluno regente refere-se ao que de fato está no papel em uma ou mais músicas naquele ensaio, todos os outros são monitores.

${ }^{22}$ Baião de Ninar de Edino Kriger.
} 
- Como você avalia o resultado geral do ensaio?

Bom, na medida do possível. É necessário que se considere que foi o primeiro contato com os cantores, e eles têm como perfil (ao menos no ideário) serem cantores sem experiência.

Após certo transtorno por não ser possível realizar o ensaio na sala prevista, ele acabou por começar com aproximadamente 10 minutos de atraso.

Os professores Marco Antonio e Susana fizeram esclarecimentos a respeito do funcionamento do projeto, os cantores preencheram fichas de inscrição e às 18:35 foi feita uma primeira audição com todos os cantores juntos e misturados (homens e mulheres).

O primeiro vocalize foi coordenado pelo mestrando regente ${ }^{23}$ Paulo Lopes acompanhado ao piano pelo aluno regente Isaac. Ele foi feito em boca chiusa em grau conjunto (ascendente e descendente) com a distância de uma terça maior sem muito sucesso.

Logo após separou-se o coro em homens e mulheres e ainda em boca chiusa foi feito o mesmo exercício, porém desta vez com a distância de uma quinta justa. Os homens se revelaram mais afinados que as mulheres, que mesmo assim já apresentaram sinais de melhora na afinação.

Às 18:58 o aluno-regente Paulo começou o ensaio do cânone Baião, cantando sozinho por partes de 2 a 3 vezes até que os cantores eram requisitados a repetir.

Depois de aprendida a melodia até o final, os cantores foram conduzidos a entoar o cânone a duas vozes (homens e mulheres). As duas primeiras vezes com o naipe feminino entrando primeiro e por fim com as entradas invertidas, (leia-se o naipe masculino entrando primeiro).

Em algumas tentativas, não se obteve sucesso devido à segunda voz, que se atrasava na entrada ao repetir cânone. Isso aconteceu também quando a ordem das entradas foi invertida.

Apesar disso, na maioria das vezes em que se realizou, o cânone foi executado com sucesso.

Às 19:10 os coralistas foram dispensados recebendo mais uma vez as boas vindas ao novo grupo formado.

\footnotetext{
${ }^{23} \mathrm{Na}$ convenção dos termos dos relatórios do Comunicantus, mestrando regente refere-se ao que de fato está no papel em uma ou mais músicas naquele ensaio.
} 
Análise do ensaio:

O ensaio teve início com a apresentação dos coralistas, este ponto é muito importante, pois as relações estabelecidas pelo grupo são determinantes para o bom desenvolvimento do coral, todos os conteúdos trabalhados em um coro, mesmo que por vezes sejam ou pareçam individuais, tem como objetivo melhorar os aspectos coletivos como a qual idade sonora, a afinação, o timbre, sincronia entre os naipes e o ritmo dentre outros. Observando o trabalho de Costa (2005, p. 10) vemos: “A assimilação de tão variada gama de conteúdos certamente dependerá do envolvimento das mais diferentes aptidões humanas, como as capacidades cognitivas, motoras e afetivas”. Sendo assim, estimular as relações afetivas e coletivas no trabalho de canto coral pode influenciar positivamente o processo de ensino/aprendizagem.

Conforme o planejamento elaborado em aula, ficamos com a incumbência de dirigir o primeiro vocalise, tarefa que nos levou a refletir sobre como seria a abordagem mais adequada com os coralistas. Levando em consideração seu perfil optamos pelos seguintes pontos:

- Exercícios básicos de alongamento corporal;

- Explicar sobre a postura adequada ao canto e a respiração diafragmática;

- Escolher exercícios vocais de fácil realização;

- Exercícios que deveriam abranger uma tessitura que possibilitasse que todos, ou pelo menos a maioria dos coralistas fossem capazes de realizá-los.

Seguindo este guia, após as apresentações formais, iniciamos o ensaio com o trabalho na área da consciência corporal, através de alongamentos físicos e esclarecimentos sobre a postura do cantor. Estes pontos são de grande ajuda na qualidade da emissão sonora, pois predispõem o coralista para a atividade musical e condicionam a postura física necessária para cantar. Em seguida explicamos sobre o funcionamento do diafragma para iniciarem sua conscientização da musculatura utilizada para a respiração baixa e o canto, explanando sobre seu funcionamento e realizando exercícios para seu desenvolvimento. Quando o coralista toma consciência desta forma de respiração, que é inerente ao ser humano ao nascer, e que, com o passar do tempo perde-se por uma série de fatores culturais e sociais, melhora o 
controle de sua musculatura abdominal, necessária a prática do canto, e pode assim obter resultados vocais e musicais mais consistentes.

\begin{abstract}
A respiração é um elemento tão essencial para o canto quanto é para a própria vida. Ela é, nos dois casos, a fonte básica de energia para sua sustentação. É através da respiração que o cantor pode colocar suas cordas vocais para vibrar. Diversos outros parâmetros vocais, como a afinação, a ressonância e a projeção, dependem diretamente da respiração, tal é a sua importância para o canto. (COSTA, 2005, p.80)
\end{abstract}

Este ponto para a prática do canto coral exige do coralista que ele desenvolva uma nova consciência física em relação a sua maneira de respirar, adaptando-se a essa outra forma de utilizar seu aparelho respiratório. Para iniciar tal processo, ensinamos ao grupo um exercício onde inspiravam apenas expandindo o abdômen e não deixando ocorrer dilatação da caixa torácica (respiração baixa), de forma que tivessem que pensar para controlar a musculatura abdominal para assim dar início ao processo de conscientização desta forma de respiração.

Após esta explicação, falamos a eles sobre o funcionamento do exercício em Bocca Chiusa e sua execução com a respiração diafragmática. Para realizá-lo escolhi partir da seguinte região melódica ${ }^{24}$ :

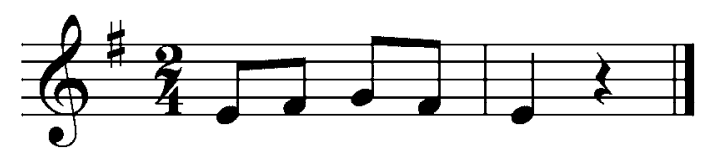

Esta escolha foi orientada pelo fato de não conhecermos as habilidades vocais dos coralistas, então ocorreu-nos a idéia de utilizar uma região intermediária para iniciar o exercício que não oferecesse maiores dificuldades em sua entoação tanto na região grave quanto para a aguda, iniciando com o Mi3 e a nota mais aguda o Dó4 ${ }^{25}$. Para sermos mais objetivos vamos definir entoação.

\footnotetext{
${ }^{24}$ Como é de costume no canto coral os homens cantam na oitava inferior.

${ }^{25}$ Ibdem 15
} 
Entonação [entoação]. Em uma apresentação musical, o termo é utilizado para descrever a precisão de tonalidade das notas individuais de um cantor ou instrumentista. (SADIE, 1994, p. 299)

Vejamos outra fonte:

Entonação [entoação]. O ato de entoar, de dar ou por no tom, do iniciar o canto. 2. Medida em que um cantor, violinista, etc. está afinado (boa entonação) ou desafinado (má entonação). (ISAACS, 1985, p. 114)

Mediante estas definições, a escolha da tessitura para o exercício citado se deu com objetivo de melhor observarmos as habilidades dos candidatos para entoarem a melodia proposta, resultado que poderia nos dar informações bastante significativas sobre suas necessidades de aprendizagem no campo da escuta melódica. Segundo a dissertação de Costa (2005, p. 9), que é um dos principais referenciais deste trabalho vemos:

O sucesso de um processo de diagnose coral dependerá amplamente da possibilidade de se realizar uma avaliação eficaz do grau de conhecimento e do nível de habilidade dos integrantes do coro em relação aos conteúdos fundamentais da área coral.

Desta forma, o resultado da execução do primeiro vocalise pelos coralistas conforme o descrito no relato do aluno regente Renato, pode sugerir a dificuldade para a imitação vocal de uma melodia, fator que pode ocorrer devido ao pouco desenvolvimento da escuta melódica, da percepção vocal ou mesmo de ambas as possibilidades. Também podemos considerar o fato de que talvez tenha sido a primeira vez que estas pessoas cantaram em Bocca Chiusa, o que pode causar insegurança para sua execução.

Para o exercício seguinte ampliamos a quantidade de notas e separamos as pessoas em dois grupos, um com homens e outro com mulheres, pra assim observar melhor as habilidades de cada grupo. Então utilizamos a seguinte seqüência melódica ainda em Bocca Chiusa: 


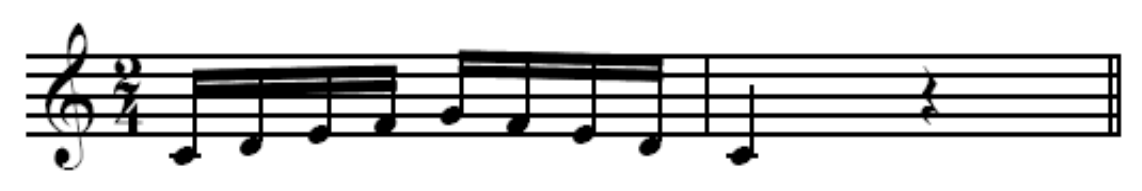

Com este procedimento já houve melhora na qualidade de afinação dos dois grupos, principalmente o masculino. Embora Renato não cite em sua avaliação, realizamos mais um exercício com a mesma melodia, mas utilizando agora o canto com vogais, que foi efetuado na seguinte ordem: $i, e, a$, o e $u$, (uma a cada execução), para assim podermos observar melhor como eles entoavam a melodia nas alturas exigidas. Este exercício revelou participantes com necessidades para desenvolvimento de suas habilidades musicais e vocais as quais citaremos mais adiante.

Os objetivos do ensaio foram bastante específicos e o trabalho foi todo direcionado para emissão vocal, que implica na vocalização de melodias utilizadas nos exercícios, onde se inicia o trabalho da escuta melódica e a emissão vocal a partir da utilização do diafragma, desenvolvendo uma nova consciência sobre a forma de usar o aparelho respiratório e fonador. Da mesma maneira a escolha da música para este ensaio aconteceu a partir do mesmo pensamento, onde procuramos direcionar a abordagem dos mesmos conteúdos desenvolvidos durante o vocalise.

Coube-nos também a responsabilidade de ensinar esta peça ao grupo. Como as pessoas ainda não liam partitura optamos por ensinar a música utilizando o procedimento de cantar pequenas frases até ensiná-la por completo. Enquanto aprendiam os trechos, não os separamos em naipes e os mantivemos cantando juntos de forma que não apresentaram maiores dificuldades, embora alguns dos coralistas não conseguissem afinar e/ou entoar corretamente. Quando separamos a peça em forma de cânone o que ficou evidenciado foi o fato das vozes que começavam depois (segundo grupo) foram sempre influenciadas pela melodia do primeiro grupo, o que os levou por diversas vezes a uma instabilidade vocal não conseguindo manter sua linha melódica simultaneamente a outra e, em alguns casos acabavam por sair de sua linha para cantarem a primeira. Os grupos foram divididos como no vocalise, homens e mulheres, e esta dificuldade continuou aparecendo, ou seja, independente de qual grupo iniciasse o cânone o segundo grupo era influenciado pela melodia do primeiro. 
Sendo assim, a partir da verificação da avaliação deste ensaio, dentro dos parâmetros definidos para a realização desta análise de procedimentos e conteúdos musicais, apontamos as seguintes necessidades de aprendizagem a serem inicialmente desenvolvidas com este coro:

- Afinação das alturas;

- Cantar intervalos melódicos ascendentes e descendentes

- Consciência física da emissão sonora

- Postura corporal geral do coro

- Memorização melódica

- Correção e qualidade na realização dos fraseados da música

- Consciência auditiva do próprio som

- Percepção das outras vozes.

- Manutenção da afinação ao longo da peça

\subsection{Avaliação de 16/04/2008}

A avaliação do ensaio foi realizada pela aluna regente Caiti Hauck da Silva que fez a seguinte descrição das atividades realizadas neste dia:

OBJETIVOS DO ENSAIO: Nossos objetivos neste ensaio foram: receber novos coralistas; explicar brevemente o mecanismo da respiração no canto; realizar exercícios de respiração; ensinar a música Canten Señores Cantores até o final e ensaiar as músicas Duas Cirandas e Baião, que foram trabalhadas no ensaio anterior.

\section{- $\quad$ Como você avalia o resultado geral do ensaio?}

O ensaio foi muito produtivo. O professor Marco Antonio iniciou o ensaio desejando boas vindas aos novos coralistas e em seguida começou o trabalho sobre respiração. Ele explicou o funcionamento do diafragma e a sua importância na respiração dos cantores, além de falar também da respiração intercostal e seu funcionamento. Depois desta explanação, o professor realizou exercícios respiratórios, nos quais o coro, executando a respiração conforme explicado, soltava o ar primeiramente em $s$ e em seguida com a vogal $i$ em uma única nota (mi). 
Seguindo, o professor Marco Antonio começou o aquecimento vocal, aproveitando a oportunidade para conhecer melhor a voz dos coralistas e já fazer uma pré-classificação vocal destes. Foram realizados os seguintes exercícios: 1) em graus conjuntos da Tonica até a quinta e voltando à Tonica (do-ré-mi-fá-sol-fá-miré-do) com a vogal $i$, primeiramente só com homens, depois só com mulheres e por fim todos juntos; 2) graus conjuntos descendentes da quinta até a Tonica (sol-fámi-ré-do) com a vogal $i$, só com homens, primeiro descendo em tonalidade (para observar a extensão vocal nos graves) e depois subindo (para observar os agudos) a partir deste exercício o professor Marco Antonio pode classificar vocalmente alguns homens; 3 ) em graus conjuntos da Tonica até a terça e voltando à Tonica (do-ré-mi-ré-do) com a vogal $i$, só com mulheres, subindo em tonalidade; 4) em graus conjuntos descendentes da terça até a Tonica e voltando à terça (mi-ré-do-rémi) com a vogal $i$, só com mulheres, descendo em tonalidade- algumas mulheres foram classificadas vocalmente depois deste exercício; 5) tríade maior com as vogais $i$ e $a$ (do-mi-sol-mi-do, i-a-a-a-i), com homens e mulheres.

Às 18:40 foi iniciado o ensaio da música Cantem Señores Cantores com o aluno-regente Paulo. Primeiramente o aluno regente Isaac passou para os coralistas a pronúncia da letra em espanhol. Em seguida, o aluno-regente Paulo relembrou com os homens a segunda voz da peça, depois ele fez o mesmo com a linha das mulheres, seguindo assim para a execução da música até o ponto aprendido no ensaio anterior. Feito isso, o aluno-regente Paulo ensinou aos coralistas a parte final da peça, que ainda não tinha sido trabalhada. O coro não apresentou dificuldades para aprender as melodias, cantando algumas vezes somente esta parte final. Em seguida o aluno-regente Paulo conduziu a música do começo ao fim.

Às 19h o aluno-regente Renato começou o ensaio da música Duas Cirandas. Depois de ter relembrado as melodias com os coralistas, o aluno-regente trabalhou o fraseado e a dinâmica da peça, explicando de forma bastante didática aos coralistas o que são esses termos musicais e como executá-los. O coro respondeu bem aos pedidos do aluno-regente.

Por fim, o aluno-regente Paulo ensaiou a música Baião - a primeira que o coro aprendeu - que foi executada com bastante entusiasmo pelos coralistas.

\section{Análise do ensaio:}

Conforme o descrito pela aluna regente Caiti, observamos que o ponto básico do ensaio é o trabalho de conscientização da respiração, que neste dia foi realizado pelo prof. Dr. Marco Antonio, que fez uma explanação clara e detalhada para os coralistas reforçando as abordagens que já haviam sido realizadas pelos monitores. O exercício respiratório que realizou juntamente com o coro agregou um elemento novo que foi a associação da respiração diafragmática proposta para o canto, onde através do exercício descrito na 
avaliação ele mostra como entoar uma nota utilizando o apoio correto combinando o gasto de ar através da consoante "s” e da emissão da vogal “i”.

Em seguida, dirigiu o vocalise direcionado para o desenvolvimento a execução de melodias simples, primeiramente uma escala até o $5^{\circ}$ grau:

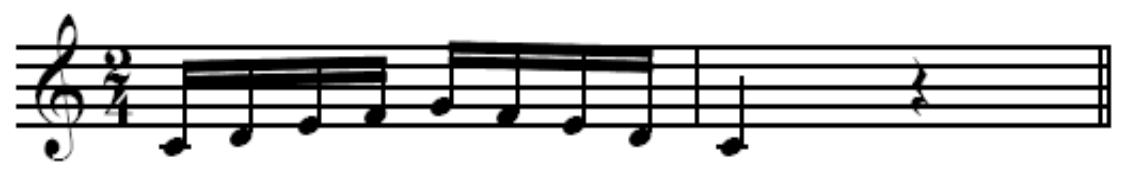

Separando os naipes pôde ouvir melhor e direcionar onde estavam os pontos a ser trabalhados verificando as habilidades no campo da afinação e da escuta melódica. A opção de fazer exercícios com os homens e as mulheres em momentos diferentes pode ajudar a construir a segurança dos coralistas, pois em uma fase iniciação em canto coral algumas pessoas tendem a cantar imitando a voz de outro coralista mais seguro, o que pode levar as mulheres a cantarem numa região mais grave e/ou homens em uma região mais aguda que não a natural, e este acontecimento pode levá-los a ter dificuldade para executarem suas vozes dentro do contexto de obras corais, além de poder causar sérios problemas vocais. A maneira como o Prof. Marco Antonio conduziu o vocalize contribuiu para que o coro tivesse melhor resultado de afinação de suas melodias nas obras ensaiadas neste dia, pois a escolha dos exercícios veio de encontro com as necessidades de aprendizagem das pessoas, abordando sistematicamente cada um deles, orientando progressivamente a execução de cada vocalise levando-os a construção consciente dos aspectos vocais e musicais trabalhados.

No caso da peça Canten Señores Cantores, que é a duas vozes e foi divida com a primeira voz para as mulheres e a segunda para os homens, utilizei o mesmo procedimento do vocalize e ensaiei um grupo por vez para relembrar o trecho que já haviam aprendido no anteriormente, e quando juntei as vozes o resultado foi superior ao da semana anterior, cada grupo estava mais seguro com sua linha melódica. Mas quando ensinei o trecho restante eles ainda apresentaram dificuldade para manter a afinação e sustentar suas vozes, pois para eles ainda é muito nova a sensação de cantar uma melodia enquanto outro grupo canta outra, e para nós era bem nítido como alguns intervalos harmônicos formados pelas duas vozes não afinavam, fato que aponta que precisamos pensar numa melhor maneira de ajudá-los a desenvolver esta habilidade. 
Na peça Duas Cirandas, como o aluno regente Renato ainda está trabalhando o aprendizado da música, os resultados de afinação são mais consistentes, pois como o coro todo canta junto as duas linhas melódicas, as questões de influência de um timbre em outro já começam a diminuir, o que mostra que o trabalho desenvolvido durante os vocalises e nas outras obras já começa a mostrar resultados positivos. O trabalho com a dinâmica do som realizado por ele foi bem sucedido, o grupo entendeu e respondeu prontamente ao comando do regente. Considero este um passo da maior importância, pois isto revela que já começam a melhorar sua percepção em relação às características do som.

A última música, Baião de Ninar, como nos relata Caiti, foi cantada com bastante entusiasmo, mas também apresentou dificuldades na afinação das melodias e dos intervalos harmônicos, além de falta de compreensão e percepção rítmica comprometendo sua execução.

A partir da verificação da avaliação deste ensaio e seus aspectos, dentro dos parâmetros definidos para a realização desta análise de procedimentos e conteúdos musicais, apontamos as seguintes necessidades de aprendizagem a serem desenvolvidas com este coro:

- Afinação das alturas;

- Cantar intervalos melódicos ascendentes e descendentes;

- Memorização melódica;

- Manutenção da afinação ao longo da peça;

- Qualidade de afinação dentro dos naipes - afinação das melodias;

- Qualidade de afinação entre os naipes - afinação das simultaneidades;

- Consciência física da emissão sonora (memória da tessitura);

- Postura corporal geral do coro;

- Consciência auditiva do próprio som;

- Consciência e compreensão melódica;

- Promover a prática do canto coral a 2 vozes e a habilidade para tanto. 


\subsection{Avaliação de $07 / 05 / 2008$}

A avaliação do ensaio foi realizada pelo aluno regente Isaac Terceros que fez a seguinte descrição das atividades realizadas:

OBJETIVOS DO ENSAIO: A realização da classificação vocal dos coralistas pelo Prof. Dr. Marco Antonio; iniciar uma explanação sobre o parâmetro de intensidade dos sons e ensaiar as peças O Anel, Baião de Ninar, Canten Señores Cantores e ensinar o cânone Cuca Burra.

- $\quad$ Os objetivos do ensaio foram atingidos?

Foram atingidos em parte. O planejamento preparado anteriormente ao ensaio teve que ser adaptado às circunstancias.

- $\quad$ Houve alguma modificação nas atividades previstas para o ensaio?

Estava planejado fazer a classificação vocal de todos os coralistas. Não foi possível completar esta atividade. Só as vozes femininas foram classificadas e o tempo foi insuficiente para classificar aos homens.

A aluna regente Caiti esteve ajudando o professor Marco Antonio e por esse motivo não trabalhou a peça $\mathrm{O}$ Anel como estava previsto no planejamento.

Um problema que ainda enfrentamos foi relacionado ao horário. As 18:00 só tínhamos 9 coralistas na sala. $\mathrm{O}$ ensaio começou com alguns minutos de atraso.

- $\quad$ Como você avalia o resultado geral do ensaio?

O ensaio funcionou e foi proveitoso porque puderam ser trabalhados assuntos importantes como a explicação e posterior trabalho prático das dinâmicas (piano, mezzo piano, mezzo forte, forte). O mestrando regente Paulo realizou uma importante explanação sobre este aspecto usando exemplos e exercícios nas próprias peças do repertorio.

O momento do aquecimento também foi importante porque foram dadas explicações sobre respiração e o resultado sonoro esta sendo mais interessante e de melhor qualidade. 
Uma nova musica começou a ser trabalhada: Cuca Burra. O mestrando regente Paulo passou a pronuncia deste cânone. Logo se ensinou a melodia. Trabalhamos primeiramente com um grupo só e depois dividindo em até três grupos (dois de mulheres e um de homens).

Posteriormente foram trabalhadas mais duas peças: Canten Señores Cantores e Baião, pelo mestrando regente Paulo.

Análise do ensaio:

Neste momento, o desenvolvimento de nossa investigação se tornou mais árduo, pois devido a uma instabilidade na freqüência dos coralistas e a chegada de novos integrantes a cada ensaio nos levou a refazer alguns passos já realizados no início do trabalho para podermos tentar um nivelamento musical entre os componentes e assim dar continuidade. Como citado na avaliação de Isaac, novamente trabalhamos as questões de intensidade do som aplicadas ao repertório, retornamos ao ponto inicial a abordagem da consciência da respiração e todos os outros já citados, dentre os quais os mais abordados foram:

- Afinação das alturas;

- Cantar intervalos melódicos ascendentes e descendentes;

- Memorização melódica;

- Manutenção da afinação ao longo da peça;

- Qualidade de afinação dentro dos naipes - afinação das melodias;

- Consciência física da emissão sonora (memória da tessitura);

- Postura corporal geral do coro;

- Consciência auditiva do próprio som;

- Consciência e compreensão melódica;

- Promover a prática do canto coral a 2 vozes e a habilidade para tanto

Como havia uma mescla entre os coralistas que acabavam de ingressar e os que estavam desde o princípio, revemos as opções de repertório e ao invés de ensinar uma obra com mais vozes decidimos utilizar outro cânone. Esta escolha foi feita devido a sua 
característica harmônica, pois no momento em que é executado com os três grupos forma acordes maiores em alguns trechos, levando-os a trabalhar melhor sua escuta das outras paralelas, a afinação das simultaneidades e a execução de sua voz no contexto sonoro. O resultado foi satisfatório, mas alguns coralistas acabaram sendo influenciados pela melodia do grupo que começava o cânone e migravam da sua voz para a outra, fato que aponta para uma audição interna frágil, e aponta para a necessidade de desenvolver a habilidade de cantar sua linha melódica sem ser influenciados por outra ou outras.

Mantivemos no repertório as peças Baião de Ninar e Cantem Señores Cantores para aproveitarmos a segurança dos cantores que estavam no grupo há mais tempo para servir de referência vocal aos novos e assim dinamizar seu processo de aprendizagem, principalmente no campo da escuta melódica, na entoação das melodias e no desenvolvimento da percepção de sua voz no contexto. O coro se portou bem, cantando ambas as peças com bastante desenvoltura, mas revelando ainda importantes necessidades de aprendizagem dentro dos parâmetros definidos para a realização desta análise de procedimentos e conteúdos musicais. Apontamos os seguintes conteúdos que necessitam continuar a ser desenvolvidos com este coro:

- Afinação das alturas;

- Cantar intervalos melódicos ascendentes e descendentes;

- Memorização melódica;

- Manutenção da afinação ao longo da peça;

- Qualidade de afinação dentro dos naipes - afinação das melodias;

- Qualidade de afinação entre os naipes - afinação das simultaneidades;

- Consciência física da emissão sonora (memória da tessitura);

- Consciência auditiva do próprio som;

- Consciência de sua nota na harmonia;

- Consciência e compreensão melódica;

- Percepção das outras vozes. 


\subsection{Avaliação de $28 / 05 / 2008$}

A avaliação do ensaio foi realizada pelo aluno regente Márcio Ocon que fez a seguinte descrição das atividades realizadas neste dia:

OBJETIVOS PRINCIPAIS: Intensificar o trabalho de técnica vocal e continuar o desenvolvimento das peças O Anel, Cuca Burra, Canten Señores Cantores,Duas Cirandas e Minno Amor.

O nosso ensaio começou com alguns minutos de atraso devido à ausência de vários integrantes do coro, fato que já era esperado em função do congresso realizado pela Universidade e por não haver aula durante a semana toda. Contudo, após alguns minutos de espera iniciamos nossas atividades com as mesmas pessoas que estavam presentes no horário, fato que este, que seria prudente que não se repetisse, pois, o tempo de ensaio é bem curto, e também porque tanto para quem chega no horário ou depois dele isso seria uma forma de estimular esse aspecto da disciplina do grupo.

A aluna regente Caiti realizou a preparação vocal pela terceira vez consecutiva. Acredito que ela está fazendo um bom trabalho e vem crescendo constantemente, o grupo recebe com muita confiança e se esforça para seguir suas orientações.

No ensaio a aluna regente Caiti conseguiu um resultado muito positivo com a peça $O$ Anel. O coro está seguro para cantá-la e a afinação melhorou muito de forma geral.

O mestrando regente Paulo deu prosseguimento ao ensaio com o cânon Cuca Burra, que no ensaio anterior havia apresentado algumas dificuldades que não puderam ser trabalhadas pela falta de tempo. Desta vez a tranqüilidade do ensaio possibilitou um trabalho mais consistente e abordando questões como a afinação, o andamento, o fraseado, enfim, a musicalidade ficou em primeiro plano. Na etapa seguinte, o mestrando regente Paulo conseguiu com a peça Cantem Senhores Cantores o mesmo que havia conseguido com o cânon Cuca Burra, só que de forma muito mais rápida, o quê demonstra uma acertada escolha em suas opções pedagógicas. De fato o que pudemos observar foi um processo de transposição de conhecimento, que partindo de uma peça "fácil" onde se gastou um tempo relativamente grande obteve-se um resultado muito mais rápido e direto em outra obra com dificuldades aparentemente muito maiores.

A peça Duas Cirandas foi trabalhada pelo aluno regente Renato. Sua atuação é sempre muito consistente e a obra está "pedindo palco”. A última coisa 
que faltava foi conseguida neste ensaio através de uma atividade simples, porém muito eficiente, assim como são as boas idéias. A atividade que tinha o objetivo de trazer o espírito que o texto exigia consistia em cantar movimentando-se pela sala como se todos estivessem numa festa de carnaval. A partir da compreensão dessa "imagem musical” o coro mostrou um salto na qualidade interpretativa.

A seguir realizamos um breve ensaio de naipe com a peça Miño Amor.

A peça Minno Amor, regida pela aluna regente Caiti, vem colocando um desafio muito grande em termos de afinação e neste dia pode-se observar um momento muito forte com essa obra. Durante o ensaio o naipe de contralto apresentou problemas que desestruturavam o conjunto, então o Professor Marco realizou ajuste na técnica vocal orientando o naipe a canta mais piano e com um timbre mais homogêneo. A aluna regente Caiti deu prosseguimento ao seu ensaio com essa obra de forma muito tranqüila.

Tivemos um dos melhores ensaios do Coro Oficina neste dia.

Análise do ensaio:

A avaliação do aluno regente Márcio descreve um momento muito importante do Coral Oficina Comunicantus, pois é quando começam a aparecer os resultados de forma mais consistente no caminho do desenvolvimento de sua escuta melódica. Após falar sobre as faltas de alguns coralistas ele começa sua avaliação de ensaio referindo-se ao trabalho da aluna regente Caiti Hauck, já citada neste trabalho, que estava realizando os exercícios de vocalize com o coro pela terceira vez seguida, ela utilizou neste período exercícios que abordavam aspectos parecidos como postura adequada ao canto, respiração diafragmática, apoio e afinação. Esta seqüência possibilitou aos coralistas desenvolver maior segurança para cantar as peças, pois começavam ter mais consciência dos aspectos físicos, auditivos e vocais necessários ao canto coral.

Em seguida iniciamos o ensaio da peça Cuca Burra, Márcio cita que os coralistas apresentaram algumas necessidades durante o ensaio anterior, desta forma planejei uma atividade para ajudá-los. Teresa Mauri, educadora que participou da reforma do ensino na Espanha, afirma que uma das tarefas do educador é: 
Proporcionar outras situações úteis para os alunos, a fim de que possam diversificar o uso do procedimento e possibilitem uma prática generalizada e constante. Estas situações devem oferecer aos alunos a oportunidade de executar de forma voluntária, consciente e inovadora o procedimento, bem como de revisar a execução e realizar seu aperfeiçoamento. (MAURI, 2003, p. 116)

Mauri continua:

Os professores ajudarão os alunos a estabelecer semelhanças entre a nova tarefa de aprendizagem e outras atividades anteriores (...), a elaborar analogias que relacionem esta experiência com outras que estão no repertório dos alunos (...) e a situar a atividade de aprendizagem em relação a outras já realizadas anteriormente (...). (MAURI, 2003, p. 107)

Observando o vocalise percebi como o grupo havia conseguido uma boa qualidade de afinação, aproveitei que estavam motivados e realizei uma atividade ${ }^{26}$ vocal usando inicialmente as notas e depois o ritmo que compõem a melodia da peça, de forma que não relacionassem inicialmente que estavam cantando os mesmos intervalos que anteriormente apresentavam dificuldade para entoar. Planejei o exercício de modo que o seu desenvolvimento levasse os coralistas a naturalmente perceberem que era a música que não conseguiam cantar corretamente, ou seja, a atividade proporcionou que eles próprios construíssem suas analogias, relacionando a experiência com as notas à melodia do cânone, mas, agora, já conseguiam cantar com facilidade e desenvoltura, trazendo uma afinação mais precisa do que a que havia sido atingida no ensaio anterior. Este fato os deixou bastante satisfeitos, então aproveitei e estabeleci relações pertinentes à próxima peça (Cantem Señores Cantores), e o resultado de afinação das vozes veio bem depressa, devido ao fato de terem percebido como deveriam trabalhar os aspectos físicos, vocais e auditivos, tendo como conseqüência a afinação das respectivas melodias de forma bem mais afinadas.

Da mesma maneira agiu o aluno regente Renato com a peça Duas Cirandas, quando utilizou a imagem da dança em um baile de carnaval para contextualizar e relacionar o estilo mais apropriado para cantar, a partir da elaboração de analogias entre as duas situações e a utilização desta experiência em benefício da realização musical.

Já no trabalho da peça Minno Amor, com a aluna regente Caiti, por se tratar de uma obra a três vozes, estrutura e encadeamentos melódicos mais complexos, o coro apresentou

\footnotetext{
${ }^{26}$ A atividade está descrita no capitulo 4.
} 
necessidade de desenvolver melhor sua percepção auditiva para a compreensão melódica, maior domínio físico para obter melhor controle da técnica vocal. A linha de baixo (terceira voz) com vários saltos de quinta justa e a do contralto (segunda linha) com presença de sensíveis, exigem bastante controle técnico para sua correta entoação.

Neste ensaio foram trabalhados os seguintes aspectos freqüenciais:

- Afinação das alturas;

- Manutenção da afinação ao longo da peça;

- Qualidade de afinação dentro dos naipes - afinação das melodias;

- Qualidade de afinação entre os naipes - afinação das simultaneidades;

- Consciência auditiva do próprio som;

- Percepção das outras vozes;

- Promover a prática do canto coral a 2 vozes e a habilidade para tanto.

A partir da verificação da avaliação deste ensaio e seus aspectos, dentro dos parâmetros definidos para a realização desta análise de procedimentos e conteúdos musicais, apontamos os seguintes conteúdos devem continuar sendo desenvolvidos com este coro:

- Afinação das alturas;

- Cantar intervalos melódicos ascendentes e descendentes;

- Memorização melódica;

- Manutenção da afinação ao longo da peça;

- Qualidade de afinação entre os naipes - afinação das simultaneidades;

- Consciência física da emissão sonora (memória da tessitura);

- Consciência auditiva do próprio som;

- Consciência e compreensão melódica;

- Promover a prática do canto coral a 2,3 e 4 vozes e a habilidade para tanto. 


\subsection{Avaliação de 11/06/2008}

Novamente manteremos algumas perguntas que compõem a ficha de avaliação de ensaio dos coros do Comunicantus: Laboratório Coral para maior clareza do contexto do ensaio. Esta avaliação foi elaborada pelo aluno regente Renato Martins de Oliveira Spinosa, que faz a seguinte descrição das atividades realizadas neste dia:

OBJETIVOS DO ENSAIO: Início do aprendizado da peça Tres Morillas m'enamoran e o ensaio da peça Minno Amor.

- $\quad$ Os objetivos do ensaio foram atingidos?

Em boa parte sim. Pelo fato do coro ainda ser um grupo em formação, com cantores pouco experientes e haver um agravante, que é o da rotatividade destes entre um ensaio e outro, fica difícil prever um rendimento. No entanto, as tarefas planejadas para o ensaio foram cumpridas, com mais ou menos sucesso.

- $\quad$ Como você avalia o resultado geral do ensaio?

Bom. Apesar de ainda sentirem bastante dificuldade, os coralistas aos poucos demonstram uma evolução no que diz respeito à consciência das vozes como um coletivo, e da necessidade de harmonia entre elas neste contexto; o que em minha opinião é muito mais importante do que necessariamente executar com sucesso as músicas do repertório proposto.

O aquecimento começou pontualmente às 18 horas e nele foram realizados cinco vocalizes.

O primeiro com a extensão de uma $2^{\mathrm{a}}$ maior com as vogais “i-e-a-o-u”, sendo uma vogal para duas notas.

O segundo vocalise, com extensão de uma quinta e também com a mesma ordem das vogais, com movimento ascendente e descendente de terças maiores.

O terceiro, com "pra-ia-ia-ia-iá” que passa pelo primeiro terceiro e quinto graus.

O quarto vocalise, com "io-ri-do", onde foi enfatizado que o salto de quinta deveria ser preparado para que a nota não fosse emitida com afinação baixa. Neste mesmo 
exercício pediu-se atenção para que os coralistas mantivessem o apoio na descida de graus descendentes.

As vozes agudas atingiram o fá natural no seu ápice agudo, enquanto as vozes graves desceram até lá natural (contralto) e sol natural (baixo).

O último vocalise foi o da sexta acrescentada, onde usou-se como letra a palavra "vivo".

O aquecimento foi terminado às 18:25, quando o coro foi separado em naipes.

A letra foi ensinada e repetida pelas cantoras, e logo depois a aluna-regente Caiti cantou a nova música (Três Morillas) separando por frases que eram repetidas. A média de repetição era 3 a 4 vezes para cada frase até que as cantoras as memorizassem.

Houve insegurança em relação a sincopa da segunda frase e a diferença entre a primeira e a terceira melodia.

Depois de tiradas as dúvidas, a música foi cantada duas vezes sem interrupções e com sucesso.

Passou-se ainda a música Mino Amor, quando contraltos tiveram certa dificuldade em cantar junto com sopranos. Foi quando a aluna-regente Caiti passou separadamente as vozes e eu optei por não cantar com contraltos, para que não confundissem suas linhas melódicas.

Observei um fato interessante que considero importante que seja comentado. Esse foi o primeiro ensaio cujos naipes femininos foram acompanhados pelo violão e não pelo teclado. Isso exigiu com que as cantoras diminuíssem o volume para que pudessem escutar o violão. $\mathrm{O}$ naipe de contraltos durante o ensaio anterior teve atenção especial do professor Marco Antonio pelo excesso de volume, e esse problema foi resolvido naturalmente com o ensaio com violão. O que me fez concluir mais uma vez que o acompanhamento (para fins didáticos como esse) também é uma referência importante para os cantores e não só a voz dos monitores.

Os naipes se reencontram no ensaio geral e é passada a música Tres Morillas com todas as vozes pela primeira vez sem muito sucesso. Os cantores estranharam a primeira escuta (pouco) harmônica, mas aos pouco se acostumaram.

O aluno-regente Márcio ensinou a segunda letra para os naipes femininos e passou novamente com todas as vozes e depois revezando combinações de vozes no intuito de acostumar os cantores à harmonia.

Às 19:08 começou o ensaio de Mino Amor com todas as vozes. Na primeira passagem da música contraltos voltaram a perder sua linha enquanto homens tiveram dificuldades com a afinação e sopranos foram muito bem.

Ao passar novamente só com naipes femininos, obteve-se um resultado muito bom, e o mesmo aconteceu quando passou se sopranos e homens. 
A aluna-regente Caiti explicou como funcionariam as dinâmicas piano nas frases que repetem, mas acabou não obtendo sucesso, no entanto a afinação teve bastante sucesso, terminando assim o ensaio.

Análise do Ensaio:

Os exercícios de vocalise trabalhados foram:

1)

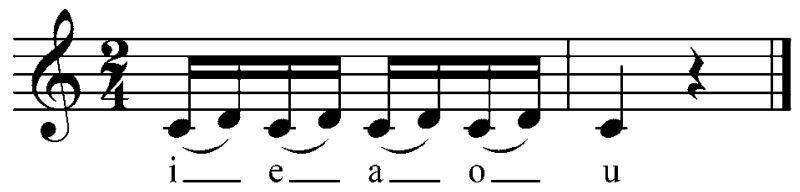

2)

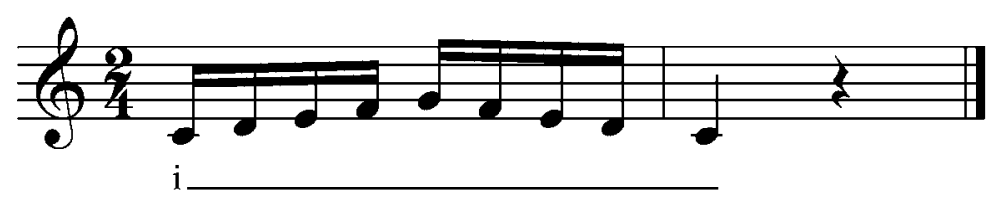

3)

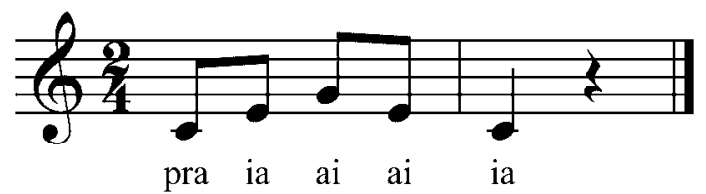




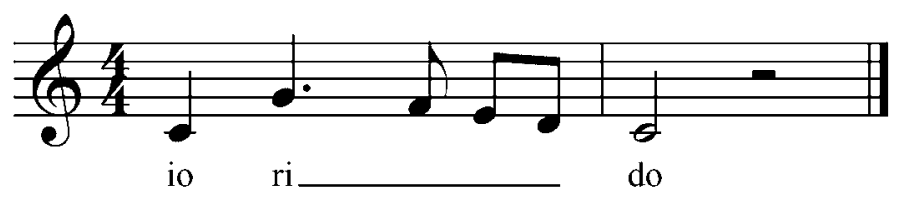

5)

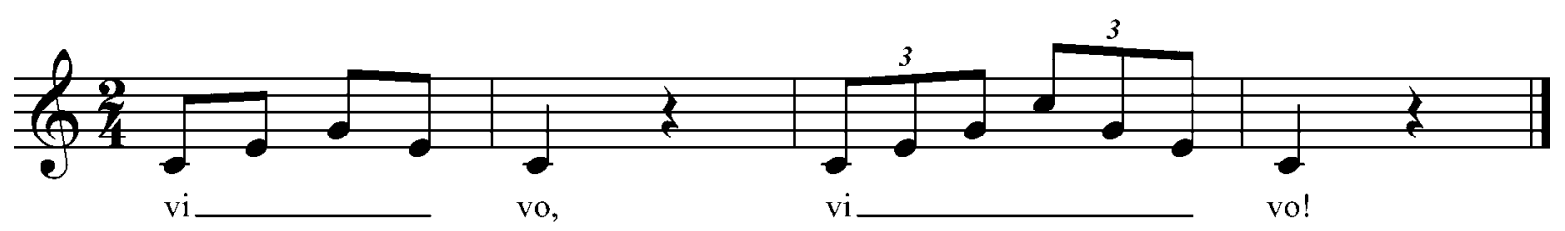

Os cinco exercícios foram escolhidos para preparar o grupo para aspectos das obras que seriam ensaiadas. Dentre os diversos pontos podemos observar três principais que são os saltos ascendentes de quinta justa (ex. 4), execução de frases melódicas descendentes (ex. 2, 3, 4 e5) e afinação de notas repetidas (ex. 1), necessidades de aprendizagem apresentadas pelo grupo desde o principio dos ensaios. Uma boa evolução foi a melhoria da qualidade de entoação em regiões de extensão vocal mais extremas, onde pudemos observar as vozes agudas atingirem o Fá natural (Fá4 e Fá3 para sopranos e tenores respectivamente) no seu ápice agudo, enquanto as vozes graves cantaram até Lá natural (Lá2 para o contralto) e o Sol natural(Sol1 para o baixo).

Neste dia iniciamos o trabalho da peça Tres morillas m'enamoram, que a aluna regente Caiti primeiramente ensinou a pronúncia do texto, que foi escrito em idioma espanhol arcaico. Segundo Schafer (1986, p. 302) "Vivemos numa época interdisciplinar e freqüentemente ocorre que uma aula de música recaia em outro assunto”, fato que é bastante comum na área do canto coral. Ainda: “Às vezes, pode-se adaptar com sucesso um modelo de uma outra área” (SCHAFER, 1986, p. 302). De fato, Caiti aproveitou a área de ensino de outra língua para facilitar a aprendizagem de conteúdos musicais. Ela primeiramente leu a tradução e abordou as diferenças de pronúncia. Depois, à medida que ela pronunciava as palavras os coralistas aprendiam. A seguir, ela trabalhou repetindo trechos que formavam 
frases da obra, orientando-os na compreensão das frases melódicas e das primeiras necessidades de aprendizagem que já surgiam naquele momento, dentre elas cito melhor uma compreensão para executar os elementos rítmicos. Assim podemos observar que a forma como Caiti ensinou o texto, com a pronúncia no mesmo ritmo em que está disposto na música, funcionou como um artifício que além de ajudar as questões relativas ao ritmo, pronúncia e a articulação do texto, também preparou os cantores para obterem melhor compreensão do conteúdo melódico. Como vemos em Mauri (2003, p. 112), os procedimentos de ensino devem permitir: "Elaborar, ligar, situar e reter os novos conhecimentos em estruturas de representação e atividade mais ou menos amplas”. De fato ao abordar primeiro as questões relativas à compreensão da execução do texto no ritmo da obra para depois ensinar os aspectos sonoros, ela possibilitou que a aprendizagem das vozes fosse ligada ao conteúdo já aprendido, facilitando a sua associação e apreensão na hora de unirem texto, ritmo e melodia.

Pudemos observar que embora todos os naipes tenham obtido bons resultados em seus ensaios, principalmente pelo fato dos exercícios de vocalise terem preparado o coro para os desafios musicais oferecidos pelas peças ensaiadas naquele momento, novamente nos deparamos com a questão da influência que a execução das três vozes causava em cada naipe. Para essas pessoas, ouvir outras vozes enquanto cantam sem que sejam induzidos a migrar para outra, ainda é um desafio a ser vencido. É necessário criar atividades que possam desenvolver esta habilidade com eles. Notamos que, ao cantarem suas linhas separadamente, existe qualidade na execução, mas, a partir da junção de todas as vozes, os coralistas sentemse inseguros e não conseguem sustentar corretamente suas linhas melódicas.

O mesmo ocorreu no ensaio da peça Minno Amor, principalmente com os homens e o naipe de contraltos, pois mesmo sendo uma música conhecida há mais tempo pelo coro, foi necessário ensaiar separadamente as vozes pra obter um melhor resultado sonoro, o que pode ocorrer pela necessidade de desenvolvimento da escuta e da consciência melódica.

Neste ensaio foram trabalhados os seguintes aspectos freqüenciais:

- Afinação das alturas;

- Cantar intervalos melódicos ascendentes e descendentes;

- Memorização melódica;

- Manutenção da afinação ao longo da peça; 
- Qualidade de afinação dentro dos naipes - afinação das melodias;

- Qualidade de afinação entre os naipes - afinação das simultaneidades;

- Consciência e compreensão melódica;

- Promover a prática do canto coral a 3 vozes e a habilidade para tanto.

Pelo que pudemos observar vários deles ainda necessitavam maior atenção. A partir da verificação da avaliação desse ensaio e seus aspectos, dentro dos parâmetros definidos para a realização de nossa análise dos procedimentos mais adequados a aprendizagem dos conteúdos musicais, apontamos os seguintes pontos que vimos como os mais necessários a serem desenvolvidos com este coro naquele momento:

- Afinação das alturas;

- Manutenção da afinação ao longo da peça;

- Qualidade de afinação entre os naipes - afinação das simultaneidades;

- Consciência auditiva do próprio som;

- Consciência e compreensão melódica;

- Qualidade de afinação dentro dos naipes - afinação das melodias;

- Consciência auditiva do próprio som;

- Percepção das outras vozes.

Esta era uma das últimas avaliações do primeiro semestre. Os conteúdos supracitados teriam continuidade de trabalho após as férias de julho.

$2^{\circ}$ Semestre de 2008

Conforme dissemos no sub-item que fala sobre a escolha do repertório do segundo semestre de 2008, integrado ao capitulo I - Escolha do repertório e tipologia dos conteúdos de 
ensino/aprendizagem trabalhados com os coralistas. A volta dos ensaios no segundo semestre foi marcada por mudanças no grupo de coralistas, que devido à modificação das disciplinas e seus respectivos horários no segundo semestre na USP, vários integrantes deixaram o coro e novos passaram a integrá-lo. Este fator foi determinante para a seqüência do trabalho, pois além da diminuição do efetivo de seus membros foi necessário retomar aspectos já trabalhados, o que resultou em um novo momento de revisão das atividades e do repertório a ser trabalhado. Neste contexto, decidimos por analisar as avaliações dos ensaios a seguir.

3.6. Avaliação de 20/08/2008

A avaliação do ensaio foi realizada pelo aluno regente Márcio Ocon que fez a seguinte descrição das atividades realizadas neste dia:

OBJETIVOS DO ENSAIO: Enfoque no trabalho de técnica vocal; retomada das peças Duas Cirandas e Minno Amor, continuar o aprendizado da peça El ciodo Del ferro Vecchio.

Foi um bom ensaio. Começamos as atividades no horário com as pessoas que estavam presentes, com o intuito de reafirmação da pontualidade como elemento importante para o funcionamento do processo.

A preparação vocal foi realizada pelo aluno regente Márcio e o aluno regente Renato ao teclado durante os vocalize. Iniciamos com um breve trabalho de relaxamento com exercícios de alongamento e respiração e seguimos posteriormente para o vocalizes.

Utilizando o exercício abaixo, realizamos um trabalho com as sílabas vibrantes "bru" e "tru" e bocca chiusa.

Exemplo 1

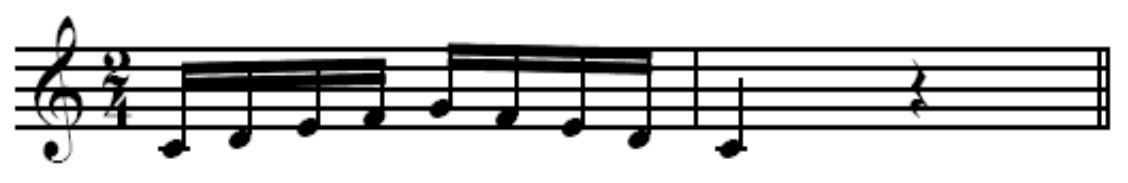


O exercício proposto em seguida, que constitui de duas partes, uma descendente e outra com um movimento que parte do grave em direção ao agudo e retorna ao grave, apresentou dificuldades na sua realização e optou-se por realizar apenas a segunda parte.

Exemplo 2

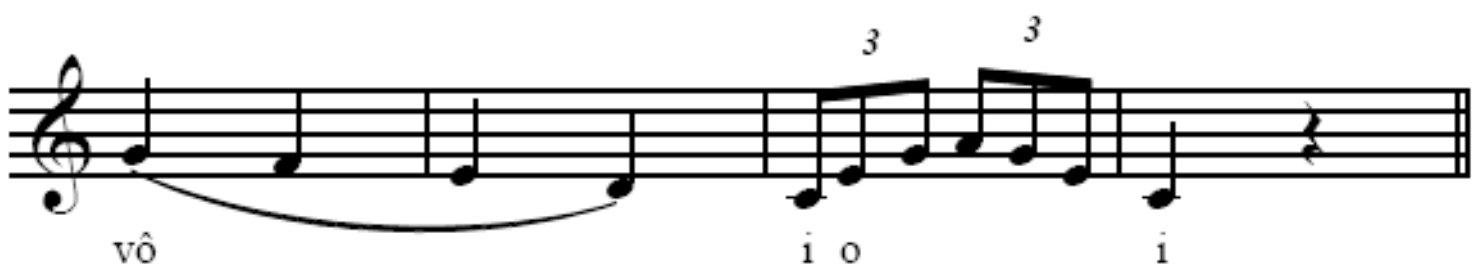

Para finalizar, realizamos o seguinte exercício:

Exemplo 3

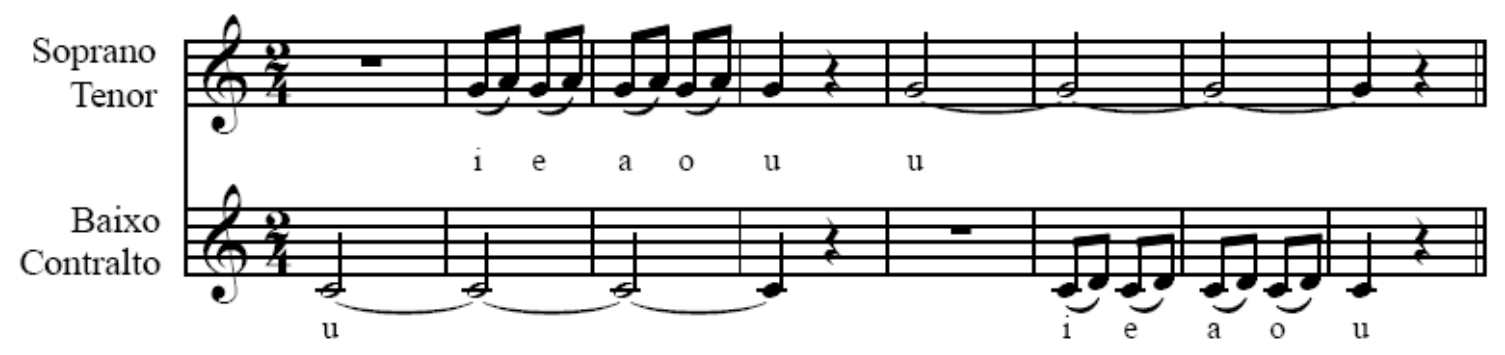

Este exercício exigiu muita concentração por parte do grupo na manutenção da afinação e teve um impacto bastante positivo.

Em seguida a preparação vocal, começamos o ensaio com a música Duas Cirandas com o aluno regente Renato, e também com o aluno regente Anselmo e o mestrando regente Paulo na realização do acompanhamento, teclado e violão respectivamente. O coro está um pouco "duro" quando canta esta música, e assim não consegue entrar dentro do espírito que a obra necessita, porém, o grupo se diverte muito com a obra, e vale a pena lembrar que a alguns ensaios atrás o aluno regente Renato propôs que o coro cantasse a música movimentando-se pela sala e 
imaginando-se dentro de um baile de carnaval, e essa atividade acrescentou muito em musicalidade durante a execução posterior. O aluno regente Renato chamou a atenção do grupo em relação a segunda voz, que deveria estar em segundo plano na dinâmica, e sendo esta cantada em piano a voz principal ficaria mais evidente sem que o grupo que a estivesse cantando precisa-se fazê-lo muito forte. $\mathrm{O}$ aluno regente Renato teve toda razão ao realizar esta observação, pois, grande parte do equilíbrio e da afinação estará resolvida quando o coro conseguir realizar a dinâmica necessária.

A música Minno Amor foi ensaiada logo em seguida com a aluna regente Caiti. O grupo estava um pouco desequilibrado para a realização da obra pelo fato de estarem presentes apenas duas sopranos, mas ao final uma coralista do naipe de contralto foi cantar com os sopranos e o grupo ficou mais equilibrado. Cabe mencionar que esta coralista foi autorizada a mudar de naipe pelo professor Marco Antônio, pois na classificação vocal era realmente um soprano, mas que no inicio da formação do grupo não tinha a técnica necessária para cantar no naipe do seu respectivo perfil vocal.

A aluna regente Caiti ensaiou a obra pela primeiras vez após o período de férias, a para isso foi muito importante retomar a memorização da música fazendo os naipes cantarem suas partes em separado antes de um execução com as três vozes simultaneamente. A obra representa um grande desafio para o grupo e esse período de férias puxou boa parte do resultado que havíamos conseguido no semestre passado, o que é bastante normal em virtude da inexperiência do grupo.

Finalizamos nosso ensaio com o cânone El Ciodo regido pelo aluno regente Isaac. Foi seu segundo ensaio com esta peça que no geral conseguiu um resultado bastante positivo. O professor Marco fez algumas observações acerca de sua postura e do gestual de sua regência que foram imediatamente aplicadas.

Análise do Ensaio:

Neste ensaio, embora com um grupo reduzido de coralistas, o aluno regente Márcio Ocon trabalhou durante o vocalise o desenvolvimento da escuta melódica de forma bastante consistente. Depois de quatro exercícios de aquecimento e afinação com intervalos descendentes (dificuldade demonstrada pelo grupo desde o semestre anterior), Márcio trouxe um outro para trabalhar a habilidade de entoar notas longas simultaneamente com movimentos melódicos (ex. 3 do relatório supracitado). Mesmo sendo apenas a repetição de um intervalo de segunda maior, a atividade criou a oportunidade dos grupos se ouvirem simultaneamente. Este procedimento propiciou aos coralistas começarem uma nova 
consciência de percepção auditiva das linhas melódicas, modificando a relação com a execução de vozes simultâneas. Não quer dizer que todos os problemas melódicos foram solucionados a partir de então, mas a tomada de consciência auditiva é que caracterizou o mérito desta atividade, ou seja, neste momento o grupo “ligou os ouvidos”.

Quando iniciou o ensaio propriamente dito, o que pudemos observar foi um grupo ainda em início de trabalho, apresentando necessidades de aprendizagem semelhantes as já trabalhadas pelos alunos regentes no primeiro semestre, sobretudo nas duas peças já trabalhadas anteriormente: foi necessário ensiná-las novamente. No planejamento de semestre a equipe tinha escolhido a peça Tourdion, canção francesa renascentista a quatro vozes mistas para dar seguimento ao trabalho, mas, pelas questões de reformulação do coro e suas necessidades de aprendizagem, foi necessário colocar outro cânone para retomar a preparação dos coralistas. A peça escolhida foi El Ciodo Del ferro Vecchio, onde foi obtido um bom resultado.

Neste ensaio foram trabalhados os seguintes aspectos freqüenciais:

- Afinação das alturas;

- Cantar intervalos melódicos ascendentes e descendentes;

- Memorização melódica;

- Manutenção da afinação ao longo da peça;

- Qualidade de afinação dentro dos naipes - afinação das melodias;

- Qualidade de afinação entre os naipes - afinação das simultaneidades;

- Consciência auditiva do próprio som;

- Consciência e compreensão melódica;

- Percepção das outras vozes;

- Promover a prática do canto coral a 2 e 3 vozes e a habilidade para tanto;

- Recuperar conteúdos e habilidades trabalhadas no semestre anterior.

Sugiro que mesmo com o resultado conseguido com a abordagem neste ensaio que continuemos trabalhando insistentemente os seguintes pontos: 
- Afinação das alturas;

- Cantar intervalos melódicos descendentes;

- Manutenção da afinação ao longo da peça;

- Qualidade de afinação dentro dos naipes - afinação das melodias;

- Consciência auditiva do próprio som;

- Consciência e compreensão melódica;

- Percepção das outras vozes;

- Promover a prática do canto coral a 2,3 e 4 vozes e a habilidade para tanto.

\subsection{Avaliação de 03/09/2008}

Esta avaliação foi elaborada pelo aluno regente Renato Martins de Oliveira Spinosa que faz a seguinte descrição das atividades realizadas neste dia:

OBJETIVOS DO ENSAIO: Ensaiar as peças escolhidas para a apresentação de 24 de setembro na Semana de Arte e Educação da ECA-USP.

- Os objetivos do ensaio foram atingidos?

Não. Tinha-se como objetivo principal adiantar o andamento das musicas preparadas no primeiro semestre, visando a apresentação do dia 24. Como algumas atividades foram canceladas, $O$ Anel foi a única música feita neste ensaio que ainda não havia sido ensaiada no semestre atual.

- Houve alguma modificação nas atividades previstas para o ensaio?

Sim. As filipetas foram distribuídas durante esta semana, e como conseqüência disso, quatro novos cantores apareceram para o ensaio. Isso fez com que o planejamento fosse alterado em prol destes novos cantores, uma vez que os monitores passaram a contar com a presença deles nos ensaios futuros. Para tanto, optou-se por não recordar algumas músicas do primeiro semestre para que se tivesse mais tempo para ensinar músicas mais simples para estes. 
- Como você avalia o resultado geral do ensaio?

Apesar de alterado o planejamento, o ensaio foi bastante bom.

Uma vez que os monitores já haviam ensinado as músicas ao longo do primeiro semestre para os outros cantores, notou-se uma melhor desenvoltura na hora de ensinar as mesmas músicas para os novos cantores. Vale lembrar que os monitores também contaram com a ajuda dos cantores antigos, que já estavam seguros para cantarem junto.

O aquecimento começou com 10 minutos de atraso, que foram dedicados às boas vindas e explicações sobre o projeto, dadas aos cantores novos.

Às 18:10 a aluna regente Caiti começou o ensaio fazendo alongamentos com o grupo e explicações sobre respiração para o canto. O primeiro exercício feito foi de respiração; soltando todo o ar, respirando em 2 tempos, retendo o ar em 2 tempos e soltando em 4 tempos (depois 6, 8, 10 e 12).

O segundo exercício, ainda de respiração, tinha enfoque nos stacattos. Se baseava em 4 tempos de 's' contínuo seguidos de 4 ataques stacattos também de 's' (um por tempo).

O terceiro já era cantando. A melodia abaixo foi cantada com vibração ( $\mathrm{Br}$ ou Tr), e em bocca chiusa, começando com vozes graves, modulando até região médio-aguda com vozes agudas e voltando ao tom inicial com quem tivesse a tessitura.

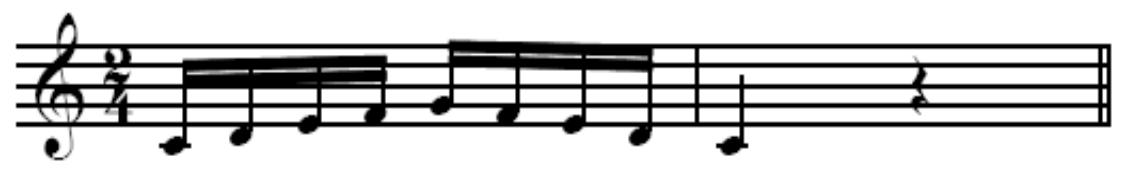

O quarto exercício tinha a melodia similar à do exercício anterior, porém com a extensão apenas de uma terça maior. Desta vez o vocalize era cantado com as vogais 'i', 'e', 'a', 'o' e 'u', sendo uma vogal para cada repetição da melodia.

Feitos esses exercícios, às 18:25 o aluno-regente Márcio fez o seguinte exercício, com o intuito de preparar os cantores para a música que seria ensaiada em seguida (O Anel), que é a 2 vozes: 


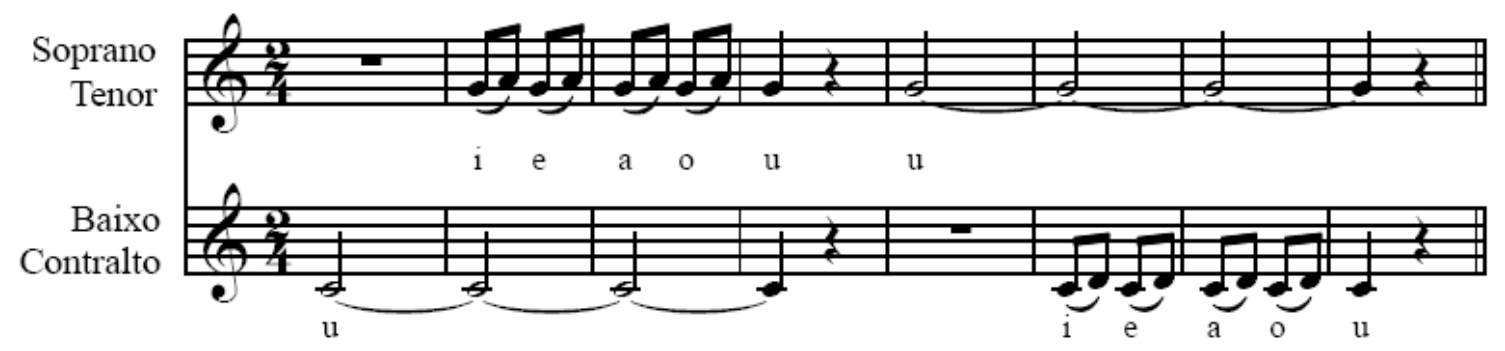

A aluna-regente Caiti volta à frente do coro para ensaiar a música $O$ Anel; ensaio que foi precedido de explicações básicas sobre como seguir uma partitura, já feita no semestre anterior.

Para ensinar a música aos cantores novos, não se teve muita dificuldade, já que os cantores antigos já conheciam suas linhas, fato que se repetiu em todas as músicas feitas nesse ensaio. Cada melodia só precisou ser repetida uma vez até que os cantores novos cantassem também. A música foi aprendida com sucesso pelos cantores novos.

Às 18:42 começou o ensaio da segunda música que foi El Ciodo Del Ferro Vecio, já ensaiada nesse semestre e que foi conduzida pelo aluno-regente Isaac. Apesar de alguns obstáculos durante o aprendizado da pronúncia, os cantores se saíram bastante bem com a melodia. Tiveram também um pouco de estranhamento no primeiro contato com o 'formato' cânone, mas uma vez compreendido o funcionamento, não tiveram dificuldades para cantar a duas vozes. Vale lembrar que os cantores antigos que estavam no ensaio também demonstraram facilidade e melhoria na afinação durante todo o ensaio.

Às 18:50 o mestrando regente Paulo conduziu o ensaio da música Baião, que por também ser um cânone, foi assimilado rapidamente pelos cantores novos. A harmonia da música por ser próxima a harmonias de conhecimento popular contribuiu para que a afinação ficasse mais exata. Este cânone foi repetido algumas vezes, variando a quantidade de repetições das vozes.

Por fim, às 19:00 começou o ensaio da última música do dia, Duas Cirandas, quando eu fui à frente do coro. O aprendizado das duas melodias foi feito com o mesmo método. Convidei os cantores antigos a cantarem duas vezes seguidas a mesma linha melódica, acompanhada por violão e piano, encerrando no final, para que se tivesse noção da forma da música. O mesmo foi feito com a segunda linha, e, uma vez apresentadas cada uma, os cantores novos foram convidados a também cantar. Feito isso, dividi o coro entre mulheres e homens (como já era feito), e cada naipe cantou uma das melodias, trocando na repetição. A forma escolhida excepcionalmente para este ensaio foi de apenas uma repetição. Mais uma vez, o enfoque no ensaio desta música foi na musicalidade, fazendo alusões a 'personagens' diferentes para cada uma das linhas. A referência dos 'personagens' continua sendo feita por demonstrar resultados consideráveis no entendimento musical dos cantores. 
Às 19:11 o ensaio foi finalizado para que se fizesse avisos sobre a Semana da Pátria, cujo ensaio não será feito, e também, sobre a mudança de local do próximo ensaio (17/09), que será realizado no Departamento de Música.

Análise do Ensaio:

Como vemos no relato do aluno regente, o objetivo central deste ensaio era o trabalho com as obras que foram escolhidas para uma apresentação, mas devido ao surgimento de novos coralistas isto precisou ser alterado. Este fato não prejudicou o resultado final do ensaio, pois a mudança de abordagem das peças neste dia não colaborou somente para os novos aprenderem as musicas, mas também funcionou com revisão para os demais, o que levou a uma qualidade de massa sonora do grupo bem interessante, fato que deixou a todos satisfeitos.

Começando nossas considerações pelo aquecimento vocal, a explanação da aluna regente Caiti foi direcionada para os novos, e os aspectos básicos da respiração da maneira como ela abordou ajudou também aos outros coralistas a reverem pontos que ainda não estavam bem fixados. Todos os exercícios de respiração foram direcionados para a utilização consciente do diafragma voltada para o canto. Seguindo com os exercícios, ela escolheu um que trabalhava a vibração, a afinação e o relaxamento da musculatura maxilar, buscando melhorar a emissão sonora.

O quarto exercício composto com a seguinte melodia:

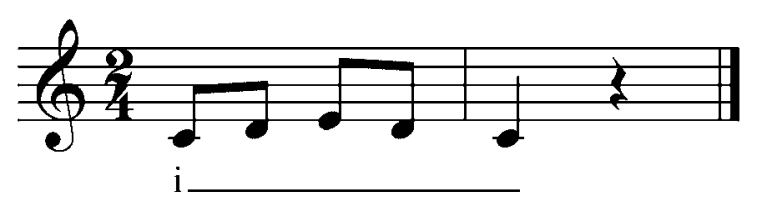


Teve por finalidade aproveitar a questão de colocação vocal iniciada no exercício anterior, para obter um melhor resultado sonoro para a articulação de vogais.

Para concluir essa etapa do ensaio, Caiti passou a oportunidade para o aluno regente Márcio Ocon realizar um exercício que teve bastante êxito no desenvolvimento da escuta melódica dos coralistas, mas desta vez, além deste aspecto também foi trabalhada questão de pergunta e resposta entre as vozes, necessário a execução da peça $O$ Anel. Quando Caiti retornou para trabalhar esta música, o resultado foi bastante satisfatório e a resposta dos novos coralistas foi muito boa, facilitando a aprendizagem e a execução da obra.

A estratégia do ensaio foi montada para que os novos coralistas pudessem ouvir as músicas de dentro do coro, de forma que estivessem estimulados a se envolverem ativamente na realização musical. Observando que “(...) o processo de aprender pressupõe uma mobilização cognitiva desencadeada por um interesse, por uma necessidade de saber” (SOLÉ, 2004, p. 31), esta condição foi estimulada neste ensaio, o interesse estando centrado no fato das pessoas serem voluntárias em participar do coro, e a necessidade de voltar a ensaiar em naipe é desencadeada pelo fato dos novos precisarem aprender as peças para acompanhar os demais. Esta escolha pedagógica, segundo vemos na avaliação, foi eficiente, melhorando os resultados adquiridos em todas as peças ensaiadas neste dia.

Neste ensaio foram trabalhados os seguintes aspectos freqüenciais:

- Afinação das alturas;

- Cantar intervalos melódicos ascendentes e descendentes;

- Memorização melódica;

- Correção e qualidade na realização dos fraseados da música;

- Manutenção da afinação ao longo da peça;

- Fraseado;

- Consciência física da emissão sonora (memória da tessitura);

- Postura corporal geral do coro;

- Consciência auditiva do próprio som;

- Consciência e compreensão melódica;

- Percepção das outras vozes; 
- Promover a prática do canto coral a 2 e 3 vozes e a habilidade para tanto;

- Promover a prática da performance pública.

Como o ingresso de novos coralistas tem se configurado uma característica freqüente dentro desse processo, sugiro que todos os pontos abordados hoje devam continuar a ser estimulados, mas sempre com o cuidado de utilizar situações diversas para a prática não se tornar repetitiva ao invés de reflexiva. Para tal, não podemos deixar de considerar o pensamento de Costa (já citado neste trabalho) que relaciona o desenvolvimento das habilidades do indivíduo a quantidade e a qualidade de estímulos a ele apresentados.

\subsection{Avaliação de 29/10/2008}

A avaliação do ensaio foi realizada pelo aluno regente Márcio Ocon, que fez a seguinte descrição das atividades realizadas neste dia:

OBJETIVOS DO ENSAIO: Terminar a leitura da música Medieval Gloria, e o trabalhar com as peças Minno Amor e Tres Morillas m'enamoram.

O ensaio foi bem produtivo e apresentou, como felizmente vem acontecendo, uma boa dinâmica nas seqüências das atividades.

A preparação vocal foi conduzida por mim, e em minha abordagem frente ao coro procurei focar de forma muito enfática o aspecto da respiração, e isto, em função das orientações que o Professor Marco Antonio realizadas no ultimo ensaio que esteve presente. Acredito que este é seguramente o melhor caminho a seguir em função do momento em que o coro está.

Iniciei com exercícios de relaxamento e alongamento, e posteriormente com exercícios de respiração. Um ponto principal que chamei a atenção foi a tomada de ar, onde normalmente os problemas começam. Então, orientei os coralistas a fazerem uma tomada de ar calma e a observar o efeito de relaxamento e de liberdade que ela deveria propiciar contrastando com a tensão da respiração alta. 
Nos vocalizes procurei trabalhar mais a região central sem, principalmente com as vozes agudas, ir até aos registros mais agudos. Para isso utilizei exercícios de curta extensão com uma predominância nas vogais fechadas. Num determinado momento dos vocalises aproveitei para descer com as vozes graves e pudemos observar um coralista iniciante no grupo sem experiência coral com um considerável potencial. A professora Susana estava presente no ensaio e contribuiu enormemente, não só para a preparação vocal mais também para todo o ensaio.

No ensaio de naipe terminamos a leitura da musica Gloria Medieval.

No ensaio geral o coro rendeu muito bem com a música Medieval Gloria. A aluna regente Caiti conseguiu fazer a montagem da obra de forma muito eficiente e trouxe uma boa concentração ao coro. Na música Tres Morillas procurei trabalhar de forma mais insistente a linha dos baixos, principalmente pela presença do mestrando John e também pelo considerável número de coralista que ainda não aprenderam a música completamente. Após algumas execuções o resultado foi ganhando mais consistência. Entretanto, com a obra Miño Amor o coro a aluna regente Caiti conseguiu atingir um do melhores momentos que esta peça já teve, e de uma forma até uma pouco inesperada. A aluna regente Caiti que a principio achou que seria mais produtivo ceder seu tempo de ensaio para continuar o trabalho com a música Tres Morillas, e que pela nossa insistência na continuidade do seu trabalho para que o grupo não perdesse o contato com a música, conseguiu um momento muito importante do coro.

\section{Análise do Ensaio:}

Neste dia o aluno regente Márcio ficou responsável pelo trabalho de aquecimento vocal e fez uma opção de abordagem bastante eficiente. Segundo Kohut (1990 apud Costa, 2005, p. 80) “A respiração é talvez o mais importante fator isolado e é diretamente dependente da boa postura. Sem um bom controle do suprimento de ar, a voz não pode funcionar eficazmente e a afinação correta não pode ser mantida”. Amparado por este princípio notamos que o trabalho de Márcio durante o vocalise buscou este objetivo, pois em sua abordagem procurou desenvolver a percepção da musculatura utilizada para o canto, observando o trabalho de Snizhana Drahan (2007, p. 19) vemos que “o papel da sensação muscular ajuda tanto a reconhecer a altura e a potência da voz, quanto administrá-las”. Em seguida, Márcio fez outra escolha adequada. Optou por trabalhar os exercícios de vocalise em uma região vocal intermediária, de forma que todos pudessem atingir sua melhor perfomance na entoação das linhas melódicas escolhidas. Depois de ter aquecido as vozes dos coralistas, 
ele aproveitou para experimentar o potencial de extensão vocal dos participantes, principalmente com o naipe dos baixos, conduzindo a execução em regiões mais graves, fazendo com que eles utilizassem os conhecimentos já adquiridos (vocais, auditivos e de consciência física) usando-os como referência e apoio para explorar suas habilidades.

Observamos então, que desde o primeiro momento do ensaio, todas as atividades escolhidas foram organizadas com o intuito de preparar os coralistas para a obtenção de um bom resultado sonoro, com o trabalho de Márcio oferecendo a orientação necessária para o domínio do campo físico e auditivo e consequentemente atingirem melhores resultados de afinação e do controle vocal. Esta maneira de abordagem para o aquecimento vocal pôde ajudá-los a estabelecer novas relações entre seus conceitos anteriores sobre respiração, voz, emissão ${ }^{27}$ e conteúdos trabalhados, levando-os a modificar sua relação com o processo de aprendizagem diante dos desafios que foram propostos. A organização dos exercícios de vocalise feita por Márcio ofereceu a eles condições para melhorar sua resposta diante das questões tratadas durante o ensaio, acelerando a sua compreensão e o domínio muscular consciente para a execução vocal.

\begin{abstract}
Ao aprender, o que muda não é apenas a quantidade de informação que um aluno possui sobre um determinado tema, mas também sua competência (aquilo que é capaz de fazer, de pensar, compreender), a qualidade dos conhecimentos que possui e as possibilidades pessoais de continuar aprendendo. (MAURI, 2003, p. 88)
\end{abstract}

Então podemos concluir que dentro deste processo de ensino/aprendizagem (que no Comunicantus: Laboratório Coral é objeto de constante investigação e aprimoramento), possibilitar que o aluno (coralista) desenvolva suas habilidades de maneira consciente é condição sine qua non, pois através deste processo ele poderá estabelecer as interligações necessárias ao aprendizado dos futuros conteúdos pertinentes ao fazer musical, principalmente quando observamos as relações que a entoação correta das melodias das músicas e dos exercícios de vocalise tem para a construção da escuta melódica e da afinação coral.

Os bons resultados desta preparação estão contidos na avaliação transcrita acima. Podemos notar que embora o grupo estivesse com muitos coralistas novos, a abordagem de

\footnotetext{
${ }^{27}$ Muitos deles nunca imaginaram que seriam capazes de emitir tais sons e sobre a sua relação com a respiração.
} 
Márcio amparada pelos monitores cantando junto com os naipes e também pelo desenvolvimento auditivo-vocal dos primeiros integrantes deste coro, possibilitaram que em todas as obras ensaiadas o resultado sonoro fosse acima das expectativas, principalmente pela qualidade da afinação das melodias e das simultaneidades geradas durante a execução por todas as vozes.

Neste ensaio foram trabalhados os seguintes aspectos freqüenciais:

- Afinação das alturas;

- Cantar intervalos melódicos ascendentes e descendentes;

- Memorização melódica;

- Correção e qualidade na realização dos fraseados da música;

- Manutenção da afinação ao longo da peça;

- Fraseado;

- Consciência física da emissão sonora (memória da tessitura);

- Postura corporal geral do coro;

- Consciência auditiva do próprio som;

- Consciência e compreensão melódica;

- Percepção das outras vozes.

- Qualidade de afinação dentro dos naipes - afinação das melodias;

- Qualidade de afinação entre os naipes - afinação das simultaneidades;

- Promover a prática do canto coral a 3 vozes e a habilidade para tanto.

3.9. Avaliação de $26 / 11 / 2008$

A avaliação do ensaio foi realizada pelo aluno regente Isaac Terceros que fez a seguinte descrição das atividades realizadas neste dia: 
OBJETIVOS DE ENSAIO: Ensaiar as peças Duas Cirandas e Medieval Gloria.

O ensaio teve um resultado técnico e sonoro muito importante. Começamos com mestrando regente Paulo, que dirigiu os exercícios de preparação muscular. Em continuação o professor Marco Antonio trabalhou em exercícios de consciência da respiração, que foram progressivamente assimilados por todos os coralistas. Logo tivemos os exercícios de aquecimento. O professor foi ouvindo em primeiro lugar cada voz separadamente, em seguida por naipes e finalmente em grupos de agudos e graves. Isto permitiu que casa coralista afinasse corretamente as alturas solicitadas e um único som de conjunto fosse sistematicamente construído.

Passamos ao ensaio geral aonde trabalhada a peça Duas Cirandas pelo aluno regente Renato. Esta peça será apresentada pelo Coral Oficina junto com o Coral Escola no dia 7 de Dezembro na apresentação do MASP. Foram trabalhados vários detalhes da interpretação, do equilíbrio dos naipes e das frases em cada parte da obra. O professor deu algumas sugestões e indicações sobre gestos e do aluno regente. $\mathrm{O}$ resultado obtido foi muito bom.

Posteriormente a aluna regente Caiti trabalhou a peça Medieval Gloria, que é a última peça a ser ensaiada durante o este semestre. Decidimos primeiro fazer um ensaio por vozes graves e agudas e logo passamos a um ensaio geral tendo conseguido ótimos resultados.

Análise do Ensaio:

O ensaio teve um resultado técnico e sonoro muito importante. Começamos dirigindo os exercícios de preparação muscular. Em seguida o professor Marco Antonio trabalhou exercícios de consciência da respiração, que foram progressivamente assimilados por todos os coralistas. Logo tivemos os exercícios de aquecimento vocal, onde o professor foi ouvindo em primeiro lugar cada voz separadamente, em seguida por naipes e finalmente em grupos de agudos e graves. Isto permitiu que cada coralista afinasse corretamente as alturas solicitadas, observando como cada um de seus colegas ia conseguindo entoar a voz, as bases de técnica colocadas pelo professor com cada um e até o timbre que cada coralista possuía. Este procedimento propiciou que um único som de conjunto fosse estabelecido, de forma extremamente sistemática, naquele ensaio. A cada dificuldade, o Prof. Marco Antônio ia dando explicações de como se utilizava a técnica correta para cantar, fazia demonstrações 
sobre a respiração e gradativamente ia construindo juntamente com o coro uma melhor emissão sonora. Este trabalho também interferiu positivamente na escuta do coro, levando a todos a emitirem um som condicionado e inter-relacionado ao dos colegas, de forma que a escuta influenciasse a entoação.

O resultado adquirido através desse trabalho do Prof. Marco Antonio nos leva a considerar algumas questões relativas à aprendizagem a partir da construção do conhecimento pessoal de cada aluno. Segundo Mauri (2003, p. 86), construção do conhecimento é “a idéia de que aprender algo equivale a elaborar uma representação pessoal ${ }^{28}$ do conteúdo objeto a ser aprendido". Vemos que, para chegar a esse resultado, houve um longo processo de desenvolvimento de habilidades, aprendizagem e construção de conteúdos musicais, vocais, auditivos dentre outros já citados neste trabalho, sempre de maneira planejada e articulada para que tais conteúdos se complementassem ao longo do processo de ensino/aprendizagem, com o apoio da equipe de monitores sempre interagindo com os coralistas, de forma que seus conhecimentos fossem estabelecidos a partir das experiências musicais e sonoras durante os ensaios. As ações do Prof. Marco Antonio neste momento dirigiram o coro para que utilizassem os conhecimentos e habilidades desenvolvidos ao longo deste ano, e sua conduta durante tal atividade foi a seguinte: "O professor se torna um participante ativo do processo de construção de conhecimento, cujo centro não é a matéria, mas o aluno e a aluna que atuam sobre o conteúdo que devem aprender” (MAURI, 2003, p. 87).

Esta postura pode levar a resultados mais efetivos e duradouros, fazendo com que os conhecimentos possam ser utilizados em outras situações, por terem sido estabelecidos de forma consciente e não pela simples repetição de atividades musicais. Quando começamos o ensaio geral, observamos que o vocalise mudou completamente a relação do coro com a peça (Duas Cirandas), pois ficou mais nítido para eles quando falávamos de equilíbrio vocal, timbre, variação da intensidade do som dentre outros aspectos musicais. A resposta do grupo às orientações do aluno regente Renato e do Prof. Marco Antonio foi muito mais efetiva e precisa, pois era nítido em sua atitude que estavam compreendendo o que era pedido e já sabiam executar.

Com a música seguinte, Medieval Gloria, segundo o relato do aluno regente Isaac a evolução se confirmou. Esta obra teve um papel muito importante para desenvolvimento do

\footnotetext{
${ }^{28}$ Itálico do próprio autor.
} 
coro, mesmo não tendo sido possível deixá-la completamente pronta, os aspectos musicais que ela nos levou a trabalhar foram de grande importância para o aprendizado do grupo e também para nosso aprendizado como regentes e educadores, de forma a nos preparar para a tarefa de formação de novos grupos corais.

Neste ensaio foram trabalhados os seguintes aspectos freqüenciais:

- Afinação das alturas;

- Memorização melódica;

- Manutenção da afinação ao longo da peça;

- Fraseado;

- Consciência física da emissão sonora (memória da tessitura);

- Postura corporal geral do coro;

- Consciência auditiva do próprio som;

- Consciência e compreensão melódica;

- Percepção das outras vozes.

- Qualidade de afinação dentro dos naipes - afinação das melodias;

- Qualidade de afinação entre os naipes - afinação das simultaneidades;

- Promover a prática do canto coral a 2 e 4 vozes e a habilidade para tanto.

Esta foi a última avaliação do ano e estava próxima uma apresentação pública, que seria a primeira mais importante ${ }^{29}$, juntamente do Coral Escola Comunicantus, realizada no Grande Teatro do MASP, em São Paulo, por esse motivo, houve grande preocupação em atingir um bom resultado de afinação. O trabalho que Márcio realizou neste dia foi fundamental para atingirmos tal meta. O coro teve uma performance muito boa ao lado do Coral Escola, mesmo estando em um ambiente diferente ao dos ensaios ao longo do ano, o que pode ser ver foi um grande envolvimento dos coralistas durante toda apresentação, desde

\footnotetext{
${ }^{29}$ O coro já havia participado de um ensaio aberto realizado na Semana de Arte e Educação da ECA-USP no mês de setembro do mesmo ano, que ocorreu na sala 14 do Departamento de Música (DMU), onde ocorrem os ensaios do Coral Oficina Comunicantus. No dia estavam presentes além dos coralistas, alguns monitores integrados a outros coros do Comunicantus: Laboratório Coral.
} 
a chegada, a preparação, a concentração e todos os aspectos que envolvem um concerto. O que pudemos observar ao final desta etapa, que foi encerrada com a participação neste evento, foi uma enorme satisfação estampada no rosto de todos os integrantes do coro pelos resultados atingidos ao longo de todo o ano de trabalho.

$1^{\circ}$ Semestre de 2009

3.10. Avaliação de 04/03/2009

Esta avaliação refere-se ao primeiro ensaio do Coral Oficina em 2009, e tratava-se de um momento muito aguardado, sobretudo, pois, conforme citamos anteriormente, o trabalho de 2008 foi encerrado com um concerto onde o coro se apresentou em conjunto com o Coral Escola no grande auditório do MASP, em São Paulo, realizado no dia 07 de dezembro, onde o coro fez sua primeira grande apresentação pública, fato que gerou certa expectativa na equipe do Comunicantus: Laboratório Coral em relação ao retorno no ano seguinte. Vou transcrever na íntegra o relatório de ensaio de 04 de março de 2009, que teve o seguinte plano de ensaio descrito pelo aluno regente Márcio Ocon, responsável pelo seu planejamento:

OBJETIVOS DO ENSAIO: Receber novos coralistas, apresentando-lhes o trabalho do Comunicantus: Laboratório Coral e do Coral Oficina. Fazer a classificação vocal dos cantores novos. Trabalhar o cânone Viva a Música, de Michael Praetorius.

A avaliação do ensaio foi realizada pela aluna regente Caiti Hauck que fez a seguinte descrição das atividades realizadas neste dia:

O ensaio iniciou-se com muitos coralistas novos e somente 3 cantores que participaram dos trabalhos no semestre anterior. A professora Susana falou sobre o Laboratório Coral Comunicantus e suas atividades, assim como sobre o trabalho realizado no Coral Oficina. Em seguida, pediu que todos se apresentassem, citando nome, curso e eventuais conhecimentos musicais. 
Às 18:25 teve início o aquecimento vocal, dirigido por mim. Fizemos um exercício de consciência corporal, no qual movimentamos e nos conscientizamos de nossas articulações (pulsos, cotovelos, ombros, cintura/quadris, joelhos e pés). Fizemos alguns alongamentos, sempre buscando preparar o corpo para estar em boa postura para cantar. O primeiro exercício vocal foi o bocejo, repetido várias vezes, seguido do "Ah da surpresa” (exercício proposto pelo prof. Giorgio Monari em sua vinda a SP em 2008). Logo depois fizemos exercícios de vibração labial (com "br"), subindo e descendo em altura.

Em seguida, foram realizados exercícios de respiração, nos quais eu expliquei a importância do uso da respiração baixa (diafragmática) ao cantar. Primeiramente, pedi aos coralistas que soltassem o ar em "s", se conscientizando de sua respiração; depois, alternamos soltar a respiração com um "s" longo de quatro tempos, seguido de quatro "s" curtos (quatro semínimas em staccatto).

Seguindo, expliquei aos coralistas o que é o bocca chiusa, para desta forma cantarmos o desenho melódico abaixo.

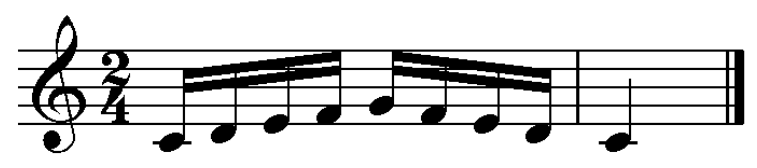

Por fim, cantamos a mesma melodia com as vogais "i” e “o".

Depois do aquecimento, eu iniciei o trabalho com o cânone Viva la Música, de Praetorius. Os coralistas não apresentaram muita dificuldade para aprender a peça; repetimos o cânone em uníssono algumas vezes e a atividade foi finalizada executando o cânone a duas vozes (homens e mulheres).

Às 18:45 a professora Susana e eu iniciamos a classificação vocal dos novos coralistas, que se estendeu até o final do ensaio.

Análise do ensaio:

Como é comum em todo início de semestre, o ensaio começou pela apresentação dos coralistas, para fortalecer as relações estabelecidas pelo grupo que são determinantes para a criação de interesse pela atividade coral e seu bom desenvolvimento. Segundo Solé (2003, p. 50 e 51): "Para atribuir o sentido necessário que nos permitirá envolver-nos realmente em uma tarefa, ela deve nos parecer atraente, deve nos interessar, devemos poder perceber que 
ela preenche uma necessidade; essa necessidade pode então funcionar como motor da ação”. Todos os conteúdos trabalhados em um coro, mesmo que por vezes sejam de cunho individual, como questões relativas às necessidades de aprendizagem que cada coralista possui, têm como objetivo melhorar os aspectos coletivos como a qualidade sonora, a afinação, o timbre, sincronia entre os naipes, o ritmo dentre outros, e quanto melhores forem as relações de convivência, cordialidade e afetividade estabelecidas entre os coralistas, melhores podem ser os resultados que dependem das interações entre eles.

Após as apresentações formais, o ponto escolhido para iniciar o trabalho foi na área de consciência corporal, através de alongamentos físicos. Este aspecto é de grande ajuda na qualidade da emissão sonora, pois predispõe e prepara o coralista para a atividade musical e orienta a postura física necessária para cantar. A aluna regente Caiti, através de seu trabalho, direcionou os coralistas a perceberem como a musculatura utilizada para o canto deveria funcionar. Ela utilizou três exercícios com objetivo de relaxar e preparar a região maxilar para o canto, e também para fazer com que os coralistas percebessem a ressonância que é utilizada para tal. Em seguida, explicou sobre o funcionamento do diafragma para iniciarem sua conscientização da musculatura empregada na respiração baixa e no canto, explicando seu funcionamento e realizando exercícios para seu desenvolvimento. Desta forma, ela buscou em seu trabalho, levar o coralista a atingir um melhor controle de sua respiração diafragmática, a partir da reaprendizagem dessa forma de respiração, que é inerente ao ser humano quando nasce, e que, com o passar do tempo, perde-se, por uma série de fatores culturais e sociais. Seu domínio exige que coralista desenvolva uma nova consciência física em relação a sua respiração, adaptando-se a essa outra maneira de utilizar seu aparelho respiratório.

Após estas atividades, Caiti realizou um aquecimento vocal onde trabalhou outros exercícios de ressonância e também de articulação de vogais, fundamentais ao desenvolvimento do canto e da percepção da sonoridade do coralista. Os objetivos escolhidos foram bastante específicos, o trabalho foi todo direcionado para emissão vocal, que implica na entoação de melodias utilizadas nos vocalizes, onde se inicia o trabalho da escuta melódica e a emissão vocal a partir da percepção do som produzido através da utilização do diafragma, desenvolvendo duas novas consciências: física e auditiva sobre a forma de usar o aparelho respiratório e fonador.

Em seguida a aluna regente Caiti ensinou aos coralistas um cânone. Esta escolha foi amparada pela vasta experiência do Prof. Marco Antonio e da Prof. a Susana Igayara que apontam para a quantidade de conteúdos musicais que são trabalhados nesta modalidade de 
composição musical, consideramos que se trata de uma peça adequada ao aprendizado de iniciantes em canto coral, pois através dele podem ser trabalhados a afinação coletiva, a sincronia, a memória, a escuta melódica, a percepção melódica, a consciência de voz do coralista junto às outras vozes dentre outros diversos aspectos, e o desenvolvimento de tais habilidades pode levar ao coro a obter mais facilidade para aprender e cantar em vozes separadas. Desta forma, tal escolha pode determinar o resultado pretendido. Segundo Milagro Brünner, educador e regente espanhol: “O repertório será o eixo central, pois com a seqüência gradual necessária, irá aumentar o desenvolvimento do coro ${ }^{30 ”}$ (BRÜNNER, 2009, p. 13).

Desta forma, a utilização de um cânone nesse momento de retomada de trabalho, onde poderíamos ter (e de fato tivemos) vários candidatos novos e sem experiência musical às vagas do coro, foi uma opção completamente apoiada em dois aspectos. O primeiro é o fato de ser mais fácil de aprender, pois todos os naipes do coro cantam a mesma melodia não sendo necessário um grande desenvolvimento musical para conseguir fazê-lo, e o segundo é que através da escuta e da execução da mesma melodia por todos é que se começa a criar uma consciência melódica coletiva, facilitando posteriormente, que o grupo consiga mais facilmente executar peças compostas a mais vozes. Assim sendo, a escolha adequada do repertório, sempre ajustada ao nível de desenvolvimento atual do coro, fará toda a diferença no resultado final, pois este fator é que irá aproximar o novo conteúdo aprendido dos conhecimentos prévios que os coralistas já possuem.

Dentro do pensamento construtivista de ensino/aprendizagem são utilizados dois conceitos que são fundamentais para este trabalho. O primeiro é o conceito piagetiano “conhecimentos prévios”, e o segundo é o conceito que Vigotsky chamou de Zona de Desenvolvimento Proximal. Sabemos da vasta literatura existente para tratar as questões relativas à aprendizagem e ao desenvolvimento, mas optamos por utilizar tais autores, por serem embasadores de inúmeros outros trabalhos, alguns dos quais são de extrema relevância para o seguimento dessa investigação. Segundo eles, as crianças aprendem a partir interligação desses dois conceitos, e no caso do trabalho com adultos é perfeitamente possível partir do mesmo princípio, pois podemos utilizar as experiências e conhecimentos que já possuem, para, a partir deles estabelecer suas novas referências para a aprendizagem. Para tanto, precisamos primeiro entender o que são estes dois conceitos e como eles se encaixam no contexto da aprendizagem musical.

\footnotetext{
${ }^{30}$ Tradução nossa: El repertorio será el eje central que, con la debida graduabilidad y secuencia, dará crecimiento al desarrollo del coro.
} 
Segundo a educadora espanhola Mariana Miras, conhecimentos prévios são:

[...] os conhecimentos que já possuem sobre o conteúdo concreto que se propõem a aprender, conhecimentos prévios que abrangem tanto conhecimentos e informações sobre o próprio conteúdo como conhecimentos que, de maneira direta e indireta, estão relacionados ou podem relacionar-se com eles (MIRAS, 2004, p. 60).

Assim consideramos que todas as pessoas que se dispõem a ingressar em um coral trazem consigo informações que podem ser utilizadas para facilitara aprendizagem dos conteúdos a serem abordados. Tal conceito nos mostra um caminho muito amplo para realizar nosso trabalho, com o pensamento que sempre aproveitar o que os coralistas já sabem de alguma maneira em nosso trabalho. As diversas experiências musicais, sonoras e sensórias adquiridas por eles ao longo de suas vidas poderão servir como referência para algum aspecto ou conteúdo abordado durante o processo de ensino/aprendizagem.

Falemos agora do conceito Vigotskiano Zona de Desenvolvimento Proximal, que nesta dissertação trataremos de ZDP, como de praxe nos textos e práticas que com ele lidam.

[...] a ZDP é definida como a distância entre o nível de resolução de uma tarefa que uma pessoa pode alcançar atuando independentemente e o nível que pode alcançar com a ajuda de um colega mais competente ou experiente nessa tarefa (VIGOTSKY, 1979 apud ONRUBIA, 2003, p. 127)

[...] a ZDP pode ser definida como o espaço no qual, graças à interação e a ajuda dos outros, uma pessoa pode trabalhar e resolver um problema ou realizar uma tarefa de uma maneira e em um nível que não seria capaz de ter individualmente (NEWMAN, GRIFFIN e COLE, 1991 apud ONRUBIA, 2003, p. 128)

Deste modo então concluímos que a aprendizagem de novos conteúdos como consciência física, aspectos auditivos, físicos como “respiração diafragmática”, emissão vocal e os conteúdos puramente musicais como a escuta melódica, entre outros, que estão intrinsecamente ligados à realização e à aprendizagem musical, tem seu processo facilitado pela integração do grupo coral. Amparando-nos no pensamento de educadores construtivistas que atuaram na reforma educacional na Espanha "que defende a importância da relação e da interação com outras pessoas como origem dos processos de aprendizagem e desenvolvimento humanos” (Onrubia, 1998, p. 127), observamos que o aprendizado de determinados conteúdos 
em ambiente coletivo pode atingir níveis mais satisfatórios do que se ocorressem individualmente, de maneira que os indivíduos com maiores dificuldades podem ter seu aprendizado facilitados pela influência de outros indivíduos do grupo mais experientes ou mais desenvolvidos em relação aos conteúdos trabalhados.

Sendo assim, a partir da verificação das avaliações de ensaio, dentro dos parâmetros definidos para a realização desta análise de procedimentos e conteúdos musicais, repontuamos os seguintes conteúdos trabalhados neste ensaio do coro:

- Afinação das alturas;

- Cantar intervalos melódicos ascendentes e descendentes;

- Consciência física da emissão sonora;

- Postura corporal geral do coro;

- Memorização melódica;

- Correção e qualidade na realização dos fraseados da música;

- Consciência auditiva do próprio som;

- Percepção das outras vozes;

- Manutenção da afinação ao longo da peça.

3.11. Avaliação de 25/03/2009

A avaliação do ensaio foi realizada pelo aluno regente Márcio Ocon que fez a seguinte descrição das atividades realizadas neste dia:

OBJETIVOS DO ENSAIO: Ensinar a música "Na Bahia Tem”.

O mestrando regente Paulo Lopes iniciou a preparação vocal com exercícios de relaxamento e alongamento. Através de uma serie de exercícios combinados para a soltura dos braços, pescoço e ombro, e também a conscientização da postura, ele trouxe ao grupo concentração física e mental 
necessária para iniciar o condicionamento respiratório. Abaixo temos o primeiro exercício utilizado:

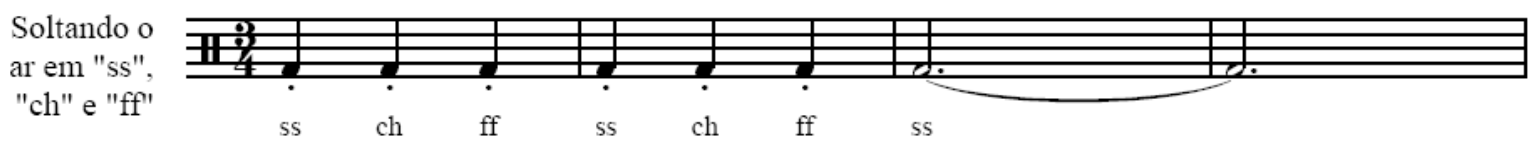

Posteriormente acrescentado de um compasso a mais:

Sotando o

ar em "ss",

"ch" e "ff"

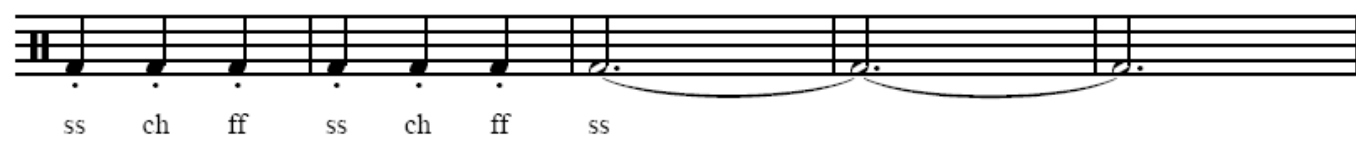

Seguiu-se com um exercício de controle do ar: inspira em 2, segura em 2 e solta em 2; depois inspira em 2, segura em 2 e solta em $4(6,8,10, \ldots 16)$.

Antes do primeiro vocalize o mestrando regente Paulo explicou aos coralistas o que é o bocca chiusa, para desta forma iniciar o exercício abaixo.

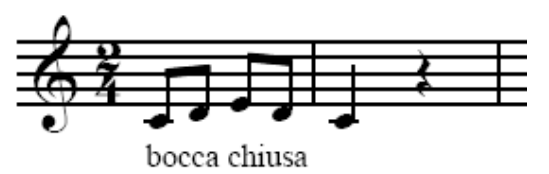

Durante esse exercício o mestrando regente Paulo chamou a atenção do grupo para o uso da ressonância alta e o resultado sonoro foi muito melhor.

No exercício seguinte, a cada modulação foi se alternado as vogais $i, e, a, o, u$.

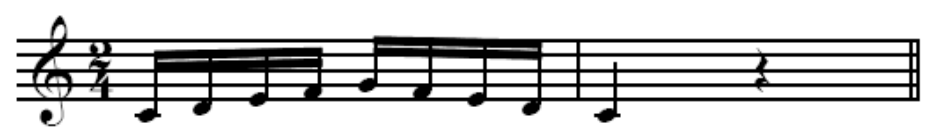

Os exercícios seguintes foram utilizados para trabalhar a extensão vocal. 

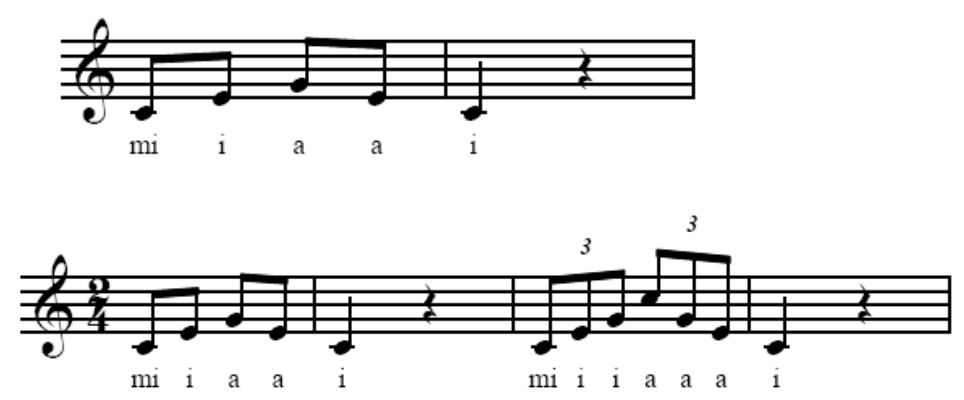

A preparação vocal foi bem simples, porém, muito eficiente e tinha objetivos pedagógicos muito claros. Com as orientações que soube trazer o mestrando regente Paulo Lopes soube construir todo um processo de ensino do canto coletivo.

Após a preparação vocal tivemos o ensaio de naipe.

O ensaio geral iniciou pouco antes das 19h com o aluno regente Rodrigo. Primeiramente ele deu algumas instruções ao grupo em relação ao ato de cantar em grupo, falou da questão das entradas dos naipes que iniciam a música e dos vários ritornellos. Posteriormente iniciamos o primeiro ensaio geral. $\mathrm{O}$ resultado obtido, se levarmos em consideração a inexperiência do grupo, foi muito bom. O grupo ficou muito satisfeito. Alguns dados importantes: o contralto estava fazendo um movimento que prejudicava a afinação (na parte do texto em que elas cantam tem, tem, tem), o que foi muito bem apontado pelo aluno regente Rodrigo, entretanto, apesar disso, nós, coralistas não conseguimos consertar o problema. Outra observação é que precisamos lembrar sempre de não gastar tempo em explicações que trazem pouco resultado, como a professora Susana tem dito algumas vezes "é mais fácil fazer do que explicar”.

Devemos continuar com o trabalho de respiração como o mestrando regente Paulo Lopes está fazendo, e, cada vez mais, mostrar e fazer com que o grupo perceba a sua importância.

Também acho muito importante já termos outra música em mente para os próximos ensaios, algo novo na semana que vem, mesmo que simples, pode manter um ritmo interessante de aprendizado, ou seja, uma música nova a cada encontro... Vamos discutir.

Análise do ensaio:

Logo de início pudemos perceber uma evolução do coro nos aspectos vocal e melódico. Os exercícios utilizados, desde os de respiração até os de aquecimento vocal foram executados num melhor nível qualitativo. Observe-se que é seguida uma rotina de 
procedimentos que proporciona aos coralistas uma aprendizagem continuada, fixando os conceitos trabalhados até a total assimilação física e mental, fazendo com que esses conteúdos possam ser incorporados gradativamente à habilidade de cantar. Houve uma variação na tipologia dos exercícios de respiração com o objetivo de aumentar o controle de diafragma dos coralistas, principalmente porque da maneira como a atividade foi realizada o controle consciente da retomada e do gasto do ar começou a ser desenvolvido, o que é uma habilidade fundamental para a emissão das notas longas, da sustentação melódica no canto coral e da evolução da afinação vocal do grupo.

Nos exercícios de aquecimento e preparação vocal eram minhas preocupações naquele momento os aspectos de ressonância, articulação de vogais, emissão vocal e consciência física a partir de exercícios melódicos. Por estes motivos não utilizei exercícios com nível de complexidade elevado, mas sim ajustados às possibilidades técnicas do coro, de maneira que todos conseguissem realizar, preparando ao grupo para a superação de questões de outra ordem que também interferem no resultado pretendido.

[...] vários fatores podem prejudicar a emissão vocal, entre eles, as tensões musculares, os problemas respiratórios e o uso inadequado do registro vocal. Esses fatores podem estar inter-relacionados sem que se possa definir seus limites (SOBREIRA, 2003, p. 69).

Por causa disto utilizamos também exercícios que fossem nessa direção, ou seja, buscando solucionar as questões físicas da emissão vocal para assim obter um melhor resultado sonoro e de afinação, objetivo que, segundo a descrição de Márcio em seu relatório foi alcançado durante o vocalise.

O objetivo principal deste ensaio foi ensinar para o coro a música $\mathrm{Na}$ Bahia tem, o que levou a equipe de monitores a criar um trabalho voltado para as questões de ensino/aprendizagem do aspecto melódico da peça, que se deu através dos ensaios de naipes. Para isto foi criada uma estratégia aonde cada monitor responsável por seu naipe iria ensinar ao grupo a música do início ao fim com o primeiro verso do texto, observando que por se tratar de uma peça a quatro vozes cada naipe tem sua própria linha melódica, o que implica em um aprendizado muito bem estruturado para que na hora de juntar os naipes, cada um deles consiga cantar sua linha sem sofrer influência das outras. Isto requer do regente a habilidade de criar uma estratégia para a melhor apreensão do conteúdo melódico pelos coralistas. A estratégia escolhida foi a do ensino através do desenvolvimento da memória 
melódica, onde o regente, apoiado pelo piano, ensina trechos curtos da peça que aos poucos são juntados até a conclusão.

Após o ensaio de naipes o coro se reuniu para o ensaio coletivo, e então foi possível verificar o resultado da estratégia que os monitores utilizaram em seus respectivos naipes, que segundo a descrição de Márcio, teve um resultado muito bom. $\mathrm{O}$ aluno regente Rodrigo Báez, que ficou como responsável pelo ensaio coletivo, fez orientações muito bem colocadas sobre os aspectos melódicos da peça, explicando aos coralistas sobre as entradas dos naipes separadamente, dando ao grupo uma noção geral de como é a execução da peça, ensinando a eles em que momento cada naipe iniciaria a cantar sua parte dentro da música.

Mas o aluno regente Márcio, embora tenha gostado do resultado geral da performance do coro, aponta um problema: se ocorre em um determinado trecho da música, aonde o naipe de contraltos não conseguiu cantar corretamente. Nesse fragmento musical específico há uma seqüência de intervalos melódicos descendentes e o que pudemos detectar foi uma dificuldade do coro em manter o apoio diafragmático para cantar. O fato é que a estratégia de ensino da melodia com os naipes não levou em consideração a questão da consciência física dos coralistas, principalmente por ser um grupo sem experiência anterior em técnica vocal. Desta maneira então, os conhecimentos vocais abordados no vocalise precisam ser trabalhados também dentro dos ensaios de naipe, para a obtenção de um melhor resultado vocal. Segundo Costa (2002, anexo 15) "um novo conhecimento ancora-se numa estrutura de conhecimento preexistente (os conhecimentos prévios do individuo)” e, quando não utilizamos estes conhecimentos que os coralistas já dominam, perdemos a oportunidade de completar um estágio de ensino/aprendizagem que possibilitará a seqüência do desenvolvimento do coro.

Sendo assim, a partir da verificação das avaliações de ensaio, dentro dos parâmetros definidos para a realização desta análise de procedimentos e conteúdos musicais, pontuamos os seguintes conteúdos trabalhados neste ensaio:

- Afinação das alturas

- Cantar intervalos melódicos ascendentes e descendentes

- Percepção e capacidade de emissão dos cromatismos

- Consciência física da emissão sonora

- Postura corporal geral do coro 
- Qualidade de afinação dentro dos naipes - afinação das melodias

- Qualidade de afinação entre os naipes - afinação das simultaneidades

- Memorização melódica

- Correção e qualidade na realização dos fraseados da música

- Consciência auditiva do próprio som

- Percepção das outras vozes

- Manutenção da afinação ao longo da peça

- Promover a prática do canto coral a 4 vozes e a habilidade para tanto

3.12. Avaliação de 01/04/2009

A avaliação do ensaio foi elaborada pela monitora Mariana Pilotto Reis que fez a seguinte descrição das atividades realizadas neste dia:

OBJETIVOS DO ENSAIO: Continuar o aprendizado da peça Na Bahia Tem e fazer um trabalho de organização dos naipes do coro.

O mestrando regente Paulo Lopes iniciou o ensaio com alongamento do corpo, melhorando dessa forma a postura dos coralistas, logo em seguida ele iniciou uma série de exercícios de respiração (lembrando sempre a respiração baixa), começando por respirar, segurar em dois tempos e soltar em "s" longo de quatro, seis e dez tempos, em seguida respirar e soltar o ar com altura definida (mi) com o som de "zi".

A escolha da silaba "zi” para este exercício teve muita relação com a qualidade da emissão sonora. O Prof. Dr. Marco Antonio da Silva Ramos, que coordena o Comunicantus: Laboratório Coral chama a atenção para a maneira como o som destes dois fonemas é executados vocalmente, tanto separados quanto juntos. O Prof. Marco explica que o som do fonema "z" só pode ser emitido naturalmente com o apoio do diafragma, o fonema "i” é naturalmente executado com maior projeção sonora, desta forma, quando se juntam combinam o apoio e a projeção do som.

O vocalize foi iniciado com um exercício de bocca chiusa (do re mi fá sol fá mi re do) e o mestrando regente detectou que alguns coralistas estavam tencionando a garganta ao fazê-lo. Sendo assim Paulo Lopes propôs um relaxamento vocal "jogando" a voz do agudo para o grave, melhorando assim o resultado vocal. Em seguida Paulo lembrou a posição das vogais "a e i o u" e realizou um exercício alternando-as. Como foi lembrado na última aula dos monitores, as vozes femininas e masculinas foram separadas nos vocalizes para se identificarem melhor entre si, o que deu um ótimo resultado, pois além da 
identidade vocal melhor fixada foi possível visualizar os problemas dos naipes. No vocalize de vogais alternadas ficou perceptível a falta de apoio dos coralistas na forma descendente do exercício e o ele lembrou-os de apoiar. Após esse vocalize o mestrando regente Paulo Lopes realizou um trabalho muito interessante, baseado na sustentação de nota, o exercício separou novamente homens e mulheres e foi utilizado o fonema "lá” nas notas "sol lá si lá sol”, um naipe fazia a variação (sol lá si lá sol) enquanto o outro sustentava a primeira nota (sol).

Após o aquecimento seguimos para o ensaio de naipe. Tivemos um problema com espaço, pois não havia salas suficientes para todos os naipes e com isso os naipes femininos fizeram o ensaio na mesma sala, sendo assim o ensaio ficou um pouco confuso, pois apesar das dos naipes se completarem alguns problemas não puderam ser tratados com clareza pelo motivo do ensaio ser realizado em função de dois grupos.

O ensaio geral se iniciou com a regência do aluno regente Rodrigo e ocorreu o mesmo problema que havia ocorrido no ensaio anterior que era o "vício" de alguns coralistas de não fixarem a nota no trecho "tem, tem, tem” da música, vício esse que contaminou quase um naipe todo (contraltos), o regente chamou a atenção para isso e o problema foi amenizado um pouco. Houve também algumas entradas indecisas por parte das sopranos por causa do contratempo. Após o ensaio da música Na Bahia tem, o mestrando regente Paulo Lopes regeu o Baião de Ninar, não chegou a se realizar o cânone, mas houve o trabalho de afinação do coro através da sustentação das primeiras notas da música. Esse trabalho deu um ótimo resultado, o coro se concentrou e ganhou muito em afinação.

Neste ensaio realizei a preparação e aquecimento vocal com o objetivo de preparar o coro para a realização de uma atividade para melhorar o aspecto corporal e auditivo. Ela está descrita detalhadamente no sub-item 4.1.1.

Análise do ensaio:

Na aula da disciplina Práticas Multidisciplinares em Canto Coral com Estágio Supervisionado realizada no dia 26 de março, uma semana antes do ensaio relatado anteriormente, foram feitas algumas análises sobre os resultados apresentados pelo Coral Oficina, uma delas foi a da Prof ${ }^{a}$ Susana Cecília Igayara sobre a qualidade dos aquecimentos vocais, onde ela percebeu que o fato dos exercícios serem realizados com homens e mulheres em conjunto não estava alcançando um bom resultado de afinação e altura, pois algumas 
mulheres cantavam oitava abaixo como os homens, e também se passava o contrário com alguns homens cantando oitava acima influenciados pelo som das mulheres. A Prof. ${ }^{\text {a Susana }}$ sugeriu que para o próximo ensaio, a se realizar em $1^{\circ}$ de abril de 2009 (no caso esse), fosse preparado um exercício em que os naipes masculinos e femininos pudessem ser trabalhados separadamente, e assim foi feito e o que se viu foi um melhor resultado de afinação dos dois grupos, possibilitando um maior equilíbrio entre as vozes, sobretudo o naipe de contraltos onde ocorreram as maiores dificuldades pela influência dos naipes masculinos. Elas cantavam as notas sempre na região mais grave de seu registro vocal, o que não ocorreu durante este novo exercício e no restante do vocalise.

Outra questão observada foi que durante a execução de notas longas, ocorria uma grande dificuldade na manutenção de sua afinação, por causa de dois aspectos: o corporal e o auditivo. No aspecto corporal, pois o grupo ainda não possui a consciência física indispensável para o controle diafragmático necessário para a sustentação das notas. E no aspecto auditivo pelo fato de sua percepção musical ser pouco desenvolvida e não identificar pequenas variações sonoras ao cantar, e desta maneira, não percebiam que a sua afinação ia aos poucos se modificando em direção ao grave.

Da mesma forma, quando o aluno regente Rodrigo Báez iniciou o ensaio geral com a execução da peça $\mathrm{Na}$ Bahia tem , o que pode ser observado é que a mesma dificuldade do coro para realizar a sustentação melódica ocorrida durante o aquecimento se configurou também no ensaio coletivo, pois a dificuldade para sustentar as notas longas ocorreu também no momento em que cantavam as melodias descendentes, fazendo com que a afinação ficasse sempre abaixo da freqüência esperada. Este fato ficou registrado pela monitora Mariana no trecho em que ela comenta sobre a dificuldade do naipe de contraltos em sua avaliação. Como no planejamento de ensaio estava programado para que eu regesse a peça Baião de Ninar de Edino Krieger, utilizei o recurso de relembrar com o coro a atividade feita logo após a preparação vocal, para que eles pudessem relacionar os conteúdos trabalhados naquele exercício (ZDP) com a execução da peça de Krieger, fazendo com que percebessem as semelhanças entre as duas atividades e assim estabelecessem esse novo conhecimento, cantando de maneira correta a música ensaiada.

Então, a partir das avaliações de ensaio, dentro dos parâmetros definidos para a realização desta análise de procedimentos e conteúdos musicais, pontuamos os seguintes conteúdos trabalhados neste ensaio: 
- Afinação das alturas;

- Consciência física da emissão sonora;

- Postura corporal geral do coro;

- Consciência auditiva do próprio som;

- Manutenção da afinação ao longo da peça;

- Qualidade de afinação dentro dos naipes - afinação das melodias;

- Percepção das outras vozes;

- Promover a prática do canto coral a 4 vozes e a habilidade para tanto.

3.13. Avaliação de 15/04/2009

A avaliação do ensaio foi elaborada pela aluna regente Caiti Hauck, que fez a seguinte descrição das atividades realizadas neste dia:

OBJETIVOS DO ENSAIO: Iniciar o aprendizado da música "Ponta de Areia” e aperfeiçoar a música "Na Bahia Tem”

Foi um bom ensaio. $\mathrm{O}$ aquecimento foi feito pelo mestrando regente Paulo Lopes e a primeira atividade consistiu em ouvir a própria respiração, fazendo uso do diafragma e soltando o ar em $s$. Em seguida, foram feitos alongamentos de pescoço e ombros.

O primeiro vocalize foi em bocca chiusa, com o desenho melódico abaixo. Este exercício foi feito separadamente por homens e mulheres.

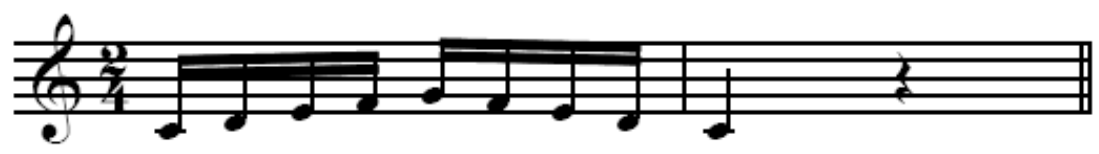

O segundo exercício usava o mesmo desenho melódico, mas desta vez com as vogais $i$ e $o$, e foi realizado com naipes femininos e masculinos juntos.

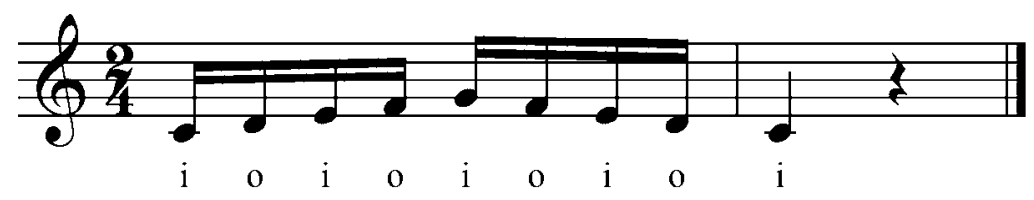


O terceiro e último exercício usava a tríade maior e as vogais $i$ e $a$. Ele foi feito primeiro só com as mulheres, depois só com baixos e por fim só com tenores.

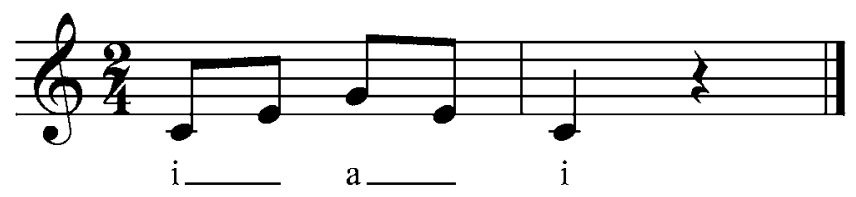

Depois do aquecimento vocal foram realizados os ensaios de naipe, cujo objetivo foi trabalhar a peça Ponta de areia até o compasso 32.

O ensaio geral começou às 18:50 com o aluno regente Renato e a música Ponta de areia. O primeiro aspecto trabalhado por ele foi o contratempo no início das linhas de contralto e tenor com a sílaba ta, que complementa a linha dos baixos com a sílaba Pon; para este trecho, o aluno regente sugeriu que os coralistas cantem internamente o Pon da linha dos baixos. Os dois naipes em questão não apresentaram dificuldades para realizar este contratempo. Em seguida, o aluno regente pediu ao naipe dos baixos que o $n$ da sílaba Pon fosse mais anasalado e executou o início da peça com este naipe. Depois, a peça foi realizada com todos os naipes até o compasso 24 . O aluno regente pediu que os naipes de contralto e tenor façam um decrescendo após os ataques na sílaba ta e executou a peça com todos os naipes até o compasso 32. Por fim, ele pediu que sopranos cantem a sua melodia em legato.

Às 19:05 o aluno regente Rodrigo iniciou o trabalho com a peça $\mathrm{Na}$ Bahia Tem. Após uma primeira execução, o aluno regente trabalhou a linha dos tenores e, em seguida, somente a linha de contraltos. O trecho com a letra tem, tem, tem - que apresenta problemas desde o início do trabalho com esta peça - continua sendo realizado pelas coralistas com aquele indesejável glissando entre as notas. Em relação a isso, o professor Marco Antonio sugeriu que contraltos cantassem com mais malícia ${ }^{31}$, a fim de evitar a queda da afinação. Mesmo assim, o problema não foi totalmente resolvido. Como o ensaio já estava para acabar, o aluno regente Rodrigo executou a peça com todos do começo ao fim.

\footnotetext{
${ }^{31}$ No contexto, o termo malícia se aplica no uso do fôlego, na maneira de gastar o ar, que estava ingênua.
} 
Análise do ensaio:

Novamente coube a mim a atividade de preparação vocal do e optei por continuar mantendo os mesmos exercícios de respiração para que os coralistas incorporassem a maneira como a respiração diafragmática deve ser feita, trazendo elementos de "consciência física da emissão sonora” e “postura corporal geral do coro” para que fiquem cada vez mais presentes dentro das atividades de ensaio. Busquei utilizar a respiração diafragmática de uma forma cada vez mais natural e involuntária, como requer a prática do canto, refletindo na melhoria da qualidade vocal e melódica do coro. Em seguida, começamos os exercícios com uma escala maior em bocca chiusa, extensão do primeiro ao quinto graus, para aumentar o nível de dificuldade do exercício e expandir gradativamente o elemento "memorização melódica” do grupo. Também no mesmo formato como foi realizado no ensaio do dia 01 de abril, trabalhei com os homens separadamente das mulheres, para evitar que o som de um grupo influenciasse o do outro. Nenhum dos naipes apresentou dificuldades em realizar esta seqüência melódica desde a primeira vez. No exercício seguinte utilizei a mesma seqüência, mas substituí o exercício anterior por vogais, buscando reforçar a memória melódica ao acrescentar um novo elemento de aprendizagem, que no caso foi a articulação das vogais “i” e “o”. Como o coro havia cantado muito bem o exercício anterior, para experimentar sua evolução, decidimos realizar este exercício com os naipes todos juntos, mas ainda apresentaram dificuldades com relação ao aspecto "percepção das outras vozes”, com alguns coralistas demonstrando serem influenciados auditivamente por outros, e acabarem cantando em regiões ora mais graves, ora mais agudas que a sua natural. Então decidi voltar a trabalhar com eles separadamente, homens e mulheres. Desta maneira, concluí o vocalise com o exercício que também continha vogais, mas a seqüência melódica utilizada foi um arpejo maior até o quinto grau, que buscou trabalhar os elementos “afinação”, “alturas” e "Cantar intervalos melódicos ascendentes e descendentes” que o arpejo proporciona. O grupo realizou o exercício com facilidade, e a afinação melhorou com os homens cantando separados das mulheres. As deficiências apresentadas foram o fato de cantarem o quinto grau com um acento mais forte, o que foi corrigido com facilidade quando os alertei que isto estava ocorrendo, dando um exemplo de como eles estavam cantando e em seguida, de como deveriam cantar. 
Então o coro se dividiu para o ensaio de naipes, onde foi trabalhada a peça Ponta de Areia, de Milton Nascimento e Fernando Brant, com arranjo coral feito por Marisa Ramires e Antonio Carlos Neves Pinto, a música foi ensaiada até o compasso 24, e a única dificuldade no aspecto melódico foi com relação à execução do naipe de sopranos que cantava a melodia de uma forma quase staccato, apresentando necessidade de aprendizagem no elemento “consciência e compreensão melódica”, de maneira que o aluno regente Renato Spinosa alertou para o naipe a maneira correta de cantar. Nos outros trechos os naipes demonstraram uma boa compreensão desse aspecto.

Quando o aluno regente Rodrigo Báez foi à frente do coro para trabalhar a peça $\mathrm{Na}$ Bahia tem, embora tenha conseguido um bom resultado com o naipe de tenores, o de contraltos continuva apresentando a mesma dificuldade que surgiu alguns ensaios antes, que foi à queda da afinação enquanto cantavam os intervalos descendentes, e isto não foi possível resolver neste ensaio. A mim pareceu uma dificuldade que mesclava questões físicas e de compreensão intelectual para a execução destes intervalos descendentes. Impus-me o objetivo de observar no decorrer dos ensaios seguintes, se a dificuldade permaneceria.

Sendo assim, a partir da verificação das avaliações de ensaio, dentro dos parâmetros definidos para a realização desta análise de procedimentos e conteúdos musicais, pontuamos os seguintes conteúdos trabalhados neste ensaio:

- Afinação das alturas;

- Consciência física da emissão sonora;

- Postura corporal geral do coro;

- Consciência auditiva do próprio som;

- Promover a prática do canto coral a 4 vozes e a habilidade para tanto.

Mediante as necessidades de aprendizagem apresentadas é necessário desenvolver atividades pedagógicas e estratégias de ensaios para melhorar os seguintes elementos: 
- Memorização melódica;

- Qualidade de afinação dentro dos naipes - afinação das melodias;

- Correção e qualidade na realização dos fraseados da música;

- Consciência física da emissão sonora;

- Consciência auditiva do próprio som;

- Consciência e compreensão melódica;

- Promover a prática do canto coral a 2,3 e 4 vozes e a habilidade para tanto.

3.14. Avaliação de 22/04/2009

A avaliação do ensaio foi elaborada pelo aluno regente Renato Spinosa que fez a seguinte descrição das atividades realizadas neste dia:

OBJETIVOS DO ENSAIO: Prosseguir na leitura da peça Ponta de Areia, continuar o trabalho com a música Na Bahia Tem, e fazer um jogo para que todos os envolvidos no coro se conheçam um pouco melhor.

Avalio como um bom ensaio. A aluna regente Caiti foi responsável pelo aquecimento começando com alongamento acompanhado de um exercício respiratório (em 'S', 4 staccatos e um longo de 4 tempos).

O primeiro vocalise foi feito com a melodia abaixo, sendo variado primeiro em bocca chiusa (todos juntos); depois separando mulheres e homens com a vogal 'i'; voltando todos juntos com a vogal 'e' e por fim trocando a cada vocalize pelas outras vogais 'i', 'a', 'o' e 'u'.

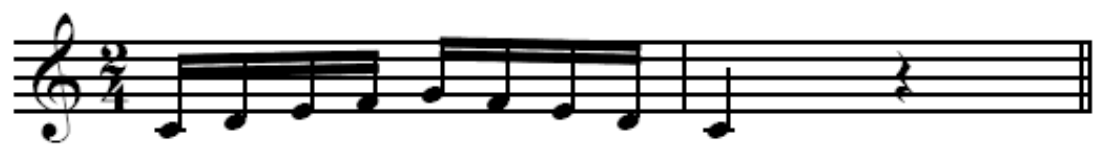

O segundo também foi feito com homens e mulheres separados e usava a melodia abaixo:

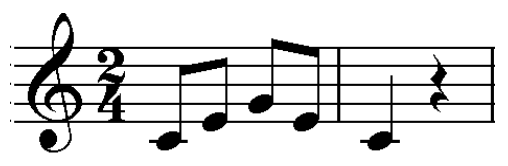

Pra ia ia ia ia 
O terceiro exercício foi com arpejos com extensão de uma oitava e as vogais i-o-i. Ele foi aplicado separando vozes graves e agudas. Vale observar que neste exercício as vozes agudas conseguiram alcançar uma região bastante alta da tessitura, se considerarmos que são coralistas iniciantes.

O último vocalize foi o de sexta acrescentada com as sílabas vi-i-vo. Nele os naipes graves, em especial os baixos, apresentaram dificuldade para executar já na região média da voz, com alguns cantores estacionários inclusive.

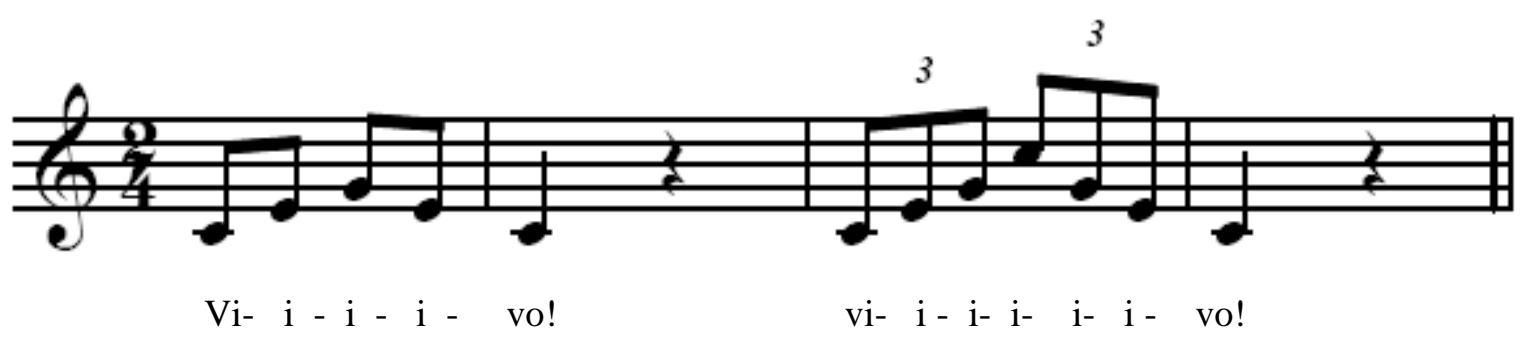

Depois do aquecimento o coro se separou para os ensaios com os 4 naipes separados, com a intenção de (se possível) ler a música Ponta de Areia até o final e caso sobrasse tempo, relembrar a música já aprendida Na Bahia tem.

Voltando ao ensaio geral que começou às 18:50 comigo ensaiando a música Ponta de areia. O primeiro objetivo do ensaio geral era tentar registrar a harmonia inicial da música com os coralistas; para isso foi pedido apenas aos naipes que acompanham a melodia principal que entoassem em bocca chiusa suas notas iniciais e as subseqüentes, com atenção voltada para a escuta e afinação do acorde. Observei que os cantores apresentaram mais dificuldade para afinar esse acorde no exercício em bocca chiusa do que ao cantar com a parte rítmica da partitura, por isso o exercício não foi insistido nesse ensaio. Em seguida, o naipe de sopranos se somou aos outros e foi passada uma vez com todas as vozes. Assim como no ensaio anterior, foi pedido às sopranos que entoassem a melodia de forma mais ligada, e enfatizando isso foi pedido para que elas não pensassem na melodia como nota por nota. No começo da segunda página da música, o naipe de contraltos apresentou dificuldade para cantar a melodia de 'caminho de ferro...' junto às outras vozes. Com isso a melodia foi relembrada ao piano e trabalhada apenas junto às sopranos. Mesmo com contraltos não estando completamente seguras, retornei ao trabalho com todas as outras vozes, para que tomassem conhecimento de como se sucede o arranjo com as vozes juntas, terminando assim o ensaio dele.

Às 19:07 o aluno regente Rodrigo assumiu o ensaio geral com a música $\mathrm{Na}$ Bahia Tem, executando duas vezes inteiras a música com as três letras. Durante esse ensaio observei alguns pontos que acredito que deveriam ganhar mais atenção. O primeiro é a entrada de contraltos, em que elas ainda demonstram dificuldade para cantar a tríade, que sempre sai com problemas de afinação. Outro lugar crítico 
para contraltos é no momento em que dobra em $3^{\mathrm{a}}$ com sopranos, onde elas se confundem e acabam por vezes cantando junto com o outro naipe.

Os tenores, que estavam desfalcados nesse ensaio, ainda apresentam dificuldade no 'cantarolando' do final da música, que sugiro que seja reaprendido no próximo ensaio de naipes.

E por fim o naipe de baixos, que ainda não consegue entrar sincronizado com os outros naipes.

Analise do Ensaio:

Neste vocalise conduzido pela aluna regente Caiti Hauck, pudemos notar uma seqüência progressiva dos exercícios de respiração. Quando ela optou por trabalhar os staccati, acrescentou outro nível de dificuldade, pois para executar este exercício é necessário ter concentração para controlar os movimentos do diafragma durante o trabalho vocal, e nesse caso em particular, cada nota deve ser emitida com apoio permanente, fato que faz com que o coralista amador aumente o seu nível de percepção em relação ao uso do diafragma. Desenvolver essa habilidade pode aumentar a consciência corporal do cantor iniciante, dando seqüência ao trabalho de construção da "postura corporal geral do coro" e da "consciência física da emissão sonora”.

Os dois primeiros exercícios vocais utilizados, digo dois, pois em um momento a sonoridade usada foi o bocca chiusa e em seguida a pronúncia de vogais com os homens e as mulheres cantando separados, foram os mesmos utilizados no ensaio anterior, fator que considero positivo, pois desta maneira o coro pode melhorar seu aprendizado a partir de conteúdos já conhecidos (qualidade de afinação dentro dos naipes - afinação das melodias, consciência auditiva do próprio som e memorização melódica), e a partir deles agregar novos conteúdos, advindos dos outros exercícios utilizados durante o ensaio.

Dentre os relatórios feitos durante os trabalhos de ensino/aprendizagem com os coros do Laboratório Coral Comunicantus, encontramos uma análise de Costa que diz o seguinte:

Para Piaget, as unidades estruturais básicas de pensamento e de ação dos indivíduos - os esquemas mentais - evoluem de estruturas mais simples para estruturas cada vez mais complexas, permitindo assim uma adaptação mais complexa e flexível à realidade (que vai se tornando cada vez mais diferenciada e abrangente) (PIAGET, 2001 apud COSTA, 2003, anexo 15). 
Neste sentido observo que o exercício seguinte, que utiliza um arpejo de escala maior até o quinto grau, já realizado no ensaio anterior, contribuiu para que se trabalhasse melhor a articulação das vogais, com a introdução de um novo texto, a palavra "praia”, que foi distribuída numa seqüência melódica já conhecida, agregando novos conteúdos a elementos musicais já conhecidos, mostrando a interligação entre a execução do vocalise que utiliza vogais para a melhor compreensão da técnica vocal e a execução de uma frase musical com texto, como comumente é encontrada nas peças musicais.

No quarto vocalise foi mantido o trabalho com as vogais, mas agora apenas com “i” e “o”, também com arpejo da escala maior, mas desta vez indo até o oitavo grau. O grupo realizou sem dificuldades devido à associação feita ao exercício anterior, e como o coro foi separado em dois naipes, graves e agudos, tornou-se possível trabalhar a extensão vocal de cada um deles, e isto fez com que o resultado fosse bastante positivo, principalmente com as vozes agudas, que conseguiram alcançar o seu melhor índice de qualidade vocal até aquele momento.

No último exercício Caiti trabalhou outro elemento novo que foi o arpejo com o sexto grau acrescentado, onde o coro apresentou uma necessidade de aprendizagem que já vinha ocorrendo há algum tempo, não conseguem cantar graus conjuntos com boa qualidade vocal. Será necessário construir com o grupo uma maneira para cantarem este tipo de intervalo, caracterizando a necessidade de aprendizagem para a realização do elemento "Correção e qualidade na realização dos fraseados da música”, onde ocorre um elemento melódico novo que é o sexto grau acrescentado.

Observando a descrição do aluno regente Renato há outra questão importante a ser trabalhada. Embora o coro venha crescendo semanalmente durante os exercícios de preparação vocal, tal fato parece não ocorrer na mesma proporção no ensaio coletivo. Pois os coralistas não estão conseguindo relacionar os conteúdos de aprendizagem dos exercícios vocais ao efetivamente cantarem as peças. Renato menciona que pediu para o grupo cantar um acorde de um trecho isolado da peça Ponta de Areia, mas o resultado foi inferior ao apresentado durante a execução da música. Acredito que ainda não havíamos chegado à estratégia correta para resolver tal questão, a solução poderia ser mais complexa do que abordar o trecho isoladamente, mas sim encontrar a origem do problema, fato que pode levar a resolução de outras necessidades. Creio que naquele momento seria preciso estabelecer uma referência de afinação para os coralistas, para que a partir dela pudessem orientar e apoiar seu aprendizado. Segundo Costa (2003, anexo 15) "O individuo herda a capacidade para a 
aprendizagem e o desempenho, mas a plena realização destas capacidades depende das condições que o meio ambiente irá oferecer”. Caberia a nós oferecer tais condições para amenizar a falta delas em seu cotidiano.

Desta maneira, nos perguntamos como o indivíduo pode cantar afinado se o conceito afinação não está claro para ele? Vejamos o que Sobreira (2003, p. 30) fala sobre isso: “O termo afinado será utilizado para designar pessoas que sejam capazes de reproduzir, vocalmente, as relações sonoras aceitas dentro dos padrões de nossa cultura”, partindo da premissa de que esta pesquisa trabalha este aspecto dentro do sistema tonal e modal temperados, não mencionando outros sistemas, e que esse é um dos elementos que compõem nosso referencial de análise, então é imprescindível desenvolver com o coro um parâmetro sonoro inicial de afinação baseados nestes sistemas.

As dificuldades de afinação não estão concentradas em apenas um trecho isolado de uma música, mas em diversos lugares de todas as peças trabalhadas neste momento por eles. Aponto como sugestão trabalhar no desenvolvimento de uma atividade pedagógica que possa solucionar esta questão a partir da abordagem dos seguintes elementos do referencial de análise adotado:

- Afinação das alturas

- Cantar intervalos melódicos ascendentes e descendentes;

- Memorização melódica;

- Correção e qualidade na realização dos fraseados da música;

- Qualidade de afinação dentro dos naipes - afinação das melodias;

- Qualidade de afinação entre os naipes - afinação das simultaneidades;

- Consciência física da emissão sonora (memória da tessitura);

- Consciência auditiva do próprio som;

- Consciência e compreensão melódica;

- Promover a prática do canto coral a 4 vozes e a habilidade para tanto. 
3.15. Avaliação de 13/05/2009

A avaliação do ensaio foi elaborada pela monitora Mariana Pilotto Reis que fez a seguinte descrição das atividades realizadas neste dia:

OBJETIVOS DO ENSAIO: Iniciar a leitura da peça Rodrigo Martinez, resolver as passagens que não estão tão boas na música Na Bahia Tem e a realização de uma atividade proposta pelo mestrando regente Paulo Lopes.

Foi um dos melhores ensaios que já tivemos! O nosso planejamento teve um bom foco, que foi a peça Na Bahia Tem. O mestrando regente Paulo desenvolveu uma atividade que foi ótima para o coro e resolveu um problema específico da música.

$\mathrm{O}$ ensaio começou com a aluna regente Caiti fazendo alongamento e em seguida exercícios de respiração com o coro. O vocalize começou com um exercício de bocca chiusa com o seguinte modelo melódico:

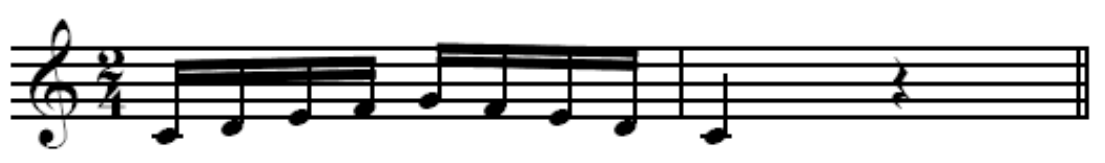

O segundo exercício foi feito com homens e mulheres separados e seguiu o mesmo modelo utilizado para o bocca chiusa, mas agora com as vogais "i u i", utilizando um "i” longo na primeira nota do exercício e em seguida realizando-o. Nesse mesmo exercício o professor Marco Antônio estava cantando no naipe dos baixos e pôde perceber as dificuldades de cada um do naipe, a presença do professor no vocalize foi de muita importância, pois é como discutimos em várias reuniões, os coralistas do Coral Oficina precisam muito de referências vocais para saber aonde estão e isso é importante lembrar, porque muitas vezes nós monitores não fazemos o aquecimento com os naipes.

O terceiro exercício (também separando homens e mulheres) foi com as sílabas "mo o ma o mo" e seguiu o modelo da tríade maior, como no exemplo abaixo:

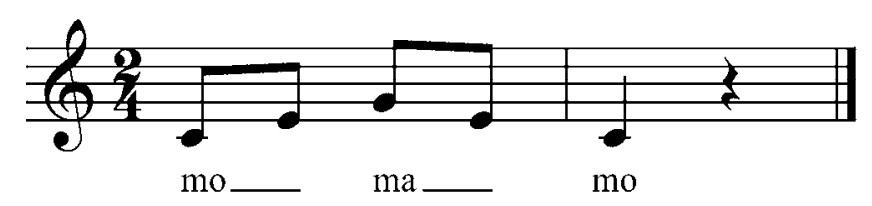

Nesse exercício a aluna regente Caiti chamou a atenção para a vogal "a" que estava sendo cantada muito "aberta" pelo coro em geral e pediu para que a cantassem na vertical, ou seja, abrindo a boca para cima e não para os lados. O Quarto exercício foi feito com as sílabas "pa pa pa” com a tríade maior, uma vez mais lenta e em seguida mais rápido, trabalhando assim a respiração do coro.No 
decorrer do exercício alguns coralistas,principalmente os homens, fizeram força ao invés de usar o apoio. O quinto exercício foi de arpejo de oitava com "i o" (do mi sol do\# sol mi do) e foram separados em vozes graves e agudas, alguns coralistas estavam produzindo o som do "o" muito aberto.

Em seguida seguimos para os ensaios de naipe da peça Na Bahia Tem. Eu fiz o ensaio das sopranos e seguimos bem, pois elas não têm muito problema com essa música então fizemos apenas uns ajustes nos contratempos (acho que agora sairão bem) e nas notas mais agudas. Tive o auxílio do professor Marco Antonio que me deu algumas dicas básicas de regência.

Após os ensaios de naipe tivemos a atividade ${ }^{32}$ desenvolvida pelo mestrando regente Paulo Lopes. A atividade consistia em som e sua representação gráfica, ele fazia um som com a voz, por vezes da mesma freqüência outras vezes um glissando para o agudo ou para o grave, e o coro deveria sugerir uma forma gráfica para cada som (resultado: linhas oscilantes, descendentes, ascendentes ou constantes). Em seguida Paulo Lopes cantou com os coralistas a escala de dó maior e perguntou o que poderia representá-la no gráfico, os coralistas sugeriram uma "escadinha”, o mestrando regente desenhou a escadinha na lousa e foi apontando cada parte da escada para ser vocalizada pelo coro, em seguida pediu que a mesma coisa fosse feita quase em staccato e em seguida inseriu no lugar a escala o trecho problemático da música $\mathrm{Na}$ Bahia Tem o qual o coro realizou sem o habitual vício do glissando no "tem, tem, tem".

Em seguida tivemos o ensaio geral das peças. O regente Rodrigo estava sem tempo para passar toca a música Na Bahia Tem, sendo assim selecionou um problema (que foi o trabalhado pelo mestrando regente Paulo) e passou em seguiu as três letras da peça sem a parte do "cantarolando". Foi um ensaio bem objetivo do regente e foi possível visualizar o resultado do trabalho feito pelo Paulo com a escolha do aluno regente Rodrigo. Após a música Na Bahia Tem começamos o trabalho com a nova peça Rodrigo Martinez. Essa foi uma peça escolhida justamente por ser de melodia fácil e optamos por fazer apenas a melodia principal para todo o coro, pois como estamos trabalhando peças a quatro vozes sentimos que estava faltando algo mais simples para o coral, algo com mais liberdade. Nesse primeiro ensaio tínhamos pouco tempo então ensinamos a melodia para o coro com a primeira letra. Houve um pouco de desatenção da parte dos monitores que não estavam muito firmes na finalização de uma frase da música, mas correu tudo bem.

Neste ensaio realizei uma atividade para trabalhar parâmetros de altura e afinação com o coro, conforme descreve Mariana em sua avaliação. Sua descrição mais detalhada bem como sua análise estão no sub-item 4.1.2.

\footnotetext{
${ }^{32}$ Esta atividade está descrita detalhadamente no subtitem 4.1.2.
} 
Análise do Ensaio:

A atividade de preparação e aquecimento vocal deste ensaio foi muito semelhante ao do ensaio do dia 22 de abril de $2009^{33}$, pois utilizou quase todos os exercícios realizados, com exceção do exercício com arpejo de escala maior com o sexto grau acrescentado, que escolhemos não utilizar nesta ocasião, mas os demais foram mantidos. A aluna regente Caiti trocou as vogais e as silabas utilizadas em determinados exercícios que contribuíram para o processo de ensino/aprendizagem dos conteúdos abordados. Os elementos do referencial trabalhados na preparação vocal deste dia foram:

- Postura corporal geral do coro;

- Consciência física da emissão sonora (memória da tessitura);

- Qualidade de afinação dentro dos naipes - afinação das melodias;

- Consciência auditiva do próprio som;

- Memorização melódica.

Neste ensaio foram trabalhados diversos parâmetros musicais como altura (exploração do grave e do agudo), duração, direcionalidade, freqüência, dentre outros, que possibilitaram que o coro desse um passo bastante importante na direção do desenvolvimento da escuta melódica consciente. O naipe de contraltos cantou de maneira afinada um determinado trecho da peça $\mathrm{Na}$ Bahia tem, o que ainda não havia acontecido e, além disso, conseguiu progressos muito importantes sobre a qualidade do seu som e afinação, possibilitado pelo trabalho de uma atividade pedagógica que utilizou os conhecimentos prévios dos coralistas, criando suas ZDP a partir de elementos gráficos. Outro aspecto positivo neste ensaio foi o início do aprendizado da peça Rodrigo Martinez, que visava o desenvolvimento de parâmetros de escuta, memória e execução melódica necessários ao desenvolvimento do coro naquele momento ${ }^{34}$. E a partir destas peças e exercícios foram trabalhados os seguintes elementos do referencial:

\footnotetext{
$\overline{{ }^{33} \text { Veja avaliação XIV do capítulo } 3 .}$

${ }^{34}$ Elementos já comentados no sub-item 2.3.13.
} 
- Afinação das alturas

- Cantar intervalos melódicos ascendentes e descendentes;

- Percepção e capacidade de emissão dos cromatismos;

- Postura corporal geral do coro;

- Consciência física da emissão sonora (memória da tessitura);

- Qualidade de afinação dentro dos naipes - afinação das melodias;

- Qualidade de afinação entre os naipes - afinação das simultaneidades;

- Consciência auditiva do próprio som;

- Memorização melódica;

- Percepção das outras vozes;

- Promover a prática do canto coral a 4 vozes e a habilidade para tanto.

Rodrigo Martinez foi a última peça a ser ensinada ao Coral Oficina Comunicantus no meu período de observação e atuação. Por este motivo optei por falar dela no âmbito do Repertório (subitem 2.3.13.), mais que das práticas pedagógicas analisadas no presente capítulo. É por isso também que, com esta avaliação encerro o processo de análise dos dados observados e das necessidades de aprendizagem melódicas apontadas por eles. 


\section{Desenvolvimento de atividades pedagógicas com objetivo de construir a escuta melódica (percepção auditiva):}

4.1. Apresentação de atividades pedagógicas desenvolvidas com o objetivo de construir determinados aspectos da percepção auditiva e da escuta melódica.

Este capítulo irá tratar sobre as atividades desenvolvidas a partir das observações que fizemos ao longo das aulas que participei na disciplina Práticas multidisciplinares em Canto Coral com estágio supervisionado, dos ensaios do Coral Oficina Comunicantus e das orientações que recebi dos professores Marco Antonio e Susana Igayara ao longo de um ano e meio de investigação dos aspectos pertinentes ao desenvolvimento da escuta melódica de coralistas integrados a coros vocacionais.

Nos sub-itens 4.1.1 e 4.1.2 estão descritas e analisadas duas das atividades que criei e realizei pessoalmente junto ao Coral Oficina Comunicantus.

No decorrer do item 4.2 estão descritas (e não analisadas) um grupo de atividades que foram pensadas durante meu período de trabalho (observação e ação) junto ao coro referido. No entanto, embora já não houvesse como aplicá-las eu mesmo, muitas delas foram oportunamente utilizadas posteriormente, sob supervisão dos professores responsáveis pelo Laboratório Coral. A opção por incluí-las no trabalho veio no sentido de mostrar um pouco mais o pensamento que orientou esta dissertação em sua vertente prática.

Por outro lado, pude tentá-las também eu mesmo à frente o Oficina Coral do Departamento de Música da Universidade Estadual de Maringá (UEM), onde sou professor temporário já que minha bolsa já que a minha bolsa que permitia minha viagem semanal a São Paulo havia chegado ao fim. Não trago aqui os resultados das aplicações em Maringá para não perder o foco do trabalho, mas, de comum acordo com meu orientador, foi feita a opção de expô-las neste trabalha enquanto as atividades possíveis na minha linha de pensamento, sem entrar na análise específica de cada uma delas. 
4.2. Atividade para trabalhar os aspectos: corporal e auditivo

Atividade trabalhada no ensaio de 01/04/2009 35

Esta atividade é descrita pela monitora Mariana Pilotto em sua avaliação. Optamos por descrevê-la mais detalhadamente por entendermos a importância que teve para o desenvolvimento do Coral Oficina Comunicantus naquele momento.

Um dos aspectos mais importantes no trabalho de desenvolvimento de um coro é a técnica vocal. Há várias discussões a respeito da maneira como deve ser abordada e que sugerem diversas alternativas, mas sem dúvida o trabalho focado na conscientização e no estímulo das habilidades vocais são os que apresentam resultados mais consistentes. Sobreira em seu livro A Desafinação Vocal, quando aborda a questão sobre a escolha dos exercícios vocais a serem trabalhados com os coralistas em ensaios sugere: "Estimulação a partir de técnicas que ajudem ao aluno a conhecer e ampliar suas possibilidades vocais” (SOBREIRA, 2003, p. 140).

Para promover tal estimulação decidimos utilizar uma atividade realizada no ensaio de 20/08/2008 ${ }^{36}$ abordando três aspectos em conjunto: o corporal, o auditivo e o vocal. O objetivo foi promover a prática do canto coral a duas vozes desenvolvendo habilidade de entoar notas longas contrastando com uma melodia com mais movimento rítmico. Para sua preparação utilizamos os mesmos exercícios de vocalise realizado dia 25 de março de $2009^{37}$, mas com um enfoque diferente, o controle da respiração diafragmática, assim interligando os aspectos supracitados.

Concluí a preparação me dirigi ao piano, toquei a nota Sol3 e cantei utilizando o fonema "la” como exemplo, a seguir, pedi aos homens para que fizessem o mesmo lembrando-os de usar a respiração diafragmática conforme havíamos feito no exercício de respiração no início do ensaio, depois também pedi que as mulheres cantassem e o resultado foram dois grupos bem afinados.

\footnotetext{
${ }^{35}$ Avaliação 3.12. do capítulo 3.

${ }^{36}$ Avaliação 3.6. do capítulo 3.

${ }^{37}$ Avaliação 3.11. do capítulo 3.
} 
Passei então para a segunda parte da atividade. Ensinei a seguinte seqüência melódica que pedi para cantarem também utilizando a silaba "la":

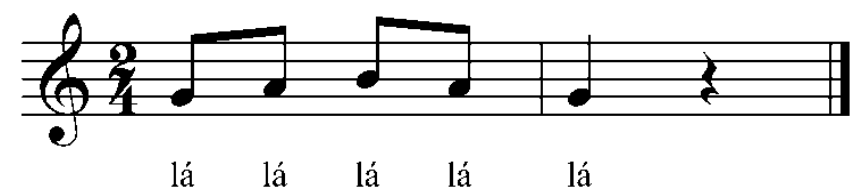

Em seguida repeti o procedimento anterior, ou seja, pedindo primeiro aos homens para cantar e depois as mulheres, e todos realizaram a tarefa sem dificuldades. Então propus o seguinte: que os homens cantariam o primeiro exemplo enquanto as mulheres cantariam o segundo exemplo simultaneamente, que foi realizado sem nenhuma dificuldade pelos dois naipes. Em seguida pedi a eles para trocarem os exemplos e as mulheres passaram a sustentar a nota parada e os homens a cantar a seqüência melódica, o que foi feito facilmente por eles.

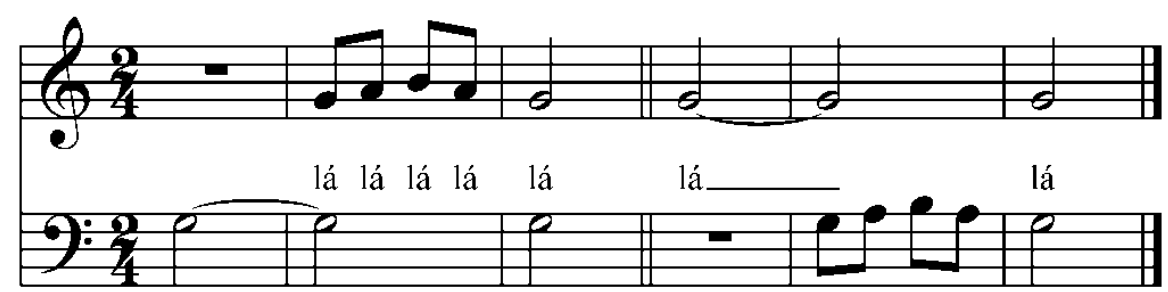

lá

lá

lá lá lá lá lá

Para concluir a atividade, pedi para eles repetirem o exercício, mas que trocassem de exemplo ininterruptamente, de forma que sempre enquanto um grupo estivesse cantando a nota parada o outro cantasse a seqüência melódica. Vejamos exemplo abaixo: 


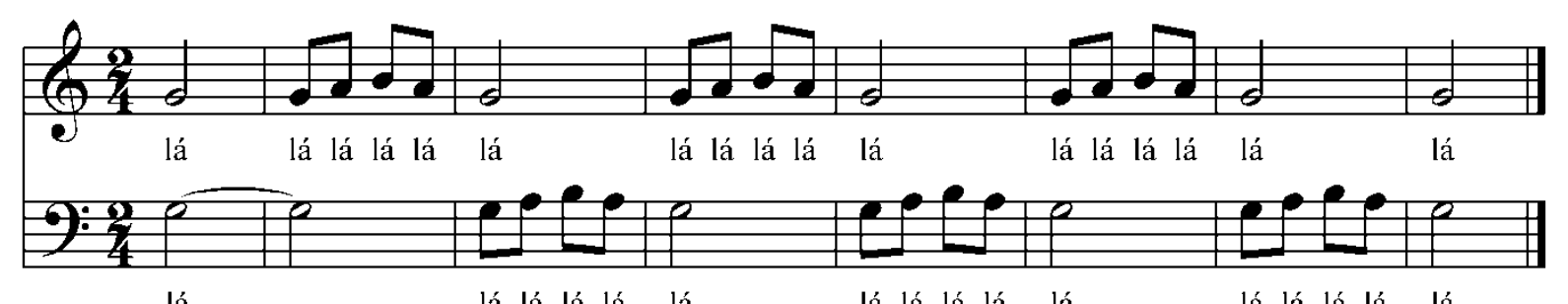

lá_

lá lá lá lá lá

lá lá lá lá lá

lá lá lá lá lá

Este exercício foi realizado algumas vezes e os dois naipes o desempenharam de maneira fluente, tranqüila e principalmente afinada, demonstrando que começavam a compreender o processo físico da respiração para o canto e da sustentação vocal e que começavam a perceber auditivamente o que estava acontecendo tanto no plano da afinação (com a nota longa), quanto no plano melódico (com a melodia executada alternadamente).

Dentro dos parâmetros definidos para a realização desta análise de procedimentos e conteúdos musicais, utilizamos os seguintes conteúdos para a elaboração desta atividade:

- Afinação das alturas;

- Consciência física da emissão sonora;

- Postura corporal geral do coro;

- Consciência auditiva do próprio som;

- Qualidade de afinação entre os naipes - afinação das simultaneidades;

- Percepção das outras vozes.

- Promover a prática do canto coral a 2 vozes e a habilidade para tanto.

Análise da atividade:

Na elaboração desta atividade avaliamos a necessidade de trabalhar alguns pontos que julgamos essenciais para sua realização, dentre os quais consideramos o elemento mais importante a necessidade deles "ligarem seus ouvidos" (já citada nesse trabalho), ou seja, estimularmos sua percepção auditiva para ouvirem os sons de forma consciente para servir como referência para o aprendizado de outros conteúdos. Observando a linha construtivista, nos aspectos relativos à aprendizagem vemos que "O fator mais importante que influi na 
aprendizagem é aquilo que o aluno já sabe” (AUSEBEL, NOVAK e HANESIAN, 1983, apud COLL et all, p. 66).

Considerando esse principio, planejamos esta atividade a partir da escolha de um aspecto do sonoro conhecido por todos e que facilitasse a identificação das melodias do exercício. Então escolhemos o timbre vocal como conteúdo para essa abordagem. Em seguida agimos do seguinte modo: no início da atividade separamos o coro em dois naipes, um masculino e outro feminino para facilitar a identificação de seus respectivos timbres, com o objetivo do som de um grupo não interferir no do outro. Aquele que cantava a nota parada ficava com sua atenção voltada para ouvir a melodia entoada pelo outro, procedimento que possibilitou o estímulo de uma escuta consciente e direcionada. Depois de a atividade ter sido executada algumas vezes os grupos já não se influenciavam mutuamente, pois o exercício levou-os a se acostumarem com suas diferenças timbrísticas sem serem influenciados pela melodia oposta.

4.3. Atividade para trabalhar a altura e afinação.

Atividade trabalhada no ensaio de 13/05/09 38

Quando iniciamos o trabalho junto ao Coral Oficina Comunicantus, os coralistas preencheram uma ficha de informações básicas (como de costume preenchem todos os candidatos a coralistas nos coros comunitários do laboratório) sobre sua formação geral e musical. Mesmo assim não podemos saber quais são as experiências vivenciadas por estas pessoas e nem mesmo que tipo de referências e conhecimentos prévios eles possuem sobre os diversos parâmetros musicais que são trabalhados no dia a dia do trabalho do coro.

(...) no caso dos conhecimentos prévios serem excessivamente desorganizados ou errôneos, e na medida em que avaliemos que estas características podem dificultar notavelmente os processos de ensino e aprendizagem dos novos conteúdos, é conveniente resolver esses problemas com atividades específicas destinadas a resolver essas questões, antes de iniciar o aprendizado de novos conteúdos. (MIRAS, 2004, p. 69)

\footnotetext{
${ }^{38}$ Avaliação 3.15. do capítulo 3.
} 
Nesta questão sobre a maneira como os conhecimentos estão organizados na mente dos alunos e a atuação do educador frente ao contexto de ensino/aprendizagem de conteúdos práticos, como são os musicais observamos que:

(...) devido à peculiar natureza social e cultural dos saberes que os alunos devem aprender, esse processo ativo não pode, na escola ${ }^{39}$, ser confiado ao acaso nem separar-se de uma ação externa, planejada e sistemática, que o oriente e guie na direção prevista pelas intenções educativas(...) (ONRUBIA, 2004, P. 123)

Partindo desses princípios surgiu a idéia de tentarmos ajudar os coralistas a organizar suas referências sobre o som de modo que obtivéssemos um conceito coletivo sobre o parâmetro altura. Quando ouvimos um som, formamos uma imagem mental sobre ele e transcrevê-la pode ajudar em sua compreensão e realização. Sendo assim, meu objetivo era levar o coralista a conseguir realizar um evento sonoro a partir do desenvolvimento de sua concepção pessoal do mesmo através de um elemento concreto ou visual de referência por ele definido. Desenvolvemos então uma atividade para trabalhar a altura dos sons com o Coral Oficina do Laboratório Coral Comunicantus. A atividade ocorreu da seguinte forma:

O objetivo era iniciar o desenvolvimento de um parâmetro coletivo de altura. Foi constatada neste grupo uma dificuldade de manutenção da altura e afinação em frases musicais descendentes, onde havia oscilações a cada vez que o coro cantava, principalmente o naipe de contraltos. O exercício foi elaborado a partir do pensamento de Jean Piaget, que aponta para o desenvolvimento do conceito a partir do signo. Desta forma, pensei em utilizar o que se chama em educação de “conhecimentos prévios” dos coralistas para poder, a partir deste conhecimento, levá-los à construção de uma referência inicial, até chegar a um padrão sonoro de altura e afinação coletivo.

Inicialmente expliquei a atividade que iríamos realizar, abordei os conceitos de senso comum do que são os sons graves e agudos, em seguida cantei dois sons na mesma freqüência: um longo e o outro curto. Então perguntamos ao grupo o seguinte: baseado na imagem mental que cada um tem do som que ouviu, como vocês representariam graficamente os sons que acabaram de ouvir? A resposta na maioria dos casos foi a de uma linha reta maior para o som longo e uma menor para o som curto, que escrevi em um quadro à frente do coro.

\footnotetext{
${ }^{39}$ No coro no nosso caso.
} 
Em seguida, fiz um som em glissando descendente e perguntei: E este som? Como vocês representariam graficamente? O grupo em sua maioria indicou uma linha diagonal descendente, e que também coloquei no quadro. Fiz então outro som glissando só que agora ascendente, e o grupo indicou uma linha diagonal ascendente que eu anotei no quadro. A partir daí mostrei alguns exemplos combinando os sons representados no quadro e perguntava sempre qual seria a imagem que eles utilizariam, e suas respostas sempre utilizavam as imagens que havíamos estabelecido no início da atividade. Então, a partir deste jogo, o coro estabeleceu uma padronização de imagens, ou seja, símbolos para representar estes quatro tipos de som.

Num segundo momento, pedi ao aluno regente Filipe dos Santos para tocar ao piano uma escala maior do $1^{\circ}$ ao $5^{\circ}$ graus (ascendente) de forma pausada para que todos pudessem perceber as diferenças de altura entre as notas. Em seguida pedi ao grupo que representasse graficamente os sons que tinham acabado de ouvir. A sugestão geral foi a de uma escada com seus degraus no sentido ascendente, que coloquei no quadro, e depois pedi para o coro cantar as notas com o apoio do piano e comigo apontando a mudança dos degraus no quadro. Depois pedi ao Filipe para tocar a mesma escala em movimento descendente, e o grupo me indicou para escrever uma escada com degraus no sentido descendente, e em seguida repeti o procedimento citado acima.

Em uma nova etapa, utilizei dois trechos da peça "Na Bahia tem”, que era onde estavam aparecendo os maiores problemas:

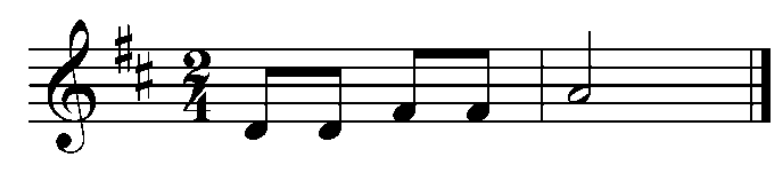

Pedi ao monitor para tocar a seqüência ao piano e em seguida ao coro que cantasse apoiados pelo instrumento, a vogal escolhida foi o "É”, o grupo cantou com facilidade e demonstrando uma boa afinação. Logo após, pedi ao monitor para tocar uma segunda seqüência de notas, mas agora descendente: 


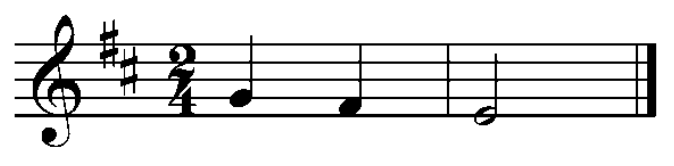

Agi da mesma maneira pedindo para cantarem com a vogal “É” obtendo novamente uma boa afinação. Na continuação pedi aos homens para cantar a primeira seqüência, e as mulheres para responderem cantando a segunda, ainda utilizando a mesma vogal, o resultado foi muito bom, os dois naipes, masculino e feminino, cantaram as suas seqüências sem confundir as alturas, tanto no sentido ascendente quanto no descendente, fato que não havia acontecido nos ensaios anteriores. Então, para completar a atividade pedi aos grupos (homens e mulheres) para repetirem o trecho, mas agora com a letra original da música, que na primeira frase é “Na Bahia tem”, e na segunda “Tem, tem, tem”, e o resultado se repetiu, ou seja, o grupo conseguiu cantar o trecho que havia problemas na realização das alturas anteriormente, agora com os intervalos corretos e sem os problemas (glissandos involuntários e uma má colocação vocal) que estavam ocorrendo. Considero que a atividade teve seus objetivos alcançados, pois buscamos melhorar a emissão sonora do coro a partir da conscientização e da criação de um parâmetro coletivo de sons específicos, de maneira que não cantassem de forma instável com relação à sustentação e manutenção de uma nota longa ou na mudança de uma nota para outra, ou ainda uma seqüência delas, principalmente nas frases descendentes.

Análise da atividade:

Esta atividade serviu para começar a desenvolver com o coral uma referência coletiva de altura. O procedimento utilizado buscou estabelecer um parâmetro a partir de uma imagem despertada na mente das pessoas pelos sons utilizados na atividade. O fato da maioria das pessoas optarem por uma linha reta para representar o som longo (de maior duração e altura constante), que foi o primeiro exemplo sonoro utilizado, aponta para uma imagem, por alguma razão já existente em seu back ground, que foi associada ao som após a minha pergunta, pois foi ela que fez com que eles procurassem uma imagem (figura concreta/visual) em suas mentes que seria, em suas concepções, o mais próximo do que ouviram 
(abstrato/invisível). Em seguida dei o exemplo cantando um som mais curto (breve, mas de mesma altura), e apoiados em um parâmetro previamente estabelecido (no caso a linha reta) optaram por representá-lo por um traço curto. Desta forma, podemos perceber que um som de mesma altura passou a ser um elemento concreto, pois, a partir de sua audição, as pessoas começaram a identificá-lo e até a classificá-lo, o que tornou mais fácil e natural realizar a seqüência do trabalho, já que fora estabelecido um "ponto de apoio" que a cada exemplo novo referendava a compreensão do novo parâmetro definido a partir do novo som ouvido, ou seja, estabeleceu-se uma ZDP.

Para continuar o trabalho com alturas, utilizei uma escala maior do primeiro ao quinto grau, pelo fato dos coralistas poderem perceber as diferenças intervalares e o sentido que seguiam (inicialmente do grave para o agudo). Pedi ao pianista para tocar as notas separadamente, ou seja, com pausas entre si para desta forma ficar mais evidente a mudança dos sons. Os coralistas foram unânimes em dizer que o sentido era o ascendente, não houve dúvidas. A partir dos sons com glissandos usados na atividade momentos antes, começou a ficar claro para eles a diferença entre um som que caminha para o grave e outro que caminha para o agudo. Da mesma maneira, quando pedi ao pianista para tocar a escala no sentido descendente (do quinto para o primeiro grau), o grupo não hesitou e imediatamente identificou com uma seqüência de sons descendentes. $\mathrm{O}$ fato de terem conseguido identificar estas diferenças entre os sons, fez com que eles conseguissem cantar com segurança a escala nos dois sentidos, ancorados na referência que agora tinham.

Após estabelecer com o coro o parâmetro altura com diferenças mais próximas, no caso, por graus conjuntos, então o próximo passo para trabalhar a necessidade de aprendizagem que o coro demonstrava ao cantar os intervalos descendentes, foi colocá-los a cantar o trecho da música que estavam com dificuldades, mas com um artifício pedagógico: sem eles saberem que era o dito trecho. Por isso criei o exercício com as mesmas notas da música que eles não conseguiam cantar, mas utilizando uma vogal e apenas brincando com os sons. O grupo realizou a atividade com extrema facilidade e, quando finalmente coloquei o texto da música, o grupo então percebeu o que havia acontecido: estavam cantando aquele trecho tão "difícil” até aquele momento, porém sem nenhuma dificuldade e com desenvoltura. Pude então perceber em suas feições a expressão de alegria que tiveram por vencer a dificuldade que se lhes apresentava. Venceram pela compreensão de parâmetros até então desconhecidos, ou melhor, desorganizados em suas mentes, e agora acessíveis ao seu pensamento e à sua compreensão, e não pela repetição exaustiva.

Desta maneira forma trabalhamos nesta atividade os seguintes elementos do referencial: 
- Afinação das alturas;

- Cantar intervalos melódicos ascendentes e descendentes;

- Percepção e capacidade de emissão dos cromatismos;

- Memorização melódica;

- Correção e qualidade na realização dos fraseados da música;

- Qualidade de afinação dentro dos naipes - afinação das melodias;

- Consciência física da emissão sonora

- Postura corporal geral do coro;

- Consciência auditiva do próprio som;

- Consciência e compreensão melódica;

O aprendizado da altura não se resume apenas nesta breve atividade que desenvolvemos para ajudar a solucionar um problema específico. Ela demanda uma seqüência de planejamentos e atividades para os coralistas continuarem seu processo de desenvolvimento musical. Já dissemos que não é objetivo deste trabalho abordar todas as questões sobre o parâmetro da altura, mas sim desenvolver os conteúdos relativos ao desenvolvimento do ouvido melódico do coralista vocacional. 


\section{CONCLUSÃO}

\section{Dificuldades apresentadas pelos coralistas durante os ensaios:}

“O planejamento de qualquer ação pedagógica deve se nortear pelas características, pelos conhecimentos prévios e pelas potencialidades do grupo com o qual se vai trabalhar" (COSTA, 2005, p. 6).

Durante todo o período em que participei dos ensaios, aulas e demais eventos como monitor e aluno regente integrado ao Comunicantus: Laboratório Coral, bem como o período em que desenvolvemos a presente dissertação, uma de suas principais diretrizes na esfera pedagógica sempre foi a escolha dos conteúdos musicais que seriam utilizados junto aos coros, tais como os utilizados nos exercícios de aquecimento e preparação vocal, de respiração, de trabalho com o repertório, procedimentos de ensino/aprendizagem, dentre outros, sempre selecionados mediante a consideração do nível musical momentâneo dos coralistas, as suas necessidades de aprendizagem que se configuravam e pelos desafios que seriam importantes para o seguimento do trabalho. Segundo Solé (2004, p. 53):

Partir daquilo que o aluno possui, potencializá-lo e conotá-lo positivamente é o sinal de respeito por sua contribuição, o que, sem dúvida, favorece sua auto-estima. Colocar desafios a seu alcance, observar uma distancia ótima entre o que traz e o que lhe colocado incentivam seu interesse e lhe permitem confiar em suas próprias possibilidades; proporcionar-lhe as ajudas necessárias possibilita forjar uma imagem positiva e ajustada.

Tais conceitos foram postos em prática ao longo de nossa investigação, pois realizar uma abordagem que favoreça a auto-estima de quem está participando de um processo de ensino/aprendizagem, pode conduzir a obtenção de melhores resultados. Dessa maneira, as necessidades de aprendizagem apresentadas pelos coralistas do Coral Oficina Comunicantus, juntamente com seus conhecimentos sobre os conteúdos musicais foram os norteadores de nosso trabalho. A relevância destes dois aspectos foi o que determinou todo o caminho a ser trilhado, assim como todas as escolhas em relação a cada ponto abordado e desenvolvido nos ensaios. 
Trabalhamos de maneira a estabelecer, paulatinamente com os coralistas, os conteúdos abordados necessários ao desenvolvimento de sua escuta melódica, ponto pelo qual buscamos melhor qualidade da afinação individual e coletiva do coro, para alcançarmos um resultado mais satisfatório durante as performances do grupo, tanto nos ensaios quando nas apresentações públicas de que participou. O referencial de análise que utilizamos propiciou que fossemos percebendo quais os aspectos freqüênciais e melódicos mais importantes a serem trabalhados em cada momento, dirigindo nossas ponderações acerca dos resultados demonstrados pelo grupo, levando-nos as escolhas que consideramos mais adequadas, para optarmos pelos caminhos didáticos adotados. Segundo Martins (1985, p. 19): “A aprendizagem musical começa com percepções e destas percepções são formados os conceitos que embasam o pensamento musical. Há uma relação de dependência entre percepção e formação de conceito”. Este pensamento explica muito sobre nossa atuação, pois procuramos desenvolver a escuta melódica dos coralistas tratando dos diversos conteúdos inerentes ao campo da percepção auditiva, com o intento de que eles fossem estabelecidos através das experiências nos ensaios, onde as relações fossem compreendidas através de sua realização prática.

O referencial de análise que utilizamos, embora aborde outras questões que não somente da escuta melódica, funcionou como guia para encontrar os questionamentos somente sobre os elementos (colhidos em nossas observações) que deveriam importar para tal demanda, deixando mais clara a escolha das intervenções e ajudas aos coralistas. Segundo a linha da área de Educação conhecida como construção do conhecimento, “o conteúdo de aprendizagem também ajuda a matizar e de certo modo determina a pertinência dos instrumentos que podem ser utilizados” (COLL et al, 1992, apud MIRAS, 2004, p. 74), dessa maneira vemos que o referencial adotado pôde nos amparar nos dois aspectos, pois em um processo observatório é preciso considerar que: “Em todo caso, em termos gerais, é conveniente que, seja qual for o instrumento de exploração utilizado, tentemos norteá-lo da forma mais clara possível no processo de ensino e aprendizagem com o qual está relacionado” (MIRAS, 2004, p. 74), relação esta que ficou comprovada mediante as interligações entre a detecção das necessidades de aprendizagem, os elementos que deveriam ser abordados para atingi-las e os procedimentos que poderiam ser utilizados para solucionálas. 


\section{Conclusões sobre os resultados pesquisados.}

Os resultados obtidos em nosso trabalho estão muito distantes de uma solução definitiva, pois os processos que abrangem o desenvolvimento da escuta melódica dos integrantes de um coral estão em constante modificação, são sempre móveis e a cada período surgem novas necessidades de aprendizagem. “O domínio da maior parte dos conteúdos de aprendizagem nunca pode ser considerado definitivo (...), estes conteúdos são desenvolvidos progressivamente e sempre podem ser ampliados” (COSTA, 2005, p. 146).

Atingir um elevado nível de afinação com coralistas integrados ao Coral Oficina Comunicantus não era o foco principal que almejávamos ao final deste trabalho, mas sim compreender os processos pelos quais esta evolução pudesse ser alcançada a partir do desenvolvimento de sua escuta melódica. Percebemos que para desenvolver as habilidades das pessoas nesse campo, é necessário utilizar o que elas têm de conhecimento sobre tais aspectos, para levá-los a sua utilização consciente, pois entendemos que esta é uma referência bastante sólida com a qual podemos abordar outros pontos interligados à aprendizagem musical e que devem ser estimulados para a continuidade de seu crescimento.

As atividades elaboradas ao longo desse período tiveram seu planejamento realizado com este pensamento onde, segundo Costa (2005, p. 148):

\footnotetext{
Seus objetivos agregam também a preocupação com a formação do coralista, isto porque propõe exatamente a vivência prática destes conteúdos. Ou seja, Como servem para a avaliação do grau de conhecimento de conteúdos da área coral, estas atividades propostas são apropriadas também para treinar habilidades e para elucidar conceitos musicais.
}

Nesse sentido pontuamos que tais procedimentos buscaram suscitar nos coralistas a realização consciente dos conteúdos musicais, mudando assim sua percepção de todas as questões envolvidas através do fazer musical, o que gerou maiores envolvimento e compreensão do grupo em relação aos aspectos trabalhados e, tendo como conseqüência um resultado de performance mais satisfatório.

Desta forma concluímos que desenvolver a escuta melódica consciente com o coro é um caminho que pode ajudar a sanar diversas necessidades de aprendizagem, melhorando a 
cada ensaio seus resultados com relação aos aspectos inerentes ao canto coral e, que a melhoria de habilidades como afinação, consciência melódica, consciência do próprio som e de todos os outros apontados pelo referencial, podem ser melhorados em conseqüência desse tipo de procedimento pedagógico, pois todos os conteúdos estão interligados. Levar os coralistas a se familiarizarem com tais particularidades pode propiciar um resultado geral de performance com um nível bastante elevado, especialmente se considerarmos um coro vocacional, cuja a característica principal é, a nosso ver, a de um "Fazer Educativo" (Informação Verbal) ${ }^{40}$.

\footnotetext{
${ }^{40}$ RAMOS, Marco A. da S. Comentário de aula da disciplina Práticas multidisciplinares em canto coral com estágio supervisionado da USP, São Paulo, abr, 2010.
} 


\section{Referências Bibliográficas}

AMARAL, Kleide F. Pesquisa em Música e Educação. São Paulo: Edições Loyola, 1991. 119p.

BRÜNNER, Milagro. Formación de coros escolares. La Revista Eufonía: Didáctica de la Música. Barcelona: Editora Liberdúplex, 2009. 128 p.

CANONICE, Bruhmer C. F. Normas e padrões para elaboração de trabalhos acadêmicos. 2. ed. Maringá: Eduem, 2009. 65 p.

COLL, César, et. al. O construtivismo na sala de aula. 6. ed. São Paulo: Ática, 2003. 221 p.

COSTA, Paulo R. M. Diagnose em Canto Coral: parâmetros para análise e ferramentas para a avaliação. 2005. 169 f + anexos. Dissertação (Mestrado), CMU/ECA/USP. São Paulo.

CROWTHER, Duane S. Teaching Choral Concepts. Bountiful : Horizon Publishers, 1981.

DRAHAN, Snizhana Ouvir a voz: a percepção da produção vocal pelo regente coral : método e formação. 2007. 146 p. Dissertação (Mestrado) - ECA/USP/CMU. São Paulo.

FRANCO, Maria Amélia S. Pedagogia da Pesquisa-Ação. Educação e Pesquisa, São Paulo, v. 31, n. 3, p. 483-502, set/dez 2005.

IGAYARA, Susana C. Descrição do trabalho Coral do Museu Lasar Segall. São Paulo: Museu Lasar Segall, 1990.

IGAYARA, Susana C. Material didático da disciplina Repertório Coral: ECA/USP, 2003. s p.

IGAYARA, Susana C. Relatório de atividades de pesquisa. São Paulo: ECA/USP, 2006.

ISAACS, Alan. Entonação. In: MARTIN, Elisabeth. Dicionário da Música. Rio de Janeiro: Jorge Zahar Editor, 1985. 911 p.

MARTINS, Raimundo.Educação musical: conceitos e preconceitos. Rio de Janeiro: Funarte, 1985. $49 \mathrm{p}$.

RAMOS, M. A. da Silva. Canto Coral: do repertório temático à construção do programa. 1988. 3 v., il. Dissertação (Mestrado). CMU CBD/ECA/USP. São Paulo.

RAMOS, M. A. da Silva. O ensino da regência coral. 2003. 107 f + anexos: il. Tese (Livre Docência). CMU/ECA/USP. São Paulo.

SADIE, Stanley. Entonação, freqüência, altura, quodlibet, ostinato. In: LATHAN, Alison. Dicionário Grove da Música: Edição Concisa. Rio de Janeiro: Jorge Zahar Editor, 1994. 1048 p.

SCHAFER, R. Murray. O ouvido pensante. São Paulo: UNESP, 1991. 339 p. 
SCHOENBERG, Arnold. Fundamentos da Composição Musical. São Paulo: EDUSP, 2008. $272 \mathrm{p}$.

SOBREIRA, Silvia Garcia. Desafinação Vocal. Rio de Janeiro: Musimed Edições Musicais, 2003.

SUZIGAN, Geraldo O.; SUZIGAN, Maria L. C. Educação Musical: Um fator preponderante na construção do ser. São Paulo: CLR Baliero, 1986. 44 p. : il

VILLA-LOBOS, Heitor. Programa do ensino de música. Rio de Janeiro: Secretaria Geral de Educação e Cultura, 1937a.

. O ensino popular de música no Brasil: o ensino da música e do canto orfeônico nas escolas. Rio de Janeiro: Secretaria Geral de Educação e Cultura, 1937b. 1946. Educação Musical. Boletim Latino Americano de Música, Montevidéu, p. 495-588,

A Educação Artística no Civismo. Presença de Villa-Lobos. Rio de Janeiro: MEC/Museu Villa-Lobos, v. 5, p. 81-87, 1970.

ZABALA, Antoni. A Prática Educativa. Porto Alegre: Artes Médicas, 1988.

\section{Bibliografia Consultada}

ABEM, 2001.TUREK, Ralph. The Elements of Music: Concepts and Applications v. 1. 2. ed. New York: Music-Book Associates, 1996.

ABROMONT, Claude MOTALEMBERT, Eugene de. Teoria de la Musica: Um Guia. México: Fondo de Cultura Econômica, 2005. 622 p.

ÁVILA, Marli B. O método Kodály como instrumento de musicalização no contexto educacional brasileiro. 1993. 312p. Dissertação (Mestrado), ECA/USP - CAP. São Paulo.

CHOSKY, Lois. The Kodály Method: comprehensive music education from infant to adult. 2. ed. Englewood Clifs: Prentice-Hall, 1998. 255 p.

GARRETSON, Robert L. Conducting Choral Music.7. ed. New Jersey: Prentice-Hall, 1993.

MED, Bohumil. Teoria da Música. 4ª Ed. rev. e ampl. Brasília: Musimed, 1996.

MUSEU LASAR SEGALL.Relatório de 1992: Históricos, análises, perspectivas. São Paulo, 1992.

HINDEMITH, Paul. Treinamento elementar para músicos. São Paulo: Ricordi Brasileira, 1975. 
KODAMA, Marcia Kazue. Tocando com Concentração e Emoção: A Psicologia e a Neurofisiologia ajudando o intérprete. São Paulo: Editora Som, 2008.

PIAGET, Jean. A formação do símbolo na criança. Rio de Janeiro: Guanabara - Koogan.

SALLES, Pedro Paulo. A gênese da notação musical na criança. Dissertação (Mestrado) Faculdade de Educação/USP. São Paulo, 1996.

SCHAFER, R. Murray. A afinação do mundo. São Paulo: UNESP, 1997. 382 p.

SCHOPENHAUER, Arthur. A arte de escrever. Porto Alegre: L\&PM Editores, 2007.

SOUZA, Jusamara. A concepção de Villa-Lobos sobre a Educação Musical. Revista Brasiliana. Rio de Janeiro, n. 3, p.18-25, set. 1999.SOUZA, Jusamara. Contribuições teóricas e metodológicas da Sociologia para a pesquisa em Educação Musical. In: ENCONTRO ANUAL DA ASSOCIAÇÃO BRASILEIRA DE EDUCAÇÃO MUSICAL, 5., 1996, Londrina. Anais... Londrina: ABEM, 1996. p.1-39.SOUZA, Jusamara et al. Música, Cotidiano e Educação. Porto Alegre: Universidade Federal Do Rio Grande Do Sul, 2000.

SOUZA, Jusamara. Múltiplos espaços e novas demandas profissionais: reconfigurando o campo da Educação Musical. In: $X$ ENCONTRO ANUAL DA ASSOCIAÇÃO BRASILEIRA DE EDUCAÇÃO MUSICAL, 10, 2001, Uberlandia. Anais... Uberlândia:

SOUZA, Jusamara et al. Cotidiano e Mídia: desafios para uma Educação Musical Contemporânea. In: Música, Cotidiano e Educação. Porto Alegre: Universidade Federal Do Rio Grande Do Sul, 2000

SWANWICK, Keith. Ensinando música musicalmente. São Paulo: Moderna, 2003

SZÖNYI, Erzsébet. A Educação Musical na Hungria através do Método Kodaly. São Paulo: Sociedade Kodaly do Brasil, 1996

VIGOTSKY, Liev Semiónovitch. A formação Social da Mente. São Paulo: Martins Fontes, 1996.

VIGOTSKII, Lev S.; LURIA, Alexander R.; LEONTIEV, Alexis N. Linguagem, desenvolvimento e aprendizagem. 7.ed. São Paulo: Ícone, 2001. 228p.

WARNER, Brigitte: Orff-Schulwerk: Applications for the Classroom, Prentice-Hall, 1991.

WILLEMS, Edgard. Guia Didático para el Maestro. Buenos Aires: Editora Universitária, 1978.

WILLEMS, Edgard. Las Bases Psicológicas da la Educación Musical. Buenos Aires: Editora Universitária, 1969.

WILLEMS, Edgard. L’oreille Musicale - Tome II. Viena : Editora Pro Musica, 1972. 


\section{SITES PESQUISADOS}

http://www.abemeducacaomusical.org.br/

http://comunicantus.blogspot.com/

http://michaelis.uol.com.br/moderno/portugues/index.php?lingua=portuguesportugues\&palavra=afinação

http://alldownunder.com/oz-u/songs/kookaburra-song-9.htm

http://www.priberam.pt/dlpo/p://www.musicahodie.mus.br/9_2/92_06.pdf

http://www.scielo.br/pdf/\%0D/ep/v31n3/a11v31n3.pdf

http://ceie-sbc.educacao.ws/pub/index.php/sbie/article/view/130 
APÊNDICE 


\section{Apêndice}

1. Outras Atividades desenvolvidas.

Todas as atividades que descrevo a seguir foram elaboradas para estimular o desenvolvimento da escuta melódica, embora não sido utilizadas ao longo do processo do desenvolvimento desta investigação realizada com o Coral Oficina Comunicantus, foram desenvolvidas a partir das necessidades de aprendizagem demonstradas ao longo de três semestres de ensaios.

1.1. Atividade para trabalhar percepção auditiva e vocal

Objetivo:

Estimular o desenvolvimento dos seguintes pontos do referencial:

- Afinação das alturas;

- Consciência física da emissão sonora

- Consciência auditiva do próprio som

Passos de realização da atividade sugerida:

- Pedir ao coro para cantar um glissando descendente;

- Pedir ao coro para cantar um glissando ascendente;

- Pedir ao coro para executar glissandos descendentes e ascendentes (senóide melódica);

- Realizar os glissandos novamente fazendo o coro parar sustentando as notas hora na região de tessitura aguda, hora na grave;

- Repetir o procedimento anterior, fazendo o coro sustentar notas na região de tessitura média. 
1.2. Atividade para trabalhar afinação de intervalos.

Objetivos:

Trabalhar a afinação de duas notas para estabelecer uma referência inicial de afinação, estimulando o desenvolvimento dos seguintes pontos do referencial:

- Afinação da alturas;

- Cantar intervalos melódicos ascendentes e descendentes;

- Consciência física da emissão sonora (memória da tessitura);

- Postura corporal geral do coro;

- Consciência auditiva do próprio som;

- Consciência e compreensão melódica;

- Percepção das outras vozes.

- Pedir para o coro ouvir as notas Dó e Ré tocadas pelo piano;

- Cantá-las (com nome de nota juntamente com o coro várias vezes;

- Pedir aos coralistas para formarem um círculo para cantarem da seguinte forma:

O cantor a minha frente cantará a nota Dó e o coralista a seu lado a nota Ré. O próximo tornará a cantar a nota Dó e assim sucessivamente até passar por todos terem e cantado as duas notas;

- Se alguém do grupo não conseguir cantar corretamente, pedir para algum coralista voluntário cantar junto com ele quando chegar sua vez para ajudá-lo;

- Manter depois o procedimento, mas com a ordem indicada pelo regente, ou seja: o primeiro que ele indicar cantará a nota Dó, o segundo Ré, o terceiro Dó e assim seguindo aleatoriamente até todos terem participado diversas vezes.

Obs.: Podem-se acrescentar mais notas gradativamente. 
1.3. Atividade com intervalos melódicos

Objetivos:

Esta atividade tem como foco principal estabelecer uma referência sonora com os coralistas. Escolhemos o intervalo de terça menor (notas sol e mi) para realizar essa tarefa que

- Cantar o intervalo de terça menor descendente (com nome de nota) apoiado pelo piano e depois pedir para o coro repetir.

-Cantar diversas combinações deste intervalo modificando o ritmo, como no exemplo abaixo:

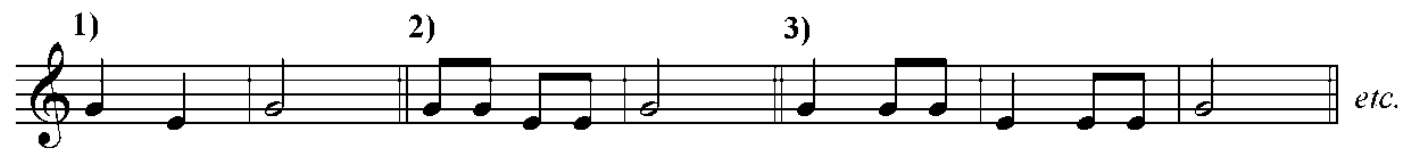

- Escolher aleatoriamente pessoas dentro do coro para repetir as frases melódicas individualmente.

- Substituir o nome das notas por palavras

- Dividir o coro em dois grupos para trabalhar o procedimento de pergunta e resposta entre eles cantando as frases inteiras;

- Dividir as melodias entre eles, deixando cada grupo responsável por uma nota, para que cada um deles cante sempre na mesma altura.

- Inverter as notas entre os grupos. 
Através deste procedimento poderemos trabalhar com os coralistas os seguintes ietns do referencial:

- Afinação das alturas;

- Cantar intervalos melódicos ascendentes e descendentes;

- Consciência física da emissão sonora (memória da tessitura);

- Fraseado;

- Manutenção da afinação ao longo da peça;

- Postura corporal geral do coro;

- Consciência auditiva do próprio som;

- Consciência e compreensão melódica;

- Memorização melódica;

- Percepção das outras vozes.

1.4. Atividade com intervalos melódicos

A partir da atividade anterior a questão agora é continuar estabelecendo referências sonoras apoiadas nas notas musicais, principalmente por causa do treinamento dentro do sistema tonal, sendo assim, vamos acrescentar mais uma nota às ensinadas e também um intervalo, a segunda maior, para ampliar as possibilidades de combinações melódicas e estimular a habilidade de entoação do grupo. Sugerimos proceder da seguinte maneira:

- Cantar com o apoio do piano as notas sol e mi (com nome de nota), como na atividade anterior;

- Cantar várias combinações rítmicas com as notas sol e lá como no exemplo abaixo: 


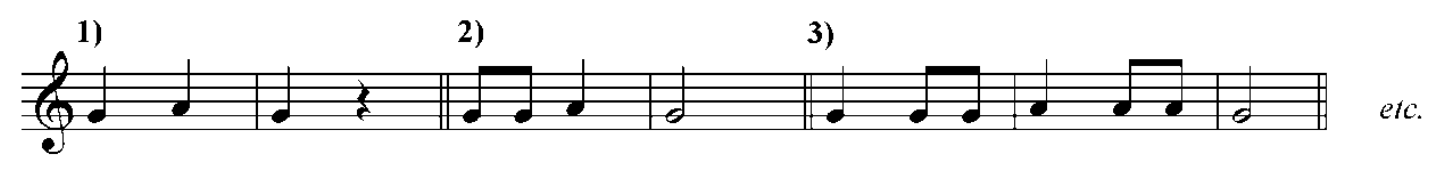

- Combinar com as notas da atividade anterior:

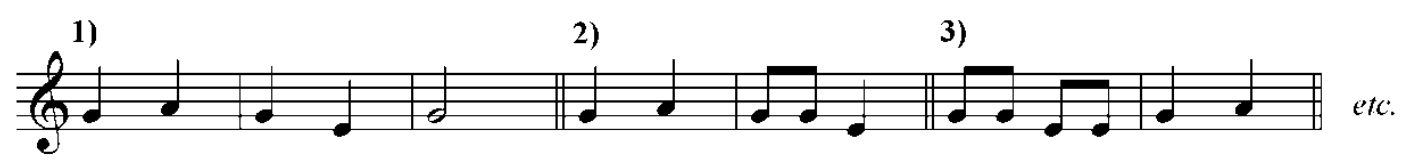

- Dividir o coro em dois grupos para brincar de pergunta e resposta com os dois exemplos melódicos:

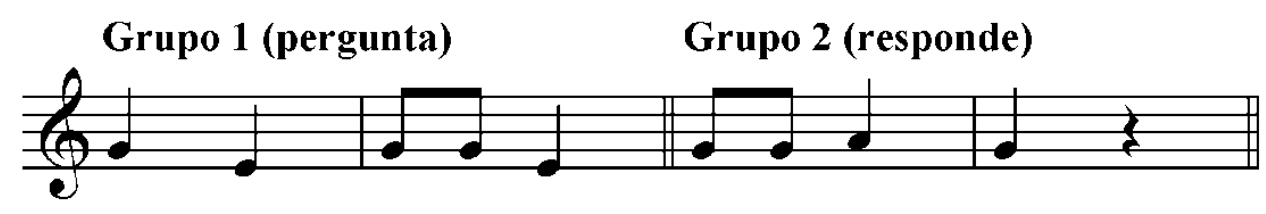

-Inverter as melodias entre os grupos

- Criar um texto para cada melodia e ensine a eles.

Obs: sugerimos montar a peça A galinha do vizinho de Marli Ávila pode reforçar o aprendizado.

Através deste procedimento poderemos trabalhar com os coralistas os seguintes pontos do referencial:

- Afinação das alturas;

- Cantar intervalos melódicos ascendentes e descendentes;

- Consciência física da emissão sonora (memória da tessitura);

- Fraseado;

- Memorização melódica; 
- Manutenção da afinação ao longo da peça;

- Postura corporal geral do coro;

- Consciência auditiva do próprio som;

- Consciência e compreensão melódica;

- Percepção das outras vozes.

- Qualidade de afinação dentro dos naipes - afinação das melodias;

- Qualidade de afinação entre os naipes - afinação das simultaneidades.

1.5. Atividade com notas iguais e repetidas

Objetivos:

Desenvolver referências sonoras com os coralistas para obter melhor qualidade de escuta melódica e afinação.

Utilizamos nesta atividade elementos gráficos para construir imagens sonoras coletivas para o trabalho de desenvolvimento da escuta melódica, norteados por dados já conhecidos advindos de outra área de conhecimento. Vejamos: “(...) o ensino como ajuda ajustada sempre pretende, a partir da realização, compartilhada ou apoiada, de tarefas, incrementar a capacidade de compreensão e atuação autônoma ${ }^{41}$ do aluno." (ONRUBIA, 2003, 126 p.)

Este procedimento de ajuda ajustada busca possibilitar ao coralista a utilização de referências que já possui para ampará-lo na realização e compreensão de um novo conteúdo que será abordado, com o objetivo de executá-lo através da relação estabelecida entre o que já sabe e o que está aprendendo.

\footnotetext{
${ }^{41}$ Destaque em itálico do autor.
} 
Esta forma de atuação do regente, onde ele auxilia seus coralistas no aprendizado de conteúdos musicais, pode levá-los a resultados bastante sólidos. Segundo a linha construtivista de ensino, vemos que:

(...) aquilo que o aluno pode realizar com ajuda, em determinado momento, poderá realizar de maneira independente mais tarde, e que o fato de participar da tarefa conjuntamente com um colega mais competente ou experiente é, precisamente, o que provoca as reestruturações e as mudanças nos esquemas de conhecimento que tornarão possível essa atuação independente. (ONRUBIA, 2003, 127 p.)

Dentro do pensamento construtivista, esse colega mais experiente é o professor, no nosso caso o regente/educador, e este processo de desenvolvimento das habilidades musicais dos coralistas, construídas através de sua ajuda, são parte integrante da metodologia de trabalho dentro do Comunicantus: Laboratório Coral, que busca o desenvolvimento das necessidades de aprendizagem dos integrantes de seus coros de forma consciente, para que em outros momentos seus conhecimentos possam ser utilizados por eles de forma autônoma. Para tal, a atividade a seguir foi desenvolvida da seguinte maneira:

- Iniciar com a associação estabelecendo as seguintes imagens aos determinados sons (conforme descrito no item 4.2.1.):

Glissando descendente a uma linha diagonal descendente

Glissando ascendente a uma linha diagonal ascendente

- A seguir estabeleça com o coro as seguintes associações:

Som seccionado (notas curtas):

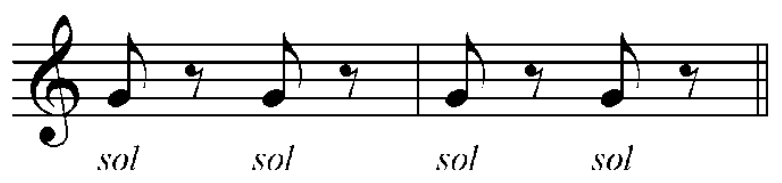

Som contínuo (notas longas):

a) 


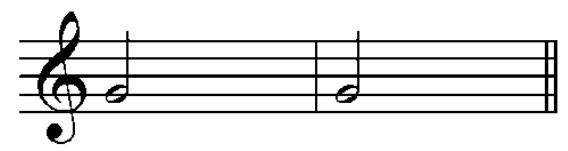

b) notas repetidas de igual duração

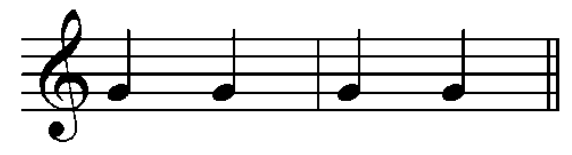

c)

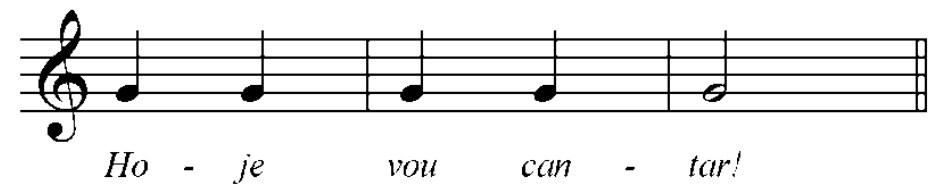

$2^{\mathrm{a}}$ Fase:

Dividir em dois grupos, com notas diferentes para cada:

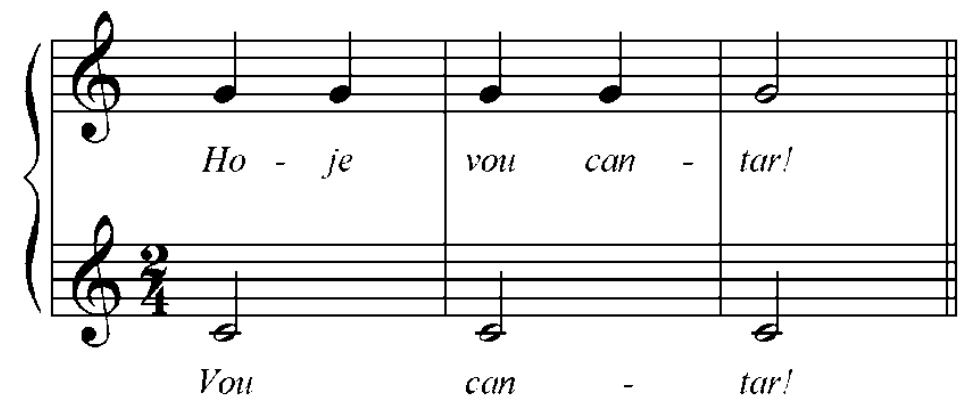

$3^{\mathrm{a}}$ Fase:

Agir como na $2^{\text {a }}$ fase, mas agora dividir em três grupos: 


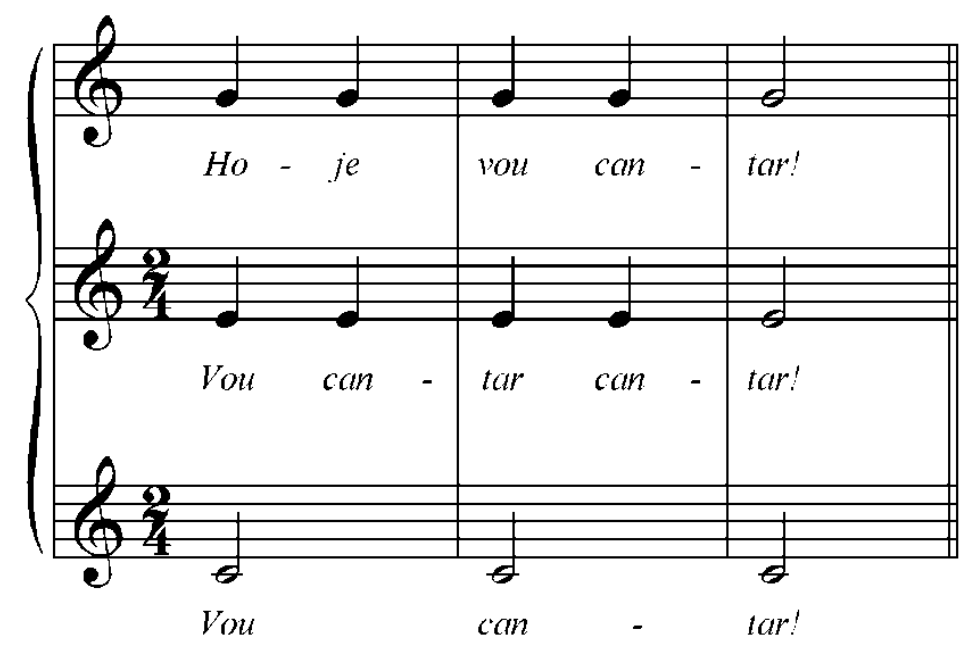

Obs.: é importante que todos os naipes (ou grupos) alternem as vozes do exercício para que experimentarem as alternativas oferecidas pela atividade na sua plenitude, assim possibilitando sua escuta simultânea a partir de todas as possibilidades propostas e adquirir a segurança necessária para cantar em um coro sem se influenciar pelas outras vozes.

Através deste procedimento poderemos trabalhar com os coralistas os seguintes pontos do referencial:

- Afinação das alturas;

- Correção e qualidade na realização dos fraseados da música;

- Manutenção da afinação ao longo da peça;

- Qualidade de afinação dentro dos naipes - afinação das melodias;

- Qualidade de afinação entre os naipes - afinação das simultaneidades;

- Consciência física da emissão sonora (memória da tessitura);

- Consciência auditiva do próprio som;

- Consciência de sua nota na harmonia;

- Percepção das outras vozes;

- Promover a prática do canto coral a 2 vozes e a habilidade para tanto. 
1.6. Atividade para cantar arpejo maior.

Objetivos:

Esta atividade irá trabalhar o aspecto da afinação coral da entoação do acorde maior, a partir do desenvolvimento do trabalho melódico com sua referente escala até o quinto grau. Sugerimos trabalhar assim:

- Cantar uma escala maior ascendente do primeiro ao quinto grau;

- Cantar uma escala maior descendente do quinto ao primeiro grau;

- Cantar uma escala maior do primeiro ao quinto grau nos sentidos ascendente e descendente;

- Estabelecer com o grupo uma imagem gráfica coletiva dos sons da escala, de forma a criar uma referência para eles; (sugiro a idéia de uma escada)

- Após a imagem estabelecida, brincar subindo e descendo os degraus um por vez, depois a cada dois, formando o arpejo;

- Trabalhar com todos para cantarem o arpejo juntos;

- Cantar o arpejo a partir da mesma nota e dividir em três grupos da seguinte forma:

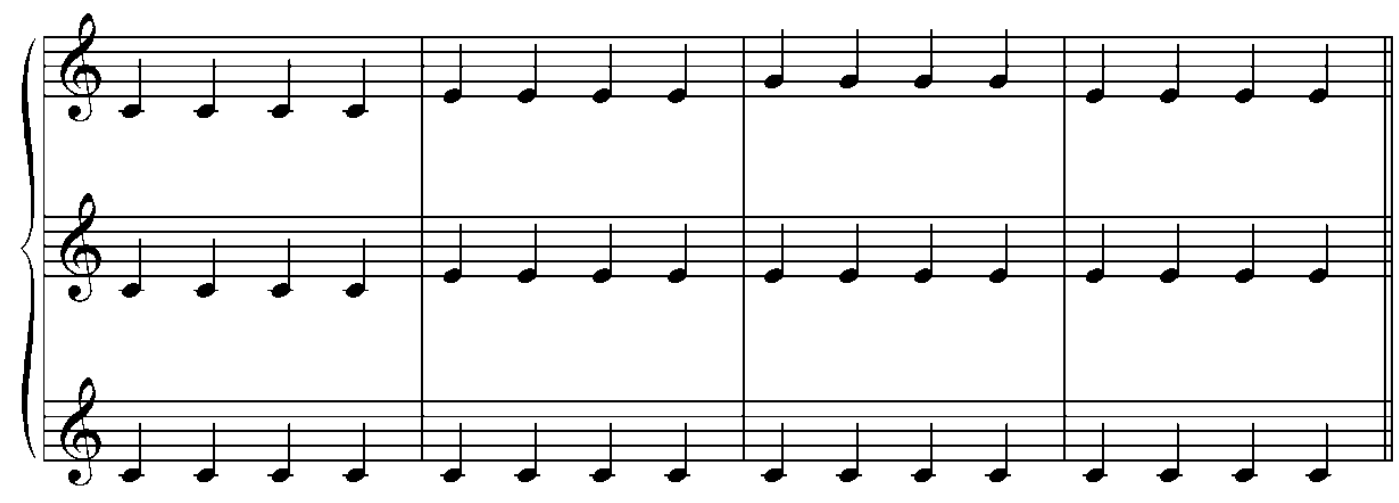

Obs.: os grupos deverão passar por todas as vozes do exercício. Sugiro cantar em cânone ou individualmente como na atividade 4.2.2, veja exemplo a seguir: 


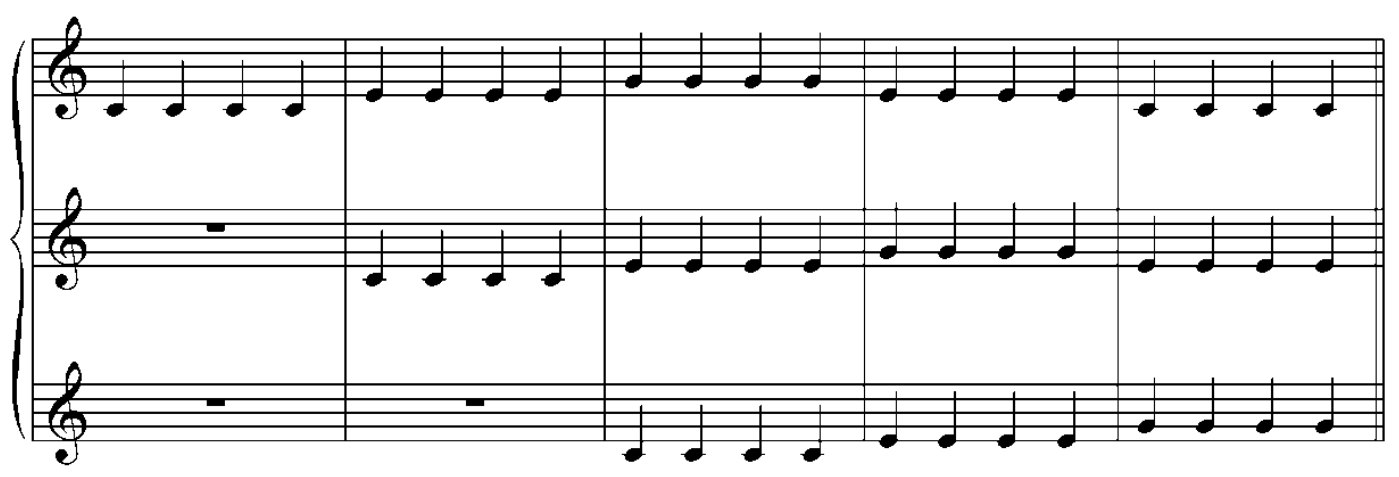

Através deste procedimento poderemos trabalhar com os coralistas os seguintes pontos do referencial:

- Afinação das alturas;

- Cantar intervalos melódicos ascendentes e descendentes;

- Correção e qualidade na realização dos fraseados da música;

- Manutenção da afinação ao longo da peça;

- Qualidade de afinação entre os naipes - afinação das simultaneidades;

- Consciência física da emissão sonora (memória da tessitura);

- Consciência auditiva do próprio som;

- Consciência de sua nota na harmonia;

- Consciência e compreensão melódica;

- Percepção das outras vozes;

- Promover a prática do canto coral a 3 vozes e a habilidade para tanto. 
1.7. Melodias descendentes

Objetivos:

Desenvolver a habilidade para cantar melodias descendentes de maneira afinada.

Esta foi uma das principais necessidades de aprendizagem demonstradas pelos coralistas do Coral Oficina Comunicantus. Sendo assim pensamos em trabalhar o desenvolvimento desta habilidade da seguinte maneira:

- utilizar exercícios de postura física e respiração, para relembrar as questões sobre o apoio para o canto, fator primordial para a emissão e afinação das notas.

- Cantar com os coralistas apoiados pelo piano tons inteiros na seguinte seqüência de intervalos:

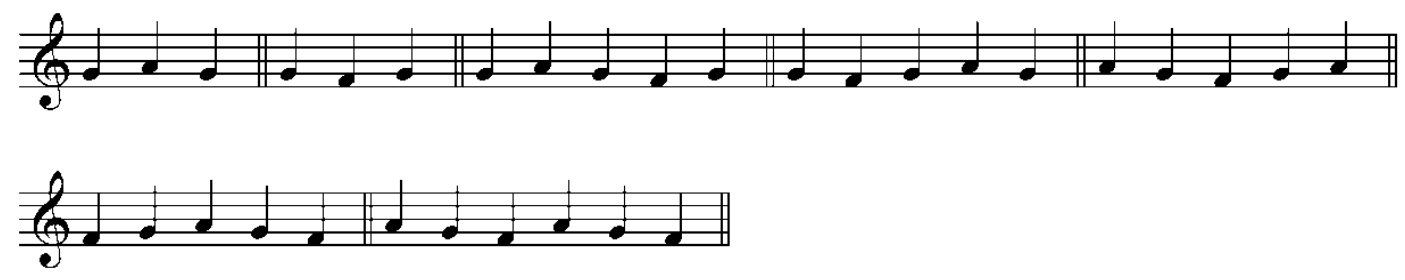

- Acrescentar a nota mi: 

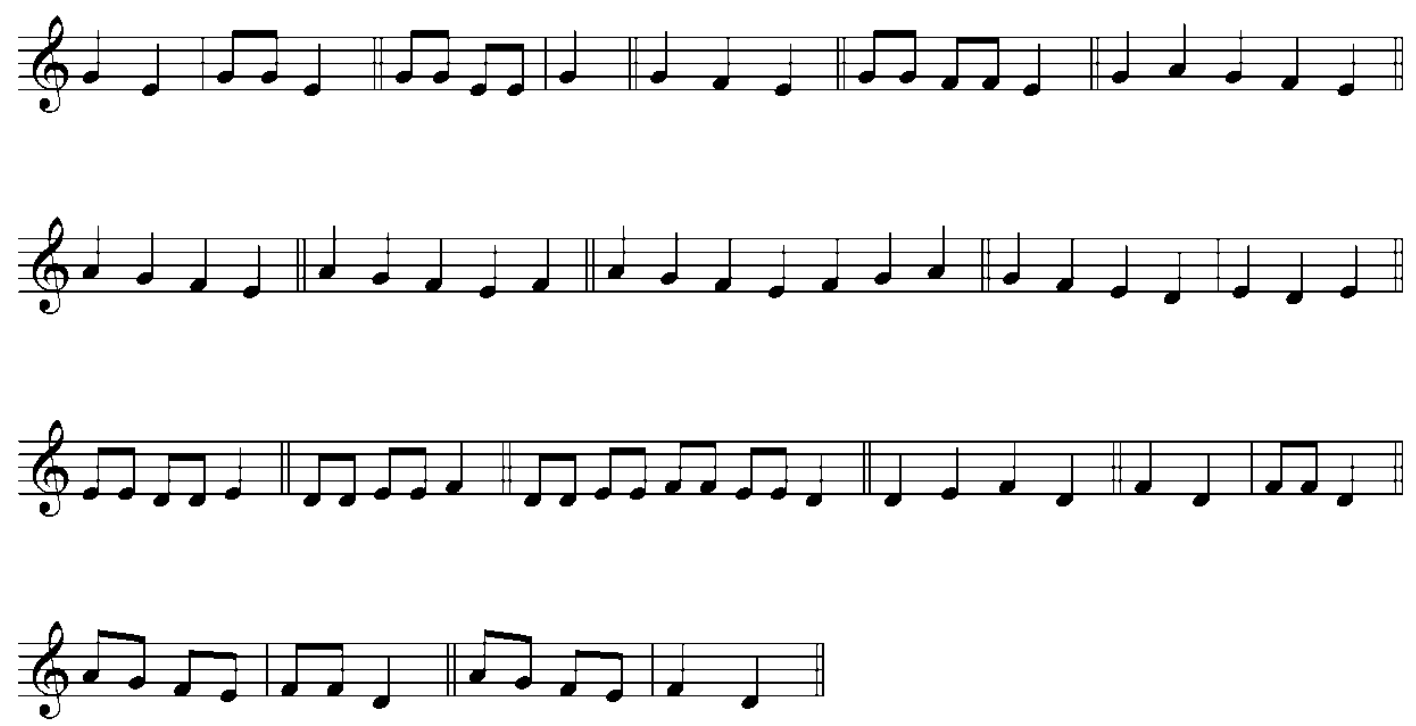

- A partir de então colocar o primeiro verso da canção “A lua depois da chuva” de Osvaldo Lacerda (se encontra nos anexos):

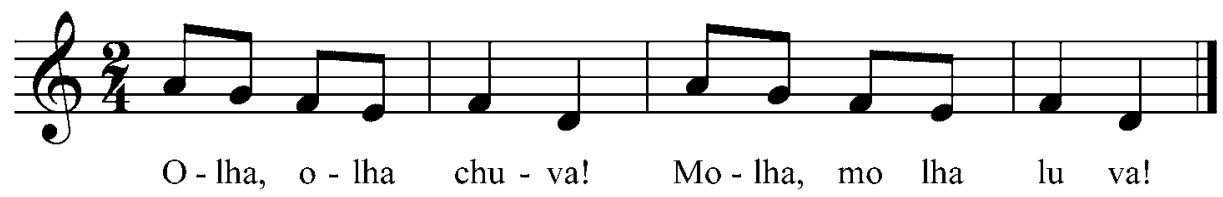

- Se for possível, execute este primeiro trecho da obra como exercício a duas vozes:

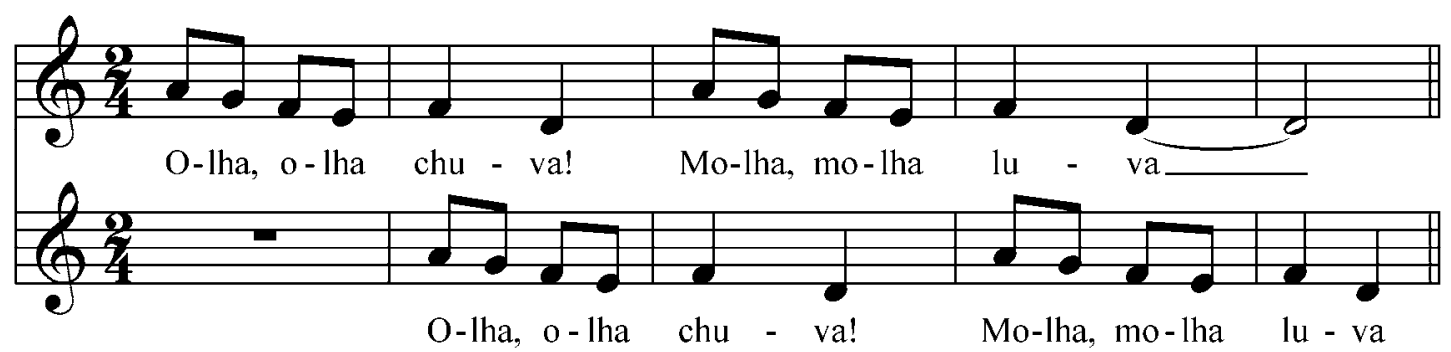

Através deste procedimento poderemos trabalhar com os coralistas os seguintes pontos do referencial: 
- Afinação das alturas;

- Cantar intervalos melódicos ascendentes e descendentes;

- Postura corporal geral do coro;

- Correção e qualidade na realização dos fraseados da música;

- Qualidade de afinação dentro dos naipes - afinação das melodias;

- Qualidade de afinação entre os naipes - afinação das simultaneidades;

- Consciência física da emissão sonora (memória da tessitura);

- Consciência auditiva do próprio som;

- Consciência e compreensão melódica;

- Percepção das outras vozes;

- Promover a prática do canto coral a 2 vozes e a habilidade para tanto.

1.8. Atividade com melodias contrárias (duas vozes)

Objetivos:

Esta atividade pretende ajudar o desenvolvimento da escuta melódica dos coralistas a partir da criação de uma independência auditiva com relação ao movimento melódico que as vozes podem fazer durante sua execução.

Como já mencionamos na atividade anterior, Onrubia nos fala sobre a utilização de ferramentas de aprendizagem que possam servir como referências úteis para situações futuras. Desta maneira, esta atividade se propõe a trabalhar o recurso contrapontístico conhecido como movimento contrário das vozes, que está contido em diversas obras do repertório e que na verdade está presente na própria origem do que hoje concebemos como canto coral.

- Veja os seguintes exemplos a duas vozes:
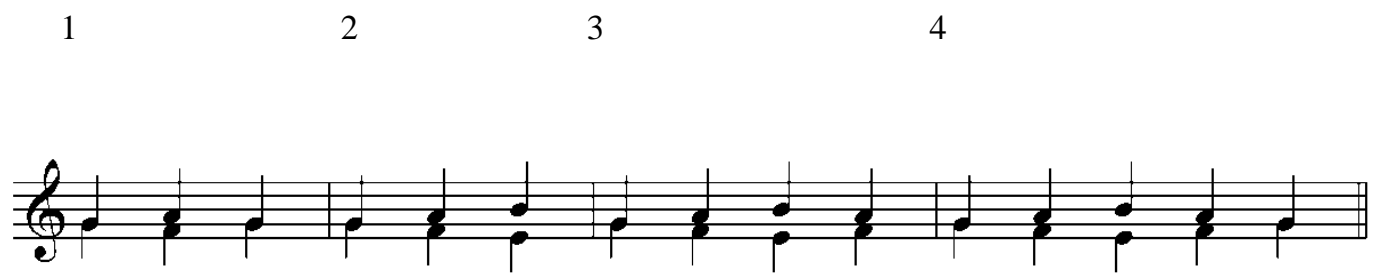
- Cada grupo que cantar as linhas melódicas (com nome de nota) que tem movimentos independentes estará treinando suas habilidades de escuta melódica e concentração, para que o efeito sonoro (no caso o resultado dos intervalos harmônicos criados) não interfira na entoação dos coralistas.

- O uníssono será o ponto de partida e chegada do caminho melódico a ser trilhado por eles;

- Pedir aos coralistas caminharem enquanto cantam, ou seja, deixá-los parados em fila indiana enquanto cantam o uníssono e a cada mudança de nota pedir para darem um passo lateral quando muda nota da melodia que estão cantando, nota ascendente um passo à direita, descendente, um passo à esquerda.

Obs.: Lembrar-se, sempre de inverter as melodias entre os grupos para que todos possam desenvolver a escuta de forma consciente e não a simplesmente imitativa.

Através deste procedimento poderemos trabalhar com os coralistas os seguintes pontos do referencial:

- Afinação das alturas;

- Cantar intervalos melódicos ascendentes e descendentes;

- Memorização melódica;

- Correção e qualidade na realização dos fraseados da música;

- Qualidade de afinação dentro dos naipes - afinação das melodias;

- Qualidade de afinação entre os naipes - afinação das simultaneidades;

- Consciência física da emissão sonora (memória da tessitura);

- Consciência auditiva do próprio som;

- Consciência e compreensão melódica;

- Percepção das outras vozes;

- Promover a prática do canto coral a 2 vozes e a habilidade para tanto. 


\subsection{Atividade com melodias contrárias II}

Objetivos:

Esta atividade dá seqüência ao desenvolvimento das mesmas habilidades tratadas na atividade anterior, com os coralistas partindo de notas diferentes e cantado o uníssono no meio do caminho melódico, quando retorna ao ponto inicial separando-se novamente. Vejamos o exemplo abaixo:

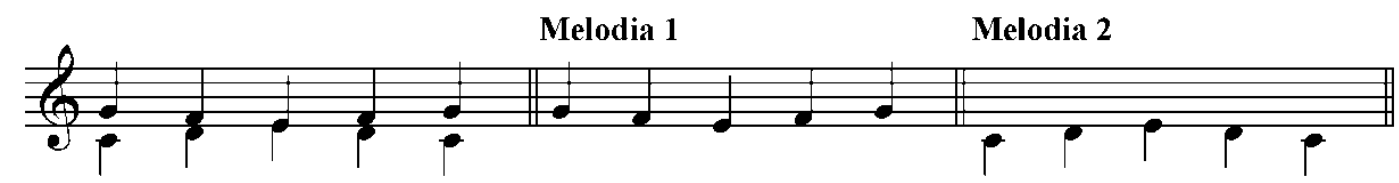

- Tendo aprendido a respectiva melodia podemos;

- Separar os grupos e cantar até o uníssono;

- Pedir aos grupos para cantar as duas melodias simultaneamente;

- Inverter as melodias entre os grupos;

Obs.: Pode-se executar a mesma melodia com outras formas rítmicas e com um texto para ajudar na assimilação.

Através deste procedimento poderemos trabalhar com os coralistas os seguintes pontos do referencial:

- Afinação das alturas;

- Cantar intervalos melódicos ascendentes e descendentes;

- Memorização melódica;

- Correção e qualidade na realização dos fraseados da música;

- Qualidade de afinação dentro dos naipes - afinação das melodias;

- Qualidade de afinação entre os naipes - afinação das simultaneidades;

- Consciência física da emissão sonora (memória da tessitura); 
- Consciência auditiva do próprio som;

- Consciência e compreensão melódica;

- Percepção das outras vozes;

- Promover a prática do canto coral a 2 vozes e a habilidade para tanto.

1.10. Atividade com melodias contrárias III

Objetivos:

Esta atividade continua o processo de desenvolvimento da escuta melódica, mas agora acrescenta o elemento contrapontístico conhecido como cruzamento de vozes.

Vamos utilizar uma escala maior do primeiro ao quinto graus, bastante trabalhada e conhecida pelos coralistas do Coro Oficina Comunicantus, pois se observarmos conceitos de ensino/aprendizagem veremos que para se aprender de maneira significativa e consciente é preciso: “Ter conhecimentos conceituais prévios organizados, pertinentes e relevantes, com os quais conectar a nova informação objeto de aprendizagem” (MAURI, 2003, 105 p.) . Vejamos o exemplo a seguir:

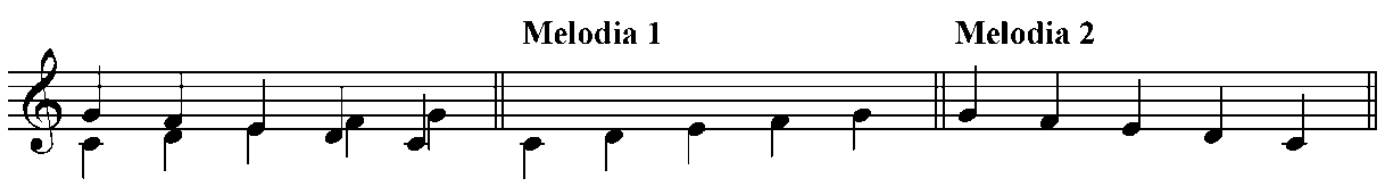

Obs.: mantive as astes em sentido contrário para deixar as linhas melódicas mais evidentes.

Sugestão de trabalho:

- Cantar a melodia 1 (todos); 
- Cantar as duas, primeiro a 1 depois a 2 (todos);

- Cantar a melodia 2 (todos);

- Dar uma melodia para cada grupo e trabalhe o procedimento de pergunta e resposta;

- cantar as melodias simultaneamente.

Obs.: criar com os grupos uma referência gráfica da direção das melodias deixandoos conscientes de que cada movimento realiza.

Através deste procedimento poderemos trabalhar com os coralistas os seguintes pontos do referencial:

- Afinação das alturas;

- Cantar intervalos melódicos ascendentes e descendentes;

- Qualidade de afinação dentro dos naipes - afinação das melodias;

- Qualidade de afinação entre os naipes - afinação das simultaneidades;

- Consciência física da emissão sonora (memória da tessitura);

- Consciência auditiva do próprio som;

- Consciência e compreensão melódica;

- Percepção das outras vozes;

- Promover a prática do canto coral a 2 vozes e a habilidade para tanto.

1.11. Atividade para notas iguais com melodia paralela ascendente; Objetivos:

Esta atividade foi desenvolvida para estimular a habilidade de cantar de maneira afinada notas longas enquanto se ouve uma melodia simultânea. Tal procedimento exige muita concentração dos coralistas durante sua realização, principalmente quando se formam os intervalos de segunda maior. Veja os exemplos a seguir: 
1)

2)

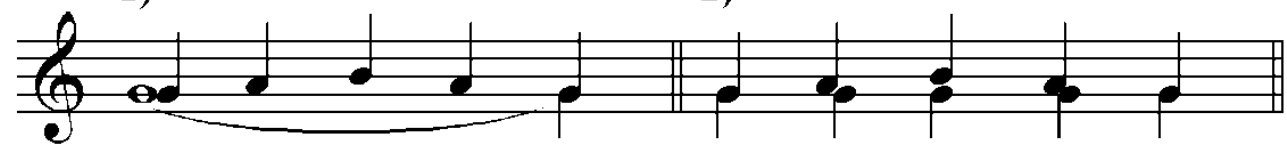

-Para melhor resultado de afinação, pedir aos coralistas para cantarem as melodias com nome de nota, pois isto vem sendo trabalhado desde o princípio dos exercícios, e este fator pode melhorar a memória da tessitura e gerar mais segurança para entoarem as notas.

- Pedir ao coro para cantar a nota longa (exemplo 1) apoiado pelo piano enquanto ele canta a melodia para facilitar a compreensão da atividade. Depois inverter com eles, ou seja, o regente canta a melodia e eles a nota longa e, só então, os dividir em dois grupos para realizar o primeiro exemplo. Para o segundo, explicar que desta vez um grupo cantará repetidamente a mesma nota da linha debaixo (nota sol) enquanto o outro cantará a mesma melodia que já havia executado anteriormente.

Através deste procedimento poderemos trabalhar com os coralistas os seguintes pontos do referencial:

- Afinação das alturas;

- Cantar intervalos melódicos ascendentes e descendentes;

- Qualidade de afinação dentro dos naipes - afinação das melodias;

- Qualidade de afinação entre os naipes - afinação das simultaneidades;

- Consciência auditiva do próprio som;

- Percepção das outras vozes

- Correção e qualidade na realização dos fraseados da música;

- Manutenção da afinação ao longo da peça;

- Promover a prática do canto coral a 2 vozes e a habilidade para tanto. 
1.12. Atividade para notas iguais com melodia paralela descendente;

Objetivos:

Diminuir a influência da melodia principal na execução do naipe que canta a melodia secundária.

Esta atividade deve ser realizada com os mesmos passos usados na atividade anterior, pois assim dará seqüência ao desenvolvimento num nível mais avançado para o desenvolvimento desta habilidade com o Coral Oficina Comunicantus, que ao longo do processo, apresentou bastante dificuldade para entoar melodias descendentes. Vejamos os exemplos a seguir:

1)

2)

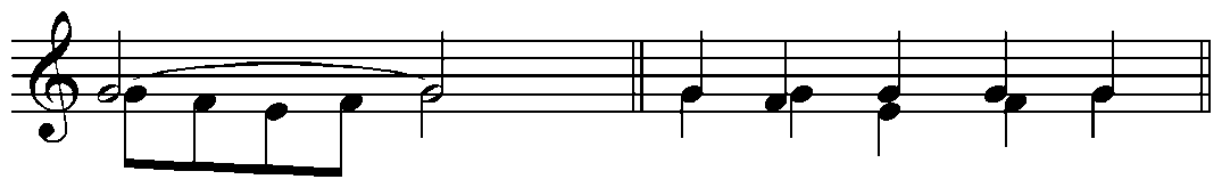

Obs.: Outra possibilidade é mudar as melodias trabalhadas nesta atividade e na anterior substituindo-as por arpejos. Veja os exemplos:

1)

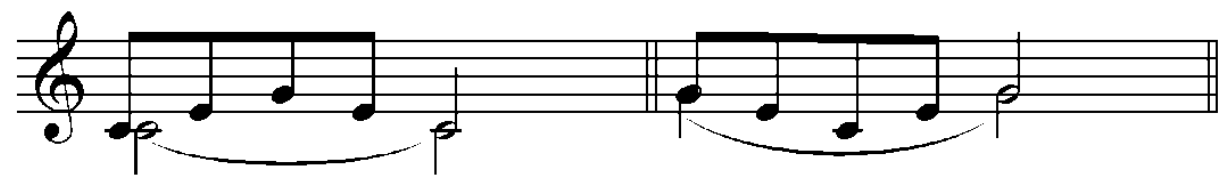

Através deste procedimento poderemos trabalhar com os coralistas os mesmos pontos do referencial citados na atividade anterior, porém com um nível de dificuldade mais avançado. 
1.13. Atividade com duas vozes cantadas em movimento contrário.

Objetivos:

Esta atividade busca desenvolver a habilidade de cantar melodias em movimento contrário sem se influenciarem mutuamente. Para tal, trabalhar a seqüência melódica a seguir:

1)

2)

Juntar os 2 grupos

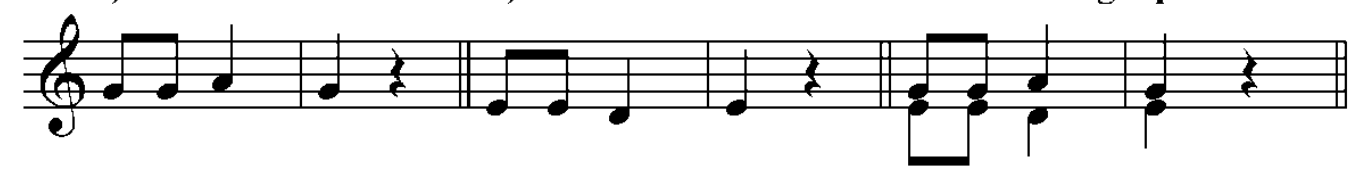

- Ensinar uma das melodias de cada vez, para o coro todo ao mesmo tempo;

- Divida-o em dois grupos e realize o procedimento de pergunta e resposta com as duas melodias, alternado-as entre eles, ou seja, os dois grupos aprenderão as melodias.

- Quando a entoação estiver fluente, pedir para cantarem as duas melodias juntas, sem esquecer de invertê-las entre os grupos de forma a experimentarem todas as possibilidades do exercício, pois quando um naipe sabe cantar a melodia do outro pode facilitar a execução de sua própria linha quando cantam juntos, por terem maior clareza para diferenciá-las.

Através deste procedimento poderemos trabalhar com os coralistas os seguintes pontos do referencial:

- Afinação das alturas;

- Cantar intervalos melódicos ascendentes e descendentes;

- Correção e qualidade na realização dos fraseados da música;

- Manutenção da afinação ao longo da peça; 
- Qualidade de afinação entre os naipes - afinação das simultaneidades;

- Consciência auditiva do próprio som;

- Consciência de sua nota na harmonia;

- Consciência e compreensão melódica;

- Percepção das outras vozes.

1.14. Atividade com Ostinato ${ }^{42}$

Objetivo:

Esta atividade busca ajudar o desenvolvimento da escuta melódica dos coralistas, trabalhando o elemento do ostinato associado a melodias entoadas paralelamente a ele.

Sugestão de abordagem didática:

Ensinar aos coralistas uma linha melódica que se repete pode ajudar no desenvolvimento da escuta melódica trabalhando da seguinte forma:

- Ensinar uma melodia em ostinato para o coro até ficar fluente:

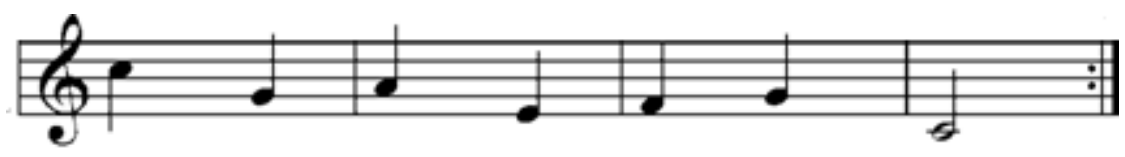

- Ensinar uma melodia abaixo que se encaixa com esse ostinato:

\footnotetext{
${ }^{42}$ Termo que se refere à repetição de um padrão musical por muitas vezes sucessivas. Um ostinato melódico pode ocorrer no baixo, como melodia numa voz superior ou simplesmente como uma sucessão de alturas repetidas (SADIE, 1994, p. 687)
} 


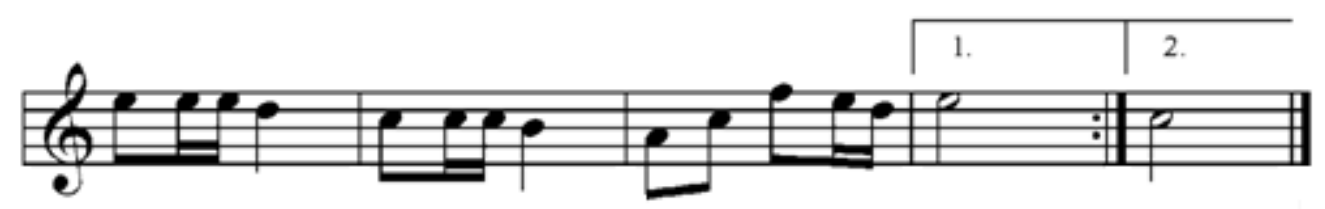

- Em seguida dividir o coro em dois grupos e pedir para cantarem as duas juntas:

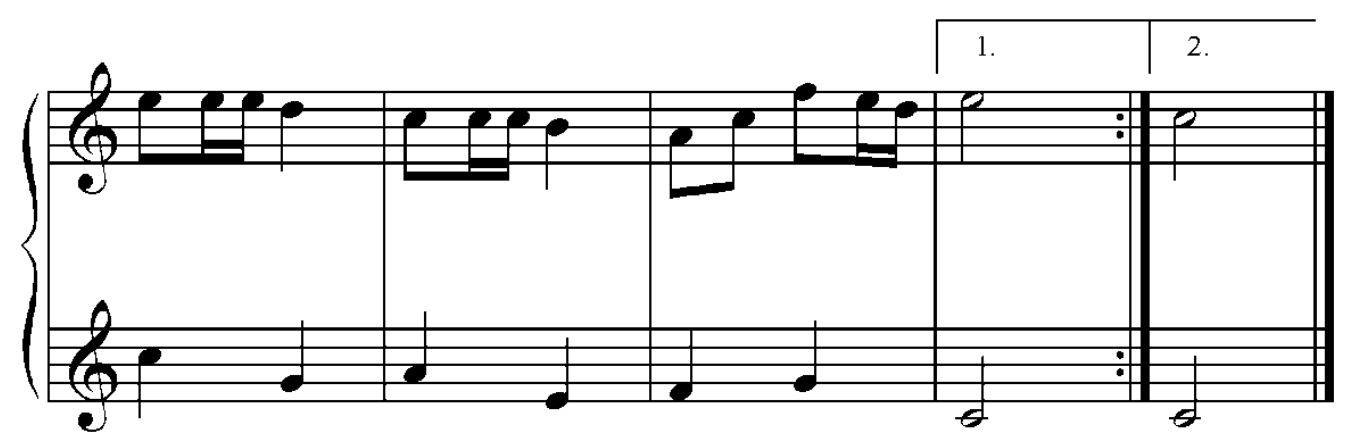

Obs. É possível criar outras melodias que se encaixem ao ostinato para desenvolver no coro a habilidade de cantar linhas diferentes de forma consciente.

Através deste procedimento poderemos trabalhar com os coralistas os seguintes pontos do referencial:

- Afinação das alturas;

- Cantar intervalos melódicos ascendentes e descendentes;

- Correção e qualidade na realização dos fraseados da música;

- Manutenção da afinação ao longo da peça;

- Qualidade de afinação entre os naipes - afinação das simultaneidades;

- Consciência auditiva do próprio som;

- Consciência e compreensão melódica;

- Percepção das outras vozes.

- Consciência física da emissão sonora (memória da tessitura);

- Consciência auditiva do próprio som;

- Consciência de sua nota na harmonia; 
- Promover a prática do canto coral a 2 vozes e a habilidade para tanto.

1.15. Atividades com melodias em tonalidade menor

Objetivos:

Desenvolver a habilidade de cantar e ouvir melodias em tonalidade menor. Esta atividade é a primeira de uma seqüência de três elaborada para desenvolver continuadamente tal habilidade.

Sugestão de abordagem didática:

- trabalhar com a seguinte seqüência de intervalos melódicos (com nome de nota):

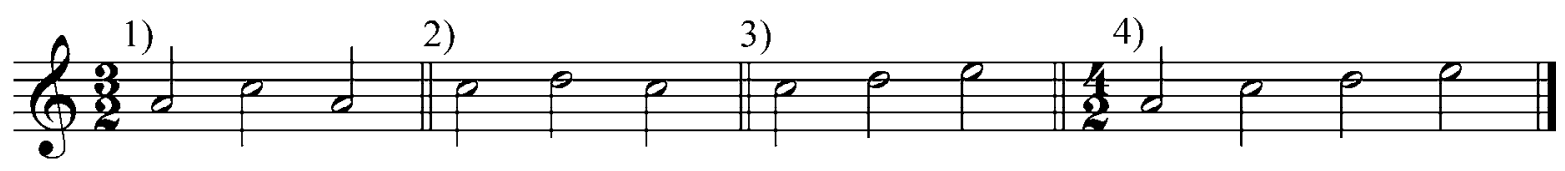

-Cantar os intervalos com os coralistas fazendo variações rítmicas até que sua entoação fique fluente. Sugiro como exemplo:

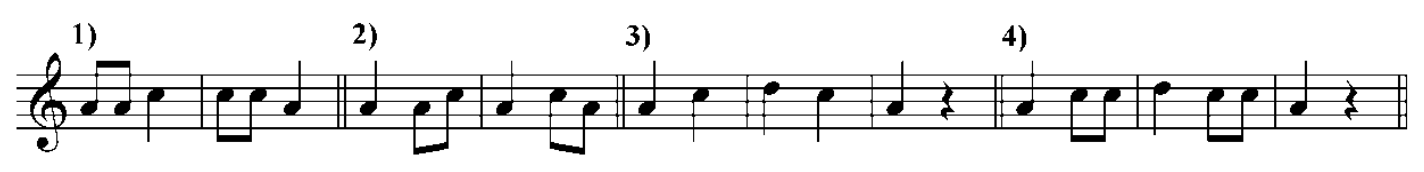

Através deste procedimento poderemos trabalhar com os coralistas os seguintes pontos do referencial: 
- Afinação das alturas;

- Cantar intervalos melódicos ascendentes e descendentes;

- Correção e qualidade na realização dos fraseados da música;

- Manutenção da afinação ao longo da peça;

- Consciência auditiva do próprio som;

- Consciência e compreensão melódica;

- Consciência física da emissão sonora (memória da tessitura);

- Consciência auditiva do próprio som;

- Memorização melódica.

1.16. Atividade com arpejos em tonalidade menor

Objetivos:

Continuar o desenvolvimento da habilidade de cantar e ouvir melodias em tonalidade menor.

A atividade anterior preparou a atenção auditiva dos coralistas para a execução de melodias e arpejos em tonalidade menor. Para continuar o desenvolvimento desta habilidade poderemos utilizar os mesmos intervalos reorganizados para oferecer aos coralistas a possibilidade de aprenderem naturalmente os aspectos referentes a execução de melodias e arpejos nesta tonalidade.

Como alternativa didática pode-se utilizar a seguinte seqüência de trabalho: 

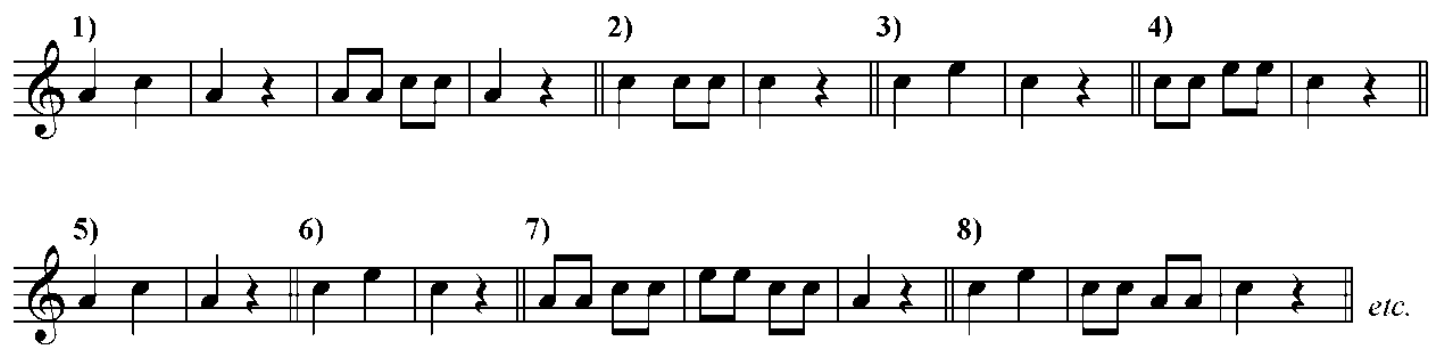

Obs.: Assim como no trabalho com o modo maior, pedir aos cantores para entoarem utilizando os nomes das notas, para ajudar a definir as relações intervalares e a memória da tessitura.

Através deste procedimento poderemos trabalhar com os coralistas os seguintes pontos do referencial:

- Afinação das alturas;

- Cantar intervalos melódicos ascendentes e descendentes;

- Memorização melódica;

- Correção e qualidade na realização dos fraseados da música;

- Manutenção da afinação ao longo da peça;

- Qualidade de afinação dentro dos naipes - afinação das melodias;

- Consciência física da emissão sonora (memória da tessitura);

- Consciência auditiva do próprio som;

- Consciência e compreensão melódica; 
1.17. Atividade para cantar a três vozes em tonalidade menor

Objetivos:

Conectar os conteúdos abordados nas duas atividades anteriores para obter melhor resultado na performance vocal com melodias menores a três vozes.

A idéia desta é atividade irá trabalhar o aspecto da afinação coral da entoação do acorde menor a partir do desenvolvimento do trabalho melódico com seu referente arpejo até o quinto grau. Embora já tenhamos desenvolvido nas duas atividades anteriores a sonoridade do arpejo menor, retomar esse trabalho com o coro antes desta atividade pode ser muito interessante, pois não é porque um conteúdo foi trabalhado com sucesso anteriormente que não precise mais ser abordado, relembrando a citação de Ramos mencionada anteriormente. No caso desta atividade, relembrar os aspectos já vistos ajudará na aprendizagem do que virá a ser desenvolvido, ou seja, estamos utilizando o conceito de ZDP para realizar a integração com os novos conteúdos a serem aprendidos pelos coralistas. Para tal, sugerimos trabalhar na seguinte ordem:

- Relembrar rapidamente os exemplos melódicos da atividade anterior;

- Pedi para todo o coro cantar uma terça menor (lá-dó), em seguida cantar com eles diversas possibilidades rítmicas com este intervalo (como foi exemplificado na atividade anterior), depois dividir em dois grupos e afinar uma nota com cada um, mas sempre sustentando, para obter o som do intervalo harmônico;

- Proceder da mesma maneira, agora com dó-mi;

- Pedir a eles para cantarem o arpejo completo (lá-dó-mi), todos juntos sem divisão de naipes;

- Em seguida, dividir o coro em três naipes com uma nota para cada, depois pedir para cantarem da seguinte forma: 


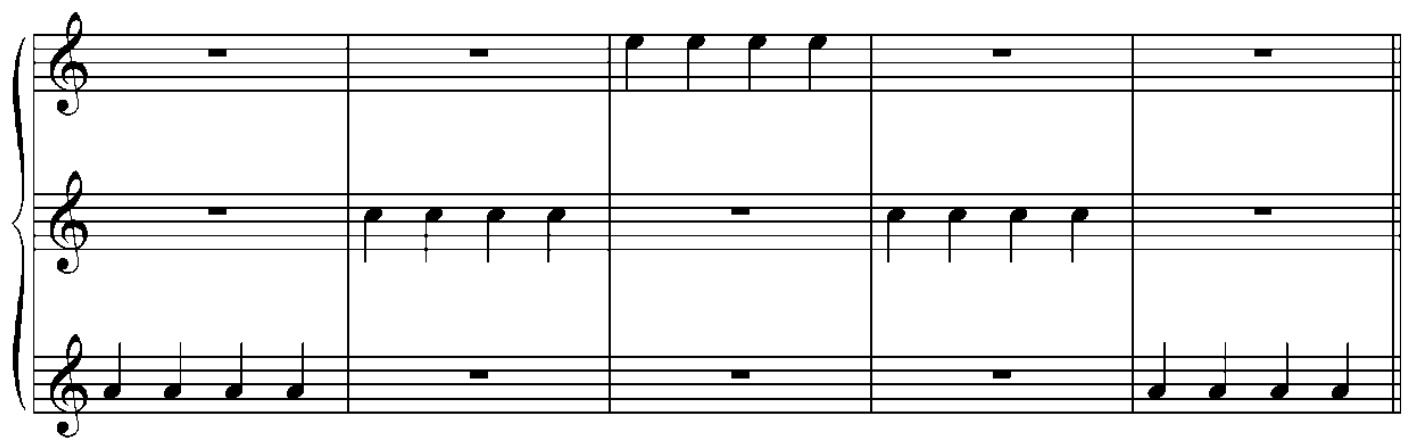

- Como todos já saberão todas as notas, inverter as vozes, de forma que todos os naipes cantem as notas do arpejo;

- Em seguida pedir para cantarem como segue:

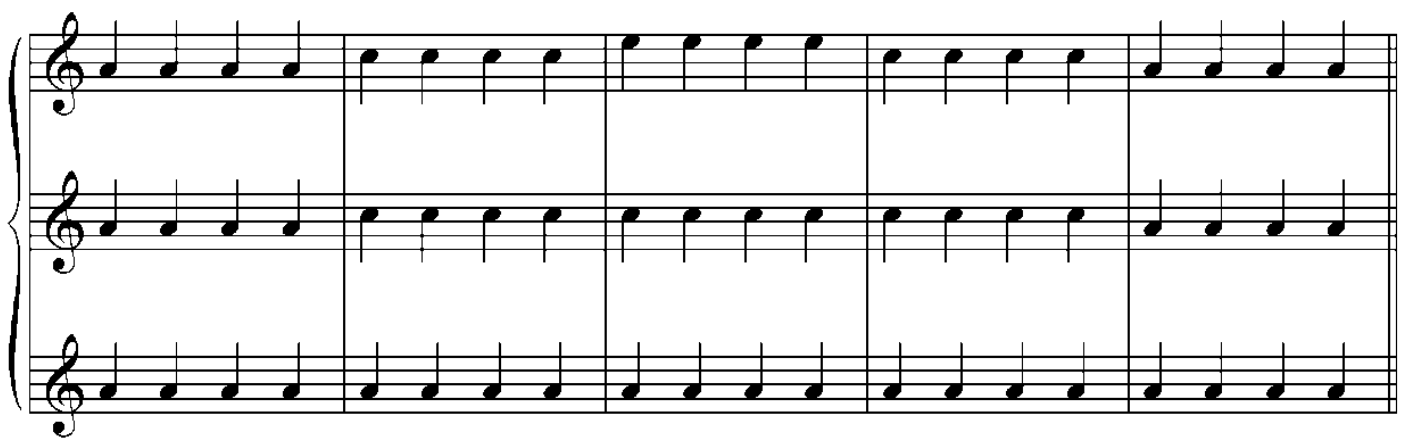

- para concluir a atividade, pedir para cantar o arpejo em forma de um cânone a três vozes:

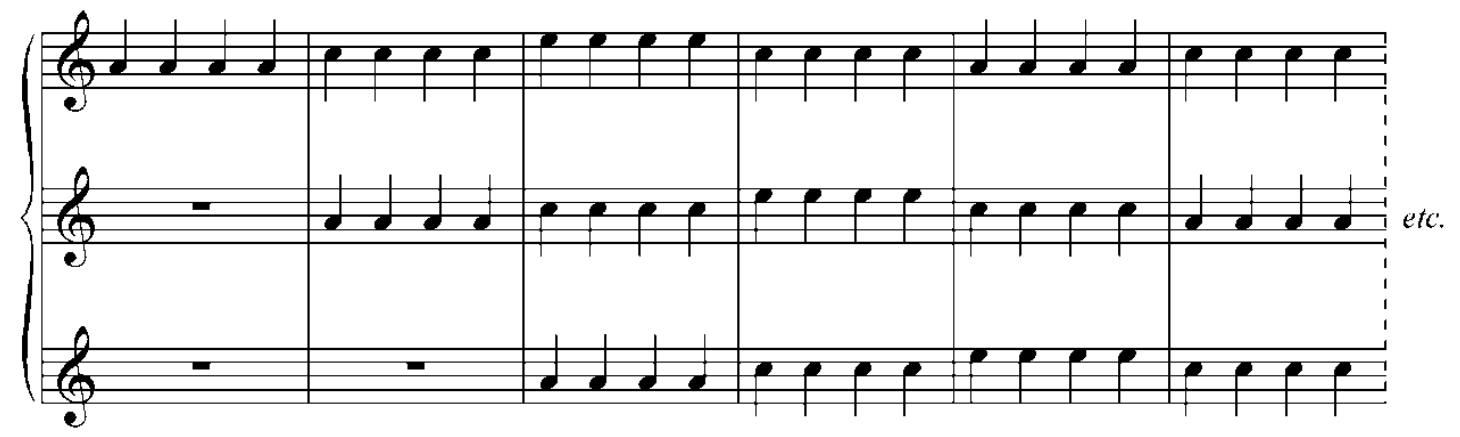

Através deste procedimento poderemos trabalhar com os coralistas os seguintes pontos do referencial: 
- Afinação das alturas;

- Cantar intervalos melódicos ascendentes e descendentes;

- Memorização melódica;

- Manutenção da afinação ao longo da peça;

- Qualidade de afinação dentro dos naipes - afinação das melodias;

- Qualidade de afinação entre os naipes - afinação das simultaneidades;

- Consciência física da emissão sonora (memória da tessitura);

- Consciência auditiva do próprio som;

- Consciência de sua nota na harmonia;

- Consciência e compreensão melódica;

- Percepção das outras vozes;

- Promover a prática do canto coral a 3 vozes e a habilidade para tanto.

1.18. Atividade para introduzir o semitom

Objetivos:

Introduzir o intervalo de semitom para desenvolvimento da escuta melódica.

O semitom é um parâmetro musical que requer bastante atenção para sua aprendizagem e execução. Sua combinação com os tons, dentro de uma melodia, exige uma escuta melódica mais apurada por parte do coralista, e trabalhar este elemento paulatinamente pode levar o regente a obter bons resultados na melhoria da qualidade de afinação e na performance vocal de seu grupo.

Desta forma, pensamos os seguintes exemplos musicais, com intervalos capazes de estimular a escuta melódica dos semitons dentro do repertório coral: 

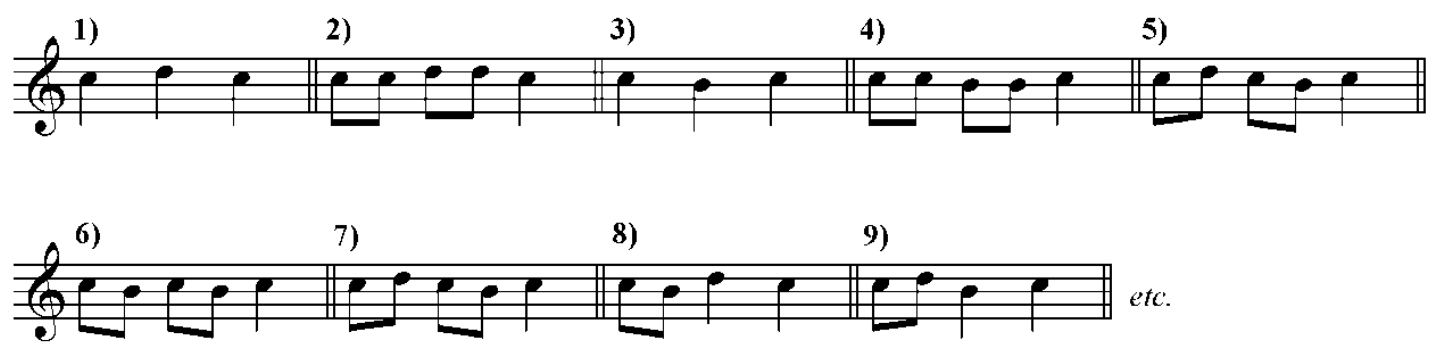

Através deste procedimento poderemos trabalhar com os coralistas os seguintes pontos do referencial:

- Afinação das alturas;

- Cantar intervalos melódicos ascendentes e descendentes;

- Percepção e capacidade de emissão dos cromatismos;

- Memorização melódica;

- Correção e qualidade na realização dos fraseados da música;

- Manutenção da afinação ao longo da peça;

- Qualidade de afinação dentro dos naipes - afinação das melodias;

- Consciência física da emissão sonora (memória da tessitura);

- Consciência auditiva do próprio som;

- Consciência e compreensão melódica;

1.19. Atividade para desenvolver a percepção da diferença entre alturas

Objetivos:

Desenvolver a habilidade de perceber as diferenças de alturas entre os intervalos de quinta justa, e entoá-los com uma escuta consciente de suas simultaneidades. 
Esta atividade, em um primeiro momento, parece tratar de uma questão um tanto óbvia, mas para um regente de coros vocacionais, desenvolver tal habilidade com os coralistas é ponto fundamental para o estímulo da escuta melódica. Várias pessoas que estão nos coros não percebem diferenças entre as notas musicais, sobretudo quando aprendem música ensinada diretamente com o texto, sua atenção pode ficar direcionada quase exclusivamente ao elemento lírico a ponto de não ouvir (perceber) as diferenças entre os sons que são entoados enquanto são ensinadas. Sabemos que há diversas outras causas para as pessoas não conseguirem cantar melodias de maneira considerada afinada, Sobreira em seu trabalho, aborda diversas origens da desafinação que vão desde questões de ordem cultural até de ordem neurológica ou física. Deixando estes aspectos a margem, observamos que a atenção voltada para perceber nuances dos sons precisa ser desenvolvida e, os procedimentos de abordagem devem ser elaborados de forma que as próprias pessoas estabeleçam as relações entre a escuta dos sons e sua emissão. O trabalho do regente deve oferecer condições para seus coralistas perceberem que há uma série de pontos que devem ser dominados por eles para conseguirem cantar corretamente, dentre os quais estão diretamente interligados: percepção melódica, percepção física, a percepção da emissão sonora e a compreensão dos eventos sonoros musicais.

Desta acreditamos ser importante para a evolução do coro elaborar atividades que estimulem todo esse processo. Sugiro como possibilidade para trabalhar tal habilidade a seguinte abordagem didática:

- No início do ensaio fazer uma explicação para chamar a atenção do coro para as diferenças de altura entre os sons. Mostre a eles com o auxílio do piano o que são sons graves, agudos e médios nas regiões mais extremas.

- Depois explicar que isso também pode ocorrer com notas mais próximas e tocar exemplos para fazê-los perceber tais diferenças.

- Tocar uma nota como referência e em seguida tocar outra e perguntar a eles se é mais grave ou mais aguda que a anterior. Repetir esse procedimento algumas vezes, em outras alturas para estimular a escuta consciente deles.

- Como na figura a seguir, tocar uma nota qualquer e pedir para o grupo entoá-la usando a sílaba lá (exemplo 1):

Obs1.: Caso haja algum coralista monotônico identifique-o para depois fazer um trabalho mais direcionado. 
- Tocar outra nota uma quinta acima da anterior e pedir para cantarem (exemplo 2).

- Dividir o coro em dois naipes e afinar uma nota com cada grupo (exemplo 3).

- Pedir para um grupo cantar a nota grave e sustentá-la, em seguida pedir para o outro grupo cantar sua nota, formando assim o intervalo de quinta justa em duas modalidades, melódico e harmônico (exemplos 4 e 5).

- Pedir para cantarem o intervalo simultaneamente (exemplo 6).

1) 2) 3)

4)

5)

6)

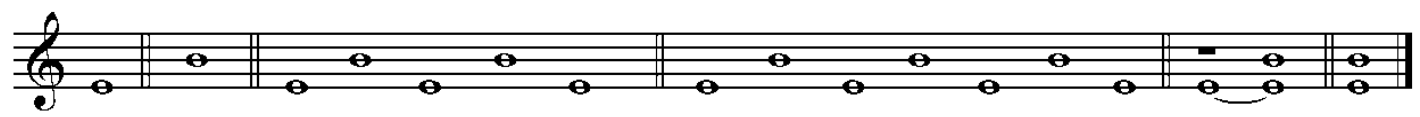

Obs.2: Para complementar o trabalho não se esqueça de inverter as notas entre os grupos.

Através deste procedimento poderemos trabalhar com os coralistas os seguintes pontos do referencial:

- Afinação das alturas;

- Manutenção da afinação ao longo da peça;

- Qualidade de afinação dentro dos naipes - afinação das melodias;

- Consciência física da emissão sonora (memória da tessitura);

- Consciência auditiva do próprio som;

- Consciência e compreensão melódica;

- Qualidade de afinação entre os naipes - afinação das simultaneidades;

- Postura corporal geral do coro;

- Consciência de sua nota na harmonia;

- Percepção das outras vozes. 
1.20. Atividade para entoação de intervalos melódicos

Objetivos:

Trabalhar a afinação das melodias de forma consciente através do desenvolvimento da escuta melódica dos coralistas.

Para ajudar o coro a cantar uma melodia de maneira mais afinada, cantar os intervalos da música com o nome das notas antes de colocar o texto pode ser uma solução bastante eficaz. Para esta atividade escolhemos um trecho da peça Baião de Ninar de Edino Krieger, que fez parte do repertório ensaiado pelo Coral Oficina Comunicantus, e que o coro apresentou algumas necessidades de aprendizagem em sua execução. Vejamos o trecho escolhido:

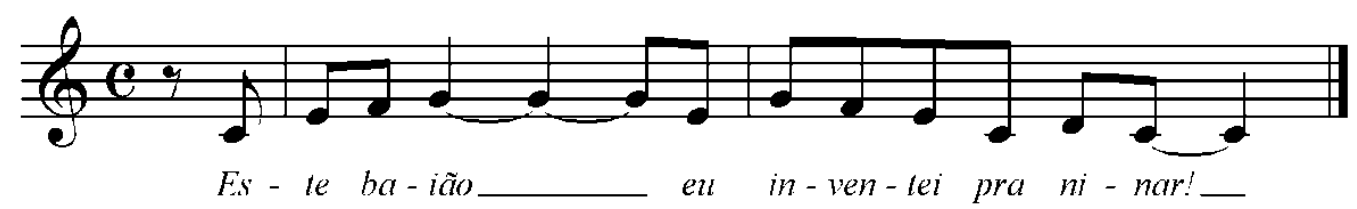

- Como procedimento didático, pensamos na possibilidade de desconstruir a melodia e ensinála em trechos pequenos. Ensinar dois intervalos (dó-mi e mi-dó), depois mais dois, e vá somando-os gradativamente até entoarem com fluência e afinação. Veja as sugestões de abordagem onde cada compasso é uma etapa do processo de aprendizagem:

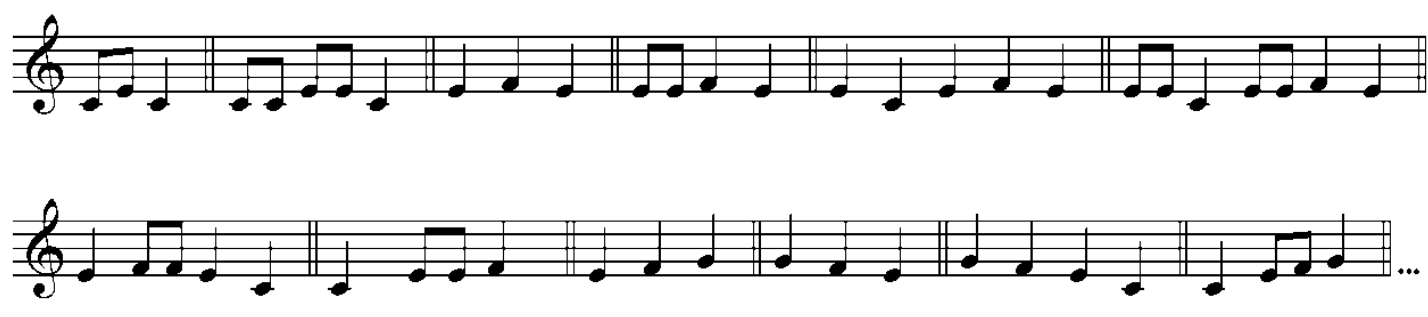


- Este procedimento deve continuar até cantarem a frase completa. Quando isso ocorrer coloque o texto.

Através deste procedimento poderemos trabalhar com os coralistas os seguintes pontos do referencial:

- Afinação das alturas;

- Cantar intervalos melódicos ascendentes e descendentes;

- Percepção e capacidade de emissão dos cromatismos;

- Memorização melódica;

- Correção e qualidade na realização dos fraseados da música;

- Manutenção da afinação ao longo da peça;

- Qualidade de afinação dentro dos naipes - afinação das melodias;

- Consciência física da emissão sonora (memória da tessitura);

- Postura corporal geral do coro;

- Consciência auditiva do próprio som;

- Consciência e compreensão melódica; 
ANEXO A 


\section{Baião}
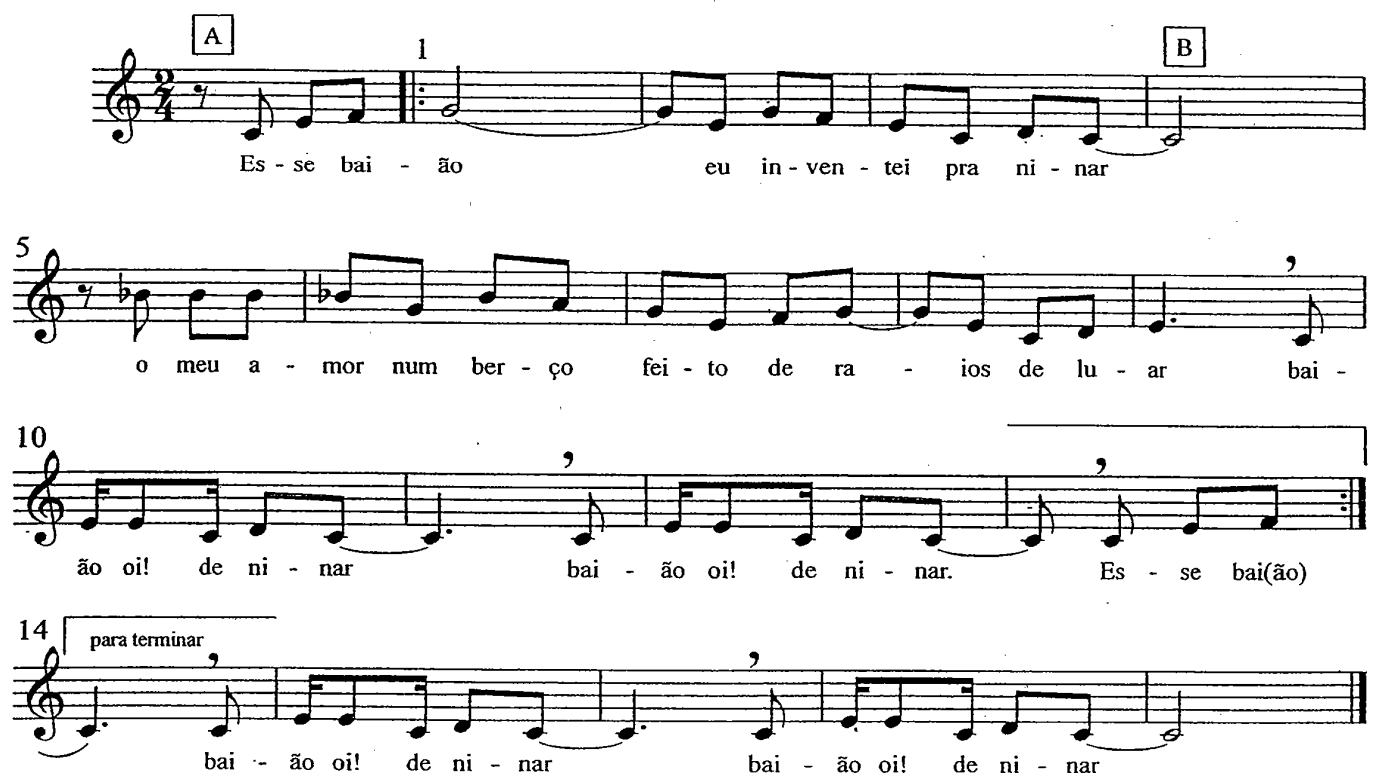
Comunicantus ISO DDATTCO- 2008 ORAL OFICNA

:ansctição: Viviane Valladão

Folclore do Recife
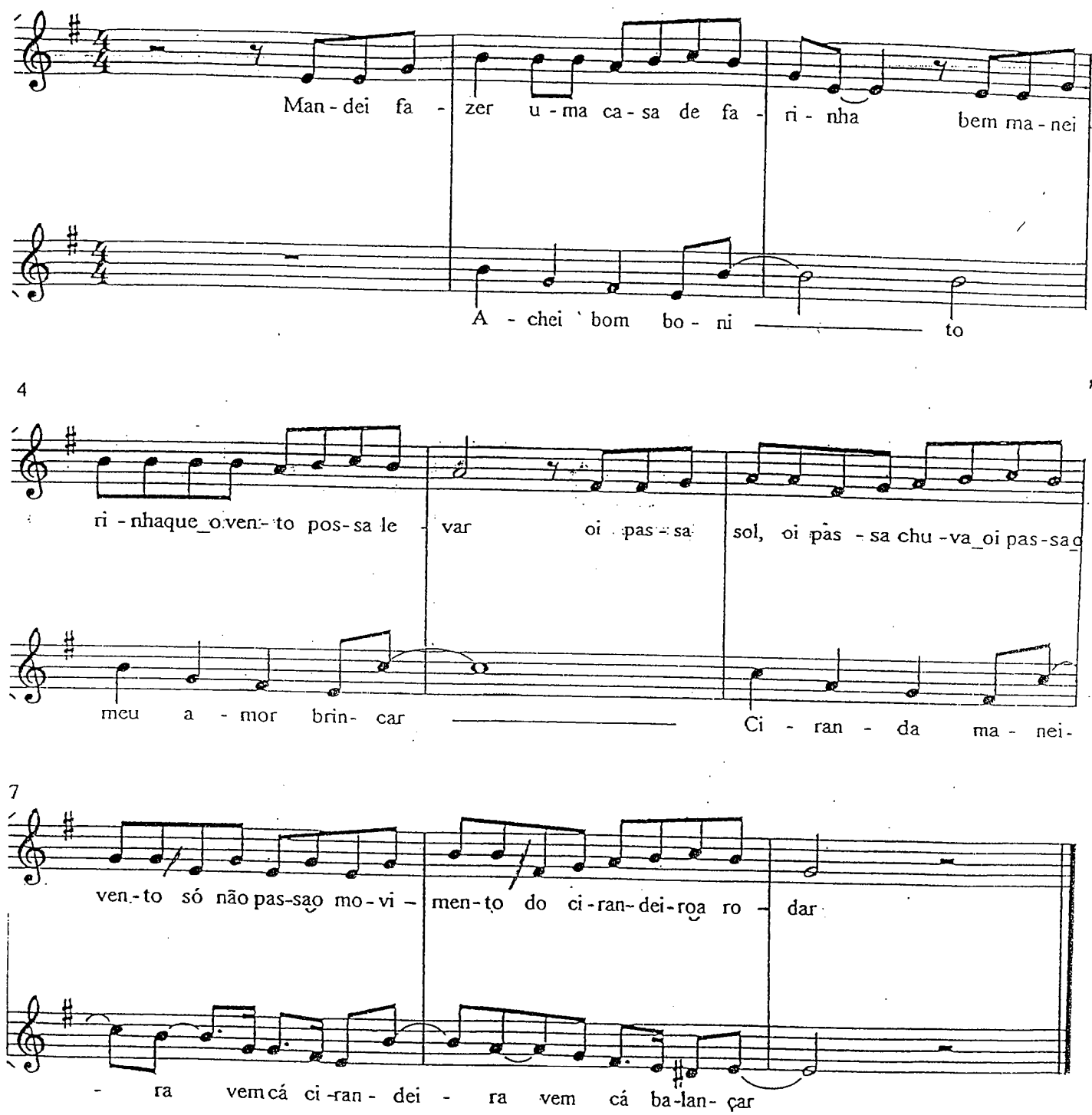

CORAL DA UATU/MACKENZIE 


\section{Canten Señores Cantores}

Argentina Arr. Antonio Russo
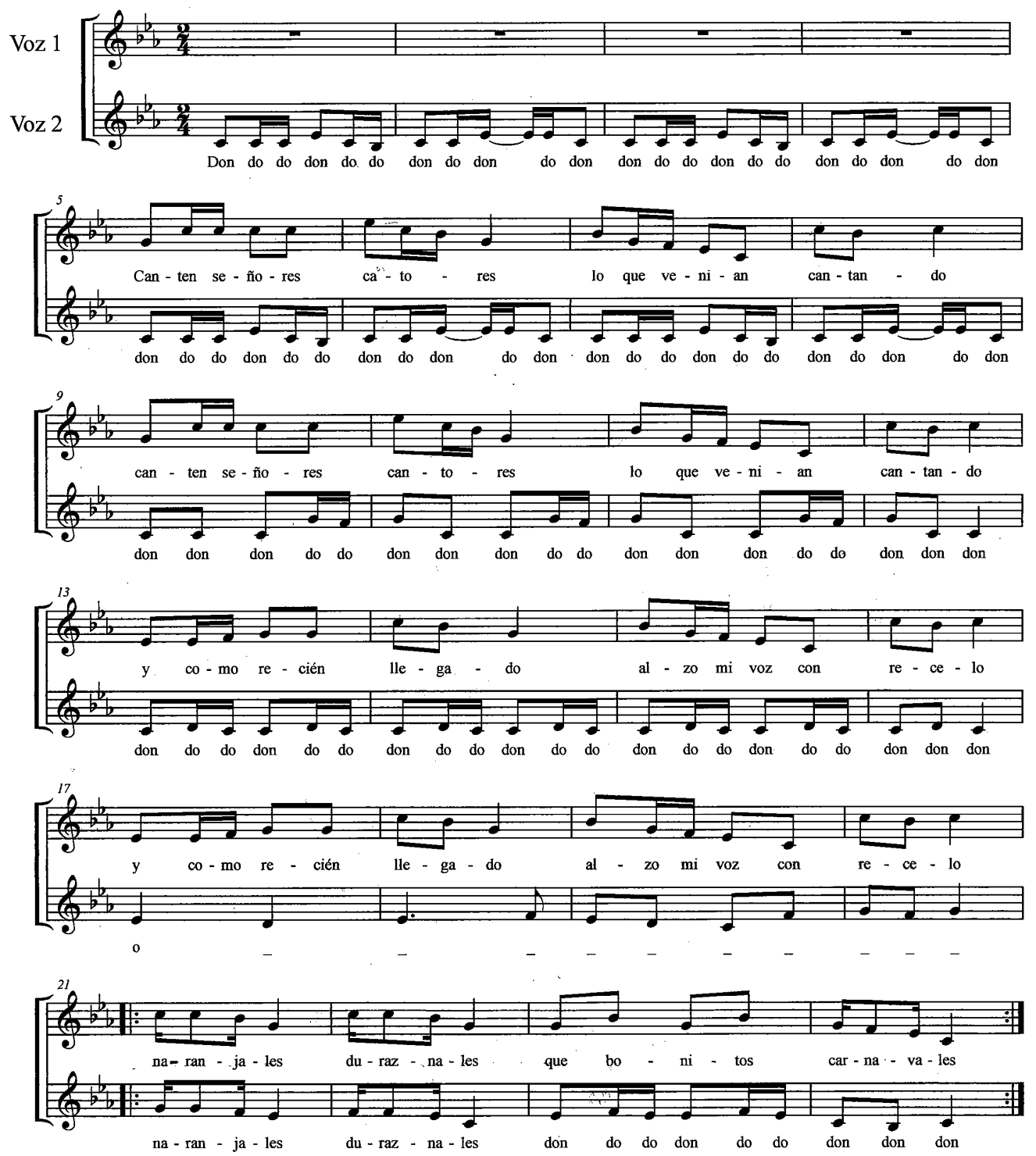

Editoração: Mácio Ocon 

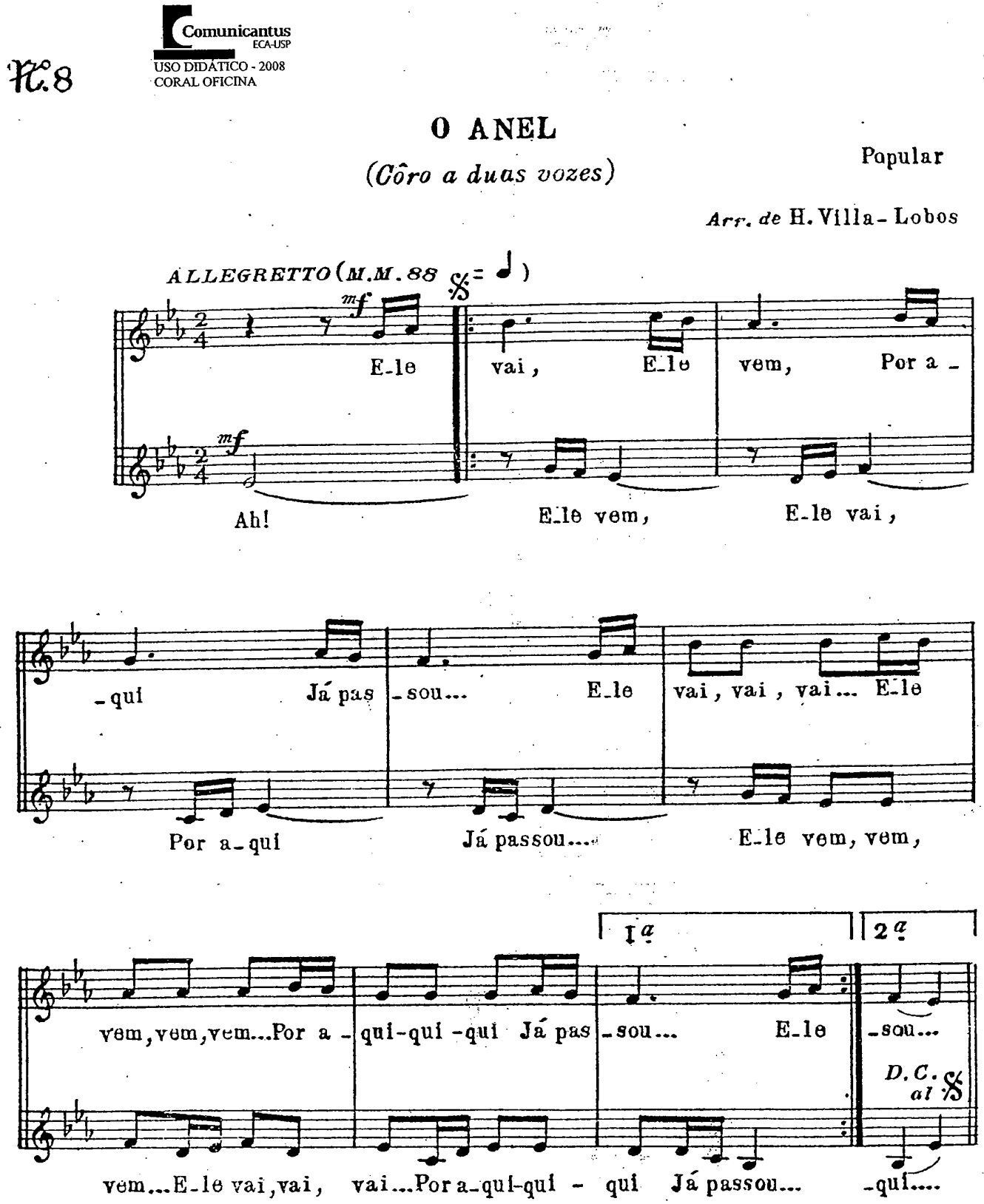

Quando tocada zo Plano, toda a parte da mão esquerda deve ser exeoutada uma olt ava abalxo.

(C) Copyright U. S. A. 1941-by H. Villa-Lobos MARIO, Gravador 
Cuca burra

(cânone)
Comunicantus USO DIDÁTICO - 2008 CORAL OFICINA

(A)

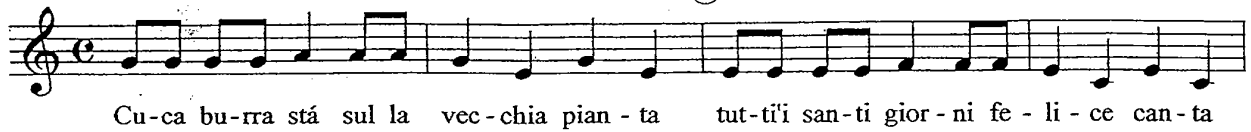

(B)

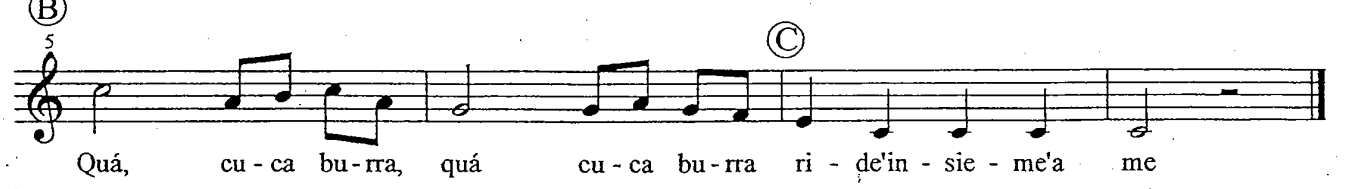

Cuca bu rra stá sul la vecchia pianta

Tutti i santi giorni felice canta

Quá, cuca burra, quá

Cuca burra ride insieme a me 
61. Minno amor, dexiste ay.

Anónimo
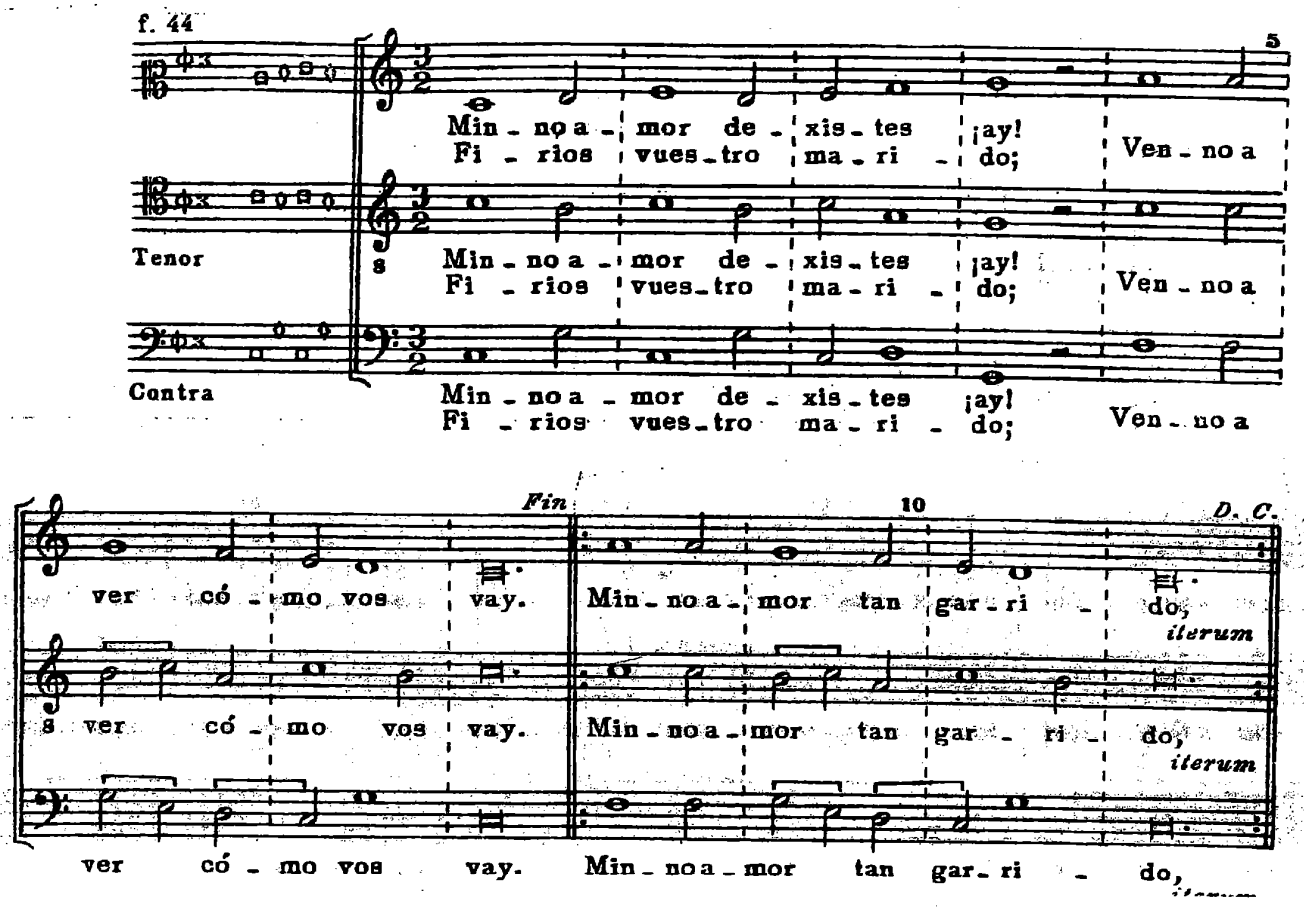

Minno amor dexistes ay!

Venno a ver cómo vos vay.

(2x) Minno amor tan garrido,

Firios vuestro marido;

Venno a ver cómo vos vay.

(2x) Minno amor tan lozano

Firios vuestro velado;

Venno a ver cómo vos vay.

$$
\text { (Cancioneine de Palacion) }
$$




\section{Tres morillas m'enamoran}
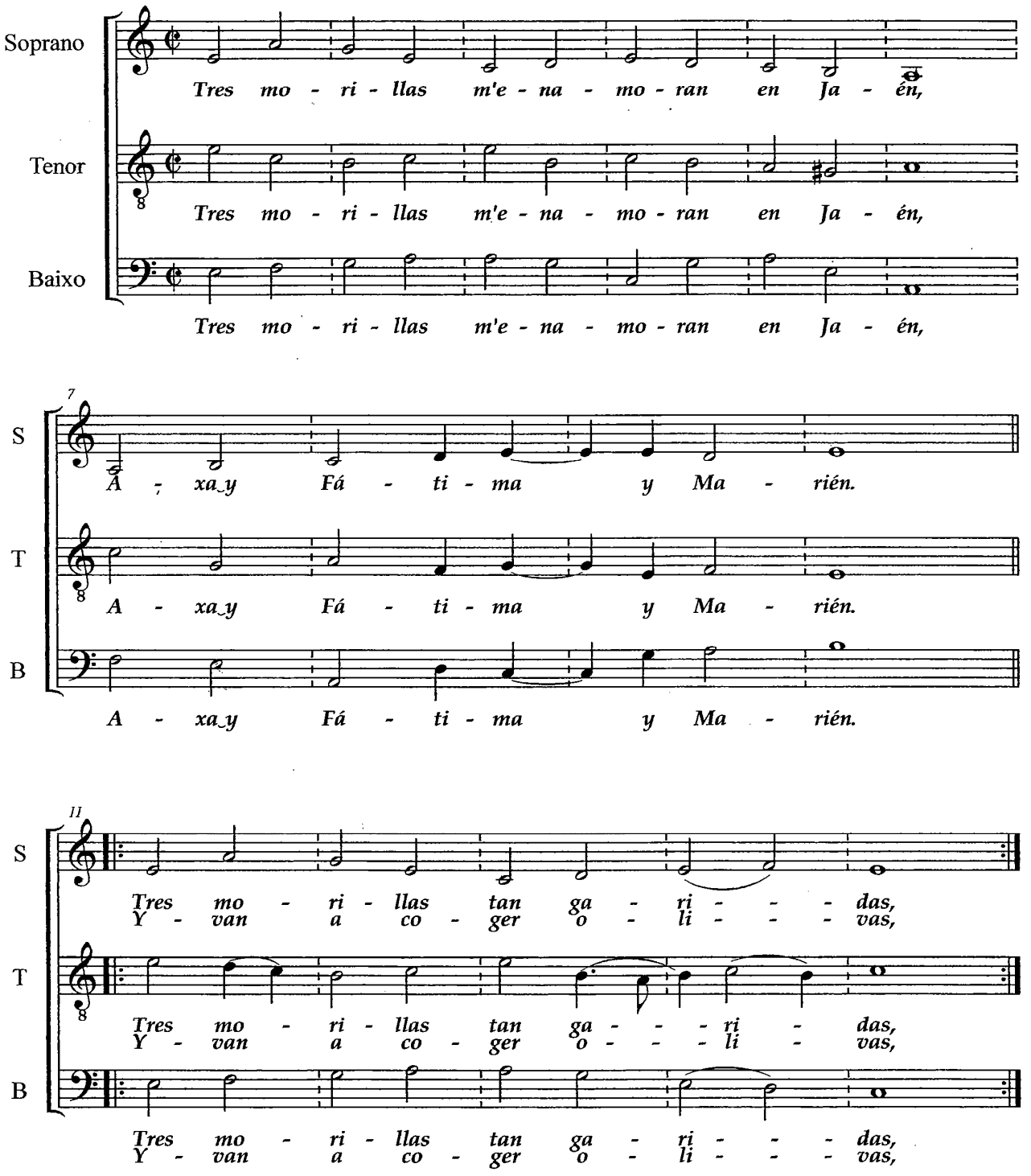

Transcrição: Márcio Ocon

Comunicantus: Laboratório Coral 

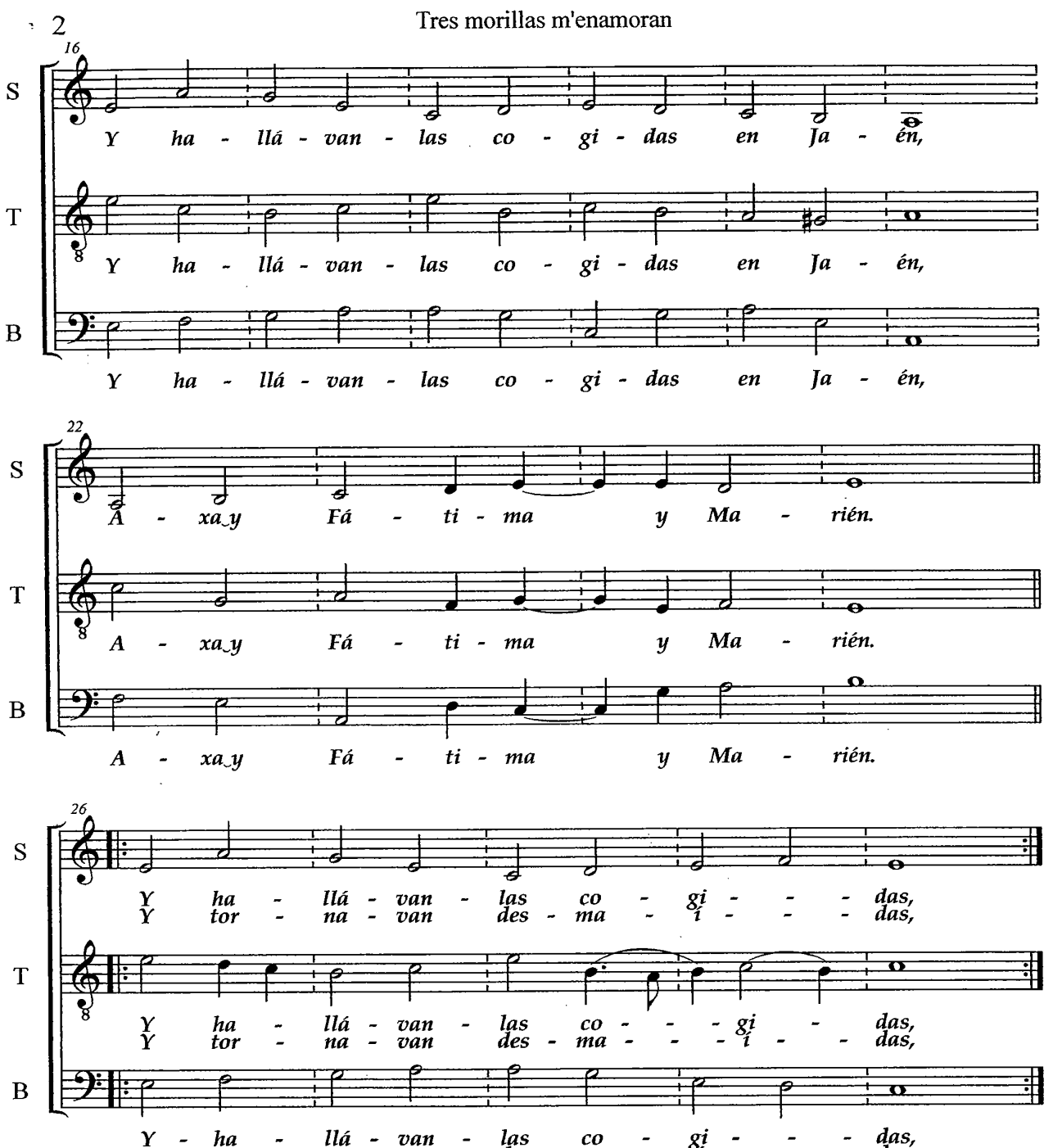

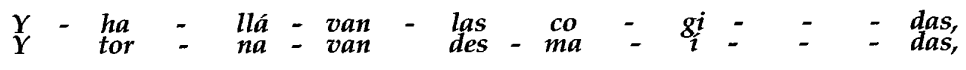

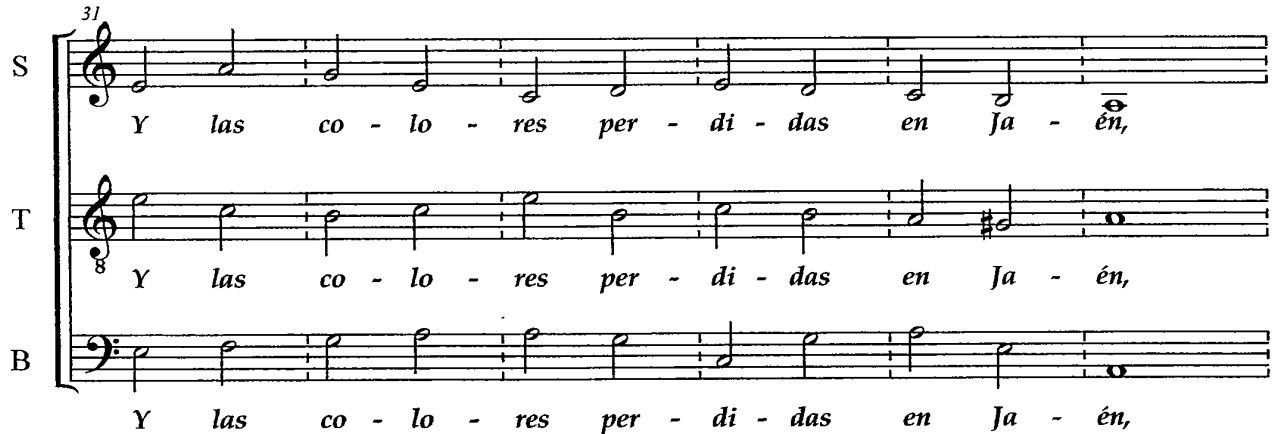



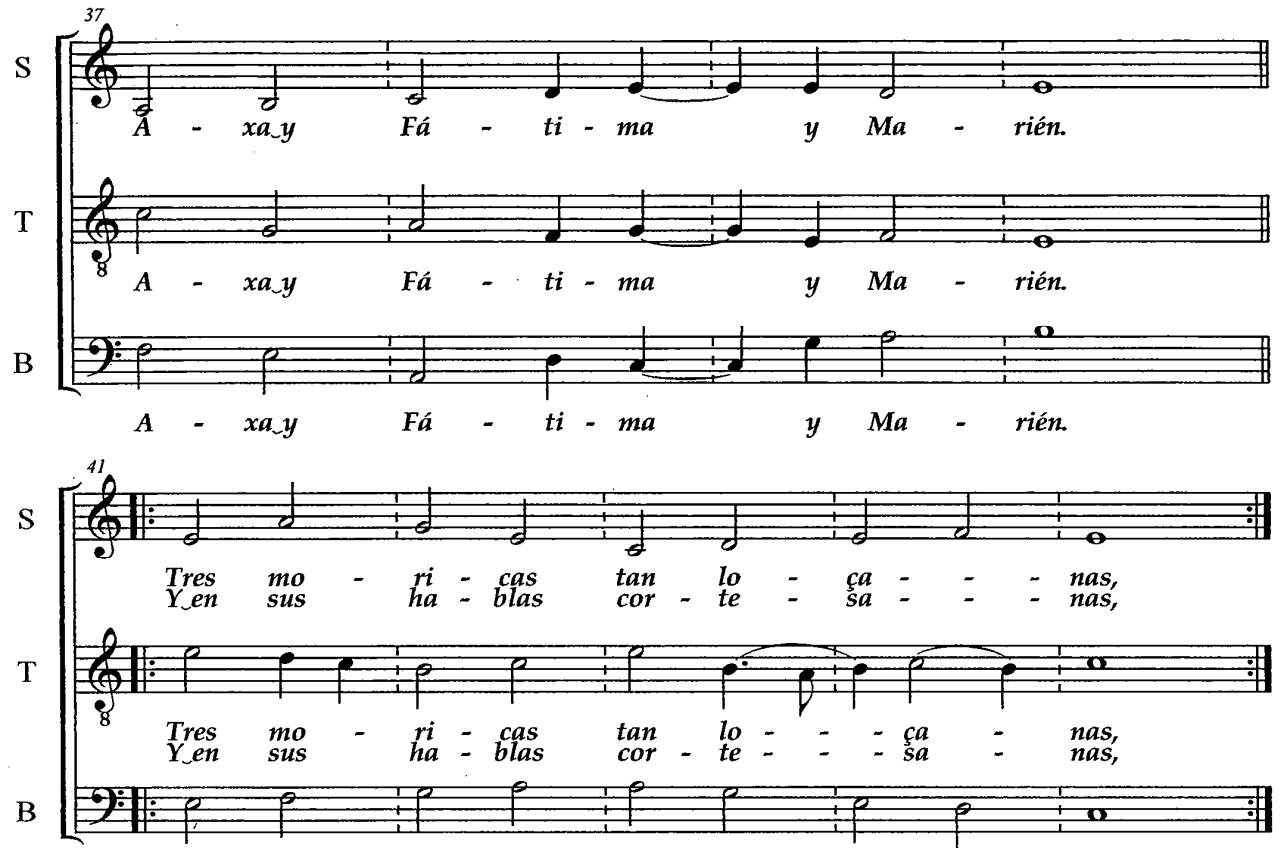

Tres
Yen
sus

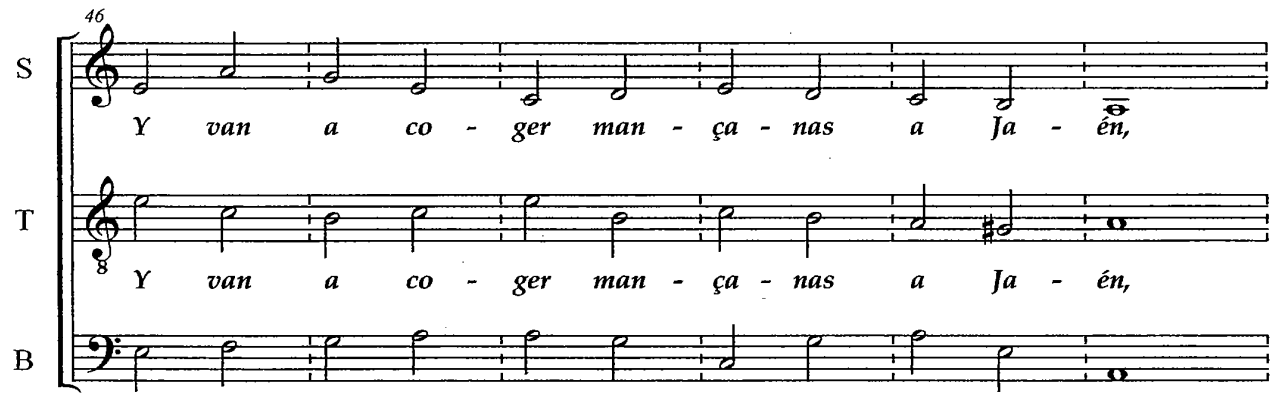

Y va $a$ co - ger man - ça-nas a Ja - én,

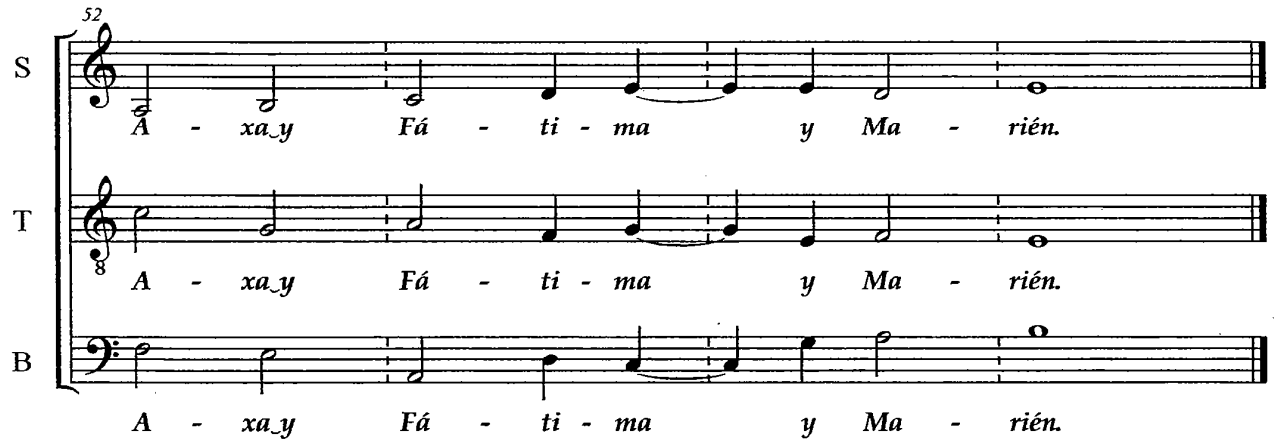




\section{EI Ciodo del Ferro Vecio}

Tradicional do Veneto
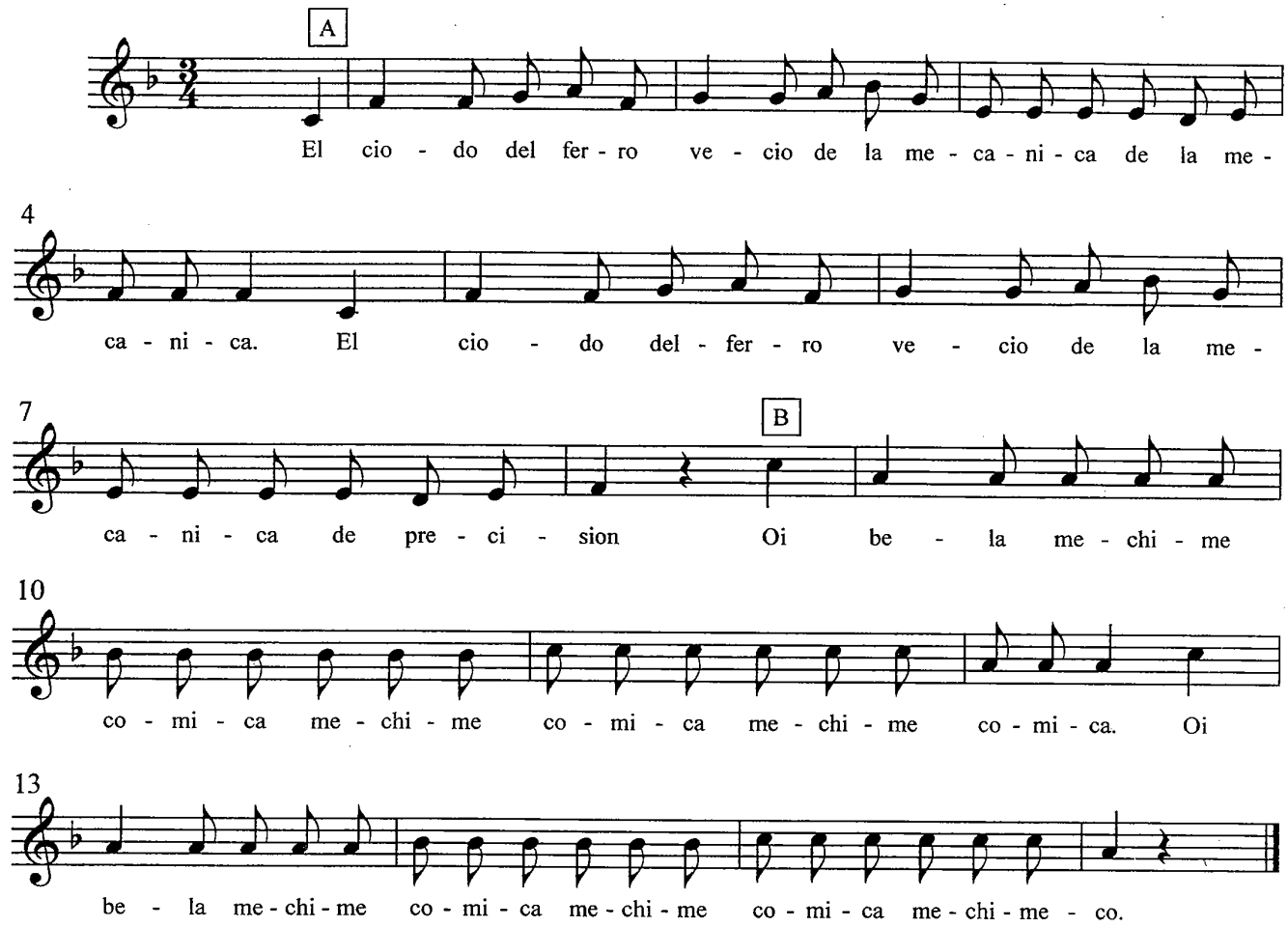

Do livro "Oggi si canta"

Susan Lovegrove Graziano 


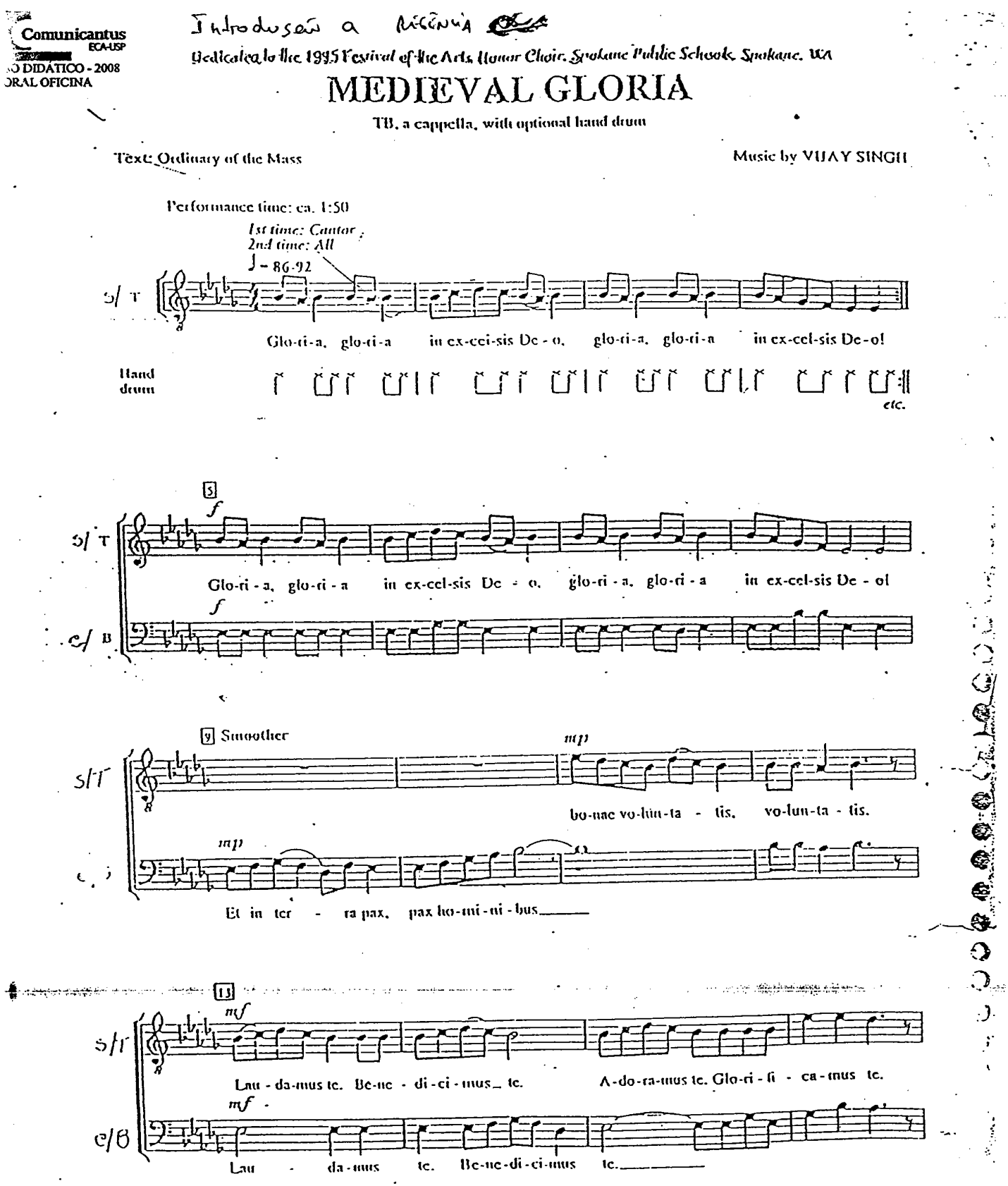




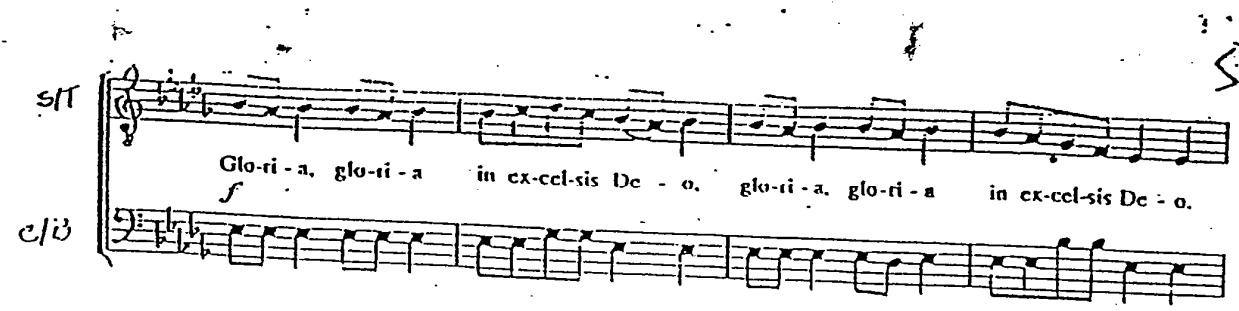

57
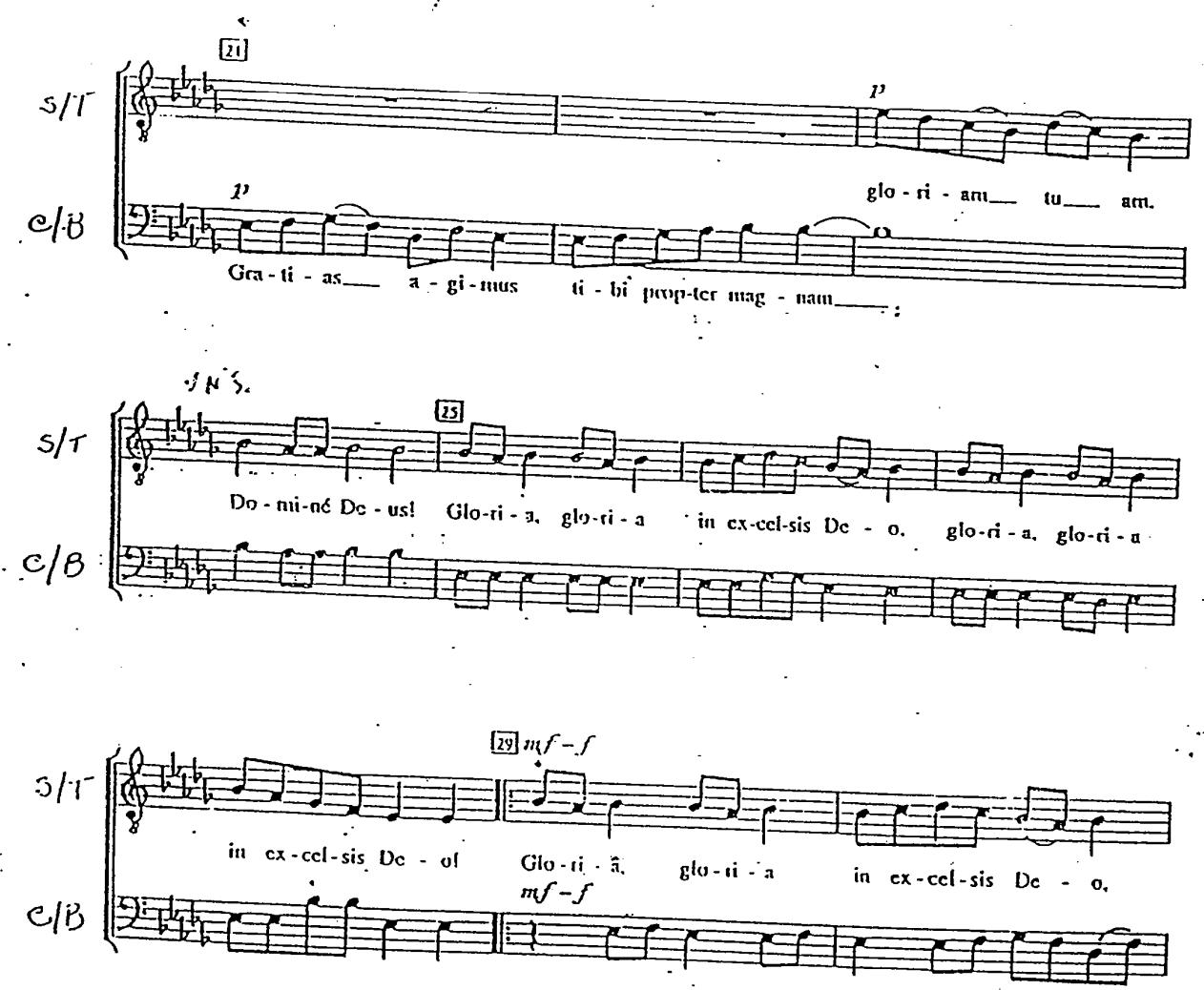

Glo-ri-a. glo-ri - a , in ex-cel-sis De :-

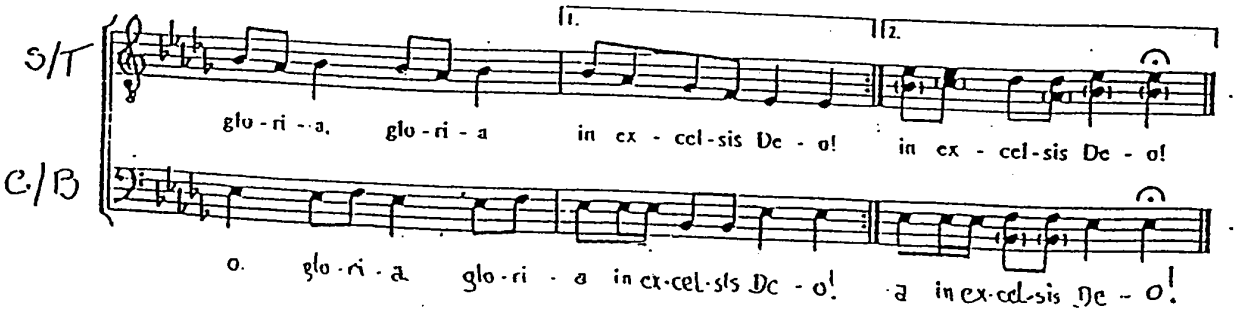




\section{VIVA LA MUSICA}

Camon a 3 voces

MICHAEL PRAETORIUS

(1571 Turingia, Alemania - 1621)
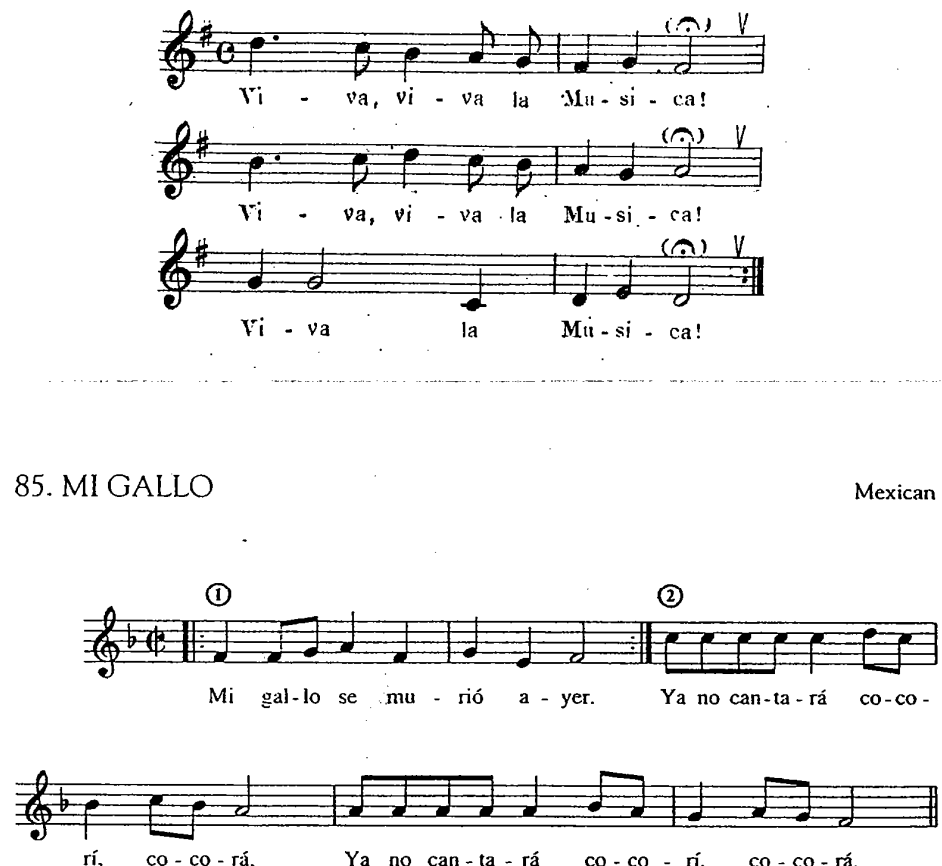

(3)

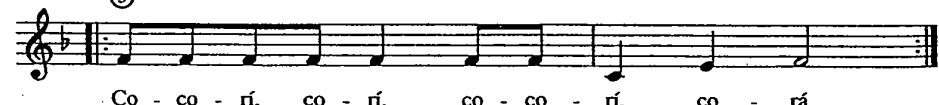

Translation: My rooster died yesterday. He no longer cries, "Cock-a-doodle doo."

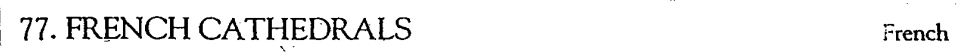

(1)

(2)

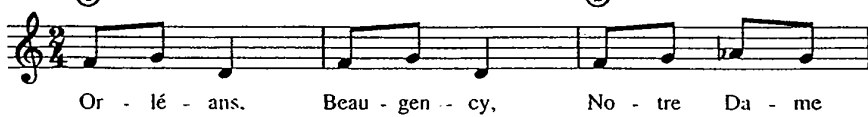

(3)

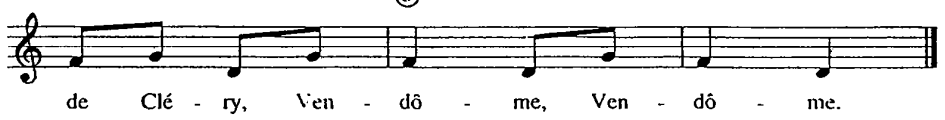

Note: This round comes from the medieval carillon of Vendôme. It names the French tow'ns that Joan of Arc (known as the Maid of Orléans) was to rescue from the English army during the fifteenth century. 

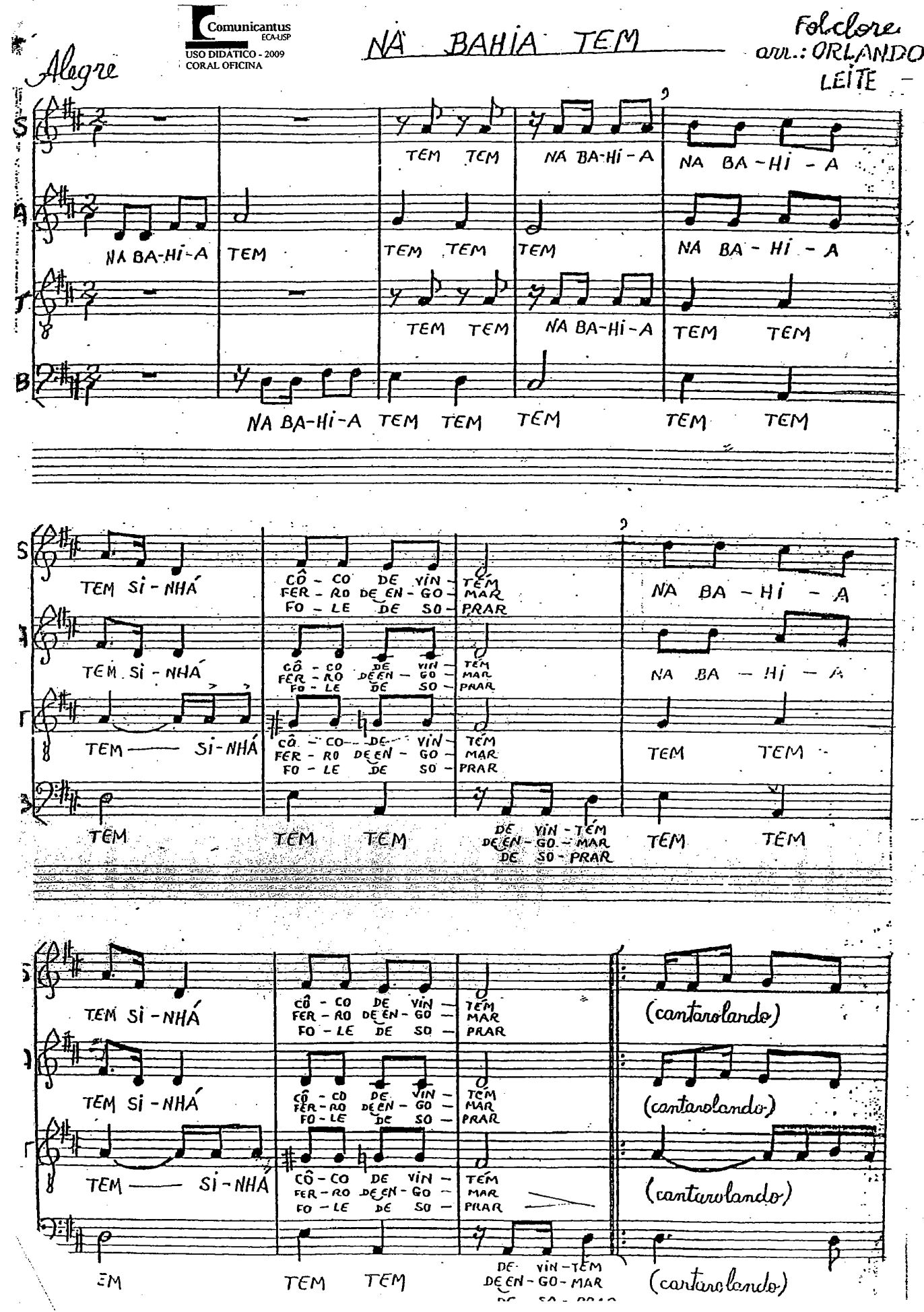


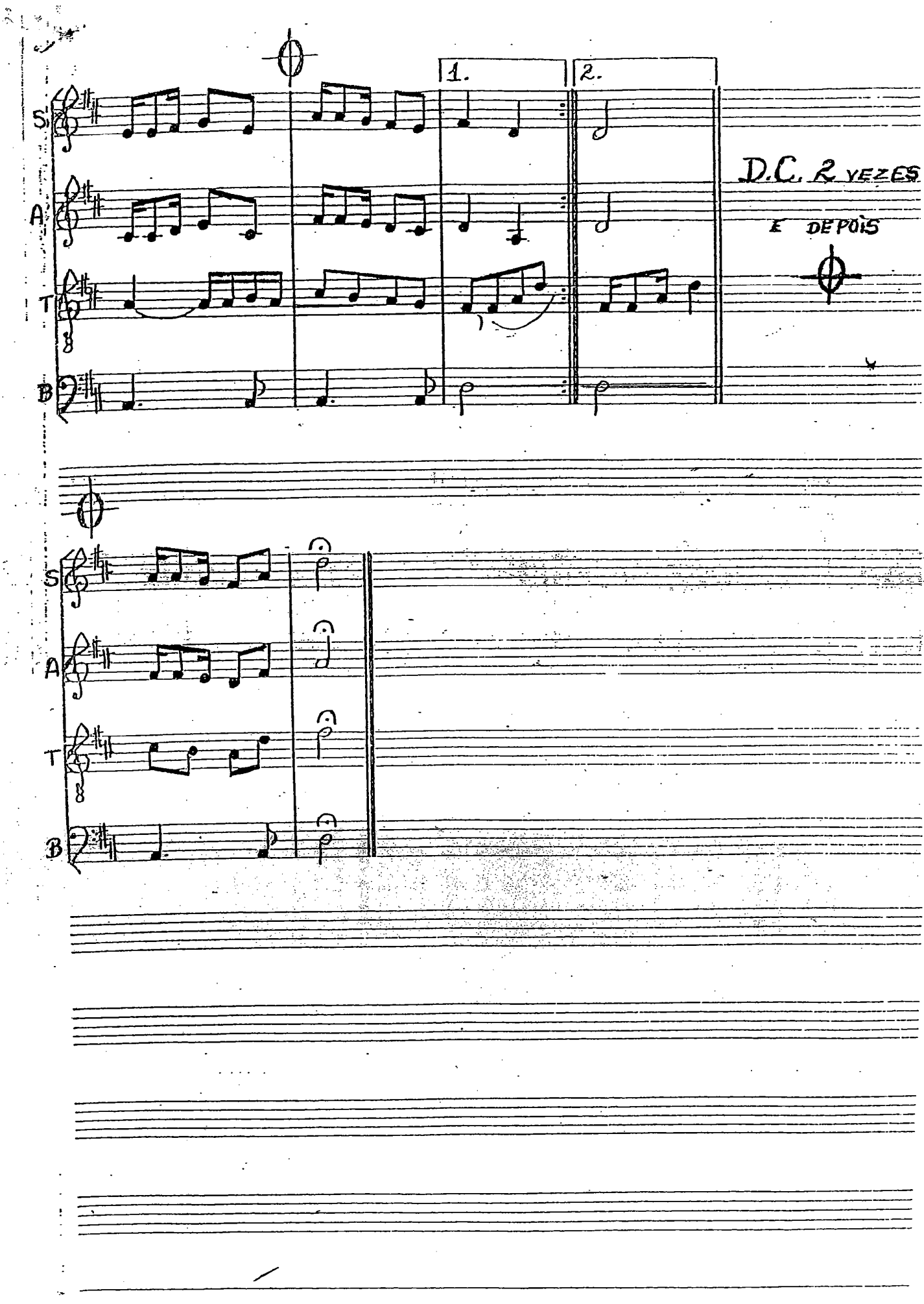


Comunicantus

COPIDATCO- 2009

SO DIDATICU- 2009

Ponta de Areia

Milton Nascimento e F. Brant

Árranjo: Marisa Ramires e

Antonio Carlos Neves Pinto
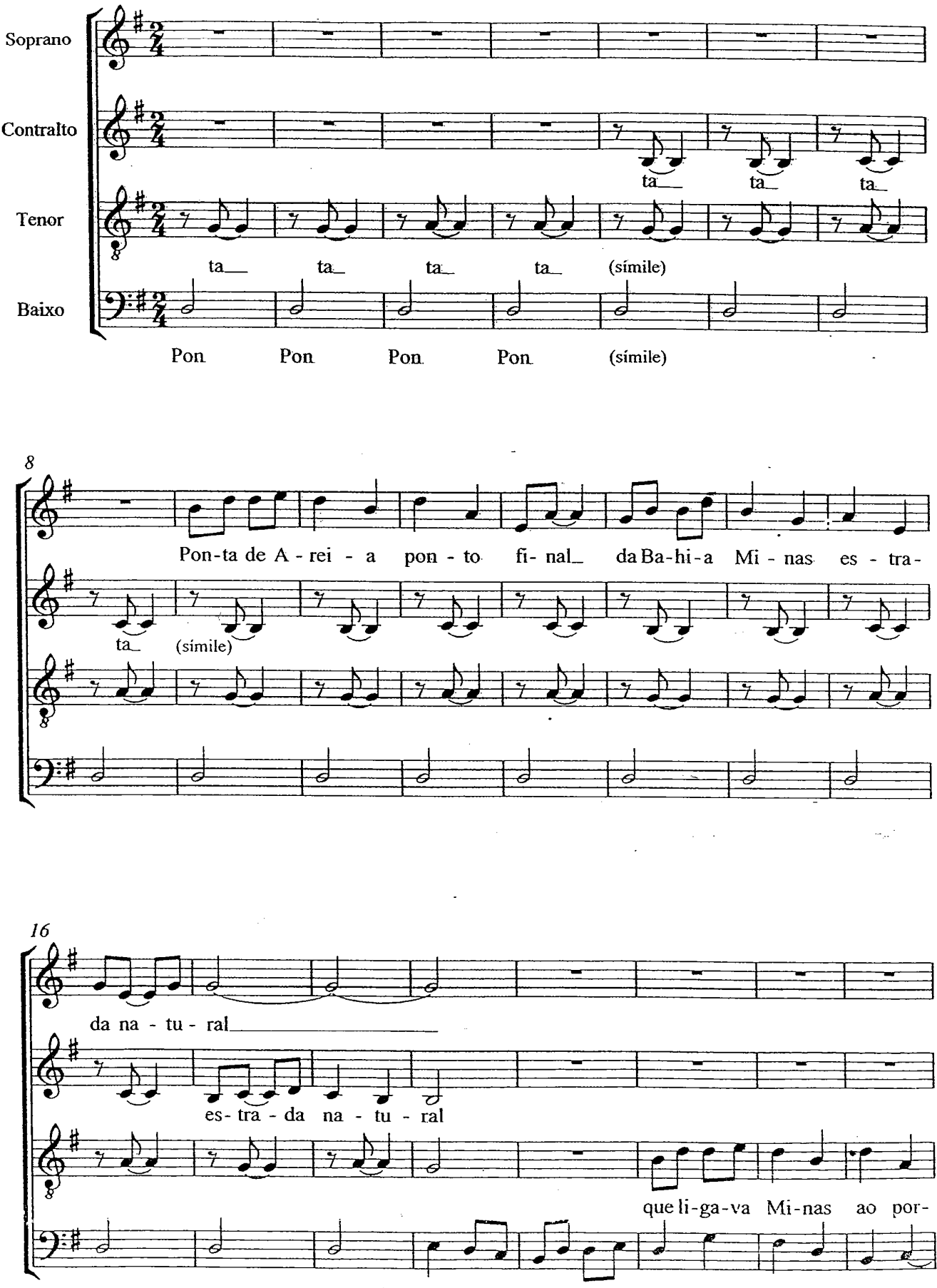
2
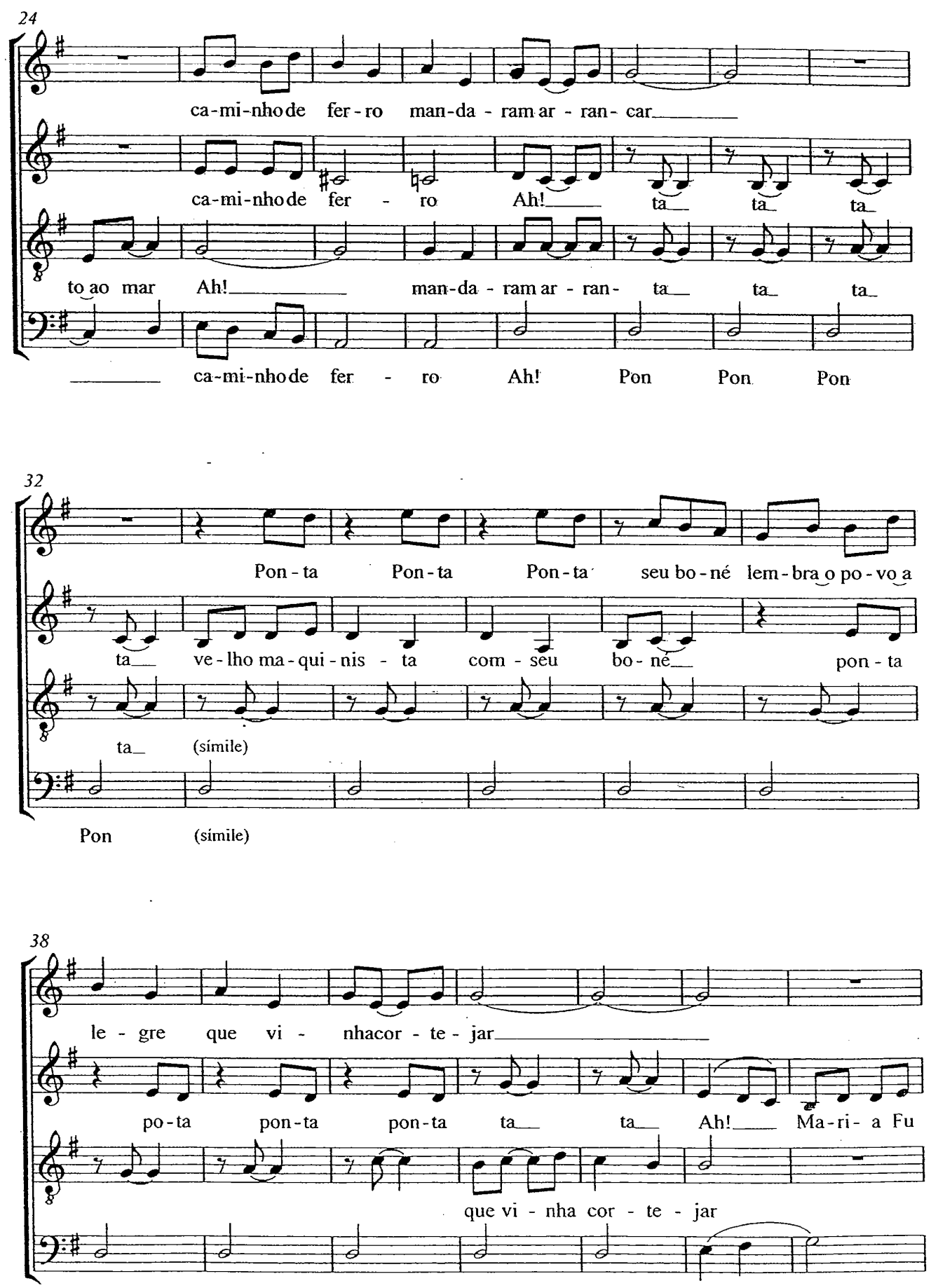

Ah! 

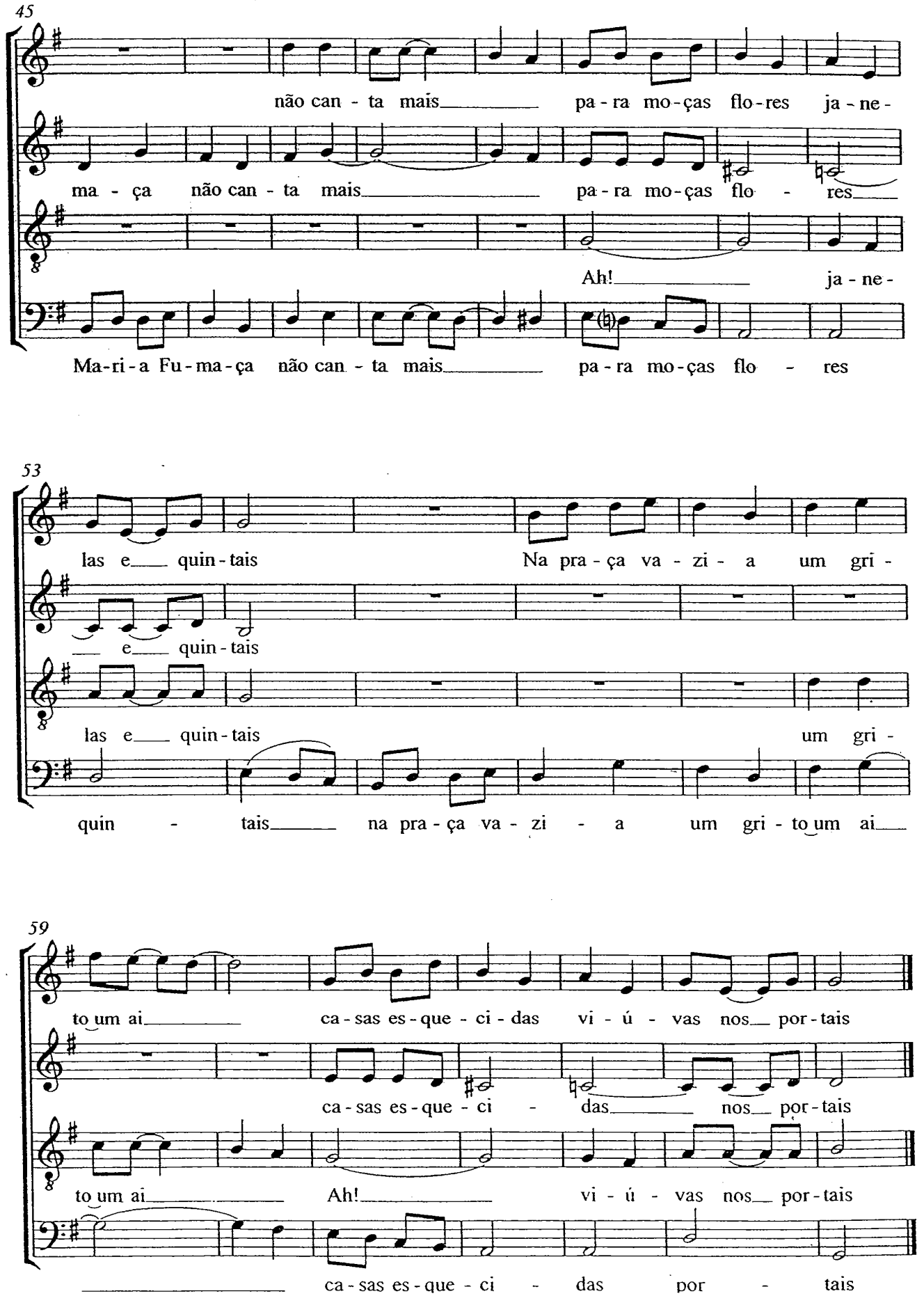


\section{Rodrigo Martines}
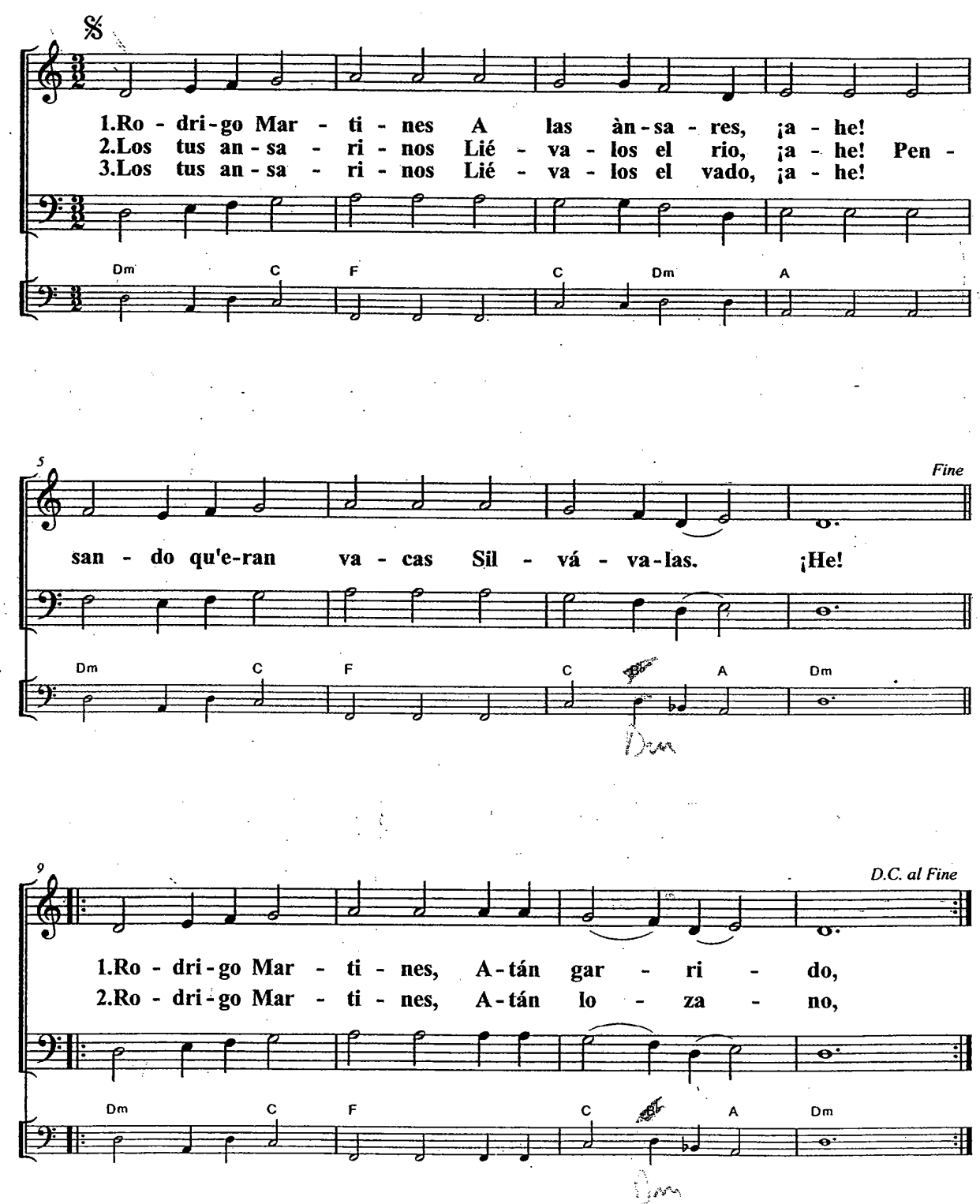

Comunicantus Laboratório Coral Edição: Filipe Fonseca 


\section{$0 L-565$}

-3-

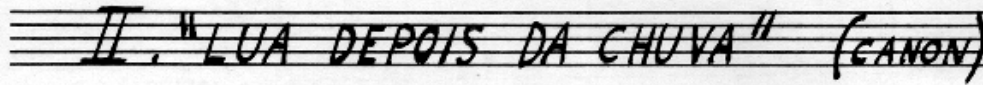

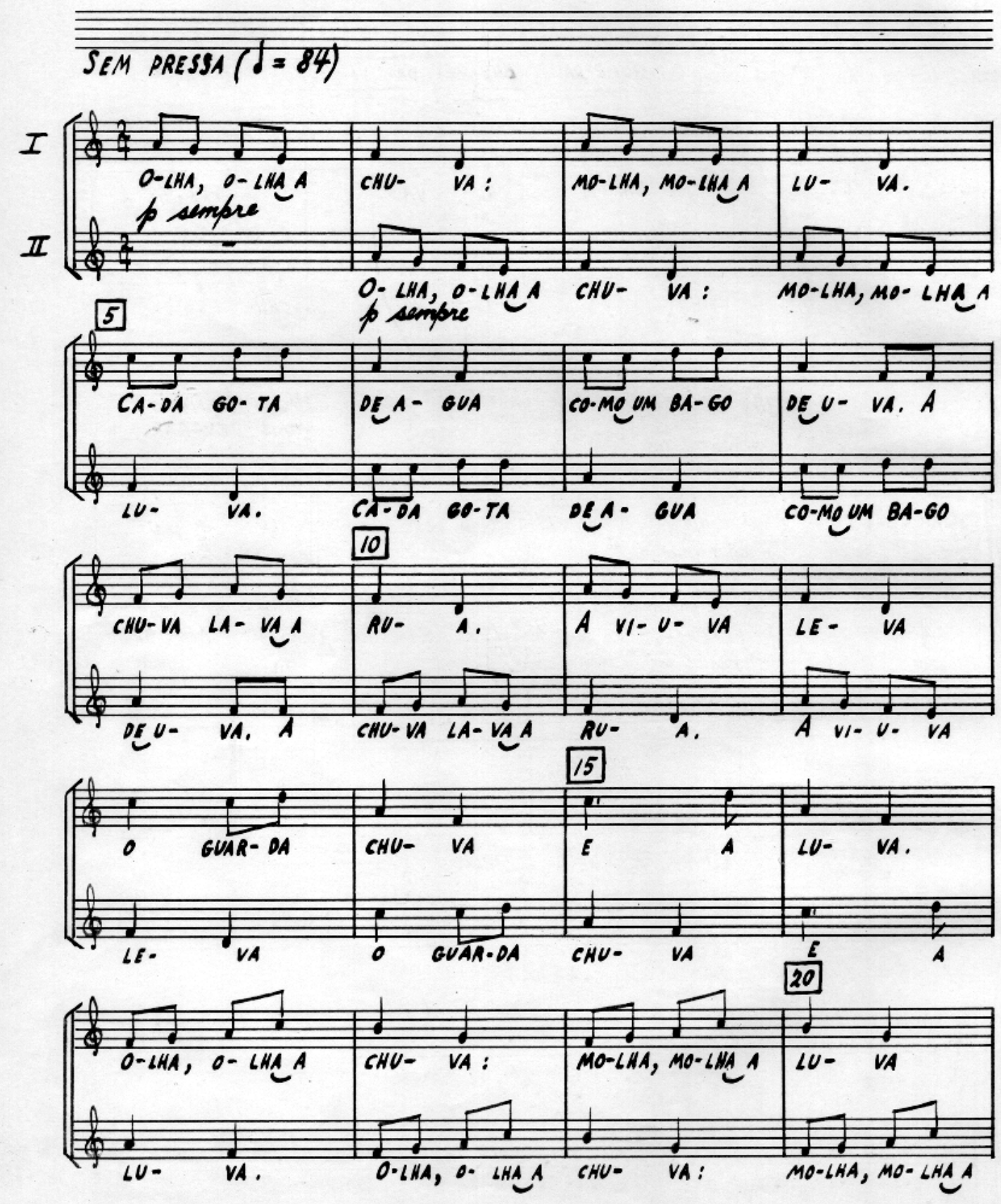


06.565

$$
-4
$$
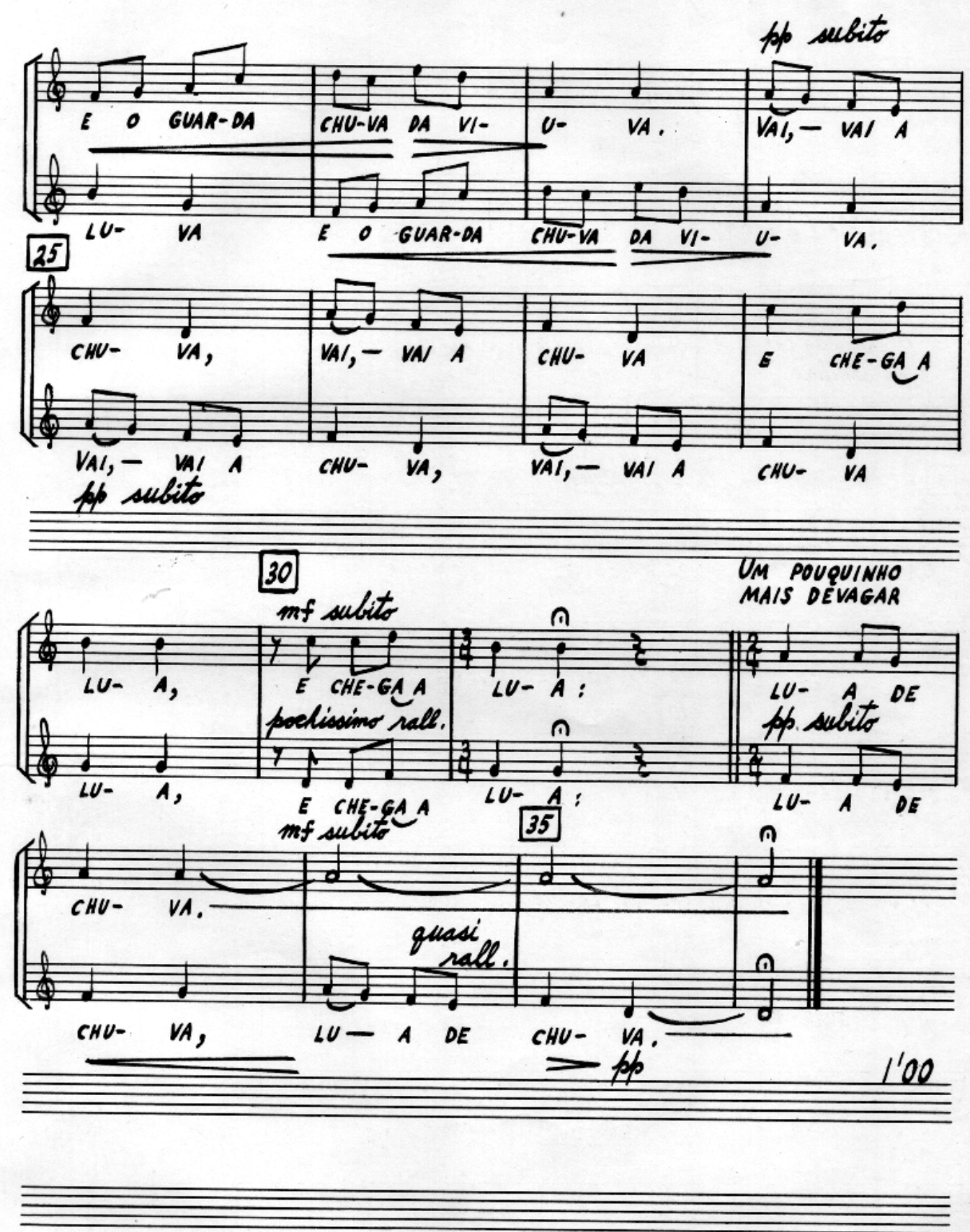
ANEXO B 


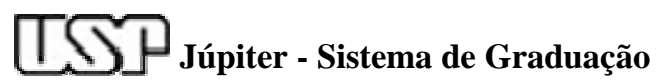

Escola de Comunicações e Artes

\author{
Música \\ Disciplina: CMU0508 - Práticas Multidisciplinares em Canto Coral, com Estágio Supervisionado I, II, \\ III, IV, V e VI

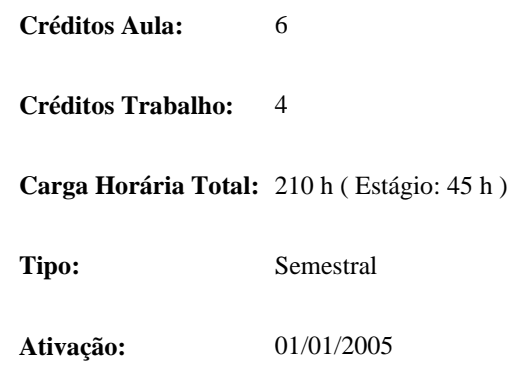

\title{
Objetivos
}

1.Oferecer aos alunos do conjunto de disciplinas atinentes à regência Coral do CMU um espaço de prática supervisionada nos campos da regência, técnica vocal , educação musical, pesquisa, escolha, preparação e literatura de repertório coral, composição e arranjo para canto coral;2.Criar Condições objetivas e práticas para a profissionalização do estudante;3.Integrar o conhecimento musical adquirido nas demais disciplinas oferecidas na graduação através de vivência em canto coral, no interior do LAC;4.Permitir ao estudante a efetiva aplicação de seus conhecimentos no âmbito do Coral Escola Comunicantus e do Coral da Terceira Idade da USP;

\section{Docente(s) Responsável(eis)}

74427 - Marco Antonio da Silva Ramos

2021713 - Susana Cecilia Almeida Igayara de Souza 


\section{Programa Resumido}

1.Estágio no Coral Escola Comunicantus e no Coral da Terceira Idade da USP sob supervisão do Prof. de Regência Coral do CMU;2.O estágio será supervisionado nas áreas de regência, técnica vocal , educação musical, pesquisa, escolha, preparação e literatura de repertório coral, composição e arranjo para canto coral;

\section{Programa}

1.Estágio no Coral Escola Comunicantus e no Coral da Terceira Idade da USP sob supervisão do Prof. de Regência Coral do CMU;2.O estágio será supervisionado nas áreas de regência, técnica vocal , educação musical, pesquisa, escolha, preparação e literatura de repertório coral, composição e arranjo para canto coral;

\section{Avaliação}

\section{Método}

Prática e planejamento supervisionados nas áreas descritas no ìtem 14OBS: o aluno deverá, para sua aceitação de matrícula, apresentar previamente ao professor responsável um PLANO DE ESTÁGIO, que o analisará e indicará à Secretária de Graduação do CMU a relação dos alunos aceitos no semestre.

\section{Critério}

Serão avaliados o envolvimento e a eficácia do estudante em sua relação com seu projeto de estágio, além de sua efetiva performance nas funções que exerceu no decorrer do estágio

\section{Norma de Recuperação}

Não será oferecida por motivos operacionais, de acordo com a resolução COG-3583, Art. $3^{\circ}$, Parágrafo $1^{\circ}$, de 29.09.89. 


\section{Bibliografia}

BAKALEINIKOFF, Vladimir. Elementary Rules of Conducting. Belwin Inc. New York, 1938.CORTOT, Alfred. Curso de interpretação. Editora Musimed, Brasília, 1986.CROWTHER, Duane. Teaching Choral Concepts. Horizon Pub. And Distr., West Bountiful,1981.DART, Thurston. Interpretação da Música. Martins Fontes, São Paulo, 1990.GALLO, José Antonio, GRAETZER, Guillermo, NARDI, Héctor y RUSSO, Antonio. El Director de Coro. Ricordi Americana, Buenos Aires, 1979GARRETSON, Robert L. Conducting Choral Music. 7a Ed. Prentice Hall, Nmew Jersey, 1993.HARNONKOURT, Nikolaus. O Discurso dos Sons. Jorge Zahar Editor, Rio de Janeiro, 1988.HOLODENKO, Ilia. La Chorale Populaire. Editions Sociales,Paris, 1950.JAFFERS, John. Translations and Annotations of Choral Repertoire. (v.1) - Sacred Latin Textes. Corvallis, Earthsongs, 1988.LEBRECHT, Norman. O mito do maestro. Civilização Brasileira, Rio de janeiro, 2002RAMOS, Marco Antonio da Silva Ramos. Canto Coral: do repertório temático à construção do programa. Dissertação de Mestrado apresentada à ECA-USP, 1989.O ensino da Regência Coral. Tese de Livre Docência apresentada à ECA-USP, 2003.ROBINSON, Ray e WINOLD, Allen. The Choral experience. Harper and Row,Publishers, New York, London, 1976. SALAZAR, Adolfo. Sinfonia y Ballet - Idea y Gesto en la musica contemporânea. $1^{\circ}$ ed. Editorial Mundo Latino, Madrid, 1929.SCHAEFER, R. Murray. A Afinação do Mundo. Ed. UNESP, São Paulo, 2001.SCHÖNBERG, Arnold. Fundamentals of Music Composition. Faber and Faber, London, 1983. Style and Idea. St. Martin Press, New York, s/d.STRUNK, Oliver. Source Readings in Music History. (v. 3 - The Baroque Era). W.W. Norton \& Company Inc, New York, s/d. 